\title{
Feasibility Study for Remedial Action for the Quarry Residuals Operable Unit at the Weldon Spring Site, Weldon Spring, Missouri
}

March 1998

prepared by

Environmental Assessment Division, Argonne National Laboratory

\section{prepared for}

U.S. Department of Energy, Weldon Spring Site Remedial Action Project, Weldon Spring, Missouri, under Contract W-31-109-Eng-38
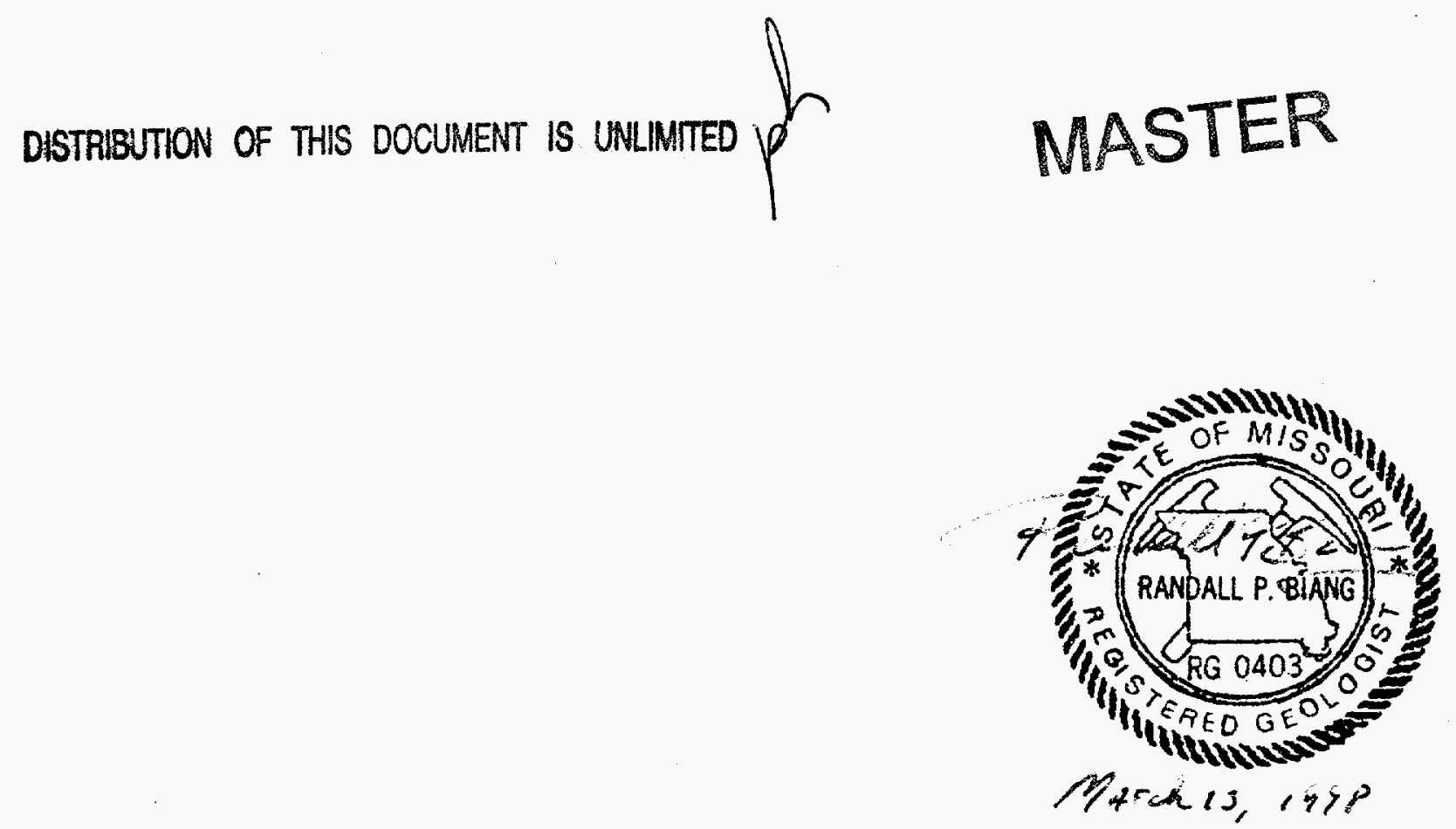


\section{DISCLAMER}

This report was prepared as an account of work sponsored by an agency of the United States Government. Neither the United States Government nor any agency thereof, nor any of their employees, makes any warranty, express or implied, or assumes any legal liability or responsibility for the accuracy, completeness, or usefulness of any information, apparatus, product, or process disclosed, or represents that its use would not infringe privately owned rights. Reference herein to any specific commercial product, process, or service by trade name, trademark, manufacturer, or otherwise does not necessarily constitute or imply its endorsement, recommendation, or favoring by the United States Government or any agency thereof. The views and opinions of authors expressed herein do not necessarily state or reflect those of the United States Government or any agency thereof. 


\section{DISCLAIMER}

Portions of this document may be illegible electronic image products. Images are produced from the best available original document. 


\section{CONTENTS}

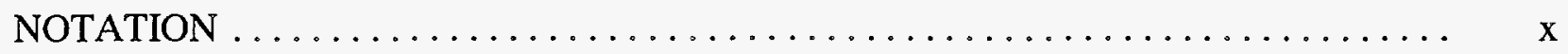

ENGLISH/METRIC AND METRIC/ENGLISH EQUIVALENTS $\ldots \ldots \ldots \ldots \ldots \ldots$ xiii

1 INTRODUCTION ........................................ $1-1$

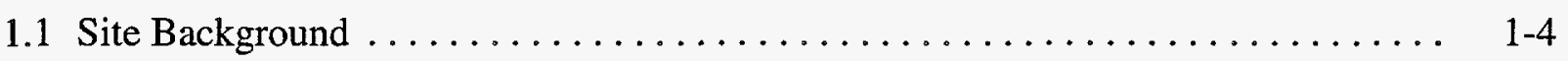

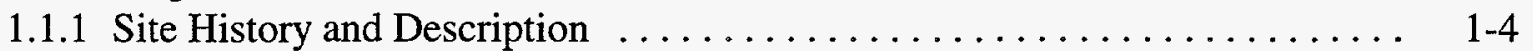

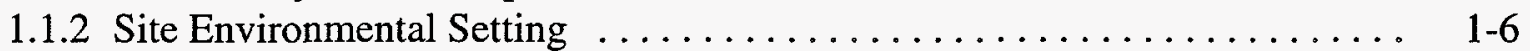

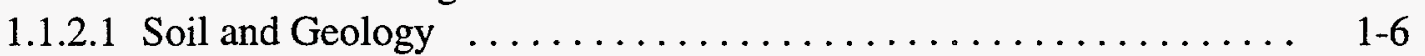

1.1.2.2 Hydrogeology ............................ 1-9

1.1.2.3 Biotic Resources ............................ 1-11

1.1.2.4 Land Use and Demography $\ldots \ldots \ldots \ldots \ldots \ldots \ldots \ldots \ldots \ldots, 1-12$

1.2 Nature and Extent of Contamination $\ldots \ldots \ldots \ldots \ldots \ldots \ldots \ldots \ldots \ldots \ldots \ldots \ldots \ldots \ldots \ldots \ldots, 12$

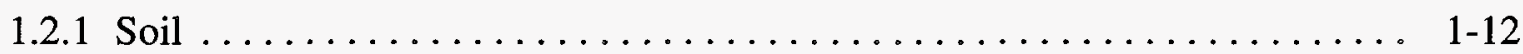

1.2.2 Femme Osage Slough and Creeks $\ldots \ldots \ldots \ldots \ldots \ldots \ldots \ldots \ldots \ldots \ldots, 1-14$

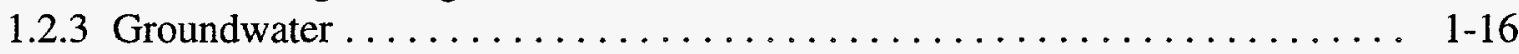

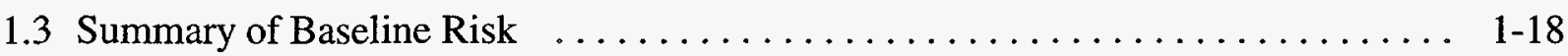

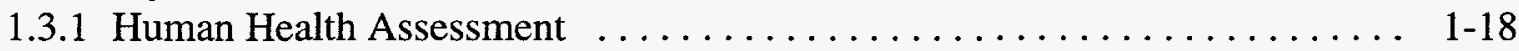

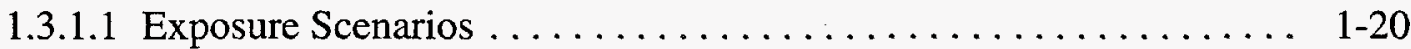

1.3.1.2 Risk Characterization $\ldots \ldots \ldots \ldots \ldots \ldots \ldots \ldots \ldots \ldots \ldots, 1-20$

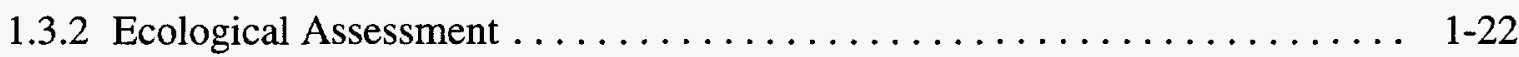

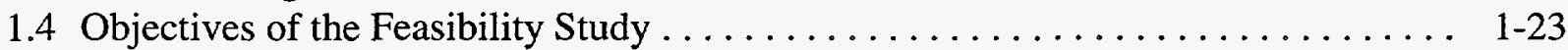

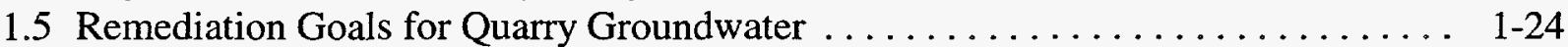

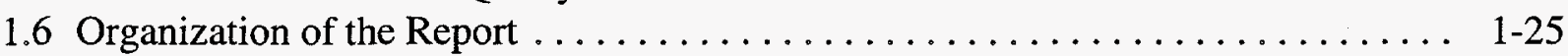

2 IDENTIFICATION AND SCREENING OF TECHNOLOGIES $\ldots \ldots \ldots \ldots \ldots \ldots$

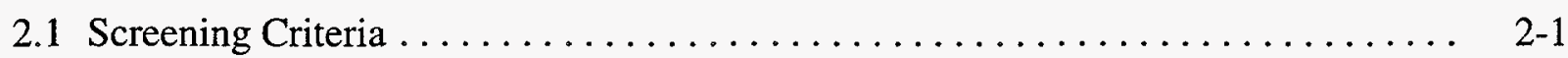

2.2 Technology Identification and Screening $\ldots \ldots \ldots \ldots \ldots \ldots \ldots \ldots \ldots .2-3$

2.2.1 Institutional Controls and Monitoring $\ldots \ldots \ldots \ldots \ldots \ldots \ldots \ldots \ldots .2-3$

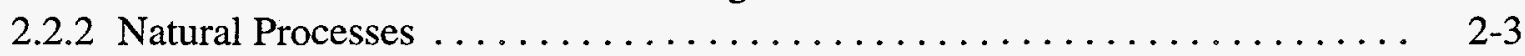

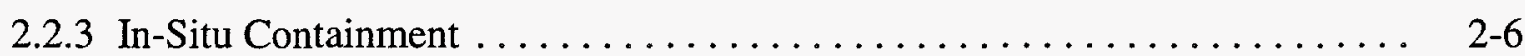

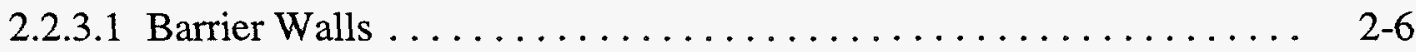

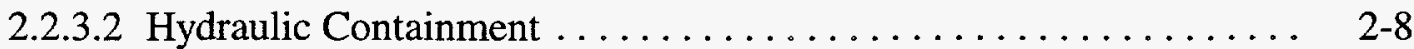

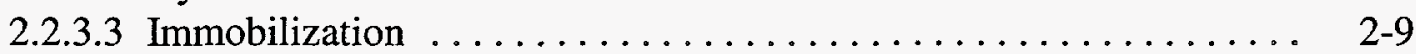

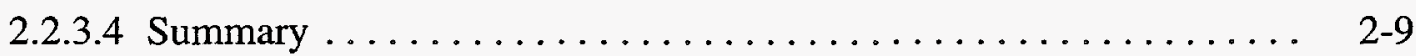

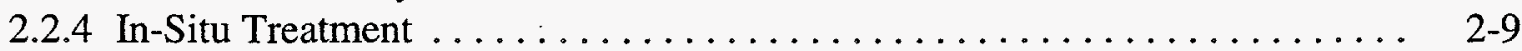

2.2.4.1 Bioremediation $\ldots \ldots \ldots \ldots \ldots \ldots \ldots \ldots \ldots \ldots \ldots \ldots \ldots \ldots \ldots \ldots, 2-10$

2.2.4.2 Electrokinetics .............................. 2-10

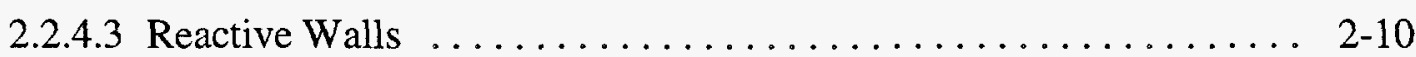

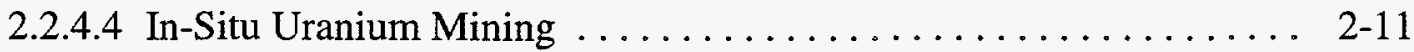




\section{CONTENTS (Cont.)}

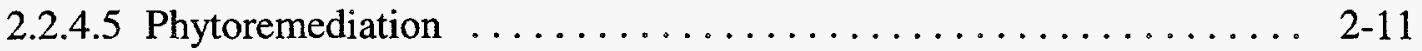

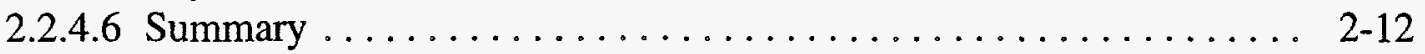

2.2.5 Removal of Groundwater from the Aquifer . . . . . . . . . . . . . . 2-13

2.2.5.1 Vertical Wells ........................... 2-13

2.2.5.2 Horizontal Wells ........................ 2-13

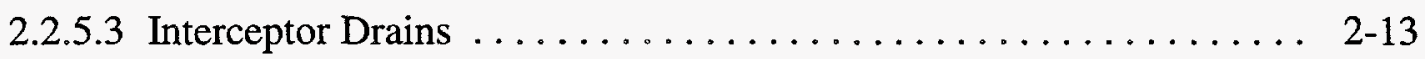

2.2.5.4 Excavation ............................ 2-14

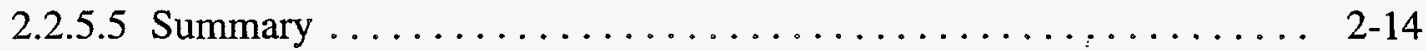

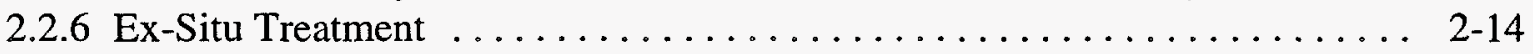

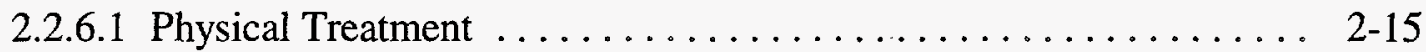

2.2.6.2 Chemical/Physical Treatments ................... 2-16

2.2.6.3 Biological/Physical Treatments ................... 2-19

2.2 .6 .4 Summary . . . . . . . . . . . . . . . . . . . . . . 2 2 .

2.2 .7 Disposal . . . . . . . . . . . . . . . . . . . . . . . . 2-19

2.3 Potentially Applicable Technologies $\ldots \ldots \ldots \ldots \ldots \ldots \ldots \ldots \ldots \ldots \ldots \ldots$. . . . . . . . . . .

3 DEVELOPMENT AND SCREENING OF PRELIMINARY ALTERNATIVES . . . . 3-1

3.1 Criteria for Developing Alternatives $\ldots \ldots \ldots \ldots \ldots \ldots \ldots \ldots \ldots \ldots \ldots \ldots$

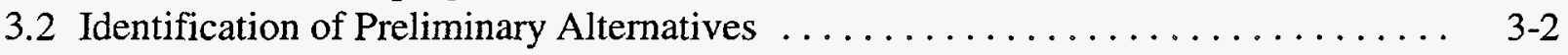

3.2.1 Factors Common to Preliminary Action Alternatives $\ldots \ldots \ldots \ldots \ldots \ldots$ 3-2

3.2.2 Factors Specific to Each Preliminary Alternative ..... . . . . . . . . . 3-3

3.2.2.1 Alternative 1 . No Action .................... 3-3

3.2.2.2 Alternative 2: Monitoring with No Active Remediation . . . . . . 3-3

3.2.2.3 Alternative 3: Groundwater Removal with On-Site Treatment .... 3-6

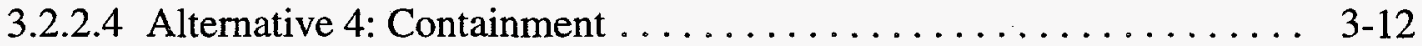

3.2.2.5 Alternative 5: In-Situ Treatment Using Permeable Barriers . . . . . . 3-15

3.2.2.6 Alternative 6: Groundwater Removal at Selected Areas, with On-Site Treatment ..................... . . 3-19

3.3 Criteria for Screening Alternatives . . . . . . . . . . . . . . . . . . . . . 3-26

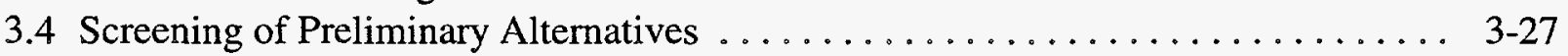

3.4.1 Alternative 1 : No Action $\ldots \ldots \ldots \ldots \ldots \ldots \ldots \ldots \ldots \ldots \ldots \ldots \ldots \ldots \ldots$

3.4.1.1 Effectiveness . . . . . . . . . . . . . . . . . . . . . . 3-27

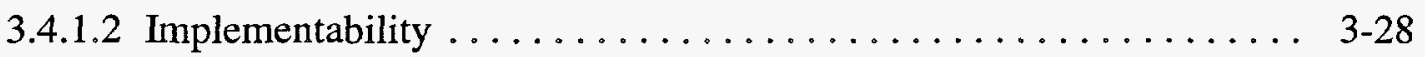

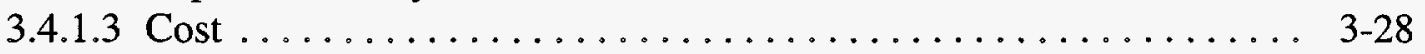

3.4.2 Alternative 2: Monitoring with No Active Remediation . . . . . . . . 3-28

3.4.2.1 Effectiveness . . . . . . . . . . . . . . . . . . . 3-28

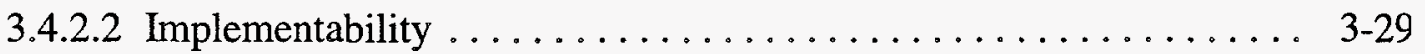

3.4 .2 .3 Cost $\ldots \ldots \ldots \ldots \ldots \ldots \ldots \ldots \ldots \ldots \ldots \ldots . \ldots \ldots$ 3-30

3.4.3 Alternative 3: Groundwater Removal with On-Site Treatment . . . . . . . . 3-30

3.4.3.1 Effectiveness ............................ 3-31

3.4.3.2 Implementability $\ldots \ldots \ldots \ldots \ldots \ldots \ldots \ldots \ldots \ldots \ldots . \ldots \ldots . \ldots \ldots \ldots$

3.4 .3 .3 Cost $\ldots \ldots \ldots \ldots \ldots \ldots \ldots \ldots \ldots \ldots \ldots \ldots \ldots . \ldots \ldots$ 


\section{CONTENTS (Cont.)}

3.4.4 Alternative 4: Containment .......................... 3-34

3.4.4.1 Effectiveness ............................. 3-34

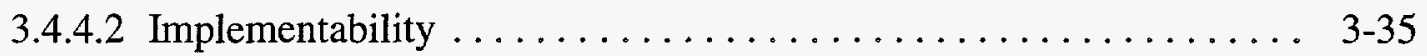

3.4.4.3 Cost .................................. 36

3.4.5 Alternative 5: In-Situ Treatment Using Permeable Barriers $\ldots \ldots \ldots \ldots .3-37$

3.4.5.1 Effectiveness ............................... 3-37

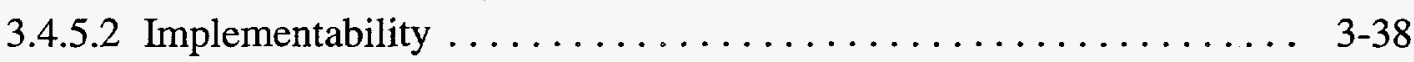

3.4.5.3 Cost ................................ 3-39

3.4.6 Alternative 6: Groundwater Removal at Selected Areas,

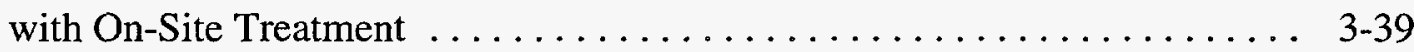

3.4.6.1 Effectiveness .............................. 3-40

3.4.6.2 Implementability $\ldots \ldots \ldots \ldots \ldots \ldots \ldots \ldots \ldots \ldots \ldots, 3-41$

3.4.6.3 Cost ................................ 3-43

3.5 Screening Summary and Identification of Final Alternatives $\ldots \ldots \ldots \ldots \ldots$ 3-44

4 DETAILED ANALYSIS OF FINAL ALTERNATIVES $\ldots \ldots \ldots \ldots \ldots \ldots \ldots \ldots$

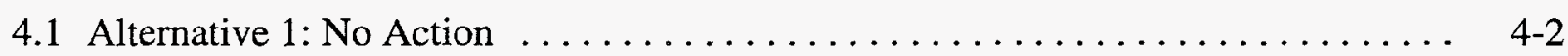

4.1.1 Overall Protection of Human Health and the Environment $\ldots \ldots \ldots \ldots .4-3$

4.1.2 Compliance with Potential ARARs ...................... 4-3

4.1.3 Long-Term Effectiveness and Permanence $\ldots \ldots \ldots \ldots \ldots \ldots \ldots \ldots . \ldots \ldots . \ldots \ldots$

4.1.3.1 Protection of Workers $\ldots \ldots \ldots \ldots \ldots \ldots \ldots \ldots \ldots \ldots \ldots, 4-4$

4.1.3.2 Protection of the Public $\ldots \ldots \ldots \ldots \ldots \ldots \ldots \ldots \ldots \ldots, 4-4$

4.1.3.3 Environmental Protection ..................... 4-4

4.1.4 Reduction of Toxicity, Mobility, and Volume through Treatment ....... 4-4

4.1.5 Short-Term Effectiveness . . . . . . . . . . . . . . . . . . . . .

4.1 .6 Implementability $\ldots \ldots \ldots \ldots \ldots \ldots \ldots \ldots \ldots \ldots \ldots \ldots \ldots, 4-5$

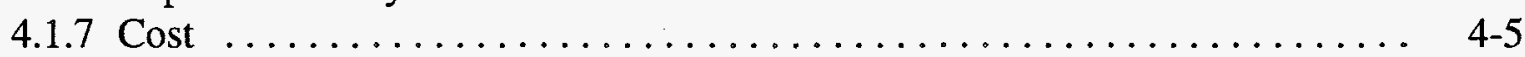

4.2 Alternative 2: Monitoring with No Active Remediation $\ldots \ldots \ldots \ldots \ldots \ldots$ 4 4 .

4.2.1 Overall Protection of Human Health and the Environment $\ldots \ldots \ldots \ldots .4-6$

4.2.2 Compliance with Potential ARARs ...................... 4-7

4.2.3 Long-Term Effectiveness and Permanence .................. 4-7

4.2.3.1 Protection of Workers $\ldots \ldots \ldots \ldots \ldots \ldots \ldots \ldots \ldots \ldots \ldots, 4-7$

4.2.3.2 Protection of the Public .......................... 4-7

4.2.3.3 Environmental Protection $\ldots \ldots \ldots \ldots \ldots \ldots \ldots \ldots \ldots . \ldots . \ldots . . .6$

4.2.4 Reduction of Toxicity, Mobility, or Volume through Treatment ........ . 4-8

4.2.5 Short-Term Effectiveness . . . . . . . . . . . . . . . . . . . . . . . . . 4

4.2.6 Implementability . . . . . . . . . . . . . . . . . . . . . . . . . . .

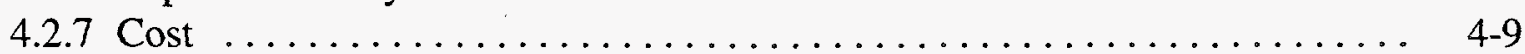

4.3 Alternative 6: Groundwater Removal at Selected Areas, with

On-Site Treatment .............................. 4-10

4.3.1 Overall Protection of Human Health and the Environment $\ldots \ldots \ldots . .44-16$ 


\section{CONTENTS (Cont.)}

4.3.2 Compliance with Potential ARARs $\ldots \ldots \ldots \ldots \ldots \ldots \ldots \ldots \ldots \ldots$. $4-16$

4.3.3 Long-Term Effectiveness and Permanence $\ldots \ldots \ldots \ldots \ldots \ldots \ldots \ldots .4 .18$

4.3.3.1 Protection of Workers ......................... 4-19

4.3.3.2 Protection of the Public ........................ 4-19

4.3.3.3 Environmental Protection .................... 4-20

4.3.4 Reduction of Toxicity, Mobility, and Volume through Treatment ....... 4-20

4.3.5 Short-Term Effectiveness . . . . . . . . . . . . . . . . . . . . . . . . 4-20

4.3.6 Implementability . . . . . . . . . . . . . . . . . . . . . . . . . .

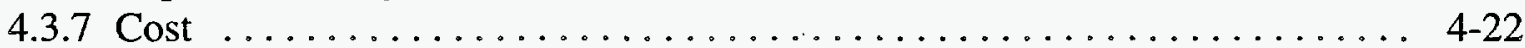

5 COMPARATIVE ANALYSIS OF ALTERNATIVES $\ldots \ldots \ldots \ldots \ldots \ldots \ldots \ldots$. 5 -1

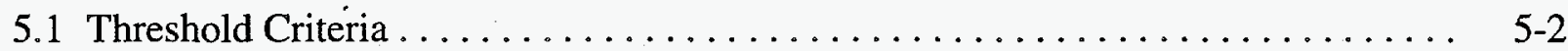

5.1.1 Overall Protection of Human Health and the Environment $\ldots \ldots \ldots \ldots .5-2$

5.1 .2 Compliance with ARARs $\ldots \ldots \ldots \ldots \ldots \ldots \ldots \ldots \ldots \ldots \ldots \ldots, 5-5$

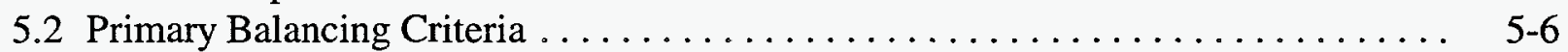

5.2.1 Long-Term Effectiveness and Permanence $\ldots \ldots \ldots \ldots \ldots \ldots \ldots \ldots$ 5-6

5.2.2 Reduction of Toxicity, Mobility, or Volume through Treatment ........ 5-6

5.2 .3 Short-Term Effectiveness . . . . . . . . . . . . . . . . . . . . . . . . . . 5 5-7

5.2 .4 Implementability .............................. 5-7

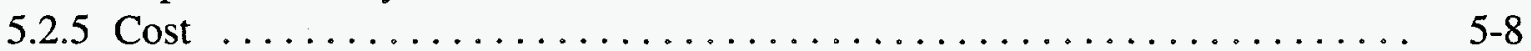

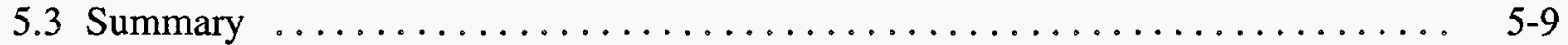

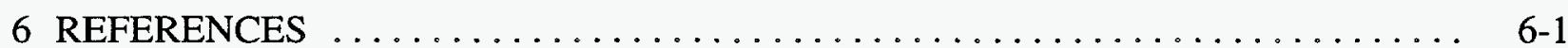

APPENDIX A: Regulatory Requirements Potentially Applicable or Relevant and Appropriate to the Remedial Action ................ A-1

APPENDIX B: Required Operational Period and Estimated Extraction Flow Rates of the Interceptor Trench $\ldots \ldots \ldots \ldots \ldots \ldots \ldots \ldots \ldots \ldots$ B-1

APPENDIX C: Bed Thickness and Operational Duration of the In-Situ Permeable Barrier for Alternative $5 \ldots \ldots \ldots \ldots \ldots \ldots \ldots$ C-1

APPENDIX D: Analytical Methodologies Used to Address Environmental Impacts for Alternatives in This Feasibility Study ........... D-1

APPENDIX E: Methodology and Assumptions Used to Determine the Costs of the Various Alternatives in This Feasibility Study ......... E-1

APPENDIX F: Distribution Coefficient Measurements in the Quarry Residuals Operable Unit Area ...................... 


\section{FIGURES}

$1.1 \quad$ Location of the Weldon Spring Site $\ldots \ldots \ldots \ldots \ldots \ldots \ldots \ldots \ldots \ldots \ldots \ldots \ldots \ldots \ldots$

1.2 Components of Weldon Spring Site Remediation $\ldots \ldots \ldots \ldots \ldots \ldots \ldots \ldots$

1.3 Area near the Weldon Spring Quarry $\ldots \ldots \ldots \ldots \ldots \ldots \ldots \ldots \ldots \ldots \ldots \ldots \ldots$

1.4 Regional Stratigraphy and Hydrostratigraphy of the Weldon Spring Area $\ldots \ldots \ldots$ 1-7

1.5 Cross Section through the Quarry Area $\ldots \ldots \ldots \ldots \ldots \ldots \ldots \ldots \ldots \ldots . . \ldots \ldots$

1.6 Typical Potentiometric Surface of the Shallow Aquifer $\ldots \ldots \ldots \ldots \ldots \ldots \ldots$

$1.7 \quad$ Soil Sampling Locations in the Quarry Proper $\ldots \ldots \ldots \ldots \ldots \ldots \ldots \ldots \ldots$

1.8 Surface Soil Sampling Locations Outside the Quarry Proper $\ldots \ldots \ldots \ldots \ldots \ldots$

1.9 Background and Subsurface Soil Sampling Locations

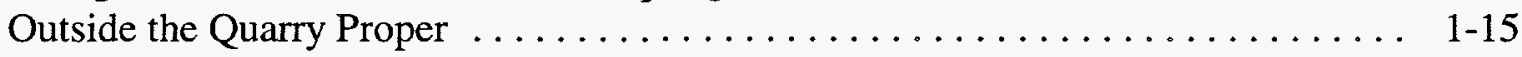

1.10 Locations of Background Wells, DOE Wells, and St. Charles County Wells .... 1-17

2.1 Potential Treatment Technologies for Groundwater Remediation of the QROU at the Weldon Spring Site $\ldots \ldots \ldots \ldots \ldots \ldots \ldots \ldots \ldots \ldots .2-2$

3.1 Location of the Proposed Groundwater Extraction System for Alternative $3 \ldots \ldots$ 3-7

3.2 Schematic of Typical Interceptor Trench System $\ldots \ldots \ldots \ldots \ldots \ldots \ldots \ldots$

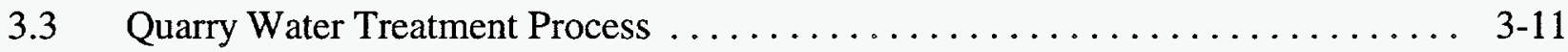

3.4 Schematic of Typical Keyed-In Slurry Wall System $\ldots \ldots \ldots \ldots \ldots \ldots \ldots \ldots$ 3-14

3.5 Schematic of Typical Keyed-In Permeable Barrier System ............... 3-19

3.6 Predicted Percentage of the Mass of Uranium Remaining in the Groundwater in the Area of the Contaminated Alluvium North of the Femme Osage Slough

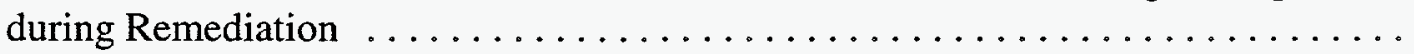

3.7 Location of the Proposed Groundwater Extraction System for Alternative 6 . . . . 3-22

3.8 Preconceptual Process Flow Diagram for Groundwater Treatment Using Portable Units 


\section{FIGURES (Cont.)}

B.1 Idealized Interceptor Trench Located Downgradient from an Idealized Contaminant Plume $\ldots \ldots \ldots \ldots \ldots \ldots \ldots \ldots \ldots \ldots \ldots \ldots \ldots \ldots$

B.2 Estimation of the Operational Duration of the Interceptor Trench

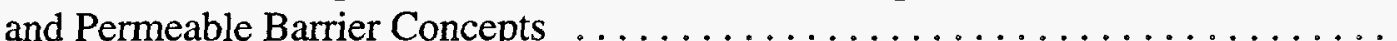

C.1 Idealized Representation of a Permeable Barrier for In-Situ Groundwater Treatment

C.2 Fraction of Adsorbate Remaining in a Fluid Stream after Adsorption by a Stationary Permeable Barrier

F.1 Sampling Locations for Distribution Coefficient Determination in the Weldon Spring Quarry Area .

\section{TABLES}

1.1 Final List of Human Health Contaminants of Potential Concern

for the QROU

1.2 Summary of Human Health Risk Estimates for the Quarry Area $\ldots . \ldots \ldots \ldots$. $1-21$

2.1 Summary of Screening Analysis for Institutional Controls and Monitoring

2.2 Summary of Screening Analysis for Natural Processes, In-Situ Containment, and In-Situ Treatment Measures

2.3 Summary of Screening Analysis for Groundwater Removal . . . . . . . . . . . . 2-15

2.4 Summary of Screening Analysis for Ex-Situ Treatment Measures $\ldots \ldots \ldots \ldots .2-20$

2.5 Screening of Potentially Applicable Technologies

for Groundwater Remediation

3.1 Estimated Uranium Concentrations in Groundwater Collected by the Interceptor Trench Design Proposed for Alternative 6

3.2 Screening of Preliminary Alternatives 


\section{TABLES (Cont.)}

4.1 Cost Estimate for Alternative $2 \ldots \ldots \ldots \ldots \ldots \ldots \ldots \ldots \ldots \ldots \ldots$

4.2 Cost Estimate for Alternative $6 \ldots \ldots \ldots \ldots \ldots \ldots \ldots \ldots \ldots \ldots \ldots \ldots$

5.1 Comparative Analysis of Alternatives $\ldots \ldots \ldots \ldots \ldots \ldots \ldots \ldots \ldots \ldots \ldots$

A.1 Quarry Residuals Operable Unit ARARs .................... A-12

D.1 Criteria Pollutant Emission Rate Factors $\ldots \ldots \ldots \ldots \ldots \ldots \ldots \ldots \ldots \ldots \ldots$

D.2 Predicted Emissions from Equipment Required for Monitoring
Well Construction $\ldots \ldots \ldots \ldots \ldots \ldots \ldots \ldots \ldots \ldots \ldots \ldots \ldots \ldots \ldots \ldots \ldots \ldots \ldots$

D.3 Predicted Emissions from Construction Worker Vehicles . . . . . . . . . . D-7

D.4 Total Predicted Construction Emissions for Alternative $2 \ldots \ldots \ldots \ldots \ldots$

D.5 Predicted Annual Emissions from Vehicles Used by Monitoring Workers ....... D-10

E.1 Weldon Spring-Specific Indirect Cost Relationships Applied

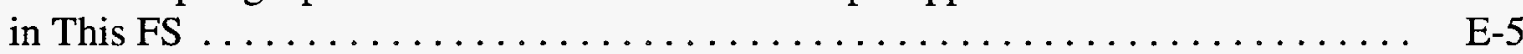

E.2 Characteristics of Proposed Additional Monitoring Wells for

E.3 Construction Cost Estimate for Alternative $2 \ldots \ldots \ldots \ldots \ldots \ldots \ldots$

E.4 Present-Worth Cost Calculation for Alternative $2 \ldots \ldots \ldots \ldots \ldots \ldots$ E-13

F.1 Water and Soil Sample Locations for $\mathrm{K}_{\mathrm{d}}$ Measurements $\ldots \ldots \ldots \ldots \ldots \ldots$

F.2 Measured Uranium-238 Concentrations for Water Samples and Suspended Solids . . . . . . . . . . . . . . . .

F.3 Measured Uranium-238 Concentrations for Water and Soil Samples in Equilibrium ........................... F-8

F.4 Measured Uranium-232 Concentrations for Water and Soil Samples in Equilibrium . . . . . . . . . . . . . . . . . . . . . . . F 


\section{NOTATION}

The following is a list of the acronyms, initialisms, and abbreviations (including units of measure) used in this document. Some acronyms used in tables or equations are defined only in the respective tables or equations.

\section{ACRONYMS, INITIALISMS, AND ABBREVIATIONS}

\section{General}

$\begin{array}{ll}\text { ACL } & \text { alternate concentration limit } \\ \text { AEC } & \text { Atomic Energy Commission } \\ \text { ALARA } & \text { as low as reasonably achievable } \\ \text { ARAR } & \text { applicable or relevant and appropriate requirement } \\ \text { BRA } & \text { baseline risk assessment } \\ \text { CERCLA } & \text { Comprehensive Environmental Response, Compensation, and Liability Act } \\ \text { CFR } & \text { Code of Federal Regulations } \\ \text { COC } & \text { contaminant of concern } \\ \text { COPC } & \text { contaminant of potential concern } \\ \text { D\&D } & \text { decontamination and decommissioning } \\ \text { DCG } & \text { Derived Concentration Guide } \\ \text { DOE } & \text { U.S. Department of Energy } \\ \text { DWEL } & \text { drinking water equivalent level } \\ \text { EPA } & \text { U.S. Environmental Protection Agency } \\ \text { FR } & \text { Federal Register } \\ \text { FS } & \text { feasibility study } \\ \text { GAC } & \text { granular activated carbon } \\ \text { HDPE } & \text { high density polyethylene } \\ \text { HGMS } & \text { high-gradient magnetic separation } \\ \text { K }_{d} & \text { distribution coefficient } \\ \text { MCL } & \text { maximum contaminant level } \\ \text { MCLG } & \text { maximum contaminant level goal } \\ \text { NCP } & \text { National Oil and Hazardous Substances Contingency Plan } \\ \text { NEPA } & \text { National Environmental Policy Act } \\ \text { NPDES } & \text { National Pollutant Discharge Elimination System } \\ \text { NPL } & \text { National Priorities List } \\ \text { NRC } & \text { U.S. Nuclear Regulatory Commission } \\ \text { O\&M } & \text { operation and maintenance } \\ \text { OSHA } & \text { Occupational Safety and Health Administration } \\ \text { OSWER } & \text { Office of Solid Waste Management } \\ \text { PAH } & \text { polycyclic aromatic hydrocarbon } \\ \text { PCB } & \text { polychlorinated biphenyl } \\ \text { PVC } & \text { polyvinyl chloride } \\ \text { QROU } & \text { quarry residuals operable unit }\end{array}$


QWTP quarry water treatment plant

RACES

Remedial Action Cost Estimating and Requirements System

RD/RA remedial design/remedial action

RfD reference dose

RI remedial investigation

ROD Record of Decision

SDWA Safe Drinking Water Act

TBC to-be-considered (requirement)

TSP total suspended particulates

UV ultraviolet

WSSRAP Weldon Spring Site Remedial Action Project

\section{Chemicals}

$\begin{array}{ll}\mathrm{CO} & \text { carbon monoxide } \\ \mathrm{DNT} & \text { dinitrotoluene } \\ \mathrm{HCl} & \text { hydrochloric acid } \\ \mathrm{NO} & \text { nitrogen oxides } \\ \mathrm{PAH} & \text { polycyclic aromatic hydrocarbon } \\ \mathrm{PCB} & \text { polychlorinated biphenyl } \\ \mathrm{SO}_{\mathrm{x}} & \text { sulfur oxides } \\ \mathrm{TNB} & \text { trinitrobenzene } \\ \mathrm{TNT} & \text { trinitrotoluene } \\ \mathrm{UO}_{2} & \text { uranium dioxide; uraninite (mineral form) } \\ \mathrm{USiO}_{4} & \text { coffinite }\end{array}$

\section{Units of Measure}

$\begin{array}{llll}{ }^{\circ} \mathrm{C} & \text { degree(s) Celsius } & \mathrm{h} & \text { hour(s) } \\ \mathrm{Ci} & \text { curie(s) } & \text { ha } & \text { hectare(s) } \\ \mathrm{cm} & \text { centimeter(s) } & \mathrm{in} . & \text { inch(es) } \\ \mathrm{cm}^{3} & \text { cubic centimeter(s) } & \mathrm{kg} & \text { kilogram(s) } \\ \mathrm{d} & \text { day(s) } & \mathrm{km} & \text { kilometer(s) } \\ \mathrm{dpm} & \text { disintegration(s) per minute } & \mathrm{L} & \text { liter(s) } \\ { }^{\circ} \mathrm{F} & \text { degree(s) Fahrenheit } & \mathrm{lb} & \text { pound(s) } \\ \mathrm{ft}^{\mathrm{d}} & \text { foot (feet) } & \mathrm{m} & \text { meter(s) } \\ \mathrm{ft}^{2} & \text { square foot (feet) } & \mathrm{m}^{2} & \text { square meter(s) } \\ \mathrm{ft}^{3} & \text { cubic foot (feet) } & \mathrm{m}^{3} & \text { cubic meter(s) } \\ \mathrm{g} & \text { gram(s) } & \mathrm{mg}^{2} & \text { milligram(s) } \\ \mathrm{gal} & \text { gallon(s) } & \mathrm{mi} & \text { mile(s) } \\ \mathrm{gpm} & \text { gallon(s) per minute } & \mathrm{min} & \text { minute(s) }\end{array}$




$\begin{array}{ll}\mathrm{mL} & \text { milliliter(s) } \\ \mathrm{mm} & \text { millimeter(s) } \\ \mathrm{mrem} & \text { millirem } \\ \mathrm{mSv} & \text { millisievert(s) } \\ \mathrm{pCi} & \text { picocurie(s) } \\ \mathrm{ppm} & \text { part(s) per million } \\ \mathrm{psi} & \text { pound(s) per square inch } \\ \mathrm{s} & \text { second(s) } \\ \mathrm{yd} & \text { cubic yard(s) } \\ \mathrm{yr} & \text { year(s) } \\ \mu \mathrm{g} & \text { microgram(s) } \\ \mu \mathrm{m} & \text { micrometer(s) }\end{array}$


ENGLISH/METRIC AND METRIC/ENGLISH EQUIVALENTS

\begin{tabular}{|c|c|c|}
\hline Multiply & By & To Obtain \\
\hline \multicolumn{3}{|l|}{ English/Metric Equivalents } \\
\hline acres & 0.4047 & hectares (ha) \\
\hline cubic feet $\left(\mathrm{ft}^{3}\right)$ & 0.02832 & cubic meters $\left(\mathrm{m}^{3}\right)$ \\
\hline cubic yards $\left(\mathrm{yd}^{3}\right)$ & 0.7646 & cubic meters $\left(\mathrm{m}^{3}\right)$ \\
\hline degrees Fahrenheit $\left({ }^{\circ} \mathrm{F}\right)-32$ & 0.5555 & degrees Celsius $\left({ }^{\circ} \mathrm{C}\right)$ \\
\hline feet $(\mathrm{ft})$ & 0.3048 & meters (m) \\
\hline gallons (gal) & 3.785 & liters $(\mathrm{L})$ \\
\hline gallons (gal) & 0.003785 & cubic meters $\left(\mathrm{m}^{3}\right)$ \\
\hline inches (in.) & 2.540 & centimeters $(\mathrm{cm})$ \\
\hline miles (mi) & 1.609 & kilometers $(\mathrm{km})$ \\
\hline pounds (lb) & 0.4536 & kilograms (kg) \\
\hline short tons (tons) & 907.2 & kilograms (kg) \\
\hline short tons (tons) & 0.9072 & metric tons $(\mathrm{t})$ \\
\hline square feet $\left(\mathrm{ft}^{2}\right)$ & 0.09290 & square meters $\left(\mathrm{m}^{2}\right)$ \\
\hline square yards (yd $\left.{ }^{2}\right)$ & 0.8361 & square meters $\left(\mathrm{m}^{2}\right)$ \\
\hline square miles $\left(\mathrm{mi}^{2}\right)$ & 2.590 & square kilometers $\left(\mathrm{km}^{2}\right)$ \\
\hline yards (yd) & 0.9144 & meters $(\mathrm{m})$ \\
\hline \multicolumn{3}{|l|}{ Metric/English Equivalents } \\
\hline centimeters $(\mathrm{cm})$ & 0.3937 & inches (in.) \\
\hline cubic meters $\left(\mathrm{m}^{3}\right)$ & 35.31 & cubic feet $\left(\mathrm{ft}^{3}\right)$ \\
\hline cubic meters $\left(\mathrm{m}^{3}\right)$ & 1.308 & cubic yards $\left(\mathrm{yd}^{3}\right)$ \\
\hline cubic meters $\left(\mathrm{m}^{3}\right)$ & 264.2 & gallons (gal) \\
\hline degrees Celsius $\left({ }^{\circ} \mathrm{C}\right)+17.78$ & 1.8 & degrees Fahrenheit $\left({ }^{\circ} \mathbf{F}\right)$ \\
\hline hectares (ha) & 2.471 & acres \\
\hline kilograms (kg) & 2.205 & pounds (lb) \\
\hline kilograms (kg) & 0.001102 & short tons (tons) \\
\hline kilometers $(\mathrm{km})$ & 0.6214 & miles (mi) \\
\hline liters $(L)$ & 0.2642 & gallons (gal) \\
\hline meters $(\mathrm{m})$ & 3.281 & feet $(\mathrm{ft})$ \\
\hline meters (m) & 1.094 & yards (yd) \\
\hline metric tons $(\mathrm{t})$ & 1.102 & short tons (tons) \\
\hline square kilometers $\left(\mathrm{km}^{2}\right)$ & 0.3861 & square miles $\left(\mathrm{mi}^{2}\right)$ \\
\hline square meters $\left(\mathrm{m}^{2}\right)$ & 10.76 & square feet $\left(\mathrm{ft}^{2}\right)$ \\
\hline square meters $\left(\mathrm{m}^{2}\right)$ & 1.196 & square yards $\left(\mathrm{yd}^{2}\right)$ \\
\hline
\end{tabular}




\section{FEASIBILITY STUDY FOR REMEDIAL ACTION \\ FOR THE QUARRY RESIDUALS OPERABLE UNIT AT THE WELDON SPRING SITE, WELDON SPRING, MISSOURI}

\section{INTRODUCTION}

The U.S. Department of Energy (DOE) is conducting cleanup activities at the Weldon Spring site, which is located in St. Charles County, Missouri, about $48 \mathrm{~km}$ (30 mi) west of St. Louis (Figure 1.1). Cleanup of the Weldon Spring site consists of several integrated components. The quarry residuals operable unit ( $Q R O U)$ is one of four operable units being evaluated. In accordance with the Comprehensive Environmental Response, Compensation, and Liability Act (CERCLA), as amended, a remedial investigation/feasibility study (RI/FS) is being conducted to evaluate conditions and potential responses for the following areas and/or media that constitute the QROU: (1) the residual material (soil and sediment) remaining at the Weldon Spring quarry after removal of the bulk waste (about 11 million L [ 3 million gal] of uranium-contaminated ponded water was also addressed previous to bulk waste removal); (2) other media located in the surrounding vicinity of the quarry, including adjacent soil, surface water, and sediment in Femme Osage Slough and several creeks; and (3) quarry groundwater located primarily north of Femme Osage Slough. Potential impacts to the St. Charles County well field downgradient of the quarry area are also being addressed as part of QROU RI/FS evaluations.

For remedial action sites, it is DOE policy to integrate values associated with the National Environmental Policy Act (NEPA) into the CERCLA decision-making process. The analyses contained herein address NEPA values as appropriate to the actions being considered for the QROU.

A work plan summarizing initial site conditions and providing conceptual site hydrogeological and exposure models was published in January 1994 (DOE 1994b). The RI (DOE 1998b) and baseline risk assessment (BRA) (DOE 1998a) reports have been completed. The RI discusses in detail the nature and extent and the fate and transport of contamination at the quarry area. The BRA provides a combined baseline assessment of potential human health and ecological impacts and estimates the magnitude of potential health risks and environmental impacts that would be associated with QROU contaminants if no remedial action were taken. This FS is being prepared to evaluate potential options for addressing contamination at the QROU in accordance with the integrated environmental compliance process for the Weldon Spring Site Remedial Acton Project (WSSRAP) (see Figure 1.2). This FS provides sufficient information to support an informed decision addressing the various components of the QROU. A brief description of the history and environmental setting of the quarry area is presented in Section 1.2. Key information regarding the nature and extent of contamination and the results of the BRA are presented in Sections 1.2 and 1.3, respectively. 


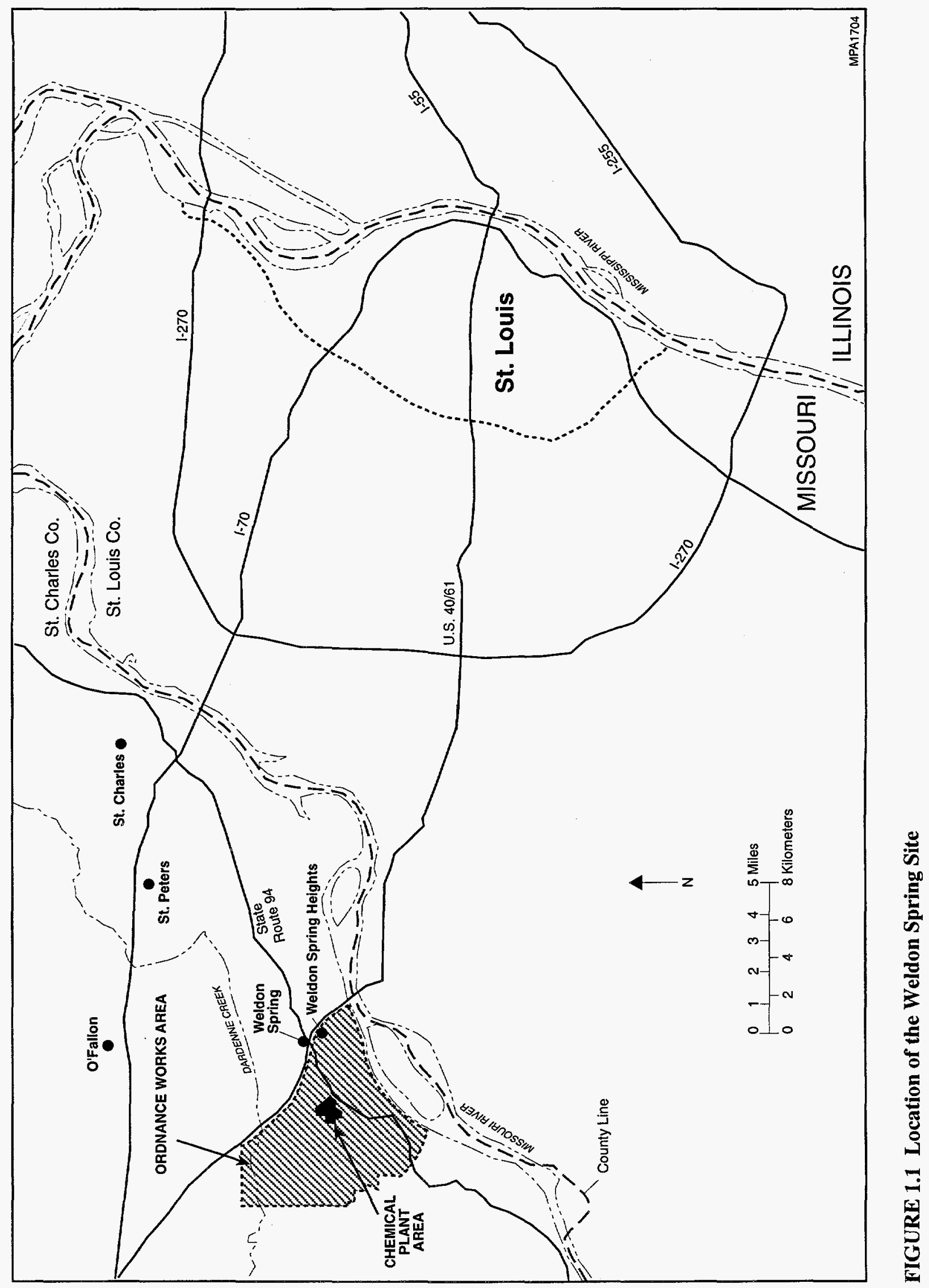




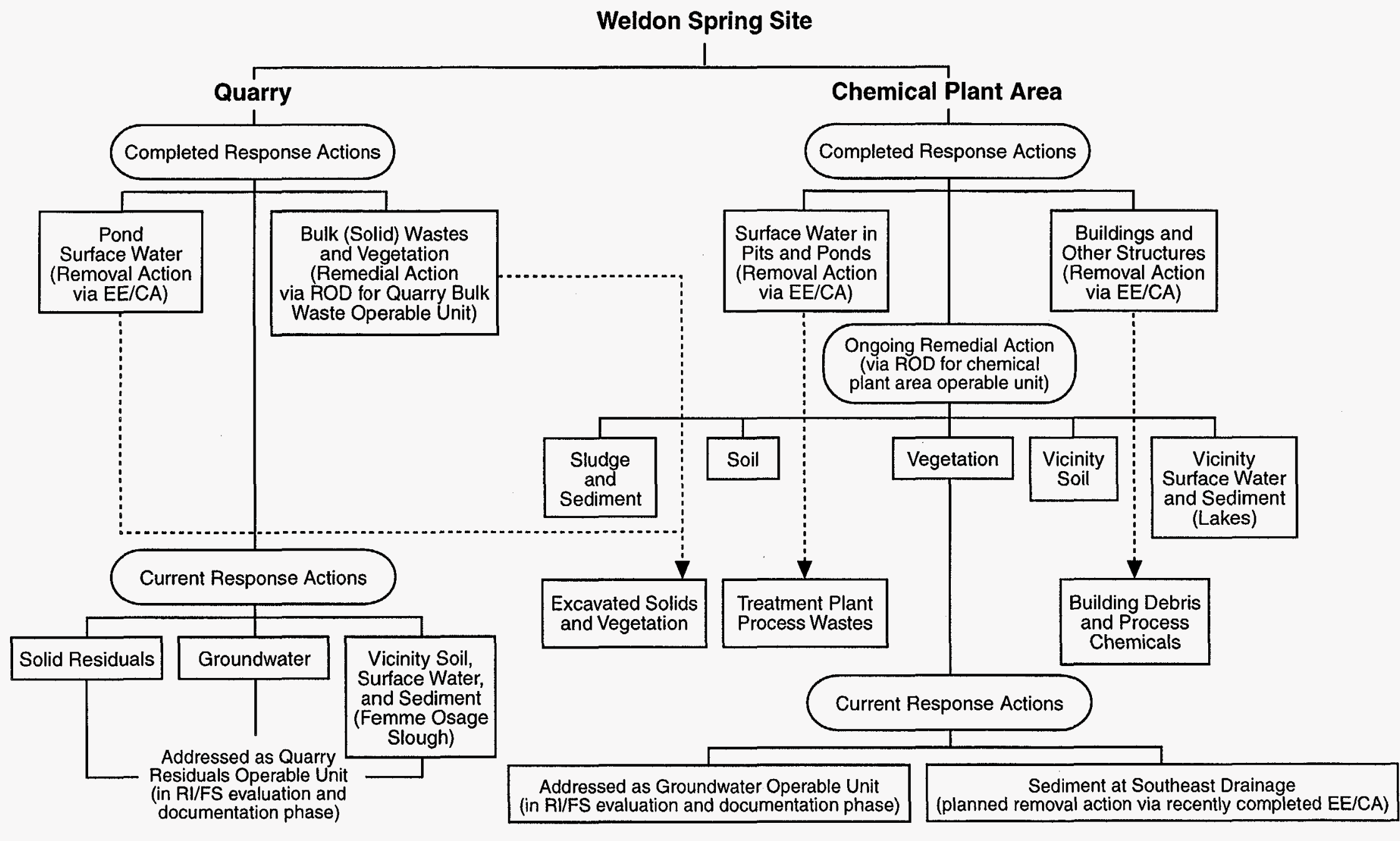

Note: The boxes represent contaminated media addressed by the project's cleanup actions for the chemical plant area and the quarry, and they are connected by solid lines to the appropriate phase of site cleanup. Dashed lines identify waste generated as a result of the completed response actions (e.g., plant treatment process wastes from treatment of quarry pond surface water) that is currently stored at the chemical plant area awaiting final placement in the disposal cell.

FIGURE 1.2 Components of Weldon Spring Site Remediation 


\subsection{SITE BACKGROUND}

\subsubsection{Site History and Description}

The Weldon Spring quarry is located in St. Charles County, Missouri, about $8 \mathrm{~km}(5 \mathrm{mi})$ southwest of the city of Weldon Spring and $48 \mathrm{~km}(30 \mathrm{mi})$ west of the city of St. Louis (Figure 1.3). The quarry is about $6.4 \mathrm{~km}$ ( $4 \mathrm{mi}$ ) south-southwest of the chemical plant area; it is accessible from State Route 94 and is currently fenced and closed to the public. The quarry is surrounded by the Weldon Spring Conservation Area (Figure 1.3). In October 1985, the U.S. Environmental Protection Agency (EPA) proposed to list the Weldon Spring quarry on the National Priorities List (NPL) because of its proximity to the St. Charles County well field; this listing occurred in July 1987 (EPA 1987).

The quarry was excavated into a limestone bluff that forms a valley wall at the edge of the Missouri River alluvial floodplain. Before 1942, the quarry was mined for limestone to support various construction activities. The quarry is about $300 \mathrm{~m}(1,000 \mathrm{ft})$ long by $140 \mathrm{~m}(450 \mathrm{ft})$ wide and covers an area of approximately 3.6 ha ( 9 acres).

The quarry was used by the Army for disposal of chemically contaminated (explosive) materials beginning in the 1940s and was transferred to the U.S. Atomic Energy Commission (AEC) in July 1960 for use as a disposal site for radioactively contaminated materials. The AEC used the quarry to dispose of uranium and thorium residues (drummed and uncontained), radioactively contaminated building rubble and process equipment, and trinitrotoluene (TNT) and dinitrotoluene (DNT) residues from cleanup of the former ordnance works.

In October 1995, the removal of approximately $107,037 \mathrm{~m}^{3}\left(140,000 \mathrm{yd}^{3}\right)$ of soil and waste material from the quarry was completed. This material was transported to the chemical plant area for final placement in the disposal cell, which will soon be completed.

Prior to bulk waste removal, an estimated $11,000 \mathrm{~m}^{3}$ ( 3 million gal) of contaminated water contained in the quarry pond was also removed and treated. Although technically a surface water body, the quarry pond is isolated from the surface water system. The quarry pond collects rainwater and surface water runoff from the rim and higher levels of the quarry proper. The pond also receives some groundwater discharge along its northern, upgradient wall and discharges to the groundwater via near horizontal partings near the Kimmswick Limestone/Decorah Formation contact along its southern wall.

Currently, routine monitoring is performed for uranium. Since April 1996, uranium levels have fluctuated between 400 and $550 \mathrm{pCi} / \mathrm{L}$ but have never exceeded the $600 \mathrm{pCi} / \mathrm{L}$ criterion (DOE 1998a). In addition, restoration of the quarry proper itself is currently being planned. Plans would 


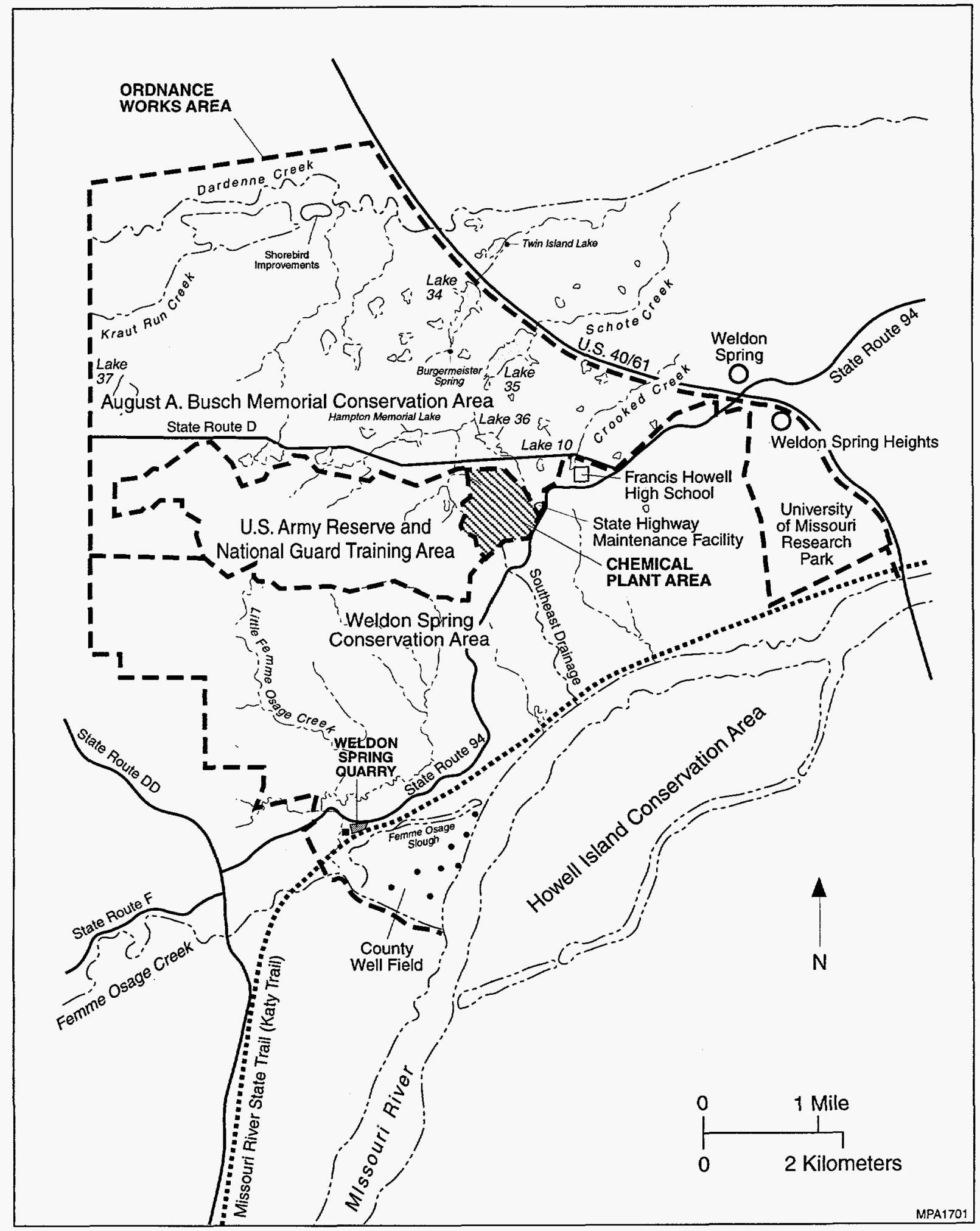

FIGURE 1.3 Area near the Weldon Spring Quarry 
include removal of potentially remaining contaminated soils and structures, backfilling the quarry, final grading, and haul road restoration. One of the first tasks of restoration is the removal of existing structures (e.g., the quarry water treatment plant (QWTP) and associated structures) and contaminated soils remaining in the quarry proper, primarily soils in the North Slope area. Preliminary characterization of the North Slope area has becn performed; results indicate potentially contaminated soil to be present. A complete determination has not been possible because of access limitations. The area in question is fairly steep. Consequently, the potential for exposure to contaminated soil, if any, is not likely. Some minor residual contamination present within the drainage ditch near the transfer station and possible soils underneath the transfer station would also be removed.

The current restoration design plan includes backfilling the quarry with soil to reduce fall hazards and to stabilize the north and south highwalls. The backfill would cover and fill all floor fractures at the $152-\mathrm{m}(500-\mathrm{ft})$ bench and below with at least $2 \mathrm{~m}(5 \mathrm{ft})$ of material. The material used for backfill will be engineered to reduce the potential for mobilization of residual contaminants into the groundwater. Restoration will be designed to either force groundwater flow to go around the inner quarry area, or alternatively, cause the groundwater within the footprint of the inner quarry area to pass through an attenuation layer to prevent the flow of contamination. More definitive specifications regarding backfill activities will be determined in the design phase of quarry restoration. The design will also effectively prevent residual contaminants in the cracks and fissures (i.e., flakes of yellowcake) from mobilizing to the surface through erosion and/or freeze/thaw action, thus further reducing the low potential risks associated with external gamma radiation and ingestion. Mobilization of contaminants into the groundwater will not be likely, because the benches are in the unsaturated portions of the bedrock, and infiltration of precipitation will be prevented by the final grading designed to promote sheetflow. Restoration will be designed to prevent ponding of water in the quarry and to minimize erosion. Final grading of the quarry will be accomplished to leave the area compatible with sheetflow and to return the area as close as possible to its natural contours. Haul road restoration is expected to be minimal. Restoration activities are currently planned for the fall of 1999.

\subsubsection{Site Environmental Setting}

\subsubsection{Soil and Geology}

The generalized hydrostratigraphy in the Weldon Spring area is presented in Figure 1.4. Regional aquifers include shallow, middle, and deep bedrock systems and the alluvial system (Kleeschulte and Emmett 1986). Upper and lower confining units are also defined in the regional. hydrostratigraphy. The shallow bedrock aquifer system and the upper confining unit shown in Figure 1.4 are not present near the quarry. 


\begin{tabular}{|c|c|c|c|c|c|c|}
\hline SYSTEM & SERIES & $\begin{array}{l}\text { STRATIGRAPHIC } \\
\text { UNIT }\end{array}$ & $\begin{array}{l}\text { TYPICAL } \\
\text { THICKNESS } \\
\text { (FT. I(1) }\end{array}$ & LITHOLOGY & PHYSICAL CHARACTERISTICS & HYOROSTRATIGRAHIC UNIT \\
\hline \multirow{2}{*}{ OUATERNARY } & HOLOCENE & ALLUVIUM & $0-120$ & 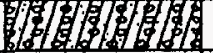 & GRAVELLY. SILTY LOAM. & ALLUUVIAL AOUIFER \\
\hline & PLE ISTOCENE & $\begin{array}{l}\text { LOESS AND } \\
\text { GLACIAL DRIFT (2) }\end{array}$ & $10-60$ & & $\begin{array}{l}\text { SILTY CLAY. GRAVELLY CLAY, SILTY LOAM. OR } \\
\text { LOAM OVER RESIOUUM FROM WEATHEREO BEOROCK. }\end{array}$ & \multirow{3}{*}{ (UNSATURATED) (2) } \\
\hline \multirow{5}{*}{ MISSISSIPPIAN } & \multirow[b]{2}{*}{ MERAMECIIAN } & SALEM FOAMATION (3) & $0-15$ & & $\begin{array}{l}\text { LINESTONE. LILEY DOLOWITE. FINELY TO COARSELY } \\
\text { CRYSTALINE. MASSIVELY BEDDED. AND THIN BEDOED SHALE. }\end{array}$ & \\
\hline & & WARSAW FORMATION (3) & $60-80$ & & $\begin{array}{l}\text { SHALE AND THIN TO MEDIUM BEDDED FINELLY } \\
\text { CAYSTALINE LINESTONE WITH INTERBEDDED CHERT. }\end{array}$ & \\
\hline & \multirow{2}{*}{ OSAGEAN } & $\begin{array}{l}\text { BURLINGTON AND } \\
\text { KEDKUK LIMESTONES }\end{array}$ & $100-200$ & & $\begin{array}{l}\text { CHHETY LIMESTONE, VERY FINE TO VERY COARSELY } \\
\text { CRYSTAL INE. FOSSILIFEROUS. THICKLY BEDDED TO MASSIVE. }\end{array}$ & \multirow{2}{*}{ SHALLOW AOUIFER SYSTEM } \\
\hline & & $\begin{array}{l}\text { FERN GLEN } \\
\text { LIMESTONE. }\end{array}$ & $45-70$ & & $\begin{array}{l}\text { CHERTY LINESTONE. OOLOMITIC IN PART. VERY FINE YO } \\
\text { VERY COARSELY CRYSTAL INE. WEODIUM TO THICKLY BEDOED. }\end{array}$ & \\
\hline & X INDERHDOK I AN & CHOUTEAU LIMESTONE & $20-50$ & & $\begin{array}{l}\text { DOLOMITIC. ARGILLACEOUS LIWESTONE: FINELY } \\
\text { CRYSTAL INE, THIN TO NEDIUM BEODED. } \\
\end{array}$ & \multirow{4}{*}{$\begin{array}{l}\text { UPPER LEAKY } \\
\text { CONF INING UNIT }\end{array}$} \\
\hline \multirow[b]{2}{*}{ DEVONIAN } & \multirow[b]{2}{*}{ UPPER } & $\begin{array}{l}\text { SULPHUR SPRINGS GROUP, } \\
\text { BUSHEERG SANOSTONE }\end{array}$ & & & OUARTZ ARERNITE. FINE TO MEDIUM GRAINED, FRIABLE. & \\
\hline & & $\begin{array}{l}\text { LOWER PART OF SULPHUR } \\
\text { SPRINGS GROUP UNOIFFESTIIITEO }\end{array}$ & $40-55$ & & $\begin{array}{l}\text { CALCAREOUS SILTSTONE, SANDSTONE, COLITIC } \\
\text { LIMESTONE, AND HARD CARBONACEDUS SHALE. }\end{array}$ & \\
\hline \multirow{11}{*}{ ORDOVICIAN } & CINCINNATIAN & MAOUOKETA SHALE (5) & $10-30$ & & $\begin{array}{l}\text { CALCAREOUS TO DOLOMITIC SILTY SHALE ANO } \\
\text { WUDSTONE. THINLY LAMINATEO TO MASSIVE. }\end{array}$ & \\
\hline & \multirow{5}{*}{ CHAMPLAINIAN } & KIMNSWICK LINESTONE & $70-100$ & & $\begin{array}{l}\text { LIMESTONE, COAFSELY CAYSTALLTINE, REOTUM TO THICKLY } \\
\text { BEODEO. FOSSILIFEROUS ANO CHERTY NEAR BASE. }\end{array}$ & MIDDLE AOUIFER SYSTEM \\
\hline & & DECORAH GROUP & $30-60$ & & $\begin{array}{l}\text { SHALE WITH THIN INTERBEDS OF VERY } \\
\text { FINELY CRYSTAL INE LINESTONE. }\end{array}$ & \multirow{3}{*}{$\begin{array}{l}\text { LOWER CONF INING } \\
\text { UNIT }\end{array}$} \\
\hline & & PLATTIN LIMESTONE & $100-130$ & & $\begin{array}{l}\text { DOLOWIIIC LILESTONE. VERY FINELLY CRYSTALL INE. } \\
\text { FOSSILIFEROUS. THINLY BEDED. }\end{array}$ & \\
\hline & & JOACHIM DOLOMITE & $80-105$ & & 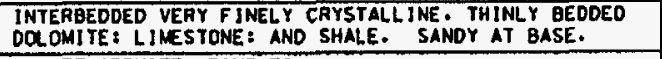 & \\
\hline & & ST. PETER SANDSTONE & $120-150$ & monsting & $\begin{array}{l}\text { OUARTZ ARENITE. FINE TO } \\
\text { MEDIUM GRAINED. MASSIVE. }\end{array}$ & \multirow{8}{*}{ DEEP AOUIFER SYSTEM } \\
\hline & \multirow{5}{*}{ CANADIAN } & POWELL DOLOMITE & $50-60$ & $2=2-2$ & $\begin{array}{l}\text { SANDY DOLOMITE, MEDIUM TO FINELY } \\
\text { CAYSTALINE. MINOR CHERT AND SHALE. }\end{array}$ & \\
\hline & & COTTER DOLAMITE & $200-250$ & & $\begin{array}{l}\text { ARGILLACEOUS. CHERTY DOLOMITES FINE TO NEDIUM } \\
\text { CRYSTALLINE. INTERBEDDED WITH SHALE. }\end{array}$ & \\
\hline & & JEFFERSON CITY DOLOMITE & $160-180$ & 23 & DOLOMITE. FINE TO MEDIUM CRYSTALINE. & \\
\hline & & ROUEIDOUX FORMATION & $150-170$ & $\quad 2$ & DOLOMITIC SANDSTONE. & \\
\hline & & GASCONADE DOLOMITE & 250 & 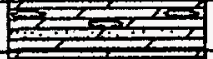 & $\begin{array}{l}\text { CHERTY DOLOMITE ANO ARENACEOUS } \\
\text { DOLOMITE IGUNTER MEMEER I. }\end{array}$ & \\
\hline \multirow[b]{2}{*}{ CAMBRIAN } & \multirow[b]{2}{*}{ UPPER } & EMINENCE DOLOMITE & 200 & $2 x^{2}$ & $\begin{array}{l}\text { DOLOMITE, MEDIUM TO COARSELY CRYSTALL INE, } \\
\text { MEDIUM BEODED TO MASSIVE. }\end{array}$ & \\
\hline & & POTOSI DOLOMITE & 100 & 2 & $\begin{array}{l}\text { DOLOMI TE. FINE TO MEOIUM CAYSTALLINE. THICKLY } \\
\text { BEDOED TO MASSIVE. DRUSY OUARTZ COMMON. }\end{array}$ & \\
\hline
\end{tabular}

(1) THICKNESS DATA SOURCES VAPY OUATERNARY UNIT THICKNESS BASED ON ON-SITE ORILLING AND TRENCHING. BURL 1NGTON AND KENOSTONE AND BELOW FROM KLEESCHULTE AND EMMETT (REF 54 ).

(4) THE SULPHUR SPRINGS GROUP ALSO INCLUDES THE BACHELOR SANOSTONE AND THE GLEN PARK LIMESTO
LAND SURVE. (REF 531

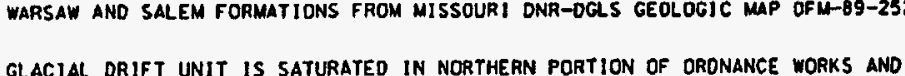

(5) THE MAQUOKETA SHALE IS NOT PRESENT IN the WELDON SPRING AREA BASED ON

21 GLACIAL ORIFT UNIT IS SATURATEO IN NORTHERN PORTION OF ORONAN
GEHAVES LOCALLY AS A LEAKY CONF INING UNIT. IGEOLOGIC LOG

(3) THE WARSAW AND SALEN FORMATIONS ARE CONSIDERED TO BE ABSENT FROM THE WELDON SPRING

FIGURE 1.4 Regional Stratigraphy and Hydrostratigraphy of the Weldon Spring Area 
Unconsolidated surficial materials are present in the area of the Weldon Spring quarry; loess deposits and residual soils cover the upland regions, and alluvium occurs along the stream and river valleys. Coarse-grained deposits constitute the bottom 6 to $24 \mathrm{~m} \mathrm{(20} \mathrm{to} 80 \mathrm{ft}$ ) of the Missouri River floodplain. Fine-grained deposits constitute the upper 4.6 to $7.6 \mathrm{~m}$ (15 to $25 \mathrm{ft}$ ) of the Missouri River floodplain and the full thickness of Little Femme Osage Creek and the Femme Osage Creek alluvium (DOE 1998b).

The uppermost bedrock unit in the vicinity of the quarry is the Kimmswick Limestone of Ordovician age. The Kimmswick Limestone is underlain by other Ordovician strata that include, in descending order, the Decorah Group (shale and limestone), Plattin Limestone, Joachim Dolomite, and St. Peter Sandstone. The sides of the quarry expose the Kimmswick Limestone, whereas the bedrock floor of the quarry lies in the upper portion of the Decorah Group. The original floor of the quarry was excavated about $5 \mathrm{~m}$ (15 ft) into the Decorah Group (DOE 1998b).

The Kimmswick Limestone is characterized by solution-enlarged features associated with the intersection of vertical joints, bedding planes, and fractures. The Decorah Group lies below the Kimmswick Limestone and is composed of finely crystalline to lithographic limestone. It is about

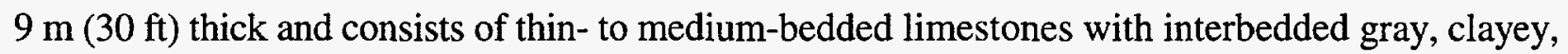
fossiliferous shale (Whitfield et al. 1989). Underlying the Kimmswick Limestone and the Decorah Group is the Plattin Limestone, a slightly cherty limestone that is finely crystalline to lithographic and thin to medium bedded. The lower 1.5 to $3 \mathrm{~m}$ ( 5 to $10 \mathrm{ft}$ ) is sometimes a dolomitic limestone that is argillaceous and fine to medium crystalline. It ranges in thickness from about 24 to $41 \mathrm{~m}$ (80 to $135 \mathrm{ft}$ ) and contains enlarged solution joints in many places (Whitfield et al. 1989). The Joachim Dolomite, which ranges from 18 to $24 \mathrm{~m}$ (60 to $80 \mathrm{ft}$ ) in thickness, underlies the Plattin Limestone. East and south of the quarry, the Kimmswick Limestone and Decorah Group are truncated by an erosional surface that is overlain by alluvial deposits associated with the Femme Osage Slough and the Missouri River (Figure 1.5).

The alluvium extends from the base of the bedrock bluffs along Katy Trail to the Missouri River. The primary sediments between the bedrock bluffs and Femme Osage Slough are silts and clays. Between the quarry and Little Femme Osage Creek are silts and clays, with several layers of sand down to bedrock. The alluvial material south of the slough consists of about $5 \mathrm{~m}(15 \mathrm{ft})$ of silty clay material underlain by well-graded sands and gravels to bedrock. The contact between the Kimmswick Limestone and Decorah Group, which may provide the primary pathways for migration of contaminants from the quarry area, is in contact with fine-grained soils, silty clay, and organic silt and clay north of Femme Osage Slough (DOE 1998b). Clay fillings are present in many of the joints. The fracture surfaces along the bluff and on the quarry walls are typically etched with patterns, an indication that most of the fractures have been in contact with groundwater. Field observations and borehole infiltration tests suggest that, with depth, the joints become increasingly tight and that the number and size of fractures decrease (DOE 1998b). 


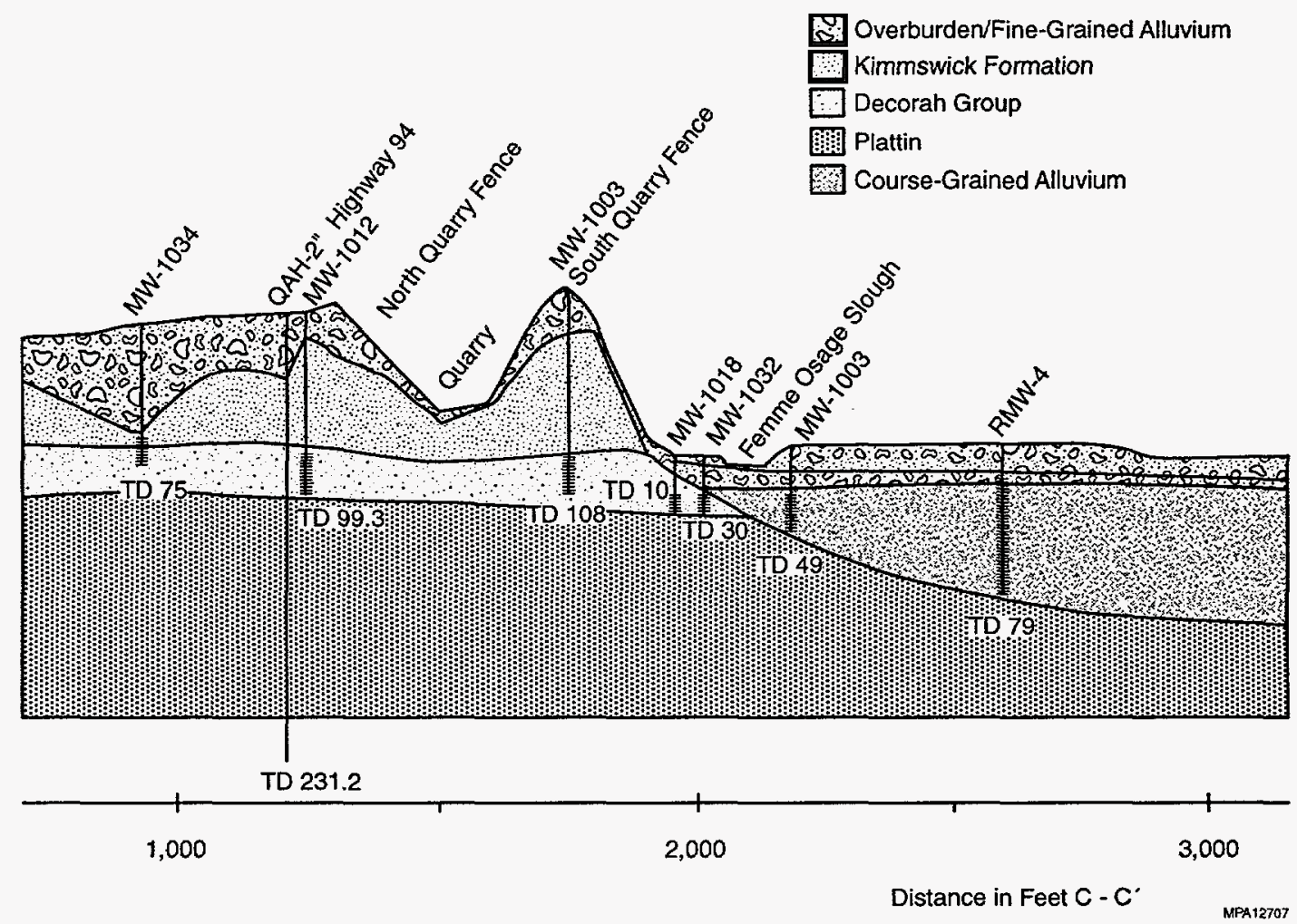

FIGURE 1.5 Cross Section through the Quarry Area

\subsubsection{Hydrogeology}

Groundwater in the vicinity of the quarry occurs in alluvium, fractured limestone, and sandstone (Berkeley Geosciences Associates 1984). The uppermost groundwater unit is composed of carbonate rocks near the quarry, tributary alluvium near Little Femme Osage Creek, and Missouri River alluvium between the quarry bluff and the Missouri River. Water table (unconfined) conditions typically occur in the alluvium; confined to semiconfined conditions occur in the bedrock and alluvium where layers of varying permeability are present. The St. Peter Sandstone, about $90 \mathrm{~m}$ $(300 \mathrm{ft})$ below the floor of the quarry, constitutes the deeper aquifer.

In the vicinity of the quarry, groundwater flows primarily from north to south, and a westward gradient runs from the quarry to Little Femme Osage Creek. South of the quarry rim, the direction of the groundwater flow is generally south to southeast toward Femme Osage Slough. In

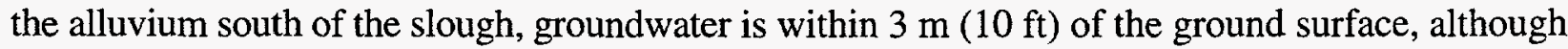
the depth to water varies with seasonal pumping demands in the nearby St. Charles County well field and with water levels in the Missouri River (see Figure 1.6). 


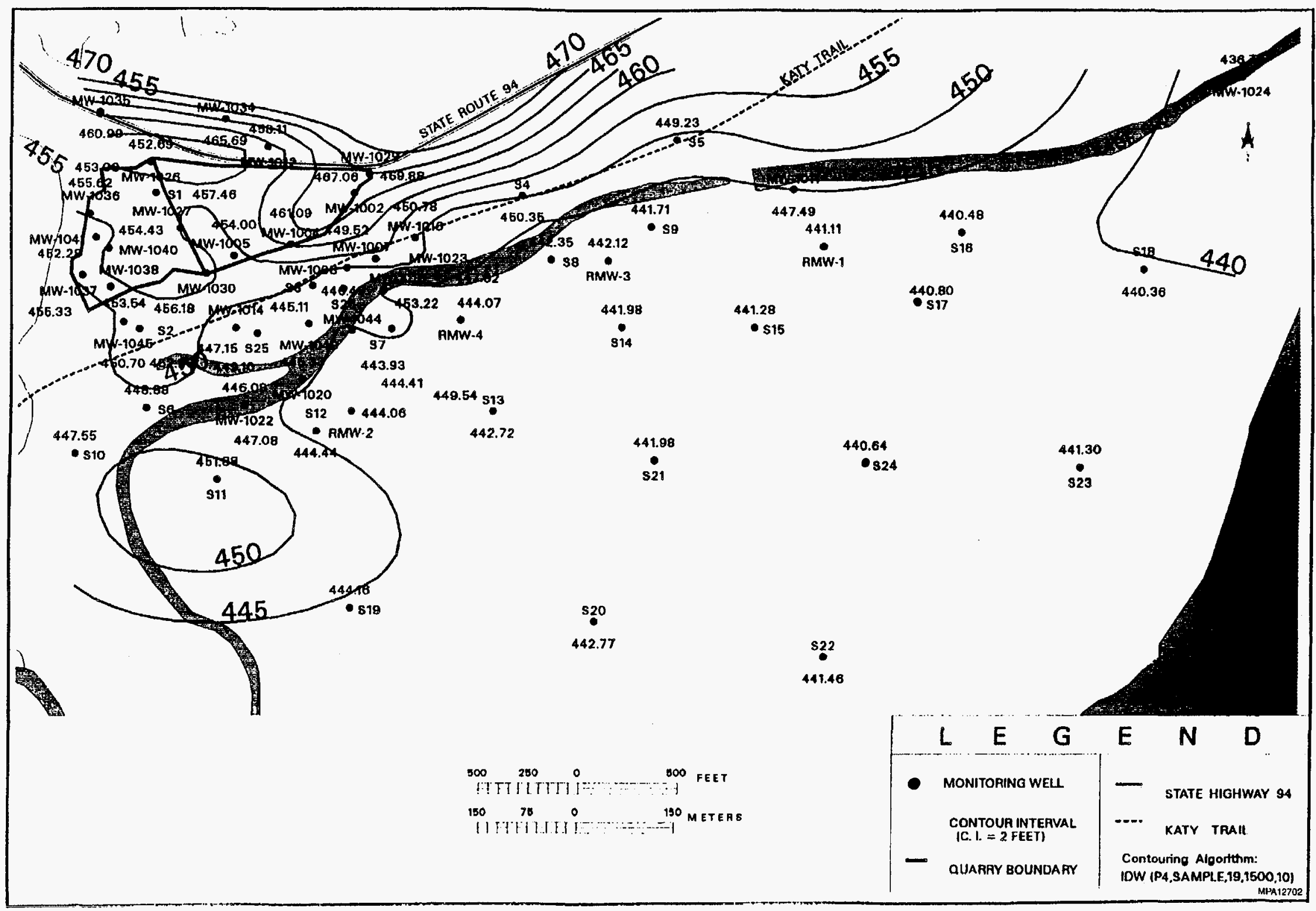

FIGURE 1.6 Typical Potentiometric Surface of the Shallow Aquifer 
Between Katy Trail and the slough, shallow groundwater flow occurs in fine sediments that have low hydraulic conductivities. Well yields in this area typically range from less than 0.03 to $0.16 \mathrm{~L} / \mathrm{s}(0.5$ to $2.5 \mathrm{gpm})$. With increasing distance from the slough, the sediments become more coarse and the hydraulic conductivity increases. The St. Charles County wells pump an average of 10.5 million gallons per day based on the typical five-well production scheme.

The hydraulic gradient between Katy Trail and the slough is generally southward toward the slough. In general, the groundwater elevation data indicate a southeasterly gradient across the slough. At most locations, the slough is a source of recharge to the shallow groundwater. However, at some locations north of the slough, groundwater levels are higher, indicating discharge to the slough (DOE 1998b).

Recharge to the bedrock in the vicinity of the quarry is limited to infiltration from precipitation or storm runoff. The bedrock discharges to the Missouri River alluvium. Recharge to the alluvium south of the slough occurs primarily from the Missouri River, intermittent surface flooding, infiltration of precipitation, and discharge from the bedrock.

\subsubsection{Biotic Resources}

Much of the land surrounding the quarry consists of three state-owned conservation areas: August A. Busch Memorial Conservation Area, Weldon Spring Conservation Area, and Howell Island Conservation Area. These conservation areas contain second-growth forest; the nonforested areas are actively managed for upland game production.

Aquatic habitats in the vicinity of the quarry include the Missouri River, Little Femme Osage Creek, Femme Osage Slough, and numerous small, unnamed creeks, drainages, and ponds throughout the Weldon Spring Conservation Area. In addition, the nearby August A. Busch Memorial Conservation Area contains more than 35 ponds and lakes; however, these ponds and lakes are in the Mississippi River drainage and are not influenced by the quarry area.

The U.S. Fish and Wildlife Service (Frazer 1995) has identified the potential for five federal-listed threatened or endangered species to occur in the vicinity of the quarry area: three birds (bald eagle, peregrine falcon, interior least tern), one fish (pallid sturgeon), and one plant (decurrent false aster). The Fish and Wildlife Service has also identified several candidate species as possibly occurring in the area. The Missouri Department of Conservation has identified 13 state endangered and 19 state rare species for St. Charles County (Dickneite 1995). However, many of these species are not expected to occur at the quarry area; some only pass through the area during migration. For other species, the quarry does not contain suitable habitat. To date, only the bald eagle has been observed in the vicinity of the quarry area (DOE 1998b), and all of those birds were sighted near the Missouri River and away from the quarry proper. 


\subsubsection{Land Use and Demography}

The Weldon Spring quarry is located within the Weldon Spring Conservation Area, which occupies an area of 2,977 ha (7,356 acres) and is managed for recreational use by the Missouri Department of Conservation. The August A. Busch Memorial Conservation Area and the Howell Island Conservation Area are north and east of the quarry, respectively. The Busch and Weldon Spring conservation areas collectively receive over 1 million visitors each year (Crigler 1992). Katy Trail traverses the Weldon Spring Conservation Area along the route of an abandoned railroad bed that runs adjacent to the southern margin of the quarry. This trail, which was established by the Missouri Department of Natural Resources, is used annually by several thousand people from the local area.

Local communities include Defiance, which is situated about $5 \mathrm{~km}(3 \mathrm{mi})$ from the quarry with a population of 100, and Weldon Spring and Weldon Spring Heights, which are located about $8 \mathrm{~km}(5 \mathrm{mi})$ northeast of the quarry and support a combined population of approximately 1,500 (U.S. Bureau of the Census 1991).

\subsection{NATURE AND EXTENT OF CONTAMINATION}

The nature and extent of contamination at the QROU are discussed in detail in the RI (DOE 1998b). The following brief summary is included to provide the necessary background information to indicate the relevance of the technologies and alternatives that have been evaluated for this FS.

Contaminated media at the QROU can be generally categorized into three separate entities: (1) residual soil inside the quarry proper and alluvial soil outside the quarry proper, (2) contaminated surface water and sediment at Femme Osage Slough and nearby creeks (Little Femme Osage Creek and Femme Osage Creek), and (3) contaminated groundwater in the shallow aquifer system (primarily north of the slough). Background samples were also collected for each medium of concern to delineate those naturally occurring contaminants attributable to the site.

\subsubsection{Soil}

At the quarry proper, soil was sampled from the rims and slopes, and sediments were sampled from wall and floor fractures and from the ramp and floor of the quarry sump (see Figure 1.7). Potential contaminants identified in soil samples from the rims and slopes included isotopes of radium, thorium, and uranium; select metals; nitroaromatic compounds; polycyclic aromatic hydrocarbons (PAHs); and polychlorinated biphenyls (PCBs). In disturbed soil on the rim and knoll of the quarry, only selenium, silver, zinc, radium-226, thorium-230, and uranium-238 were detected at concentrations significantly higher than background levels. In samples from the quarry 


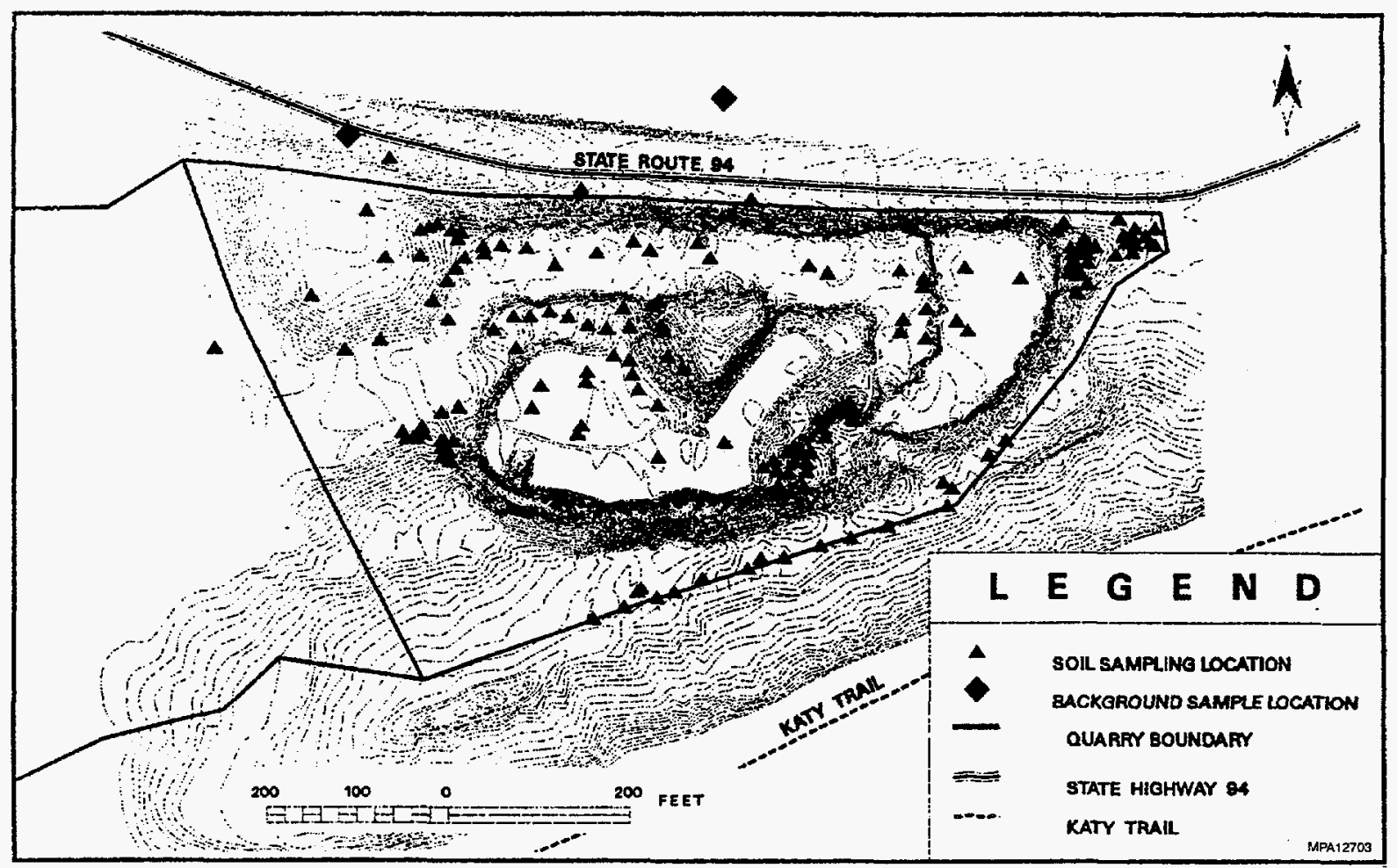

\section{FIGURE 1.7 Soil Sampling Locations in the Quarry Proper}

fractures, lower levels of contamination were found in the wall fractures than in floor fractures. Radium, thorium, and uranium isotopes and aluminum, selenium, and silver were detected at concentrations exceeding background levels; samples collected from the sump area were primarily contaminated with radium-226, thorium-230, uranium, and low levels of PAHs. A radiological survey of the quarry rock surfaces was also performed. Exposure rate measurements elevated above background levels were primarily limited to fractures or depressions where sediment and fine particles of waste have accumulated.

Outside the quarry proper, surface and subsurface soil samples were collected; the focus was on the area south of the quarry between the Katy Trail and Femme Osage Slough (see Figures 1.8 and 1.9). The area sampled included Vicinity Property 9, which was remediated in 1996 under the Record of Decision (ROD) for the chemical plant area (DOE 1993b). Low concentrations (but higher than background levels) of uranium are sorbed onto soils located between the quarry and the slough. Lead and zinc were detected at low levels above background in shallow soils south and east of the quarry. Elevated levels of metals in this area may have been transported in groundwater from the quarry, but may also have been derived from flood-related overbank deposits of fine sediment carried by the Missouri River or from runoff from the Ordnance Works area. Low levels of nitroaromatic compounds (i.e., less than $1.7 \mathrm{ppm}$ ) were detected in soils to the east, west, and south of the quarry. Contamination was generally found in shallow soil, but was also detected in a 


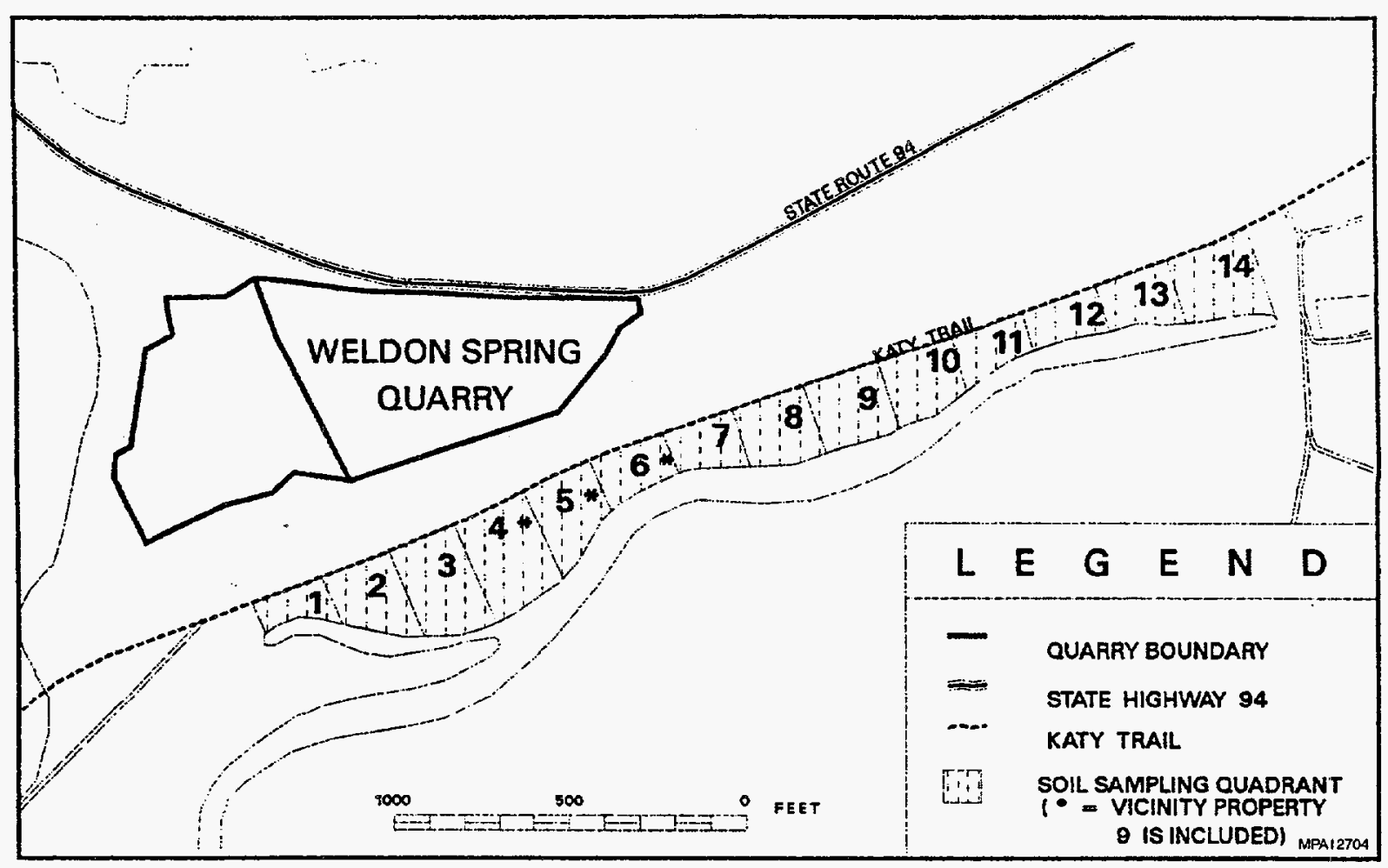

FIGURE 1.8 Surface Soil Sampling Locations Outside the Quarry Proper

few locations in the deeper intervals. Nitroaromatic contamination in soils is likely a result of groundwater transport and sorption on organic material.

\subsubsection{Femme Osage Slough and Creeks}

Surface water and sediment from the upper and lower reaches of the Femme Osage Slough, Little Femme Osage Creek, and downstream portion of Femme Osage Creek have been characterized for radiological and chemical contamination. Contaminants detected at concentrations higher than background levels in surface water in both the slough and creeks included aluminum, chromium, iron, and zinc. Uranium, sulfate, nitrate, and slightly elevated levels of arsenic, manganese, nickel, and strontium were also detected in the slough. Silver and low levels (i.e., less than $0.1 \mu \mathrm{g} / \mathrm{L}$ ) of nitroaromatic compounds were detected in surface water in the creek only. Nitroaromatic compounds were detected in Little Femme Osage Creek upgradient of the quarry; the source of this contamination is believed to be runoff from the Weldon Spring Ordnance Works area.

Contaminants elevated over background levels in slough sediment include uranium, sulfate, nitroaromatic compounds, aluminum, beryllium, cadmium, calcium, chromium, copper, magnesium, manganese, mercury, molybdenum, nickel, selenium, strontium, and vanadium. Uranium, calcium, 


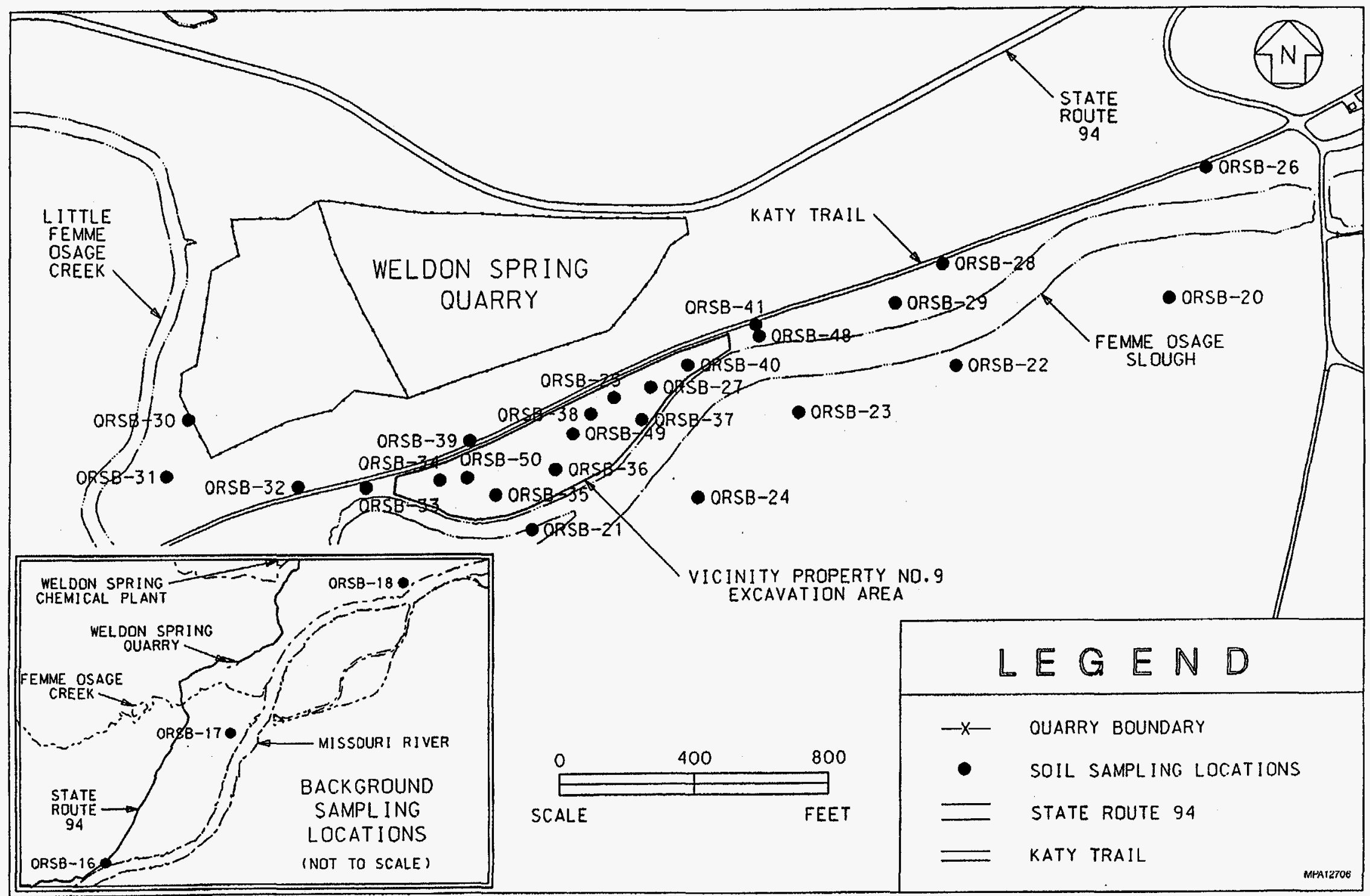

FIGURE 1.9 Background and Subsurface Soil Sampling Locations Outside the Quarry Proper 
magnesium, and strontium were also elevated in creek sediment, but in general, contaminant concentrations were lower than in the slough. An exception was antimony, which was not detected in the slough.

Possible contamination in the creek may be attributed to past site activities or flood deposition from the Missouri River. Low levels of uranium in sediment may be a result of runoff from former Vicinity Property 8. Plausible sources of contamination in the slough include groundwater seepage, runoff from Vicinity Property 9 prior to remediation, and mixing with Missouri River water. Several metals that were elevated in the creek and slough were also elevated in the river.

Fish from Femme Osage Slough were collected and analyzed to investigate any potential impacts from site contaminants. Species sampled from the slough included white and black crappie, largemouth bass, sunfish, and several bottom feeders such as bigmouth buffalo, yellow bullhead, and common carp. Fish samples were analyzed for uranium, radium, thorium, arsenic, lead, and mercury. Samples were prepared as fillets, fishcakes, and whole-body samples. Analyses indicated low-level concentrations of metals (i.e., lead, arsenic, and mercury) and uranium, similar to concentrations detected in the background samples collected from Busch Lakes 33 and 37. Radium and thorium isotopes were not detected in any samples (MK-Ferguson Company and Jacobs Engineering Group 1995; DOE 1998b).

\subsubsection{Groundwater}

Contamination of groundwater underlying the quarry area has been characterized from data collected from a network of monitoring wells. This network includes 19 wells that monitor groundwater in the bedrock system and 30 wells that monitor groundwater in the alluvium; the latter include the St. Charles County wells (see Figure 1.10). Ten years of data were evaluated in determining the nature and extent of contamination. The primary contaminants in groundwater are uranium and nitroaromatic compounds. These contaminants were likely derived from contaminated bulk wastes that were previously disposed of in the quarry. Although other contaminants were present in quarry bulk wastes, these contaminants are more soluble and were leached from the bulk wastes into the bedrock and alluvial aquifer.

Contamination in groundwater is primarily limited to the area north of the slough. Over the 10 years of monitoring, nitroaromatic compounds at concentrations greater than $1 \mu \mathrm{g} / \mathrm{L}$ have been detected in only six wells: four shallow bedrock wells and two alluvial wells located north of the slough. Uranium contamination extends from the southern margin of the quarry eastward and southward to the slough. Slightly elevated levels of uranium have been measured in one well south of the slough (RMW-2); in general, however, concentrations of uranium in wells south of the slough 


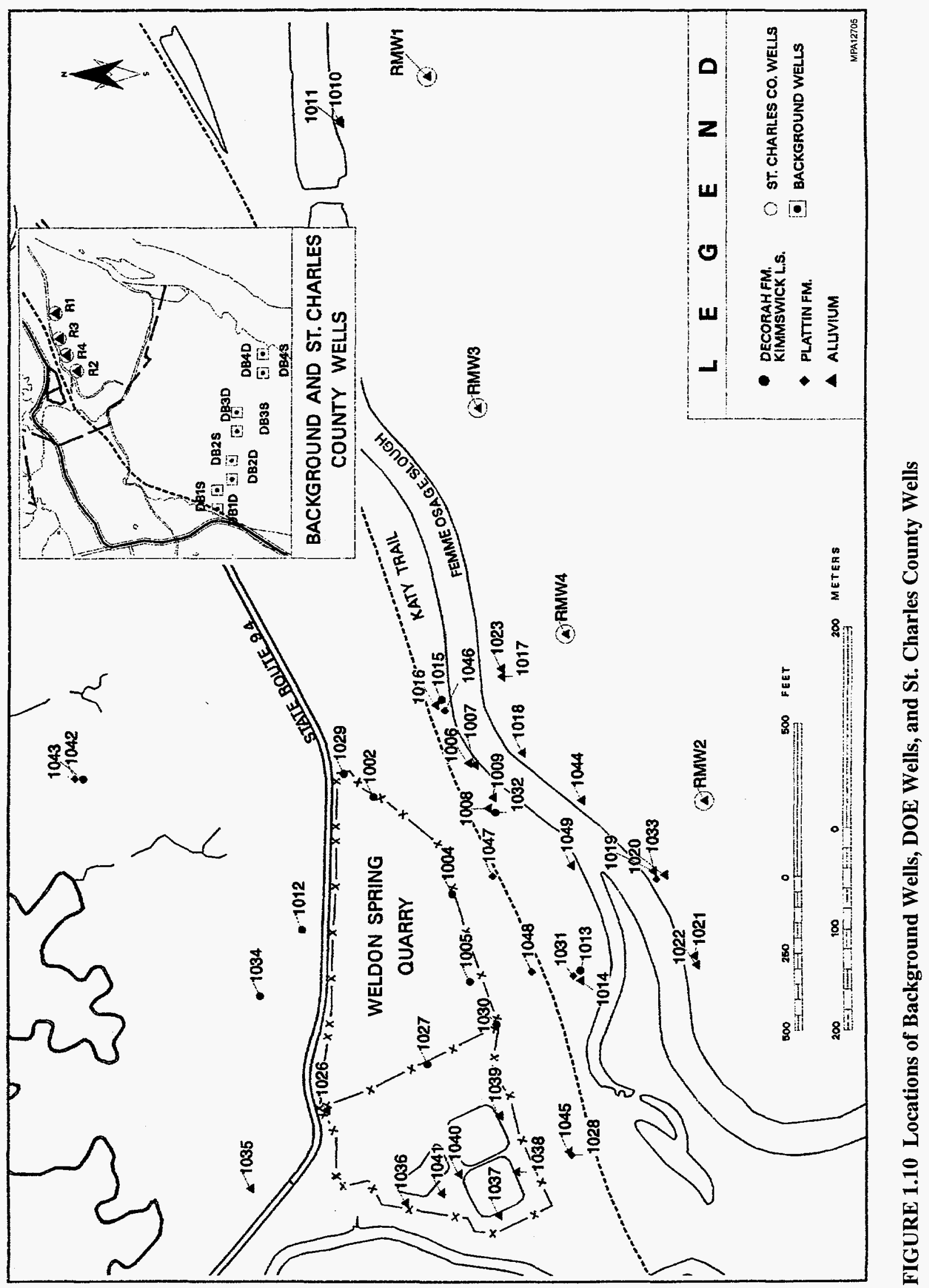


are at background levels. The highest concentrations of uranium have been detected in wells along; the southern rim of the quarry and southward in the alluvium near Vicinity Property 9. The rapid. decrease in contaminant levels in groundwater south of the slough results from the presence of a. reducing zone that degrades nitroaromatic compounds and precipitates uranium-bearing phases.

The extent of groundwater contamination has remained relatively constant over the past 10 years of monitoring (1987 to present). During this time, however, there has been a large variation in some contaminant levels resulting from bulk waste removal and the influence of major floods. Data indicate that concentrations of nitroaromatic compounds are decreasing in response to bulk. waste removal and are expected to continue decreasing in the future. The data indicate that uranium concentrations have not been influenced by quarry remediation activities, probably because of the sorption of uranium on solid aquifer material. Consequently, any decrease in uranium concentrations can be expected to occur very slowly. A few metals (e.g., aluminum, iron, manganese, and thallium) are also present in groundwater at concentrations that are elevated above background levels but are not considered to be derived from the bulk waste.

\subsection{SUMMARY OF BASELINE RISK}

Potential human health and environmental effects reflecting current conditions (postquarry bulk waste and pond water removal) and assumed future conditions at the quarry area have been. assessed to help focus cleanup decisions. The health effects were determined from radiological and. chemical doses that could result from contaminants if no additional cleanup actions were taken. A. more detailed discussion is presented in the BRA report prepared for the QROU (DOE 1998a).

\subsubsection{Human Health Assessment}

For the human health assessment, contaminants identified in the RI were subjected to an evaluation in accordance with EPA guidance in order to identify contaminants of potential concern. (COPCs) for each medium. A concentration/toxicity screen was not performed; therefore, the number of contaminants carried through the risk assessment was not limited. Table 1.1 presents the: final list of human health COPCs for the various components of the QROU.

Potential carcinogenic risks for both radiological and chemical exposures were assessed in. terms of the increased probability that an individual would develop cancer over a lifetime. The EPA. has indicated that for known or suspected carcinogens, the acceptable exposure levels for the general. public at sites on the NPL are generally concentrations that represent an excess upper-bound lifetime: cancer risk to an individual of between $1 \times 10^{-6}$ and $1 \times 10^{-4}$ (EPA 1989). This range is used as a point of reference for discussing the results of the carcinogenic risk assessment for the QROU. 
TABLE 1.1 Final List of Human Health Contaminants of Potential Concern for the QROU

\begin{tabular}{|c|c|c|c|c|}
\hline \multirow[b]{2}{*}{ Contaminant } & \multirow{2}{*}{$\begin{array}{c}\text { Quarry Proper } \\
\text { Soil and } \\
\text { Fractures } \\
\end{array}$} & \multicolumn{2}{|c|}{ Femme Osage Slough/Creeks } & \multirow{2}{*}{$\begin{array}{c}\text { Quarry } \\
\text { Groundwater }\end{array}$} \\
\hline & & Surface Water & Sediment & \\
\hline \multicolumn{5}{|l|}{ Radionuclides } \\
\hline Radium-226 & + & - & - & - \\
\hline Radium-228 & + & - & - & - \\
\hline Thorium-228 & + & - & - & - \\
\hline Thorium-230 & + & - & - & - \\
\hline Thorium-232 & + & - & - & - \\
\hline Uranium & + & + & + & + \\
\hline \multicolumn{5}{|l|}{ Metals } \\
\hline Aluminum & + & + & + & + \\
\hline Antimony & - & - & + & - \\
\hline Arsenic & - & + & - & - \\
\hline Barium & - & - & - & + \\
\hline Beryllium & - & - & + & - \\
\hline Cadmium & - & - & + & + \\
\hline Chromium & - & + & + & + \\
\hline Cobalt & - & - & - & + \\
\hline Copper & - & - & + & + \\
\hline Lead & - & + & - & - \\
\hline Manganese & - & + & + & + \\
\hline Mercury & - & - & + & + \\
\hline Molybdenum & - & - & + & - \\
\hline Nickel & - & + & + & + \\
\hline Selenium & + & - & + & - \\
\hline Silver & + & + & - & - \\
\hline Strontium & - & + & + & - \\
\hline Thallium & - & - & - & + \\
\hline Uranium & + & + & + & + \\
\hline Vanadium & - & - & + & + \\
\hline Zinc & + & + & - & + \\
\hline \multicolumn{5}{|l|}{ Organic Compounds } \\
\hline 1,3,5-trinitrobenzene & + & + & + & + \\
\hline 1,3-dinitrobenzene & + & - & + & + \\
\hline 2,4,6-trinitrotoluene & + & + & + & + \\
\hline 2,4-dinitrotoluene & + & + & + & + \\
\hline 2,6-dinitrotoluene & + & + & + & + \\
\hline Nitrobenzene & + & - & + & - \\
\hline PAHs & + & - & - & - \\
\hline PCBs & + & - & - & - \\
\hline
\end{tabular}


Potential health effects other than cancer from exposure to chemical contaminants were also assessed. The quantitative measure of noncarcinogenic health effects is the hazard index. The EPA has defined a hazard index of greater than 1 as the level of concern for noncarcinogenic health effects.

\subsubsection{Exposure Scenarios}

A recreational scenario was used to project potential human exposures to contaminants at the quarry area, primarily north of the slough and the slough itself. This scenario is consistent with current land use at the quarry area; future land use is expected to remain similar to current use. Exposure pathways evaluated for potential exposure at the quarry proper included external gamma irradiation, incidental ingestion, dermal contact, and inhalation of residual material in the cracks and crevices of the quarry walls and floor. For exposure at Femme Osage Slough, Little Femme Osage Creek, and Femme Osage Creek, the following pathways were evaluated: incidental ingestion and dermal contact with surface water and sediment, inhalation of airborne sediment particulates, and ingestion of fish (primarily from the slough).

Hazard indices and carcinogenic risks from these contaminants were estimated by using either the maximum or the $95 \%$ upper confidence limit of the arithmetic average of the data set collected for each contaminant in each media, whichever was smaller.

Under current and expected future land use, there is no contact with contaminated groundwater in the quarry area. For presentation purposes, calculations to project hypothetical residential risk from groundwater were performed to provide information regarding potential groundwater risk. Calculations were performed for each monitoring well using current data collected since 1995. The pathways evaluated included ingestion of and dermal contact with groundwater.

\subsubsection{Risk Characterization}

The results of the risk calculations for the recreational visitor at the quarry proper and Femme Osage Slough indicate that radiological and chemical risks are below or within the EPA's acceptable risk range of $1 \times 10^{-6}$ to $1 \times 10^{-4}$. Hazard indices are also less than 1 , indicating that systemic toxicity is not a concern. The estimated radiological risk is $3 \times 10^{-5}$ for the recreational visitor exposed to contaminants at the various locations (i.e., cumulative risk from exposure to contaminants at the quarry proper and at Femme Osage Slough and the creeks); this estimate incorporates multiple contaminants, multiple media, and multiple pathways. The chemical carcinogenic risk and hazard index for this recreational visitor are estimated to be $4 \times 10^{-6}$ and 0.05 , respectively. These estimates are within the EPA's acceptable risk range. Table 1.2 summarizes human health risk estimates for the quarry area. 
TABLE 1.2 Summary of Human Health Risk Estimates for the Quarry Area

\begin{tabular}{|c|c|c|c|}
\hline $\begin{array}{c}\text { Pathways } \\
\text { (Recreational Visitor) } \\
\end{array}$ & $\begin{array}{c}\text { Radiological } \\
\text { Carcinogenic Risk } \\
\end{array}$ & Hazard Index & $\begin{array}{c}\text { Chemical } \\
\text { Carcinogenic Risk }\end{array}$ \\
\hline \multicolumn{4}{|l|}{ Quarry proper } \\
\hline \multicolumn{4}{|l|}{ Soil } \\
\hline External irradiation & $1 \times 10^{-5}$ & $\mathrm{NA}^{\mathrm{a}}$ & NA \\
\hline Ingestion & $4 \times 10^{-7}$ & 0.004 & $1 \times 10^{-7}$ \\
\hline Dermal & $1 \times 10^{-7}$ & 0.0009 & $1 \times 10^{-8}$ \\
\hline Inhalation & $2 \times 10^{-9}$ & $<0.0001$ & $1 \times 10^{-12}$ \\
\hline \multicolumn{4}{|l|}{ Fractures ${ }^{b}$} \\
\hline External irradiation & $3 \times 10^{-5}$ & $\mathrm{NA}$ & NA \\
\hline Ingestion & $7 \times 10^{-7}$ & 0.008 & $6 \times 10^{-8}$ \\
\hline Inhalation & $4 \times 10^{-9}$ & $<0.0001$ & $7 \times 10^{-13}$ \\
\hline \multicolumn{4}{|l|}{ Femme Osage Slough ${ }^{\mathrm{c}}$} \\
\hline \multicolumn{4}{|l|}{ Surface water } \\
\hline Ingestion & $3 \times 10^{-7}$ & 0.003 & $9 \times 10^{-7}$ \\
\hline Dermal & $7 \times 10^{-9}$ & $<0.0001$ & $2 \times 10^{-8}$ \\
\hline \multicolumn{4}{|l|}{ Sediment } \\
\hline Ingestion & $3 \times 10^{-8}$ & 0.006 & $2 \times 10^{-7}$ \\
\hline Dermal & $1 \times 10^{-10}$ & 0.001 & $4 \times 10^{-9}$ \\
\hline Inhalation & $1 \times 10^{-10}$ & $<0.0001$ & $1 \times 10^{-13}$ \\
\hline \multicolumn{4}{|l|}{ Fish } \\
\hline Ingestion & $8 \times 10^{-9}$ & 0.03 & $3 \times 10^{-6}$ \\
\hline Total $^{\mathrm{d}, \mathrm{e}, \mathrm{f}}$ & $3 \times 10^{-5}$ & 0.05 & $4 \times 10^{-6}$ \\
\hline
\end{tabular}

a $\mathrm{NA}=$ not applicable.

b Dermal contact with soils in the fractures is assumed to be unlikely.

c Estimates for Femme Osage Slough are representative of those for Little Femme Osage Creek and Femme Osage Creek.

d Radiological carcinogenic risks were not summed with chemical carcinogenic risks because of differences in methodologies. These totals represent risks and the hazard index for the multiple pathways exposure scenario, which projects a recreational visitor who is exposed to contaminants present at the quarry area (including at the quarry proper and Femme Osage Slough).

e Ingestion of groundwater is unlikely and considered to be an incomplete pathway. Nevertheless, calculations were performed for potential risk to a hypothetical resident from ingestion of and dermal contact with groundwater (see Section 5.2.3 of the BRA [DOE 1998a]).

f External irradiation for quarry proper soil and fractures was not summed because it is not appropriate to do so; the higher of the two risks was used to calculate the total. 
Risks estimated for a hypothetical resident from ingestion of and dermal contact with contaminated groundwater ranged from $2 \times 10^{-7}$ to $6 \times 10^{-3}$ for uranium and from $1 \times 10^{-7}$ to $1 \times 10^{-4}$ for chemical contaminants. Risks greater than $1 \times 10^{-4}$ were estimated for several wells located south of the quarry and north of the slough. Hazard indexes greater than 1 were also estimated for a few wells located in this area.

On the basis of the risk assessment results presented in the BRA, none of the contaminants can be considered as contaminants of concern (COCs). However, uranium concentrations in groundwater north of the slough are high compared with both background and available regulatory benchmarks. This high concentration is significant because of its potential to migrate and affect the St. Charles County well field located downgradient.

\subsubsection{Ecological Assessment}

Femme Osage Slough and Little Femme Osage Creek are the principal habitats at the QROU, where biota can be exposed to quarry-related contaminants. A screening level assessment employing very conservative exposure scenarios was conducted for these habitats. This assessment identified current levels of aluminum, barium, manganese, and uranium in the surface water of Femme Osage Slough and Little Femme Osage Creek as posing a potential risk to aquatic biota using these habitats. Risk estimates or quotients for these contaminants were greater than 1 , indicating the potential for risk and a need for further ecological evaluations of the aquatic habitats in the slough and creek. No or low risks were identified for other contaminants in surface water at the QROU. Arsenic, cadmium, lead, manganese, mercury, nickel, and zinc are present in sediments at concentrations estimated to result in low risk to aquatic biota. No risks from nitroaromatic compounds were indicated in either medium. Modeling results indicated no risks to terrestrial wildlife receptors foraging in Femme Osage Slough or drinking from Little Femme Osage Creek.

Because screening risk estimates for several metals indicated potential risks, as discussed above, surveys of aquatic and terrestrial biota were conducted at the QROU to evaluate whether actual impacts are being incurred. The survey results indicate that the existing aquatic and terrestrial communities consist of species that would be expected to occur in the area. No impacts to abundance or species diversity of aquatic invertebrates were detected. Internal and external examinations of small mammals collected from the site failed to show any abnormalities that might indicate adverse effects from exposure to site contaminants; no impacts to abundance or biomass of small mammals were detected. Tissue analyses of fish and small mammals indicated uranium concentrations within the range reported in the literature for North America for which no adverse effects have been observed, and tissue concentrations of radionuclides in small mammals collected from the QROU were comparable to levels detected in specimens from reference sites. 
On the basis of the absence of any observable adverse effects to aquatic or terrestrial biota, the generally low levels of potential risk identified for aquatic biota, and no risks identified for terrestrial biota, the current levels of contamination in surface water and sediments from Femme Osage Slough and Little Femme Osage Creek do not appear to have affected ecological resources at these habitats and do not pose a future risk to biota at the site. Thus, remediation of these habitats is not indicated on the basis of potential ecological concerns.

\subsection{OBJECTIVES OF THE FEASIBILITY STUDY}

Remediation of any of the components of the QROU for risk reduction is not indicated on the basis of the assessment of the nature and extent of contamination, the fate and transport of contaminants, and the estimation of potential risk. However, because of the potential for uranium in quarry area groundwater north of the slough to migrate to the St. Charles County well field, the primary objective of this FS is to identify the best option for reducing or removing uranium from quarry area groundwater. This reduction is aimed at decreasing the amount of uranium that could migrate to the St. Charles County well field. A Well Field Contingency Plan (DOE 1998c) has been developed to ensure the safety of drinking water supplied to residents of St. Charles County from this well field. Any remedial actions performed for this operable unit would be integrated with pertinent aspects of this contingency plan.

The remaining components of the QROU (i.e., quarry proper, Femme Osage Slough, and creeks) have been determined not to require remediation, either from the perspective of contamination present at these components or from consideration of cumulative risk for an individual who is exposed to contaminants at the various components or areas constituting the QROU. Residual contaminant levels at the quarry proper have been determined to be at concentrations that are within the acceptable risk range of $1 \times 10^{-6}$ to $1 \times 10^{-4}$ as prescribed by the National Oil and Hazardous Substances Pollution Contingency Plan (NCP). Likewise, at Femme Osage Slough and the creeks, contaminant levels are low and do not pose unacceptable risks to human health and ecological receptors.

Groundwater at the quarry area is not currently used, and future use is unlikely. The low permeability of the alluvial aquifer where contamination exists is expected to serve as a natural detriment to groundwater usage in the area. The low pump rates and low yields would not be expected to support any sustained human use of the groundwater.

Although migration of uranium to the existing county well field is possible and could be occurring (probably at very low rates), the impact from this migration is not indicated from monitoring data obtained from wells south of the slough, with the exception of one well (RMW-2). Ten years of monitoring data from wells south of the slough, including the production wells in the well field, have yielded uranium concentrations similar to background. Data from RMW-2 have 
consistently been slightly greater than background since its placement (average of $6 \mathrm{pCi} / \mathrm{L}$, maximum of $10 \mathrm{pCi} / \mathrm{L}$, as compared to a background value of 2.77 that was statistically determined for the QROU). Natural levels of uranium at nearby (off-site) areas have been measured to be similar or higher than the background level established for the QROU and those of RMW-2. For example, at Darst Bottoms, a maximum value of $14 \mathrm{pCi} / \mathrm{L}$ has been identified.

\subsection{REMEDIATION GOALS FOR QUARRY GROUNDWATER}

The primary remediation goal for the $\mathrm{QROU}$ is to reduce the amount of uranium currently located in quarry area groundwater north of the slough, thereby reducing the amount of uraniurn that could potentially migrate to the St. Charles County well field.

Current concentrations in three monitoring wells slightly exceed the applicable or relevant and appropriate requirement (ARAR) of $0.11 \mu \mathrm{g} / \mathrm{L}$ for 2,4-DNT. Current data indicate that the ARAR of $17 \mu \mathrm{g} / \mathrm{L}$ for nitrobenzene is not exceeded. Current data also indicate that there is only one exceedance of the $1.0 \mu \mathrm{g} / \mathrm{L}$ standard for 1,3-dinitrobenzene. A maximum concentration of $3.5 \mu \mathrm{g} / \mathrm{L}$ was reported for one well. This data point could be an anomaly because in this same sample, other parameters that were analyzed were also higher than typically reported for this well.

No federal or state maximum contaminant level (MCL) or maximum contaminant level goal (MCLG) exists for uranium in drinking water. In 1991, the EPA published a proposed rule setting an MCL for uranium at $20 \mu \mathrm{g} / \mathrm{L}$ (EPA 1991). The proposed MCL corresponds to $14 \mathrm{pCi} / \mathrm{L}$ for the activity concentration ratio of uranium isotopes found in the groundwater at the quarry area. However, this proposed rule has never been finalized and, therefore, cannot be an applicable or relevant and appropriate requirement (ARAR). The proposed rule may be a "to-be-considered" (TBC) requirement that can be used to assist in the formulation of goals for groundwater in the quarry area. It should be noted that MCLs and MCLGs apply to the concentrations at the point at which the water is consumed (that is, at the tap); they are not applicable to contaminated groundwater in environmental settings, such as at the quarry area.

In 1995, the EPA promulgated a final rule for groundwater standards for remedial actions at inactive uranium processing sites (Title 40, Part 192, of the Code of Federal Regulations [40 CFR Part 192]). Although the rule is applicable only at 24 specified inactive uranium processing sites, it may be considered relevant and appropriate to the actions being evaluated in the FS. The NCP sets out a process to determine if a standard is relevant and appropriate to a particular remediation activity or site. The $30 \mathrm{pCi} / \mathrm{L}$ standard is relevant in that it applies to the same contaminant (uranium) in the same medium (groundwater). However, this standard was developed for environmental conditions that are not pertinent to the quarry area. As such, it is questionable if this standard is appropriate as applied to contaminated groundwater in the quarry area. 
The $30 \mathrm{pCi} / \mathrm{L}$ standard for contaminated groundwater at the 24 designated inactive uranium processing sites being addressed under 40 CFR Part 192 was promulgated on the basis of the proposed drinking water standard for uranium (discussed above) for sites generally located in arid regions of the western United States where water is a scarce resource. The cost of remediating contaminated groundwater at these sites to drinking water standards was deemed to be justified by the EPA due to the general lack of readily available alternative sources of potable water. This is not the case for the quarry area, given the proximity of the Missouri River. As such, this standard may not be well suited to conditions at the quarry area.

Even though the appropriateness of the $30 \mathrm{pCi} / \mathrm{L}$ standard for quarry area groundwater is questionable, it does provide a metric for evaluating remedial action alternatives in the FS. This standard was promulgated by the EPA for contaminated groundwater at inactive uranium mill tailings sites to provide an adequate margin of safety against both carcinogenic and systemic toxicity effects of uranium in groundwater. It is equivalent to a risk level of approximately 1 in 100,000, should this water be consumed at a rate of $2 \mathrm{~L} /$ day for 350 days per year over a period of 30 years. The average high concentration of uranium north of the slough is estimated to be approximately $2,800 \mathrm{pCi} / \mathrm{L}$. Modeling of uranium transport in groundwater from the area north of the slough to the nearest production well indicates that the uranium concentration would be reduced to approximately $21 \mathrm{pCi} / \mathrm{L}$, which is less than the metric of $30 \mathrm{pCi} / \mathrm{L}$ (DOE 1998a). Hence, this standard would be met with no remedial action on the contaminated groundwater in the quarry area at the well field.

As noted previously, the remediation goal for the QROU is to reduce the amount of uranium that could potentially migrate to the St. Charles County well field. This remediation goal will be achieved by removing as much uranium from this groundwater as is reasonably possible by use of standard engineering approaches. No remediation is warranted on the basis of current or hypothetical future risks from exposure to nitroaromatic compounds in quarry groundwater. This is supported by the fact that concentrations of nitroaromatic compounds have decreased significantly since bulk waste removal and only a few concentrations slightly exceed Missouri water quality standards. Further, these concentrations are expected to continue to decrease over time. A detailed discussion of ARARs is presented in Appendix A.

\subsection{ORGANIZATION OF THE REPORT}

The process discussed in this FS is expected to provide the information necessary to support a decision for the quarry area groundwater. The report is organized as follows:

- Chapter 2 identifies and evaluates potential response technologies applicable to groundwater remediation;

- Chapter 3 develops and screens preliminary alternatives; 
- Chapter 4 describes and evaluates the final alternatives in detail;

- Chapter 5 presents a comparative analysis of the final alternatives;

- Chapter 6 lists all references cited in this report;

- Appendix A lists and discusses the regulatory requirements potentially applicable or relevant and appropriate to the remedial action;

- Appendix B discusses the required operational period of the interceptor trench concept;

- Appendix $\mathrm{C}$ discusses the bed thickness and operational duration of the in-situ permeable barrier for Alternative 5;

- Appendix D describes the analytical methodologies used to address environmental impacts for Alternative 2;

- Appendix E describes the methodology and assumptions used to determine the costs of the various alternatives considered in this FS; and

- Appendix F presents data regarding distribution coefficients collected from the quarry area. 


\section{IDENTIFICATION AND SCREENING OF TECHNOLOGIES}

\subsection{SCREENING CRITERIA}

The criteria for identifying potentially applicable technologies are provided in EPA guidance (EPA 1988a) and in the NCP (EPA 1990a). The primary requirements for a final remedy are that it be both protective of human health and the environment and cost effective. Hence, technology screening focuses on these two factors. Additional selection criteria include the following:

- Preferred remedies are those in which the principal element is treatment to permanently or significantly reduce the toxicity, mobility, or volume of hazardous substances, pollutants, or contaminants;

- Where practical treatment technologies are available, off-site transport and disposal without treatment is the least preferred alternative; and

- Permanent solutions and alternative treatment technologies or recycle/resource recovery technologies should be assessed and used to the maximum extent practicable.

These criteria were considered in identifying and screening technologies to determine the appropriate components of remedial action alternatives for the contaminated groundwater from the QROU at the Weldon Spring site. Protection of human health and the environment was the primary consideration for determining how the contaminated groundwater should be managed.

The COC for consideration in this FS is uranium (see Chapter 1). However, low levels of nitroaromatic compounds, the other primary contaminants found in the quarry bulk waste, have been detected in the groundwater. Even though the concentrations of these compounds have decreased in response to bulk waste removal from the quarry and are expected to continue decreasing, the technologies considered for removal of uranium from extracted groundwater must necessarily include technologies that address these nitroaromatic compounds.

On the basis of current knowledge of the nature and extent of groundwater contamination at the quarry area, general response actions that could be implemented to help reduce exposure to the contaminants or to reduce or remove elevated concentrations of uranium and nitroaromatic compounds are (1) institutional controls and monitoring; (2) natural processes; (3) in-situ containment; (4) in-situ treatment; or (5) removal, storage, ex-situ treatment, and disposal. Technology types and process options that could be used to implement each general response action ( 3 through 5) are presented schematically in Figure 2.1. Specific application of these technology 


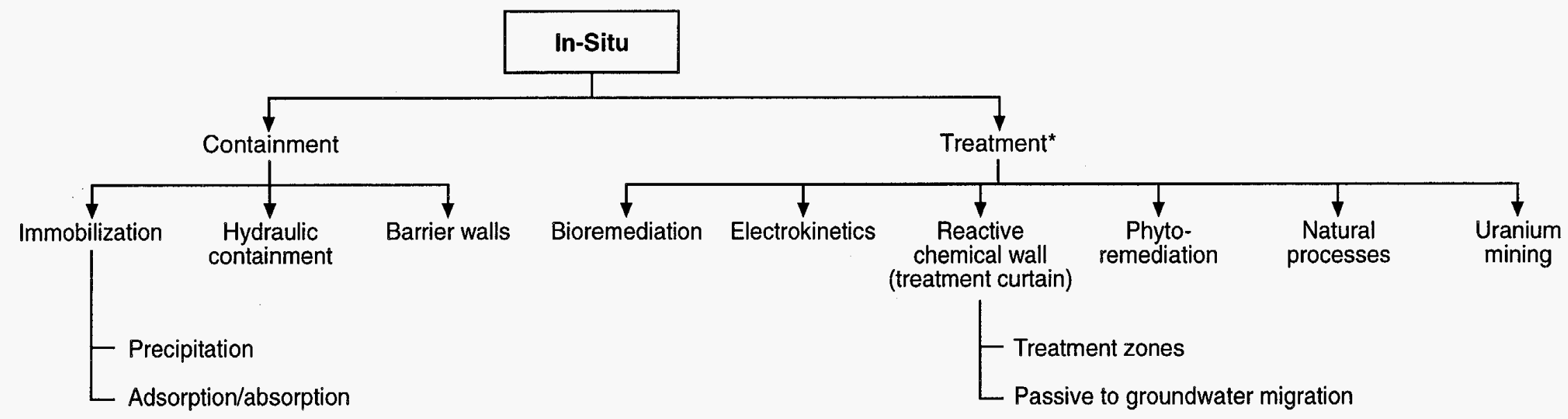

*Most in-situ treatment approaches require injection of materials into the aquifer; some may require subsequent removal of contaminant.

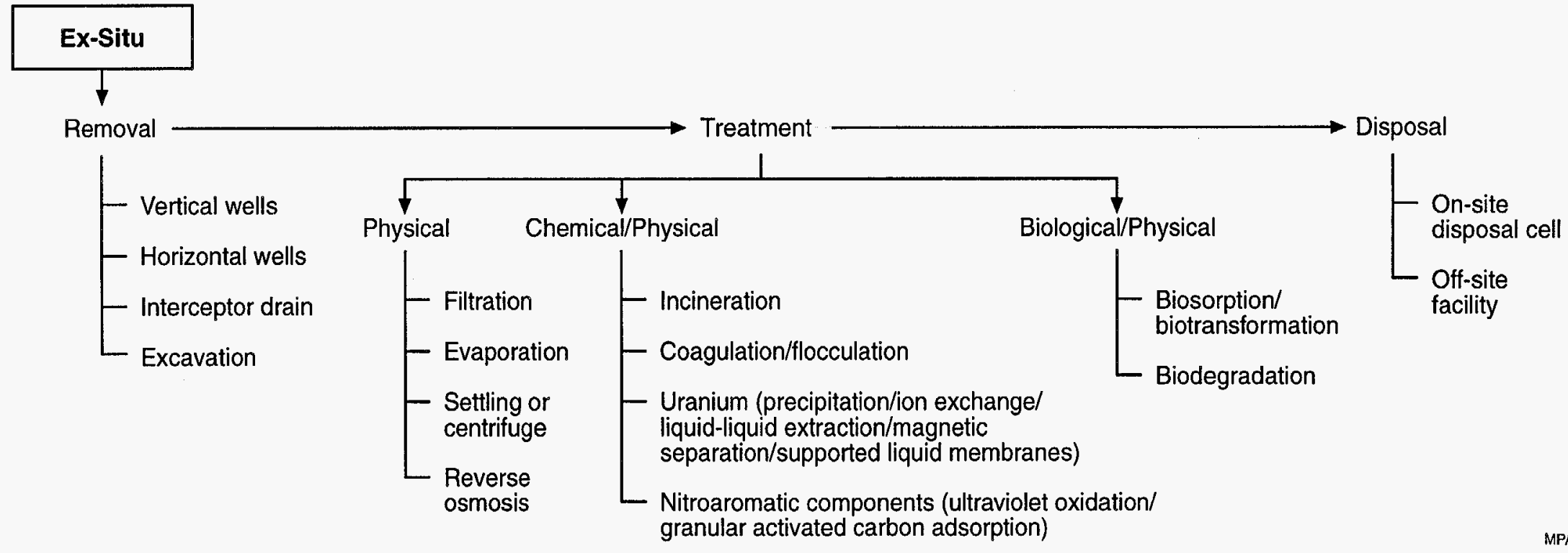

FIGURE 2.1 Potential Treatment Technologies for Groundwater Remediation of the QROU at the Weldon Spring Site 
types and process options to conditions at the quarry area was evaluated to determine which would be most appropriate for groundwater remediation. These technologies were screened on the basis of effectiveness, implementability, and cost, defined as follows:

- Effectiveness - in terms of protecting human health and the environment in both the short term and the long term; minimizing toxicity, mobility, or volume; complying with ARARs; and achieving protection in a reasonable time frame;

- Implementability - in terms of technical feasibility, resource availability, and administrative feasibility; and

- Cost - in terms of comparing costs (i.e., low, moderate, or high) for both the short term (capital) and long term (operation and maintenance [O\&M]).

\subsection{TECHNOLOGY IDENTIFICATION AND SCREENING}

\subsubsection{Institutional Controls and Monitoring}

Institutional controls are measures that preclude or minimize public exposure by limiting access to or use of contaminated groundwater. Institutional controls include measures to restrict access such as security guards and use or deed restrictions. These measures do not reduce contaminant toxicity, mobility, or volume, but they can reduce the potential for human exposure to the contaminated groundwater. Institutional control measures that apply solely to groundwater, such as groundwater restrictions, may be used to prohibit or limit the drilling of wells for the purpose of groundwater consumption. Monitoring is a measure that provides supporting information regarding contaminant concentrations and the need for maintaining or implementing institutional controls while remedial response actions are being carried out.

The screening analysis for institutional controls and monitoring is summarized in Table 2.1. On the basis of effectiveness, implementability, and cost, all of these measures have been retained for further consideration.

\subsubsection{Natural Processes}

Naturally occurring processes can contribute to cleaning up groundwater and soil contaminated with various toxic and hazardous materials. With time, these processes gradually reduce the hazards of contamination. Two types of natural processes can be considered; physical/chemical 
TABLE 2.1 Summary of Screening Analysis for Institutional Controls and Monitoring

\begin{tabular}{llll}
\hline $\begin{array}{l}\text { Institutional } \\
\text { Control Measure }\end{array}$ & \multicolumn{1}{c}{ Effectiveness } & \multicolumn{1}{c}{ Implementability } & Cost \\
\hline $\begin{array}{l}\text { Groundwater access } \\
\text { restrictions }\end{array}$ & $\begin{array}{l}\text { The area where groundwater contamination } \\
\text { is highest could be restricted by imposing } \\
\text { barriers, such as well caps, which could } \\
\text { control exposures to contaminated } \\
\text { groundwater }\end{array}$ & $\begin{array}{l}\text { Access restriction measures would } \\
\text { be easy to implement and } \\
\text { resources would be readily } \\
\text { available. }\end{array}$ & Low \\
$\begin{array}{l}\text { Ownership and land } \\
\text { use conditions }\end{array}$ & $\begin{array}{l}\text { DOE has accountability for as long as } \\
\text { contamination is present. This measure } \\
\text { would permit the control of public } \\
\text { exposures to on-site contamination by } \\
\text { restricting access and use. The state owns } \\
\text { the surrounding wildlife areas, and recrea- } \\
\text { tional use would not include groundwater } \\
\text { use. }\end{array}$ & $\begin{array}{l}\text { Ownership and use or deed restric- } \\
\text { tions would be easy to implement, } \\
\text { and resources would be readily } \\
\text { available. }\end{array}$ & Low \\
Monitoring & $\begin{array}{l}\text { An extensive groundwater monitoring } \\
\text { program is in place at the site. This measure } \\
\text { could support the mitigation of potential } \\
\text { exposures by providing data on the extent } \\
\text { of contamination and the effectiveness of } \\
\text { primary control measures such as contain- } \\
\text { ment or removal. }\end{array}$ & $\begin{array}{l}\text { Monitoring would be easy to } \\
\text { implement; the existing monitoring } \\
\text { network could be used to provide } \\
\text { long-term protection. }\end{array}$ & Low \\
\hline
\end{tabular}

processes whereby the contaminant concentration would be reduced through chemical or physical means and biological processes whereby the contaminant would be broken down or absorbed by microbes or plants.

The first classification includes a number of processes such as oxidation-reduction reactions, absorption, adsorption, and dilution of the contaminant concentrations. Biological processes, the second classification, includes two broad categories, accumulation and degradation by microbes and accumulation and degradation by plants.

The migration of uranium, the principal contaminant in the groundwater at the quarry area, toward the Missouri River is primarily dependent upon the flow rate of groundwater in the aquifer and the types of materials present in the aquifer. Except for a monitoring well in the Plattin Limestone (MW-1031), concentrations of uranium have remained below maximum detected levels since the original source of uranium (bulk waste) was removed from the quarry (DOE 1998b). At least one of the natural processes mentioned above is responsible for the slow reduction with time of the uranium concentration in other locations within the aquifer. 
Water movement in the groundwater system between the quarry and the slough occurs primarily through fractured limestone and low-porosity alluvium in a southerly direction toward the Missouri River. The rate of uranium transport is very slow through this region. Wells in this area generally produce less than $4 \mathrm{~L} / \mathrm{min}$ ( $1 \mathrm{gpm}$ ) maximum due to the low permeability of the aquifer. Concentrations of uranium in the groundwater are expected to continue to slowly diminish over time through dilution because the contaminant source at the quarry has been removed. The primary groundwater recharge source is infiltration from rainwater and runoff, which provides a clean source of water to dilute the contaminant concentrations in the aquifer.

Monitoring data obtained to date could be interpreted as indicating that the farthest extent from the quarry of the migrating uranium contamination in the groundwater is the approximate location of the slough. This potential coincidence could be because this region contains large amounts of decaying organic matter. Groundwater with decaying organic matter maintains a reducing condition for many metals, including uranium. Oxidation-reduction (redox) reactions of uranium may become important near the slough. Upon reaching the reducing conditions near the slough, soluble uranium (uranium VI) in the groundwater would be reduced to the +4 state (uranium IV). Uranium in the +4 state forms uranium dioxide $\left(\mathrm{UO}_{2}\right)$, which is highly insoluble and would precipitate out of solution. Thus, these redox conditions could be responsible for the behavior of uranium ions near the slough.

Another interpretation of the monitoring data suggests that uranium contamination has already migrated south of the slough, and that the reduced uranium concentration south of the slough is due to dilution. The coarse-grained composition of the alluvium in the aquifer south of the slough has a much higher permeability than is found in the fine-grained alluvium in the aquifer north of the slough. This disparity in permeability permits larger volumes of uncontaminated groundwater originating from local runoff and the Missouri River to mix with smaller volumes of groundwater originating in the fine-grained alluvium of the aquifer north of the slough.

The sorption process could also play a role in determining what happens to uranium near the slough. Sorption of the contaminant refers to the tendency of these molecules to be bound to the surface (adsorption) of and to internal sites (absorption) in the bulk solid phase of the aquifer. Sorption is expected to occur primarily in the upper portion of the alluvial aquifer because of the higher proportion of clay, humic material, and iron-manganese hydroxides.

Two parameters are important in describing this interaction between the contaminant and the solid phase (soil). The total sorption capacity is proportional to the total number of available sorption sites. When all of the sorption sites are occupied, the sorption capacity is exhausted and contaminant concentrations are no longer attenuated as the groundwater passes through the solid phase. A second parameter of importance is the strength of the binding between the contaminant and the sites in or on the solid phase. This strength is related to the value of the distribution coefficient $\left(\mathrm{K}_{\mathrm{d}}\right) . \mathrm{K}_{\mathrm{d}}$ values are specific to a given contaminant in relation to a particular type of soil. 
Understanding the movement of a given contaminant through an aquifer depends in part on knowing the $K_{d}$ values for each soil type and the groundwater flow conditions.

Any of these three mechanisms - dilution, redox reduction, or sorption - or some combination of them may be responsible for the low uranium groundwater concentrations south of the slough. The relative importance of these mechanisms is significant because they affect the behavior of uranium differently with time and changing conditions. If there is little uranium in the solid-phase material, the uranium concentrations in groundwater will diminish over time as dilution occurs. On the other hand, if larger quantities of uranium are present in the soil material, groundwater concentrations may stay elevated in the same area for a much longer time because of the potential for continued release of uranium (i.e., dissolution or desorption) from these aquifer materials.

Biological processes could also be occurring in the quarry area. Accumulation or precipitation of uranium by microbes (Barton et al. 1996) and accumulation by vegetation (Cooney 1996) are possible. The area around the slough provides an excellent setting for such microbial action and vegetative growth.

The screening analysis for natural processes is summarized in Table 2.2. On the basis of this evaluation, natural processes have been retained as potentially applicable to attenuating contaminant concentrations in groundwater.

\subsubsection{In-Situ Containment}

In-situ (in-place) containment consists of technologies that confine contaminated groundwater at its current location. In-situ containment technologies include the erection of barrier walls, hydraulic containment, or the immobilization of a contaminant species at its current location. These technologies reduce contaminant mobility and the associated potential for exposure, but, except for one variation of hydraulic containment, they do not reduce contaminant toxicity or volume.

\subsubsection{Barrier Walls}

A physical barrier placed immediately to the north or south of the slough could halt migration of the contaminated groundwater toward the St. Charles County well field. Construction of such a barrier would entail digging to a depth of approximately $10 \mathrm{~m}(30 \mathrm{ft})$ over a distance of approximately $610 \mathrm{~m}(2,000 \mathrm{ft})$. Trenching equipment currently available can routinely achieve such depths. The barrier itself could be composed of heavy plastic sheeting, sheet piling, or a slurry wall. 
TABLE 2.2 Summary of Screening Analysis for Natural Processes, In-Situ Containment, and In-Situ Treatment Measures

\begin{tabular}{ll} 
In-Situ Measure & \multicolumn{1}{c}{ Effectiveness } \\
\hline Natural processes & $\begin{array}{l}\text { Groundwater concentrations of uranium and nitro- } \\
\text { aromatic compounds are expected to slowly diminish } \\
\text { over time due to dilution because the contaminant } \\
\text { source at the quarry (i.e., bulk waste) has been } \\
\text { removed. The primary groundwater recharge source is } \\
\text { infiltration from rainwater and runoff, which provides } \\
\text { a clean source of water to dilute the contaminant } \\
\text { concentrations in the aquifer. It might be difficult to } \\
\text { show its effectiveness in the near term. }\end{array}$
\end{tabular}

Physical barrier A physical barrier — such as a slurry wall or plastic sheeting - can effectively reduce lateral migration. The barrier would act to confine contamination to the currently affected areas but would not lower the contaminant concentrations.

Hydraulic containment

Immobilization Immobilization of uranium through either precipitation or adsorption/absorption would effectively remove uranium from the groundwater.

Bioremediation

Microorganisms could be used to generate a reducing environment that would result in precipitation (immobilization) of the uranium.

Electrokinetics

Underground electrodes cause preferential migration of chemical species in the aquifer to treatment zones at or around electrodes. The effectiveness of remediation for uranium is not well established.

Uranium mining

In-situ uranium mining requires the injection of lixiviants into the aquifer to release the uranium from bound sites. If not properly controlled, release of the uranium could result in higher groundwater concentrations migrating from the contaminated area.

Reactive wall
A permeable barrier is placed across the contaminated groundwater flow path. The barrier contains species that either react with the contaminant to remove it from solution or catalyze its breakdown. A number of materials have been identified that are capable of removing uranium from groundwater.

Natural processes are already occurring and are expected to continue.

Could be implemented by conventional methods and equipment.

Could not be implemented because of the aquifer's sloping base and the low and contrasting permeabilities found within the aquifer.

Could not be implemented because of the low permeability of the aquifer and uncertainties in the chemical makeup of the aquifer.

Could not be implemented because the low permeability of the aquifer precludes injection of the microorganisms and their feed. Also, these materials cannot be delivered uniformly because of the heterogeneous nature of the aquifer.

Could be implemented by conventional methods and equipment.

Could not be implemented because of the low permeability of the aquifer, nonuniform delivery of the materials, and uncertainties in the chemical makeup of the aquifer.

Could be implemented by conventional methods and equipment.

\section{Cost}

\section{Low}

Low to moderate

Low to moderate

Low to moderate

Moderate

Moderate to high

Moderate

Moderate to high 
TABLE 2.2 (Cont.)

\begin{tabular}{lll}
\hline In-Situ Measure & \multicolumn{1}{c}{ Effectiveness } & Implementability \\
\hline Phytoremediation & $\begin{array}{l}\text { Vegetation is used to preferentially absorb contaminant } \\
\text { materials from the soil and either break down the } \\
\text { contaminant or retain it in their biomass. Initial studies } \\
\text { have shown that the measure is effective with uranium, } \\
\text { but only in near-surface layers. }\end{array}$ & $\begin{array}{l}\text { Could not be implemented to a depth } \\
\text { of approximately 10 m (30 ft) in the } \\
\text { short term. }\end{array}$ \\
\hline
\end{tabular}

Although the barrier would stop contaminant migration, the barrier itself would have to be maintained indefinitely because it is not a technology that reduces the amount of contamination present. A bottom seal on the contaminated upper aquifer is not necessary because there is little: vertical hydraulic connection between it and the underlying Plattin Limestone.

\subsubsection{Hydraulic Containment}

Hydraulic containment of a contaminant in an aquifer can be achieved through the use of: pumping wells, injection wells, or a combination of the two (EPA 1996b). Hydraulic containment: is also the primary objective of pump-and-treat systems. Further discussion of groundwater removal. for application in pump-and-treat systems can be found in Section 2.2.5.

The hydraulic control exerted by a vertical pumping well relies on the creation of a capture zone where water is drawn toward the well. A line of wells with overlapping capture zones can be situated downgradient of the contamination to form a barrier to further migration. A different type of barrier to migration, a pressure ridge, can also be formed by injecting uncontaminated water through a series of injection wells. The resulting increase in hydraulic pressure prevents groundwater from flowing along its original path. Pressure ridges are often used in conjunction with pump-andtreat systems; the treated water extracted from within the contaminated area is used for injection (EPA 1996b).

Problems with both types of hydraulic barriers are encountered in heterogeneous media such as the aquifer materials in the region between the quarry and the slough. The contrasts in permeability found in the aquifer materials preclude the establishment of a uniform capture zone or a uniform pressure ridge, thereby introducing the potential for contamination to pass between two neighboring wells and resulting in loss of containment. Creating a proper capture zone in this area. may also be problematic because of the low permeability and the sloping aquifer base (Cohen et al. 1994). 


\subsubsection{Immobilization}

Immobilization of the uranium or nitroaromatic compounds in-situ relies on either chemical reaction (precipitation of the dissolved uranium out of solution or degradation of the nitroaromatic compounds) or binding of the contaminants through adsorption or absorption by an immobile solidphase material within the groundwater aquifer. Either immobilization process, chemical reaction or binding, requires the injection of materials into the aquifer. The low permeability of the aquifer makes pumping materials into it impractical. Also, if an injection technology were attempted, the injected materials could not be effectively distributed because of the contrasting permeabilities found within the aquifer. This is the same problem encountered when considering hydraulic containment (Section 2.2.3.2). Second, even if the injected materials could be effectively and evenly distributed, this could actually cause the release of contaminants such as uranium. The slow migration of the uranium over time may be in part due to immobilization of the contaminant by aquifer material, which might preferentially release the uranium for injected material. The use of injection technology is, therefore, highly questionable because of the inability to uniformly inject materials into the aquifer, and because the chemistry of the groundwater aquifer is not well understood.

\subsubsection{Summary}

The screening analysis for in-situ containment is summarized in Table 2.2. The technology of a physical barrier has been retained as potentially applicable to a groundwater remedial action. On the basis of implementability, hydraulic containment and in-situ immobilization were rejected from further consideration for groundwater remediation at the Weldon Spring site primarily because of the low and contrasting permeabilities of the aquifer material.

\subsubsection{In-Situ Treatment}

In-situ treatment consists of technologies that treat the groundwater in place and generally remove or break down the contaminants in some form. The main advantage of in-situ treatment is that such technologies allow groundwater to be treated without being brought to the surface, which could result in large cost savings. The main disadvantage of these technologies is usually a longer treatment period and difficulty in verifying how well the process is working, especially in aquifers with a nonuniform environment. The technologies considered for this analysis included bioremediation, electrokinetics, reactive walls, in-situ uranium mining, and phytoremediation. 


\subsubsection{Bioremediation}

Bioremediation involves the use of microorganisms to produce a reducing environment that would result in precipitation of the dissolved uranium as $\mathrm{UO}_{2}$. Bioremediation of groundwater at the quarry area could not be readily implemented because of the difficulty of injecting materials (the microorganisms and their feed) into the aquifer (see Section 2.2.3).

\subsubsection{Electrokinetics}

Technologies involving electrokinetics rely on the transport phenomena associated with the application of a direct current between implanted electrodes in porous media. These phenomena include electrophoresis (movement of a charged particle or colloid in an electric field), electromigration (movement of solute ions in an electric field), and electroosmosis (movement of water in response to an electric field). Once the contaminants reach an electrode, they can be extracted to a recovery system (ex-situ treatment), treated (complexed with ion-exchange resins), or deposited (precipitated, adsorbed, or electroplated) at the electrode. A few laboratory studies have been conducted to assess the feasibility of using electrokinetics to remediate uranium contamination (Bibler et al. 1992, Acar et al. 1993, Turney et al. 1994, EPA 1995, Booher et al. 1997), but no completed pilot or field studies have yet been reported in the United States. Bench-scale testing would likely be required before electrokinetics would be applied to a site in order to optimize the removal process, due to the technology's dependence on several compositional (chemical makeup) and environmental (e.g., water content, soil homogeneity) variables.

Electrokinetics might not be readily implementable because of the low contaminant concen-

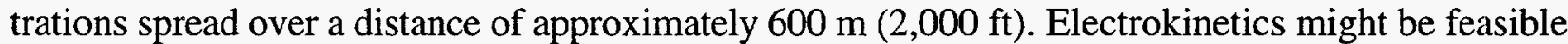
and implementable if localized areas of higher contaminant concentrations were to be treated, or if an electrokinetic "wall" was erected across the path of groundwater migration, similar in concept to the reactive wall discussed in Section 2.2.4.3. However, electrokinetic remediation of uraniumcontaminated sites is not yet a proven technology, and because of the contaminated aquifer's heterogeneity and low permeability, it would be difficult to follow its progress if attempted.

\subsubsection{Reactive Walls}

A technological alternative to erecting a physical barrier to halt the migration of contaminated groundwater would be the use of a reactive chemical wall in its place. Barrier walls would be erected to funnel the flowing groundwater into treatment zones where the contaminants would be extracted. Another variation of the reactive wall concept would be construction of a wall composed of material with an affinity for the contaminant, either one of reaction or absorption. As the groundwater passed through this more passive chemical wall (permeable treatment wall) during 
natural migration through the aquifer, the contaminant would be preferentially removed from the groundwater.

Implementation of a reactive wall technology to remove uranium might be feasible because a number of materials are capable of removing uranium from groundwater (Vidic and Pohland 1996). Such an effort would require further characterization of the chemical systems operating in the aquifer, and like the physical barrier discussed in Section 2.2.3, the reactive wall would have to be maintained indefinitely because of the low flow rate of the groundwater in the aquifer.

The use of a reactive wall with treatment zones where contaminant extraction would occur is not warranted, because these zones would have to be maintained indefinitely to treat small amounts of groundwater with low levels of contamination until contaminant concentrations in the groundwater decreased below some specific value. A conservative estimate of the total rate of groundwater flow through the entire cross-section of the aquifer where the wall would be located is about $200 \mathrm{~L} / \mathrm{min}$ (50 gpm) maximum (see Appendix B). The alternative, a passive chemical wall, could be constructed, left to filter the groundwater, and monitored periodically. If the wall material were to reach saturation levels with the contaminant, the existing barrier could be excavated, disposed of at a permitted facility, and replaced with fresh material.

\subsubsection{In-Situ Uranium Mining}

In-situ uranium mining would involve the injection of lixiviants into the aquifer to release uranium bound to material in the aquifer. Application of this technology to the contaminated area is highly questionable. The low permeability of the aquifer could cause problems such as fouling of the injection wells, and the heterogeneous nature of the aquifer would preclude uniform delivery of the lixiviants. The chemistry of the aquifer material is also not well understood; therefore, selection of the proper lixiviant could be problematic. A long interceptor trench would be required to ensure that the majority of the injected and released material is recovered (see Section 2.2.3.2 on hydraulic containment).

\subsubsection{Phytoremediation}

Phytoremediation is a recently recognized technology that uses vegetation (plants) to extract contaminants from soil and groundwater in-situ. The process can be applied to metals contamination through extraction or stabilization. Organic compounds are remediated through degradation or extraction. Application of phytoremediation is dependent upon the depth of the contamination and the selection of plant species appropriate to the contamination, cleanup standard, and climate. 
One aspect of phytoremediation is exploitation of the enhanced microbial populations that coexist with a plant's root system (the rhizosphere). Within the rhizosphere, plants contribute the carbonaceous substrate and oxygen transfer for in-situ biodegradation. Rhizodeposition is partially the result of the decay of dead roots and root hairs. Also important to the process are root exudations, such as leakage from epidermic cells, secretions resulting from metabolic activity, mucilage from root tips, and lysates from sloughed cells. This resultant carbonaceous material stimulates overall bacterial activity and provides substrate for cometabolic degradation of xenobiotic hydrocarbons.

The dominant active mechanism for phytoremediation of metals such as uranium is phytoextraction into the tissue of the plant. The mechanism for metal accumulation includes chelation, precipitation, compartmentalization, and translocation. To successfully apply this technology to a site contaminated with metals, the $\mathrm{pH}$, organic complexes, and interfering elements must be assessed, and the plant species used must have the appropriate metal selectivity. In some instances, it may be necessary to apply soil amendments to enhance the process.

Application of phytoremediation to removing uranium is promising. However, a depth limitation of approximately $3 \mathrm{~m} \mathrm{(10} \mathrm{ft)} \mathrm{(Miller} \mathrm{1996b)} \mathrm{precludes} \mathrm{its} \mathrm{use} \mathrm{for} \mathrm{remediation} \mathrm{of} \mathrm{the}$ groundwater south of the quarry, where contamination has been detected at depths of approximately $10 \mathrm{~m}$ (30 ft). Other issues also need resolution, such as the relatively long times necessary to reach remediation goals, subsequent handling and disposition of accumulated biomass, the securing of plants from other bioaccumulators (wild fauna), and the introduction of nonnative plants for phytoremediation (Negri and Hinchman 1996).

\subsubsection{Summary}

The screening analysis for in-situ treatment is summarized in Table 2.2. On the basis of implementability, bioremediation was not retained for further consideration for groundwater remediation at the quarry area because of the inability to inject materials into the aquifer and the lack of uniform delivery of the materials. Electrokinetics was rejected on the grounds of implementability (too large an area requiring remediation) and effectiveness (lack of data on uranium recovery). The technology of a passive chemical wall has been retained as potentially applicable to addressing groundwater contamination. In-situ uranium mining was rejected on the basis of implementability (inability to inject materials into the aquifer and nonuniform delivery) and effectiveness (the chemical balances in the aquifer are not well understood). Phytoremediation was rejected as a remediation technology on the basis of implementability (the technology is limited to an effective

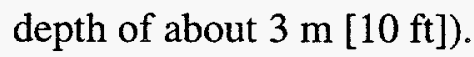




\subsubsection{Removal of Groundwater from the Aquifer}

If an ex-situ groundwater remediation strategy is used, the contaminated groundwater must first be extracted from the aquifer. The groundwater removal technologies investigated for the quarry area include vertical wells, horizontal wells, interceptor drains, and excavation.

\subsubsection{Vertical Wells}

The use of vertical wells is most common in pump-and-treat technologies for groundwater remediation. However, the low permeability of the aquifer in the area of the groundwater contamination (see Section 2.2.2) precludes the use of such wells for the QROU. Well yields are generally less than $4 \mathrm{~L} / \mathrm{min}(1 \mathrm{gpm})$ for a well $5 \mathrm{~cm}$ (2 in.) in diameter. A significant increase in pumping capacity, as much as a factor of 100 , can be obtained in some cases where the lowpermeability aquifer material would be subjected to fracturing (Miller 1996a). Such a technology uses hydro-, pneumatic-, or blast-fracturing methods applied to bedrock material. Successful application of this method at the quarry area would not be expected because the aquifer material in the contaminated area is primarily alluvium, a material that would deform rather than fracture when subjected to the physical forces applied. Application of fracturing in the bedrock portion of the aquifer (the Decorah Group) would risk the formation of vertical cracks and fissures into the underlying Plattin Limestone layer, which is not heavily contaminated. These cracks and fissures could allow the movement of more contamination into the Plattin Limestone.

\subsubsection{Horizontal Wells}

The use of horizontal wells is a more advanced technology than the use of vertical wells. Horizontal wells could be drilled through the aquifer in an effort to increase the area available for pumping the groundwater. Two methods commonly used to position the wells are directional drilling and trenching. Excavating a trench and partially backfilling it with porous material over a horizontal well pipe can increase the pumping capacity of a well and is similar in concept to fracturing the aquifer around the well intake. Trenching equipment is available that could be used to place horizontal wells at the required depths $(\leq 10 \mathrm{~m}[30 \mathrm{ft}])$ at the quarry area (see Section 2.2.3).

\subsubsection{Interceptor Drains}

A technology employing an interceptor trench drain might be more feasible than horizontal wells because well pump rates would likely be low. A single trench, approximately $10 \mathrm{~m}$ ( $30 \mathrm{ft})$ deep and $610 \mathrm{~m}(2,000 \mathrm{ft})$ long, could be placed perpendicular to the groundwater flow to intercept the contaminated groundwater. The trench could be backfilled with porous material so that the entire 
side of the trench would act as a sink for the groundwater, which would be pumped to a treatment facility. Even with such an arrangement, the limited groundwater flow in the area would be expected to produce a maximum of about $200 \mathrm{~L} / \mathrm{min}$ ( $50 \mathrm{gpm}$ ) under the best conditions (see Appendix B). The advantages of a trench, when properly positioned, are its simplicity and effectiveness - in this case, ensuring that any contaminated water would be intercepted.

\subsubsection{Excavation}

Because of the low permeability of the aquifer, the aquifer material could be excavated for treatment and disposal. Conventional earthmoving equipment (e.g., bulldozers, backhoes, and frontend loaders) could be used in conjunction with hydraulic dredges and pumps. The uncontaminated overlying soil could be stripped off and replaced after removal of the underlying contaminated aquifer material. The cost of excavating the entire area down to bedrock in many places is not warranted.

\subsubsection{Summary}

The screening analysis for removal of groundwater is summarized in Table 2.3. The technology of an interceptor drain has been retained as potentially applicable to a groundwater remedial action at the quarry area. On the basis of implementability, vertical and horizontal wells were rejected from further consideration because of the inability to pump water from the aquifer at an efficient rate. Excavation was rejected from further consideration on the basis of the very high cost, considering the low contaminant concentrations in the aquifer material.

\subsubsection{Ex-Situ Treatment}

Ex-situ treatment consists of technologies that treat the groundwater and any contaminated soil or sludge after their removal from the aquifer (groundwater removal is discussed in Section 2.2.5). The many methods available for treating contaminated groundwater rely on the physical, chemical, or biological properties of the contaminants. 
TABLE 2.3 Summary of Screening Analysis for Groundwater Removal

\begin{tabular}{|c|c|c|c|}
\hline Removal Measure & Effectiveness & Implementability & Cost \\
\hline Vertical wells & $\begin{array}{l}\text { Standard method for removing } \\
\text { groundwater from an underground } \\
\text { aquifer. }\end{array}$ & $\begin{array}{l}\text { Very difficult to implement. The } \\
\text { low permeability of the aquifer } \\
\text { would preclude reasonable pump } \\
\text { rates. }\end{array}$ & $\begin{array}{l}\text { Low to } \\
\text { moderate }\end{array}$ \\
\hline Horizontal wells & $\begin{array}{l}\text { Larger surface area for collecting } \\
\text { groundwater than a conventional } \\
\text { vertical well for increasing pump } \\
\text { rates. }\end{array}$ & $\begin{array}{l}\text { Very difficult to implement. The } \\
\text { low permeability of the aquifer } \\
\text { would preclude reasonable pump } \\
\text { rates. }\end{array}$ & Moderate \\
\hline Interceptor drain & $\begin{array}{l}\text { A trench could be placed just north } \\
\text { of Femme Osage Slough, perpen- } \\
\text { dicular to the groundwater flow, to } \\
\text { intercept all contaminated ground- } \\
\text { water leaving the area. The ground- } \\
\text { water that collected in the trench } \\
\text { could then be pumped out for } \\
\text { treatment. }\end{array}$ & $\begin{array}{l}\text { Could be implemented with } \\
\text { conventional methods and } \\
\text { equipment. }\end{array}$ & $\begin{array}{l}\text { Low to } \\
\text { moderate }\end{array}$ \\
\hline $\begin{array}{l}\text { Excavation/dredging } \\
\text { and pumping }\end{array}$ & $\begin{array}{l}\text { Could effectively remove contami- } \\
\text { nated material in the aquifer. The } \\
\text { remaining contamination in the } \\
\text { aquifer material would be below } \\
\text { appropriate concentration levels. }\end{array}$ & $\begin{array}{l}\text { Could be implemented with } \\
\text { conventional equipment and } \\
\text { procedures. }\end{array}$ & High \\
\hline
\end{tabular}

\subsubsection{Physical Treatment}

Settling or Centrifuge. Settling (sedimentation) tanks for removal of suspended solids constitute one of the first stages of many water treatment plants. Settling tanks allow these nondissolved solids (approximately $10 \mu \mathrm{m}$ in diameter or larger) to settle to the bottom of the tank under the influence of gravity. After an appropriate time period, the clarified water may then be drawn off and sent on to the next phase of treatment. Centrifuges may also be used to remove suspended particles from solution. In addition, settling tanks may be used in conjunction with chemical precipitation treatments.

Filtration. Filtration is another process found in many water treatment plants. Like settling, filtration is used for removing suspended solids. Filters may consist of a single thin membrane (typically a polycarbonate) or a granular medium (typically sand in a filter bed). The driving force is either gravity or a pressure differential such as applied pressure or an induced vacuum. Filtration is relatively simple to operate and maintain, and like settling, filtration is an old and proven technology. Filtration is often used in conjunction with chemical precipitation processes. 
Evaporation. Evaporation is used primarily for reducing the volume of contaminated water or sludge wastes and for concentrating nonvolatile contaminants. Any volatile contaminants must be removed prior to this treatment process. Evaporation of water leaves behind all nondissolved and dissolved solids. The treated waste must then be mechanically removed for further treatment or disposal. Evaporation ponds are often used as retention areas for treated wastewater in between treatment steps. Evaporation is a well-established treatment process.

Reverse Osmosis. Reverse osmosis is commonly used to remove dissolved species from solution. Osmosis is the tendency of a solvent such as water to pass through a semipermeable membrane from the side with a lower solute (dissolved species) concentration to the side with a higher solute concentration in an attempt to equalize concentrations on both sides of the membrane. The membrane is semipermeable in that it permits migration of water but not the dissolved species. This process may be reversed, hence the term reverse osmosis, by applying pressure to the side with a high solute concentration. The dissolved species thus become more concentrated, thereby reducing the volume of contaminated water. Reverse osmosis is very effective at removing almost all dissolved species. This process has an efficiency of approximately 98 to $99 \%$ for removal of dissolved uranium (EPA 1993a).

\subsubsection{Chemical/Physical Treatments}

Coagulation/Flocculation. Coagulation is a chemical treatment process in which chemicals are added to promote particle growth under flocculation, a physical process that increases particle collisions through slow mixing with large blades or paddles. Coagulation/flocculation is often used in conjunction with precipitation processes or as a component in a settling or filtration treatment stage.

Precipitation. Precipitation of inorganic contaminants in water is induced by a chemical reaction that converts a soluble contaminant species to an insoluble form. Removal of the precipitate is then accomplished through sedimentation or filtration. One advantage of precipitation treatments is the relatively low waste volumes produced. Because of the diverse chemical species found in groundwater, selection of the proper chemicals for use generally requires bench and field studies that often include $\mathrm{pH}$ adjustment for optimum results. Precipitation is an effective and well-established treatment for many contaminants and has been a primary treatment for metals in industrial waste waters for years (DOD 1994). Lime softening is one precipitation process that has an efficiency of approximately 85 to $99 \%$ for removal of dissolved uranium (EPA 1993a). 
Ion Exchange. Ion exchange is a process in which ions of interest are exchanged for other ions held on an insoluble exchange material. The exchange material is generally a synthetic organic resin that is stable under a wide range of temperature and $\mathrm{pH}$ conditions. These materials can be tailored to be highly specific toward a given ion. Once a resin becomes saturated with the target ion, the resin can be regenerated using a highly concentrated solution of the relatively harmless, originally bound ion. This solution shifts the equilibrium back to the original state of the resin, leaving a solution concentrated in the target (contaminant) ion. Ion exchange is a well-established treatment for many contaminants, and it has an efficiency of approximately 65 to $99 \%$ for removal of dissolved uranium (EPA 1993a). Ion exchange is one of the most commonly used methods at sites with uranium-contaminated groundwater (DOE 1991).

Liquid-liquid extraction. Liquid-liquid extraction involves the complexation of an inorganic species such as a dissolved uranium ion with an organic compound. The contaminated aqueous solution is then mixed with an organic solvent that is not soluble in water. The complexed species is designed to be more soluble in the organic solvent than water, and, therefore, is preferentially extracted into the organic liquid phase, which is subsequently drawn off from the aqueous phase. The method can be highly selective toward a single contaminant in a complex solution. Liquid-liquid extraction has been used extensively in the nuclear industry for the processing of spent nuclear fuel for the separation of uranium and plutonium (Ivanovich and Harmon 1992). However, the involvement of an organic liquid phase, often a hazardous chemical itself, relegates this method to smaller scale operations where other methods have proven ineffective.

Magnetic Separation. Two different types of magnetic separation processes have recently been investigated for the remediation of contaminated groundwater - the Mag* ${ }^{S e p}{ }^{S M}$ and highgradient magnetic separation (HGMS).

The Mag*Sep ${ }^{S M}$ process injects engineered particles into a liquid waste stream. The particles range in size from 25 to $300 \mu \mathrm{m}$, have a magnetic core, and are coated with a functionalized resin. The resin acts in a manner similar to ion-exchange resins; that is, they adsorb selective target ions. After the particles have been in the contaminated water for an appropriate period of time, they are magnetically removed from solution (DOE 1996). The process is claimed to be more selective than ion exchange and, therefore, produces less waste product. No full-scale commercial applications of this process have been conducted for remediation of uranium in groundwater.

The HGMS process passes the contaminated fluid through a highly magnetized volume containing a magnetic matrix material such as steel wool. A slightly magnetic contaminant species such as uranium becomes attached to the matrix material and is then removed from solution. The process results in very small waste volumes. Application of this technology to water treatment is still in the research phase at Los Alamos National Laboratory. 
Supported Liquid Membranes. A liquid membrane containing a complexing agent for a specific contaminant such as uranium is supported on a hollow fiber membrane through which a liquid waste stream is passed. The complexing agent attaches to its target ion when the ion contacts the liquid membrane. The contaminant ion complex is then selectively passed through the membrane where it comes into contact with a stripping solution. Supported liquid membranes have been studied for over 20 years for a variety of applications and more recently for the removal of uranium, chromium, and technetium from contaminated groundwaters (DOE 1995). The interest in the process is related to its high target specificity, which results in reduced waste volumes. Also, the recovered contaminant, such as uranium, would be in a reasonably pure form for potential reuse. However, no field tests have been reported.

Ultraviolet Oxidation. Ultraviolet (UV) oxidation is a treatment process for organic compounds and is effective in the treatment of nitroaromatic compounds (DOD 1994). Its primary advantage over other methods such as carbon adsorption is its destruction of the contaminant compounds; it is capable of complete mineralization to carbon dioxide, water, and salts. The process involves exposing the contaminated water to strong UV light in the presence of strong chemical oxidizers such as ozone and/or hydrogen peroxide. UV oxidation is an established treatment process and is readily available from commercial vendors.

Granular Activated Carbon. Carbon adsorption is very effective in treating organically contaminated waste waters. Granular activated carbon (GAC) has a high surface area and has been used extensively in treating process waters at munitions plants (EPA 1993a). The process involves the adsorption of organic contaminants on carbon surfaces as the waste water is passed through a GAC filter. Therefore, the contaminants are not destroyed, and the GAC in the filter must be further treated or disposed of. Carbon adsorption is readily available from commercial vendors since it is a well-established technology for treating municipal, industrial, and hazardous wastes.

Incineration. Incineration is not directly applicable to groundwater treatment, but can be used to treat secondary waste products. The incineration of hazardous wastes is an effective technology for destruction of organic contaminants and can also be used for volume reduction of combustible wastes contaminated with inorganic contaminants. Furnace temperatures typically range from 870 to $1,200^{\circ} \mathrm{C}\left(1,400\right.$ to $\left.2,200^{\circ} \mathrm{F}\right)$. Incineration has been used for the destruction of nitroaromatic compounds in contaminated soils (EPA 1993a). The technology is readily available from commercial vendors. 


\subsubsection{Biological/Physical Treatments}

Biosorption/Biotransformation. Biosorption of uranium by microorganisms is currently being studied for use in treating contaminated water. Microorganisms can be fixed in media in a filter bed or injected into solution, thus absorbing the uranium as the water is passed through the filter. Filtration or centrifugation of the biomass would be necessary for processes where the microorganisms were not fixed in a filter media.

Biotransformation involves the oxidation or reduction of metals by microorganisms, which may result in conversion to an insoluble form. The precipitated form may then be removed through filtration or centrifugation. Both biosorption and biotransformation processes are still in the research stage for cleaning contaminated water.

Biodegradation. Bioreactors are used to degrade organic contaminants in water with microorganisms suspended in solution or fixed on an inert support matrix (DOD 1994). To ensure effectiveness, microorganisms must first be identified that are capable of degrading the target contaminants. Biodegradation is a well-developed technology for treating municipal wastewater in which the organic waste content is usually higher and of a different nature than that found at remedial action sites. The primary advantage of biodegradation is the destruction of the target compounds. The use of bioreactors for treating nitroaromatic compounds is only in the developmental stage, but has proven to be effective in lab-scale tests (EPA 1993a).

\subsubsection{Summary}

The screening analysis for ex-situ treatment of groundwater is summarized in Table 2.4. All physical and chemical treatment technologies, except the supported liquid membrane and magnetic separation technologies for uranium, have been retained for possible use in conjunction with groundwater extraction from the contaminated area north of the quarry. Determination of the appropriate technologies would depend on the chemical characteristics of the groundwater at the time of extraction. The biological treatment technologies were not retained for further consideration because they are not fully developed and do not have any significant advantages over the established chemical treatment technologies for ex-situ treatment of groundwater.

\subsubsection{Disposal}

The disposal options could be used to support other groundwater response actions. These options are limited to the disposal of contaminated solids generated as by-products of other response 
TABLE 2.4 Summary of Screening Analysis for Ex-Situ Treatment Measures

\begin{tabular}{|c|c|c|c|}
\hline Ex-Situ Measure & Effectiveness & Implementability & Cost \\
\hline Filtration & $\begin{array}{l}\text { Preliminary step to separate suspended solids from } \\
\text { the extracted groundwater. }\end{array}$ & Would be easy to implement. & Low \\
\hline Coagulation/flocculation & Used to enhance filtration and settling processes. & Would be easy to implement. & Low \\
\hline Setting/centrifuge & $\begin{array}{l}\text { Preliminary step to separate suspended solids from } \\
\text { the extracted groundwater. }\end{array}$ & Would be easy to implement. & Low \\
\hline Evaporation & $\begin{array}{l}\text { Consolidates suspended and dissolved solids by } \\
\text { driving off the water. The resulting contaminated } \\
\text { solid can be sent for disposal. }\end{array}$ & Would be easy to implement. & Low \\
\hline Reverse osmosis & $\begin{array}{l}\text { Potential preliminary step for treatment. Effective } \\
\text { at concentrating dissolved contaminants in solution. }\end{array}$ & $\begin{array}{l}\text { Could be implemented with } \\
\text { existing technology. }\end{array}$ & Moderate \\
\hline Coprecipitation & $\begin{array}{l}\text { Conventional method for extracting uranium from } \\
\text { solution. Dependent on dissolved species. }\end{array}$ & $\begin{array}{l}\text { Could be implemented with } \\
\text { existing technology. }\end{array}$ & Moderate \\
\hline Ion exchange & $\begin{array}{l}\text { Conventional method for extracting uranium and } \\
\text { nitrates from solution. Dependent on dissolved } \\
\text { species. }\end{array}$ & $\begin{array}{l}\text { Could be implemented with } \\
\text { existing technology. }\end{array}$ & Moderate \\
\hline Liquid-liquid extraction & $\begin{array}{l}\text { Conventional method for extracting uranium from } \\
\text { solution. Dependent on dissolved species. }\end{array}$ & $\begin{array}{l}\text { Could be implemented with } \\
\text { existing technology. }\end{array}$ & Moclerate \\
\hline $\begin{array}{l}\text { Supported liquid } \\
\text { membranes }\end{array}$ & $\begin{array}{l}\text { Newer technology for dissolved metal extraction } \\
\text { being investigated for remediation programs. }\end{array}$ & Implementation questionable. & High \\
\hline Magnetic separation & $\begin{array}{l}\text { Newer technology for dissolved metal extraction } \\
\text { being investigated for remediation programs. }\end{array}$ & Implementation questionable. & High \\
\hline Ultraviolet oxidation & $\begin{array}{l}\text { Conventional method for degradation of nitro- } \\
\text { aromatic compounds. }\end{array}$ & $\begin{array}{l}\text { Could be implemented with } \\
\text { existing technology. }\end{array}$ & Moclerate \\
\hline $\begin{array}{l}\text { Granular activated } \\
\text { carbon }\end{array}$ & $\begin{array}{l}\text { Conventional method for extraction of } \\
\text { nitroaromatic compounds from solution. }\end{array}$ & $\begin{array}{l}\text { Could be implemented with } \\
\text { existing technology. }\end{array}$ & Moclerate \\
\hline Biosorption & $\begin{array}{l}\text { Newer technology under development for dissolved } \\
\text { metal extraction being investigated for remediation } \\
\text { programs. }\end{array}$ & Implementation questionable. & High \\
\hline Biodegradation & $\begin{array}{l}\text { Newer technology under development for degrada- } \\
\text { tion of nitroaromatic compounds by micro- } \\
\text { organisms being investigated for remediation } \\
\text { programs. }\end{array}$ & Implementation questionable. & High \\
\hline Incineration & $\begin{array}{l}\text { Supporting measure. Conventional method for } \\
\text { destruction of organic compounds and waste } \\
\text { volume reduction. }\end{array}$ & $\begin{array}{l}\text { Could be implemented with } \\
\text { existing technology. }\end{array}$ & $\begin{array}{l}\text { Moderate } \\
\text { to high }\end{array}$ \\
\hline
\end{tabular}


actions. All contaminated waste resulting from groundwater remediation would be placed in the planned on-site disposal cell or at an off-site facility after the cell was closed. Any treated process water or groundwater would be discharged to the Missouri River through the existing water discharge pipeline at the quarry water treatment plant (QWTP). Uncontaminated solid process waste could be disposed of off-site at a commercial facility, as appropriate.

\subsection{POTENTIALLY APPLICABLE TECHNOLOGIES}

Potentially applicable technologies for groundwater remediation are summarized in Table 2.5. This summary is based on the screening analysis presented in Section 2.2. The technologies that have been retained through this analysis were used to develop preliminary remedial action alternatives for the site. These alternatives are identified in Chapter 3. 
TABLE 2.5 Screening of Potentially Applicable Technologies for Groundwater Remediation

\begin{tabular}{|c|c|c|c|}
\hline $\begin{array}{l}\text { General Response } \\
\text { Action }\end{array}$ & Technology Type & $\begin{array}{l}\text { Evaluation } \\
\text { Result }\end{array}$ & Comments \\
\hline \multirow[t]{2}{*}{ Institutional controls } & $\begin{array}{l}\text { Groundwater access } \\
\text { restrictions }\end{array}$ & Retained & $\begin{array}{l}\text { Could effectively limit access to areas with contaminated } \\
\text { groundwater and could be used to support other response } \\
\text { actions. }\end{array}$ \\
\hline & $\begin{array}{l}\text { Ownership and } \\
\text { land-use or deed } \\
\text { restrictions }\end{array}$ & Retained & $\begin{array}{l}\text { Could minimize exposures to site contaminants by limiting } \\
\text { use of contaminated groundwater areas and could be used to } \\
\text { support other actions. }\end{array}$ \\
\hline Monitoring & Vertical wells & Retained & $\begin{array}{l}\text { Could provide data useful for minimizing exposures and } \\
\text { could be used to support other response actions. }\end{array}$ \\
\hline \multirow[t]{3}{*}{ In-situ containment } & Physical barrier & Retained & Could effectively limit migration of contaminant materials. \\
\hline & Hydraulic containment & Rejected & $\begin{array}{l}\text { Could not effectively control water flow because of the } \\
\text { aquifer's sloping base and the low and contrasting } \\
\text { permeabilities found within the aquifer. }\end{array}$ \\
\hline & Immobilization & Rejected & $\begin{array}{l}\text { Could not inject the required materials into the aquifer } \\
\text { because of the aquifer's low permeability. Uniform delivery } \\
\text { of the materials is also questionable. }\end{array}$ \\
\hline \multirow[t]{6}{*}{ In-situ treatment } & Natural processes & Retained & $\begin{array}{l}\text { Could reduce contaminant concentrations given sufficient } \\
\text { time and could be used to support other response actions. }\end{array}$ \\
\hline & Bioremediation & Rejected & $\begin{array}{l}\text { Could not inject the required materials into the aquifer } \\
\text { because of the aquifer's low permeability. Uniform delivery } \\
\text { of the materials is also questionable. }\end{array}$ \\
\hline & Electrokinetics & Rejected & $\begin{array}{l}\text { Contaminated area is too large for this technology to be } \\
\text { feasible, and its effectiveness in removing uranium contami- } \\
\text { nation is still in the demonstration phase in the United } \\
\text { States. }\end{array}$ \\
\hline & Uranium mining & Rejected & $\begin{array}{l}\text { Could not inject the required materials into the aquifer } \\
\text { because of the aquifer's low permeability. Uniform delivery } \\
\text { of the materials is also questionable. Mobilized uranium } \\
\text { might be difficult to control. }\end{array}$ \\
\hline & Reactive wall & Retained & $\begin{array}{l}\text { Permeable wall could be effective in removing contaminants } \\
\text { from groundwater as the groundwater passed through the } \\
\text { wall. }\end{array}$ \\
\hline & Phytoremediation & Rejected & $\begin{array}{l}\text { Ineffective at remediating contamination that is more than } \\
\text { about } 3 \mathrm{~m}(10 \mathrm{ft}) \text { deep. }\end{array}$ \\
\hline \multirow[t]{3}{*}{ Removal } & Vertical wells & Rejected & $\begin{array}{l}\text { Ineffective for pumping groundwater because of the } \\
\text { aquifer's low permeability. }\end{array}$ \\
\hline & Horizontal wells & Rejected & $\begin{array}{l}\text { Ineffective for pumping groundwater because of the } \\
\text { aquifer's low permeability. }\end{array}$ \\
\hline & Interceptor drain & Retained & $\begin{array}{l}\text { Could be effective in capturing the groundwater as it left the } \\
\text { contaminated area. }\end{array}$ \\
\hline
\end{tabular}


TABLE 2.5 (Cont.)

\begin{tabular}{|c|c|c|c|}
\hline $\begin{array}{l}\text { General Response } \\
\text { Action }\end{array}$ & Technology Type & $\begin{array}{l}\text { Evaluation } \\
\text { Result }\end{array}$ & Comments \\
\hline Removal (Cont.) & $\begin{array}{l}\text { Excavating/dredging and } \\
\text { pumping }\end{array}$ & Rejected & $\begin{array}{l}\text { Interim actions have already excavated material in vicinity } \\
\text { properties exceeding appropriate levels. The remaining } \\
\text { contaminant concentrations in the aquifer soil material are } \\
\text { below site-derived cleanup levels. }\end{array}$ \\
\hline \multirow[t]{15}{*}{ Ex-situ treatment } & Filtration & Retained & $\begin{array}{l}\text { Effective in removing suspended solids from solutions. } \\
\text { Could be used to support other response actions. }\end{array}$ \\
\hline & Coagulation/Flocculation & Retained & Effective in enhancing filtration and settling processes. \\
\hline & Settling/centrifuge & Retained & $\begin{array}{l}\text { Effective in removing suspended solids from solution. Could } \\
\text { be used to support other response actions. }\end{array}$ \\
\hline & Evaporation & Retained & $\begin{array}{l}\text { Effective in removing suspended and dissolved solids from } \\
\text { solution. Could be used to support other response actions. }\end{array}$ \\
\hline & Reverse osmosis & Retained & $\begin{array}{l}\text { Effective in concentrating contaminants in solution. Could } \\
\text { be used to support other response actions. }\end{array}$ \\
\hline & Coprecipitation & Retained & $\begin{array}{l}\text { Effective conventional method for removing uranium from } \\
\text { solution. }\end{array}$ \\
\hline & Ion exchange & Retained & $\begin{array}{l}\text { Effective conventional method for removing uranium from } \\
\text { solution. }\end{array}$ \\
\hline & Liquid-liquid extraction & Retained & $\begin{array}{l}\text { Effective conventional method for removing uranium from } \\
\text { solution. }\end{array}$ \\
\hline & $\begin{array}{l}\text { Supported liquid } \\
\text { membranes }\end{array}$ & Rejected & $\begin{array}{l}\text { Method under development for removing metals from } \\
\text { solution. }\end{array}$ \\
\hline & Magnetic separation & Rejected & $\begin{array}{l}\text { Method under development for removing metals from } \\
\text { solution. }\end{array}$ \\
\hline & Ultraviolet oxidation & Retained & $\begin{array}{l}\text { Effective conventional method for degrading nitroaromatics } \\
\text { from solution. }\end{array}$ \\
\hline & Granular activated carbon & Retained & $\begin{array}{l}\text { Effective conventional method for removing nitroaromatics } \\
\text { from solution. }\end{array}$ \\
\hline & Biosorption & Rejected & $\begin{array}{l}\text { Method under development for removing metals from } \\
\text { solution. }\end{array}$ \\
\hline & Biodegradation & Rejected & $\begin{array}{l}\text { Method under development for degrading organics in } \\
\text { solution. }\end{array}$ \\
\hline & Incineration & Retained & $\begin{array}{l}\text { Effective conventional method for degrading organic } \\
\text { compounds and reducing waste volumes. Could be used to } \\
\text { support other response actions. }\end{array}$ \\
\hline
\end{tabular}

Disposal

On-site disposal cell

Off-site facility
Retained Effective for disposing of waste generated by other response actions.

Retained Might be required if quantity or type of waste could not be accommodated by the on-site disposal cell or if the cell was closed. 


\section{DEVELOPMENT AND SCREENING OF PRELIMINARY ALTERNATIVES}

The purpose of a feasibility study and the overall remedy selection process is to identify, evaluate, and select appropriate remedial actions that eliminate, reduce, or control risks to human health and the environment. This chapter discusses the development and screening of preliminary alternatives assembled from combinations of technologies and associated process options that were retained following the screening and evaluation procedures described in Chapter 2.

\subsection{CRITERIA FOR DEVELOPING ALTERNATIVES}

The criteria for developing action alternatives are provided in guidance from the EPA (1988a) and the NCP (EPA 1990a). These criteria are used to develop alternatives that protect human health and the environment by controlling risks posed through each exposure pathway at a site. The number and types of alternatives to be analyzed are site specific and take into account the scope, characteristics, and complexity of the problem being addressed. The following types of alternatives were developed for the QROU in accordance with EPA guidance:

- Alternatives that involve treatment as a principal component to reduce the toxicity, mobility, or volume of the hazardous substances, pollutants, or contaminants remaining at the site. As appropriate, this range of treatment alternatives should include an alternative that removes or destroys hazardous substances, pollutants, or contaminants to the maximum extent feasible, thereby eliminating or minimizing to the degree possible, the need for longterm management.

- Containment alternatives that involve little or no treatment but provide protection of human health and the environment by preventing or controlling exposure to hazardous substances, pollutants, or contaminants. These alternatives might include engineering controls and, as necessary, institutional controls to protect human health and the environment and to ensure continued effectiveness of the response action.

- A no action alternative, which might involve no further action if some removal or remedial action had already occurred at the site, is included as a baseline for comparison with other alternatives.

The general response actions for groundwater identified in Chapter 2 are (1) institutional controls, excluding monitoring; (2) monitoring; (3) containment; (4) in-situ treatment; and (5) extraction and treatment. Institutional controls include access and legal restrictions. Groundwater 
monitoring for the QROU would include the existing monitoring well network, as well as any additional wells to be constructed as part of an alternative action. Containment actions could include interception of groundwater, installation of horizontal and vertical barriers, and containment by pumping. Treatment actions could include physicochemical treatment, biological treatment, thermal treatment, electrical treatment (e.g., in-situ electrokinetics), and in-situ treatment.

\subsection{IDENTIFICATION OF PRELIMINARY ALTERNATIVES}

Preliminary alternatives were assembled from combinations of technologies and associated management strategies (e.g., institutional controls and well restrictions) that were retained following, the screening and evaluation process described in Chapter 2. Potential action alternatives were: screened to eliminate those alternatives determined too difficult to implement on the basis of unproven technologies, those determined not sufficient to remediate the site within a reasonable time period, or those determined to have limited application for the specific contaminant or site conditions: (EPA 1988a). The technologies and management strategies that were not eliminated were: incorporated into the following preliminary alternatives:

- Alternative 1: No Action;

- Alternative 2: Monitoring with No Active Remediation;

- Alternative 3: Groundwater Removal with On-Site Treatment;

- Alternative 4: Containment;

- Alternative 5: In-Situ Treatment Using Permeable Barriers; and

- Alternative 6: Groundwater Removal at Selected Areas, with On-Site Treatment.

The alternatives range from no action, in which no further action would be taken at the site, to in-situ treatment of the groundwater, which would reduce future migration of the contamination toward the St. Charles County well field.

\subsubsection{Factors Common to Preliminary Action Alternatives}

The approaches for implementing these six preliminary alternatives contain a number of similar activities. For example, it was assumed that monitoring would occur during the cleanup 
period under each of the preliminary action alternatives. Monitoring would be continued, as needed, for those alternatives not involving active removal of contaminants from the groundwater.

Current restoration plans for the quarry include backfilling with soil. For this FS, it was assumed that this activity would have been implemented to complement any remedial action performed for quarry groundwater.

Each alternative (other than no action) would require various support operations before implementation. These activities would include the design and construction of staging/storage areas for wastes, procurement of appropriate equipment, and development of contingency plans and operational controls to minimize contaminant releases (see Section 3.2.2).

\subsubsection{Factors Specific to Each Preliminary Alternative}

\subsubsection{Alternative 1: No Action}

The No Action Alternative (Alternative 1) is intended to provide a baseline for comparison with the other alternatives evaluated. Under Alternative 1, no further action would be taken at the site, and any currently ongoing maintenance and monitoring would be discontinued. This alternative would not provide for any active or passive institutional controls to reduce the potential for exposure to contaminants currently in the quarry groundwater. Alternative 1 is by definition a zero-cost, zeroprotection alternative in that it provides no added protection to any receptor in the form of engineering or institutional controls.

\subsubsection{Alternative 2: Monitoring with No Active Remediation}

Alternative 2 would not involve groundwater extraction, in-situ or ex-situ treatment, or containment actions. It would rely upon the groundwater's natural ability to lower contaminant concentrations through physical, chemical (including reduction and precipitation), and biological processes until appropriately low levels were achieved. These processes include adsorption to soil particles, biodegradation (for nitroaromatic compounds), and dilution and dispersion in groundwater. (Changes in $\mathrm{pH}$ and $\mathrm{Eh}$ in the groundwater north of the Femme Osage Slough have occurred during flood conditions; in this case, however, contaminant concentrations are greatly reduced because of the introduction of uncontaminated floodwater.)

At the quarry area, the migration of residual contamination from the quarry proper to areas south of the slough is generally prevented by reduction and precipitation, dilution, and sorption (DOE 1998b), although slightly greater than background values have been measured at RMW-2. The 
contaminants in the groundwater north of the slough appear to be retarded. Data from the 26 groundwater monitoring wells located north and south of Femme Osage Slough (DOE 1998b) show that groundwater between the quarry and the slough is contaminated with chemical and radioactive constituents from waste that was previously disposed of in the quarry. It has been postulated that uranium precipitation in solid phases occurs in a reduction front along the slough and acts as a geochemical barrier to contaminant migration south of the slough toward the alluvial well field that supplies drinking water (DOE 1998b). The geochemistry of the groundwater north of the slough ( $\mathrm{pH}$ of about 7 and $\mathrm{Eh}<0$ ) supports the precipitation of uranium in the forms of $\mathrm{USiO}_{4}$ (coffinite) and $\mathrm{UO}_{2}$ (uraninite). Fate and transport modeling results appear to indicate that natural processes will likely maintain contaminant concentrations below the metric of $30 \mathrm{pCi} / \mathrm{L}$ in the vicinity of the public drinking wells, primarily because of dilution and dispersion. Although inherent uncertainties are associated with these observations, they suggest that active remediation might nor: be necessary.

Further, certain conditions at the quarry area appear to be consistent with those identified by the EPA (1988a) as conditions that would be suitable for taking natural attenuation as an approach. to ultimately achieving contamination reduction. Conditions at the quarry area that would apply include the following:

1. Quarry groundwater is not available in sufficient quantity at any depth to meet the needs of an average household.

2. Precipitation of uranium from solution as insoluble compounds could be occurring in the fine-grained soils adjacent to the slough within the alluvial aquifer. Uranium is a low mobility contaminant north of the slough, because of the low groundwater flow rates, the sorptive capacity of the aquifer material, and the potential for precipitation in the redox zone.

3. Uranium concentrations are less than $1,000 \mathrm{pCi} / \mathrm{L}$ in the majority of the plume. In addition, there have been only six wells where one or more nitroaromatic compounds have been detected at concentrations over $1 \mu \mathrm{g} / \mathrm{L}$ over the last 10 years of monitoring. One well had a detected 1,3-dinitrobenzene concentration greater than $1.0 \mu \mathrm{g} / \mathrm{L}$ prior to bulk waste removal; no nitroaromatic compounds have been detected in more recent data (circa 1996 and 1997). For 2,4-dinitrotoluene, maximum concentrations in three wells (MW-1005, MW-1006, and MW-1027) ranged from 0.15 to $2.5 \mu \mathrm{g} / \mathrm{L}$, marginally above the standard for removal of $0.11 \mu \mathrm{g} / \mathrm{L}$.

4. Exposure to quarry groundwater is considered to be unlikely on the basis of current and expected future land use (DOE 1998b). 
5. Groundwater that is used as a drinking water supply in the area is primarily taken from the deep productive aquifer of the Ordovician/Cambrian bedrock system near the chemical plant area and from the alluvial aquifer near the Missouri River. The low yield determined in the quarry area is not expected to support any sustained use of the shallow groundwater (DOE 1998b).

The activities associated with Alternative 2 would involve continued monitoring of groundwater and air, along with well maintenance. Groundwater would be routinely sampled and analyzed to monitor contaminant migration and degradation (in the case of nitroaromatics) to ensure that potential drinking water supplies were continually protected. The direction and rate of movement of the contaminant plume (defined in this chapter as the measurable discharge of a contaminant from a given point of origin [DOE 1991]) would be tracked as a function of time. For this alternative, groundwater monitoring would continue for a period of time specified in the ROD.

Groundwater monitoring would be conducted using the existing well network, as appropriate. The current network might be expanded or reduced accordingly to optimize monitoring activities. However, as an upper-bound evaluation, additional monitoring wells were assumed to be installed and sampled to evaluate the protectiveness of this alternative. For conservatism, the evaluation of Alternative 2 was based on the assumption that the construction and operation of additional wells would be equivalent to approximately $15 \%$ of the number of existing wells.

Because contamination would remain in the groundwater at concentrations above levels that allow for unlimited use and unrestricted exposure, reviews would be conducted at least every five years after the remedy was completed to ensure that it continued to provide adequate protection of human health and the environment. Contingency measures would be considered if future data were to indicate that unacceptable exposure concentrations would appear at the St. Charles County well field. These contingency measures are identified in the Well Field Contingency Plan (DOE 1998c).

It is expected that the concentration of contaminants in the area of the quarry will continue to decrease with time due to removal of the original source of contamination from the quarry and to dilution from infiltration of rainwater and runoff and from sporadic local flooding. A time frame of about 100 to 1,000 years would be expected for the contaminant concentrations to decrease below the metric of $30 \mathrm{pCi} / \mathrm{L}$ as a result of the natural processes that are expected to occur. This estimate is based on the fact that source-control measures to prevent further releases of contaminants to groundwater have been accomplished through bulk waste excavation at the quarry and removal of contaminated soil from Vicinity Property 9. It is also based on the fact that significant migration of uranium contamination south of Femme Osage Slough has not been detected at the St. Charles County well field over the last 40 years. 


\subsubsection{Alternative 3: Groundwater Removal with On-Site Treatment}

Alternative 3 would involve extraction and treatment of the quarry groundwater to achieve a uranium concentration of $30 \mathrm{pCi} / \mathrm{L}$. Quarry area groundwater exceeding this concentration would be removed by use of interceptor trenches, pumped to and treated at either the existing QWTP or a. similar facility, and discharged through a permitted discharge point. Reinjection of the treated groundwater into the aquifer was not considered feasible because of the low permeability of the formation. (The maximum extraction rate from a conventional vertical well is about $0.06 \mathrm{~L} / \mathrm{s}$ [1 gpm] [DOE 1998b].)

The conceptual design of the groundwater removal system is based on extraction using interceptor trenches. This system would involve constructing trenches and installing perforated drainpipe and a bed of crushed stone to collect and convey groundwater flow to a storage tank or sump for treatment. One advantage of interceptor trenches is that they can collect water from a. large subsurface cross section and, thus, increase the rate of groundwater extraction. For this analysis, it

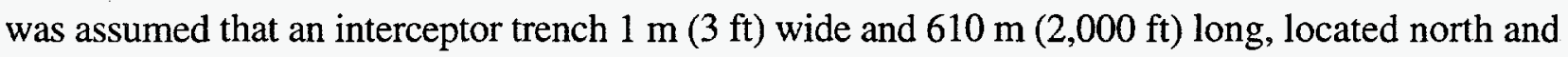
east of the Femme Osage Slough, would be required to achieve a reasonable extraction rate (about 2 to $3 \mathrm{~L} / \mathrm{s}$ [ 30 to $50 \mathrm{gpm}$ ) and to contain further spread of contaminants to the slough. (The hypothetical location of the groundwater removal system is shown in Figure 3.1.) On the basis of cross-sectional data showing the depth to bedrock as a function of distance from the slough

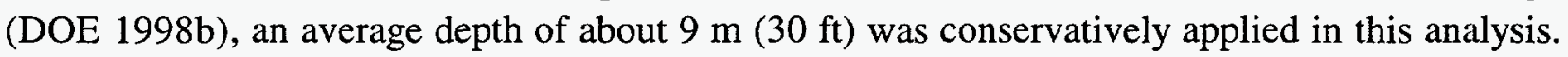
Additional investigation of aquifer characteristics (e.g., bulk soil density, porosity, and partitioning coefficient $\left[\mathrm{K}_{\mathrm{d}}\right]$ at various locations along the slough) would be necessary for detailed evaluation of the placement of the interceptor trench and estimation of groundwater extraction rates. The actual location, size, capacity, and depth of the interceptor trench would be determined during the remedial design phase and would take into account hydrogeologic characteristics (permeability, thickness of the aquifer, and depth of the affected groundwater) and delineation of the contaminant plume.

By applying the range in values for hydrologic variables (e.g., hydraulic conductivity and hydraulic gradient) given in DOE (1998b), the maximum possible extraction rate for an interceptor trench with a length of $610 \mathrm{~m}(2,000 \mathrm{ft})$ was estimated to range from approximately 2 to $3 \mathrm{~L} / \mathrm{s}$ (30 to $50 \mathrm{gpm}$ ) (see Appendix B). Alternative 3 was based on the assumption of an upper extraction rate of approximately $3 \mathrm{~L} / \mathrm{s}(50 \mathrm{gpm})$, which is somewhat less than the nominal treatment capacity of $5 \mathrm{~L} / \mathrm{s}(80 \mathrm{gpm})$ for the QWTP. The maximum uranium concentration of about $4,200 \mathrm{pCi} / \mathrm{L}$ detected during recent groundwater monitoring (DOE 1998b) is less than the maximum allowable concentration of $36,000 \mathrm{pCi} / \mathrm{L}$ for treatment at the QWTP (Valett 1997). 


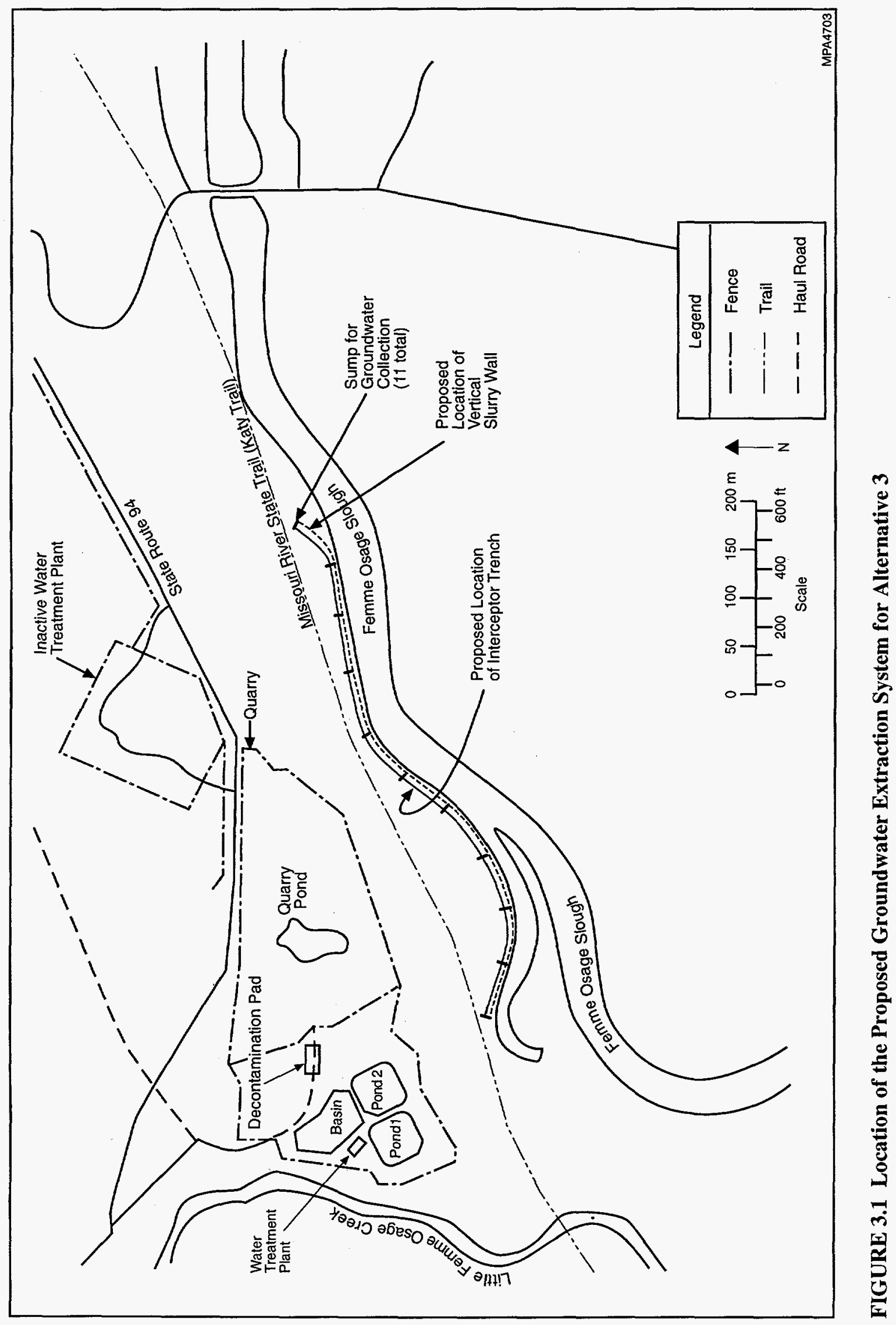


The proximity of Femme Osage Slough requires additional design and operational. considerations for the interceptor trench. Because groundwater pumping would not appreciably draw down the slough level, the slough could serve as a near-infinite source of unwanted water flowing: to the groundwater extraction system. For effective recovery by the interceptor trench system, a. restrictive subsurface structure, such as a containment wall, would be necessary. Standard industrial practice in similar circumstances is to key in a slurry wall into the bedrock to minimize interaction between upgradient groundwater and the groundwater extraction system (see DOE 1993a, 1994a). (A high-density polyethylene [HDPE] liner on the outside wall of the interceptor trench rather than. a slurry wall would not provide adequate strength to maintain structural integrity for adequate: containment.) A slurry wall $610 \mathrm{~m}(2,000 \mathrm{ft})$ long would be constructed near the slough (between. the slough and the interceptor trench) to reduce the inflow to the trench of slough water and groundwater from outside the remediation area.

An area of approximately 1.6 ha (4 acres) would initially be cleared of vegetation to contain the slurry wall and interceptor trench. The slurry wall would then be constructed (see details in Section 3.2.2.4), and a $1-\mathrm{m}$ (3-ft) wide trench would be dug for the interceptor trench. Mechanical excavation involving standard construction methods and earthmoving equipment such as backhoes would be used to remove the soil that is not in contact with groundwater. Mechanical dredging with a clamshell or dragline might be used to remove subsurface media in contact with groundwater, depending upon the groundwater flow rate. (For costing purposes, this analysis assumed excavation using a Caterpillar 235 backhoe with an extension boom and a bucket capacity of approximately $1.9 \mathrm{~m}^{3}\left[2.5 \mathrm{yd}^{3}\right]$; continuous structural excavation using equipment such as a Cleveland JS-36 trencher was determined to be much more costly, on the basis of a comparison of unit costs given in Richardson Engineering Services [1993].) Sidewall protection during excavation would be provided by trench boxes. Access to the excavation areas would be restricted during remedial operations. Actual requirements for these controls would be defined during remedial design, when the detailed sequencing and implementation plans were prepared.

After construction of the interceptor trench, a geotextile fabric would be placed in the bottom of the trench, with enough material to completely cover the gravel layer, and a perforated pipe would be laid on top of the geotextile fabric at the bottom of the trench. The fabric would prevent the perforated collection pipe from filling with solids, such as silt and sand, and clogging. The remaining area within the trench would be filled with crushed stone to ensure that groundwater would be drawn to the collection pipe. Eleven sumps would be placed along the length of the interceptor trench to collect and remove the groundwater. (The total number of sumps was calculated using the methodology provided in the French Drain System for Site Remediation [Naval Energy and Environmental Support Activity 1991], taking into account the hydraulic conductivity and hydraulic gradient of the aquifer and the gravel, as well as the proposed dimensions of the interceptor trench. An interceptor trench system with a single sump using gravity to drain the entire trench length was considered but was determined to be less desirable because this would involve excavation into

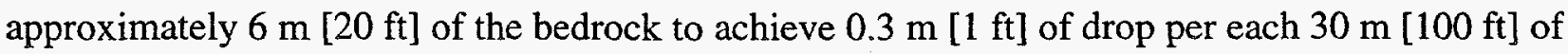


horizontal run for drainage purposes.) This analysis assumed a passive system (i.e., without groundwater gradient control); groundwater pumps would be included for the purpose of evacuating the sumps.

A cap of clay-rich soil would then be placed on the backfill media to form a layer over the contaminated groundwater to limit infiltration of precipitation and to provide weather protection. The cap and backfill would be compacted with a vibrating plate to reduce settling. The excavated areas would be regraded and revegetated. A typical interceptor trench system is illustrated in Figure 3.2.

About $13,000 \mathrm{~m}^{3}\left(17,000 \mathrm{yd}^{3}\right)$ of material would be excavated in the development of the trench and slurry wall systems. This analysis was based on the assumption that the excavated solids would be brought to the chemical plant area at the Weldon Spring site for either direct placement in the on-site engineered disposal facility or temporary stockpiling until placement could take place (Valett 1997).

The air would be monitored during remedial activities so that appropriate mitigative measures could be taken if any airborne contamination was detected. Long-term air monitoring would be implemented following completion of construction to ensure detection of potential airborne releases of contaminants due to system failure of the interceptor trench.

The extracted groundwater would be contained in an aboveground tank before being pumped to a treatment facility. An aboveground tank would be included for groundwater collection to allow potential treatment near the interceptor trench. Use of the QWTP for treatment of the extracted groundwater was assumed for Alternative 3. The treatment capabilities of the QWTP include sedimentation, filtration, chemical treatment, and ion exchange. The nominal treatment capacity is $5 \mathrm{~L} / \mathrm{s}(80 \mathrm{gpm})$, which is greater than the maximum possible extraction rate of $3 \mathrm{~L} / \mathrm{s}$ $(50 \mathrm{gpm})$ assumed for this alternative. It was assumed that if the QWTP were not available, a facility with similar capabilities would be constructed.

A double-wall polyvinyl chloride (PVC) pipeline would be constructed to transfer the water from the interceptor trench storage tank to the QWTP. Groundwater would be pumped from the aboveground tank to the existing equalization basin at the QWTP. The basin serves as a reservoir to provide consistent flow and uniform contaminant concentrations at the QWTP. In the QWTP, water would be subjected to a series of treatment processes to remove uranium, nitrates, and other chemical contaminants (Figure 3.3). The QWTP would be operated on a batch mode and would go into operation whenever the equalization basin contained sufficient water to make operation of the water treatment process feasible.

The treated water from the QWTP would be stored in two existing effluent ponds, each with a capacity of 3.8 million $\mathrm{L}$ ( 1 million gal). The treated water would be tested to verify that the treatments had reduced contaminant concentrations to permissible levels and to confirm compliance 

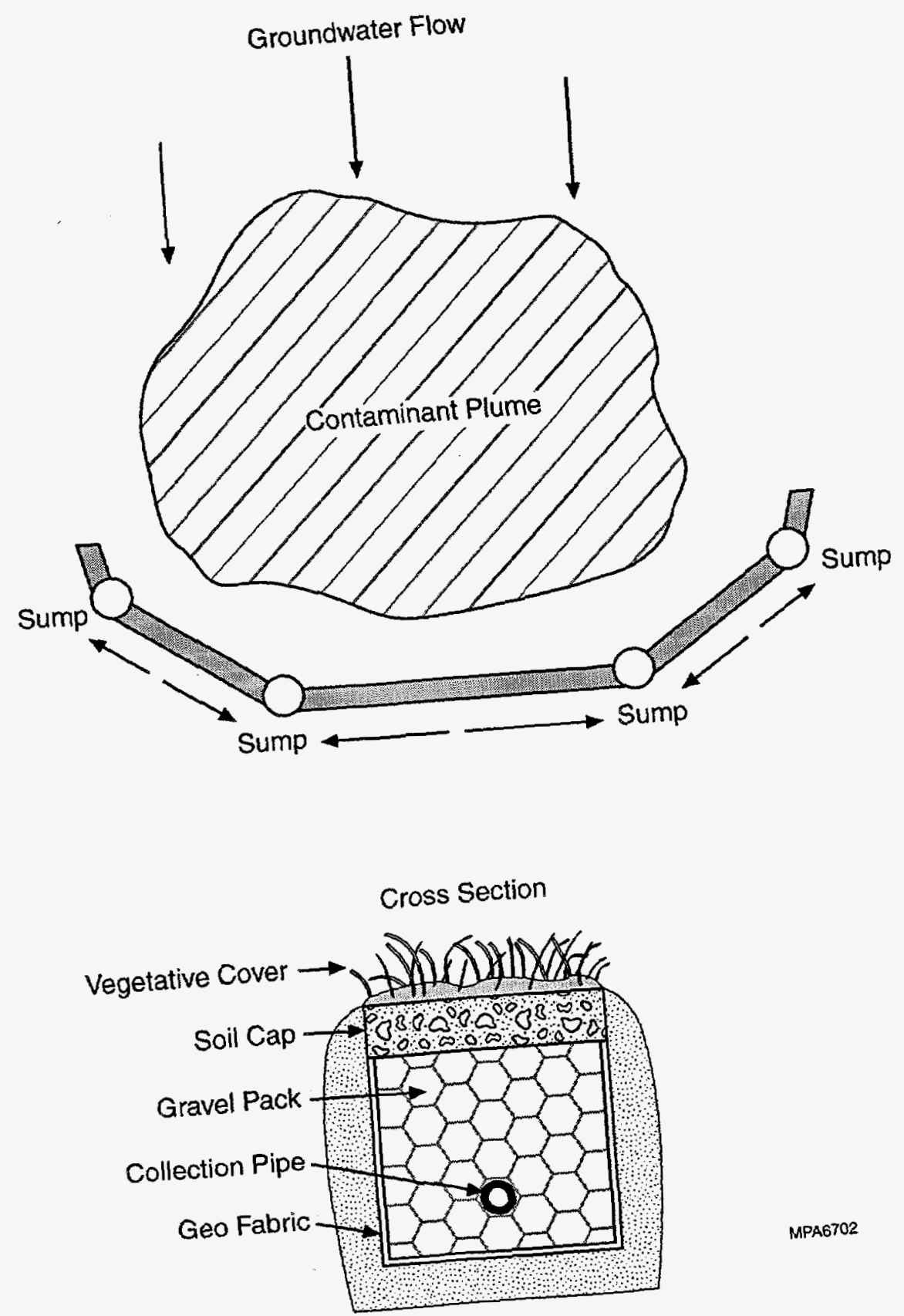

MPA6702

FIGURE 3.2 Schematic of Typical Interceptor Trench System 


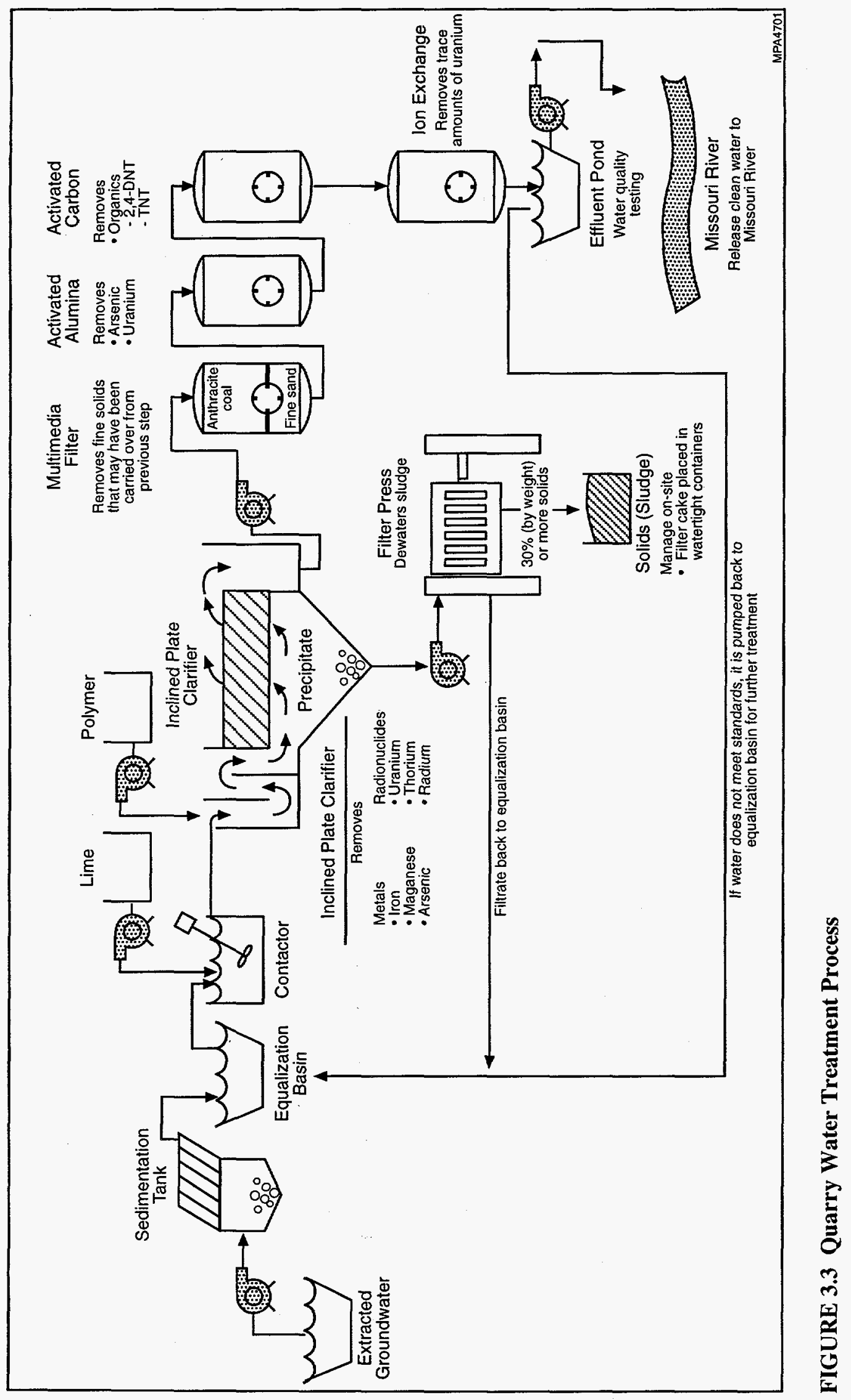


with the requirements of the National Pollutant Discharge Elimination System (NPDES) permit. Treated water meeting the requirements of this permit would be discharged into the Missouri River.

Sludge generated by the water treatment process is currently placed into $3-\mathrm{m}^{3}\left(4-\mathrm{yd}^{3}\right)$ boxes and transported to the temporary storage area at the chemical plant area. The sludge is placed withir. a bermed area constructed on top of the fine-grained soil pile at the temporary storage area and allowed to dewater. Eventually the sludge is mixed within the fine-grained soil matrix of the soil pile: (Valett 1997). This mixture will be disposed of in the on-site engineered disposal facility at the chemical plant area, when it becomes available. Any dewatered sludge generated following closure: of the on-site disposal facility would be packaged for off-site shipment and disposal. The dewatered sludge would be shipped by truck to the off-site licensed disposal facility. Assuming packaging in standard 55-gal drums and truck transport, on average, only one off-site shipment of wastewater sludge to a licensed disposal facility would be required annually.

The maximum radioactivity of the dewatered sludge resulting from groundwater treatment: is estimated to be about $200 \mathrm{pCi} / \mathrm{g}$ of uranium, which is considerably less than the maximum average: concentration of $18,000 \mathrm{pCi} / \mathrm{g}$ of uranium allowed in waste sent to the Envirocare facility in Utah. The maximum value of $200 \mathrm{pCi} / \mathrm{g}$ of uranium was derived on the basis of an assumed concentration. of 3,000 pCi/L of uranium during groundwater monitoring (DOE 1998b) and an assumed value of $1.5 \mathrm{~g}$ of sludge per $100 \mathrm{~g}$ of wastewater (Shropshire et al. 1995). The actual amount of dewatered. sludge would depend on the entrainment of fine silts/sands from the alluvial aquifer into the collection pipe within the interceptor trench.

Stabilization of the dewatered sludge with cement might be necessary to satisfy the waste acceptance criteria of an off-site disposal facility. Treatability studies might be required before the remedial design to determine the most appropriate approach for managing the sludge.

Environmental monitoring would be continued to the extent necessary to ensure long-term performance of the remedy. The period of extraction and treatment for Alternative 3 is conservatively predicted to be at least 200 years (see Appendix B) and would be governed by the natural groundwater flow within the alluvial aquifer and the contaminant concentrations.

\subsubsection{Alternative 4: Containment}

Under Alternative 4, the subsurface contamination would be isolated by installation of lateral barriers that would serve to contain the contaminated groundwater near the quarry area and prevent it from migrating to the production wells, thereby reducing the associated potential for exposure. (The proposed location of the slurry wall system is similar to that shown in Figure 3.1 for the interceptor trench concept.) Engineering controls such as containment are generally used for materials that pose a relatively low long-term threat or in cases where treatment is impracticable. 
This alternative would be developed in conjunction with capping in the quarry area to provide greater effectiveness and reliability. Installation of horizontal barriers to isolate the contaminated shallow aquifer from the deep bedrock aquifer is, however, considered unnecessary. The possibility of contamination migrating to the deep bedrock aquifer is considered extremely remote because of the thick sequence of intervening confining layers and the strong upward hydraulic gradient present within the deep bedrock aquifer (DOE 1994b).

Alternative 4 would involve the use of a vertical slurry wall containing bentonite for containment of the groundwater. A slurry wall is a vertical trench that is excavated under a slurry and backfilled with a material that forms a low-permeability barrier. The slurry, which is usually a mixture of bentonite and water, hydraulically shores the trench to prevent collapse. In addition, the slurry forms a filter cake on the trench walls to prevent high fluid losses into the surrounding ground. Slurry walls are typically differentiated by the materials used to backfill the trench. The soil-bentonite slurry wall, which consists of a backfill mixture of bentonite slurry and soil, is the most common type. (Soil-bentonite slurry walls are best suited to level terrain, such as that present adjacent to the slough; thus, they were considered more appropriate for the QROU because both the slurry and backfill would flow under stress. Cement-bentonite slurry walls were also considered but are not as effective as a bentonite slurry wall and are more appropriate for steeply sloping terrain.) One advantage of a bentonite-based mixture is that the vertical slurry wall may absorb metals such as uranium in groundwater passing through the wall (Marks et al. 1994). Further studies (e.g., treatability studies) would be necessary to determine the degree of uranium capture required (if any).

An area of approximately 0.8 ha ( 2 acres) would initially be cleared of vegetation to contain the slurry wall, and a dike would be constructed as a mixing basin for the slurry (a mixture of soil, bentonite, and/or water, depending on the moisture content of the soil). A narrow trench (1-m [3-ft] wide) would then be excavated, typically by backhoe or dredging. The slurry would be introduced immediately after the trench was opened and before the water table was reached. As excavation continued, more slurry would be added to keep slurry in the trench at all times. Backfilling normally would begin once a sufficient length of trench had been excavated. Backfill would be carefully mixed to the proper consistency and then placed in the trench using a bulldozer. The completed slurry wall would typically be covered with a compacted soil cap.

Because hydraulic head differences would develop in groundwater on either side of the barrier, the vertical barrier would have to extend from the surface downward to below the upper

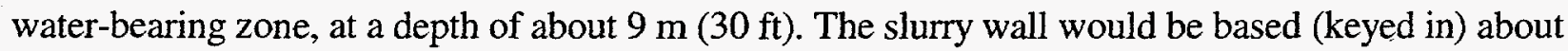
0.6 to $0.9 \mathrm{~m} \mathrm{(} 2$ to $3 \mathrm{ft}$ ) into the bedrock to provide an effective foundation with minimum leakage potential (Marks et al. 1994). It is estimated that a slurry wall about $610 \mathrm{~m}(2,000 \mathrm{ft})$ long would be needed. After the wall had been constructed, the upper $0.15 \mathrm{~m}(0.5 \mathrm{ft})$ of the trench would be backfilled and compacted. The backfill would be material with low hydraulic conductivity, which would act as a cap to restrict vertical spread of contamination and protect the slurry wall from drying 
and cracking. Once the system was in place, the mixing basin would be demolished and the working, surface regraded. Excavated material would be placed over the cap layer, and the excavated areas: would be regraded and revegetated. A schematic of a typical keyed-in slurry wall system is provided in Figure 3.4.

The permeability of a slurry wall installed to control contaminated groundwater is largely dependent on the backfill material and is generally $1 \times 10^{-7}$ to $1 \times 10^{-6} \mathrm{~cm} / \mathrm{s}$. Soil used for backfill. should have a sufficient fines content to ensure low permeability of the wall. A fines content that is $30 \%$ finer than a number 200 sieve $(74 \mu \mathrm{m})$ is considered adequate (EPA 1986). Backfill usually contains 6 to $12 \%$ bentonite (a $9 \%$ bentonite mixture was used in this analysis). Although excavated. soil is normally used for backfill, borrow soil would be used in this case because the excavated soi] might be contaminated.

A slurry wall can be placed either upgradient or downgradient of the contaminated zone, or it can be installed in a circumferential configuration completely encompassing the contaminated zone. Although the circumferential configuration is the most common and offers several advantages, it was not applied in this case because it would require slurry wall construction north of the quarry for complete containment. An upgradient placement could be used to divert clean groundwater around the contaminated zone north of the slough. However, this system would also require slurry wall construction north of the quarry and would not completely stop any potential contaminant migration south of the slough. Downgradient placement of the slurry wall was used in this analysis.

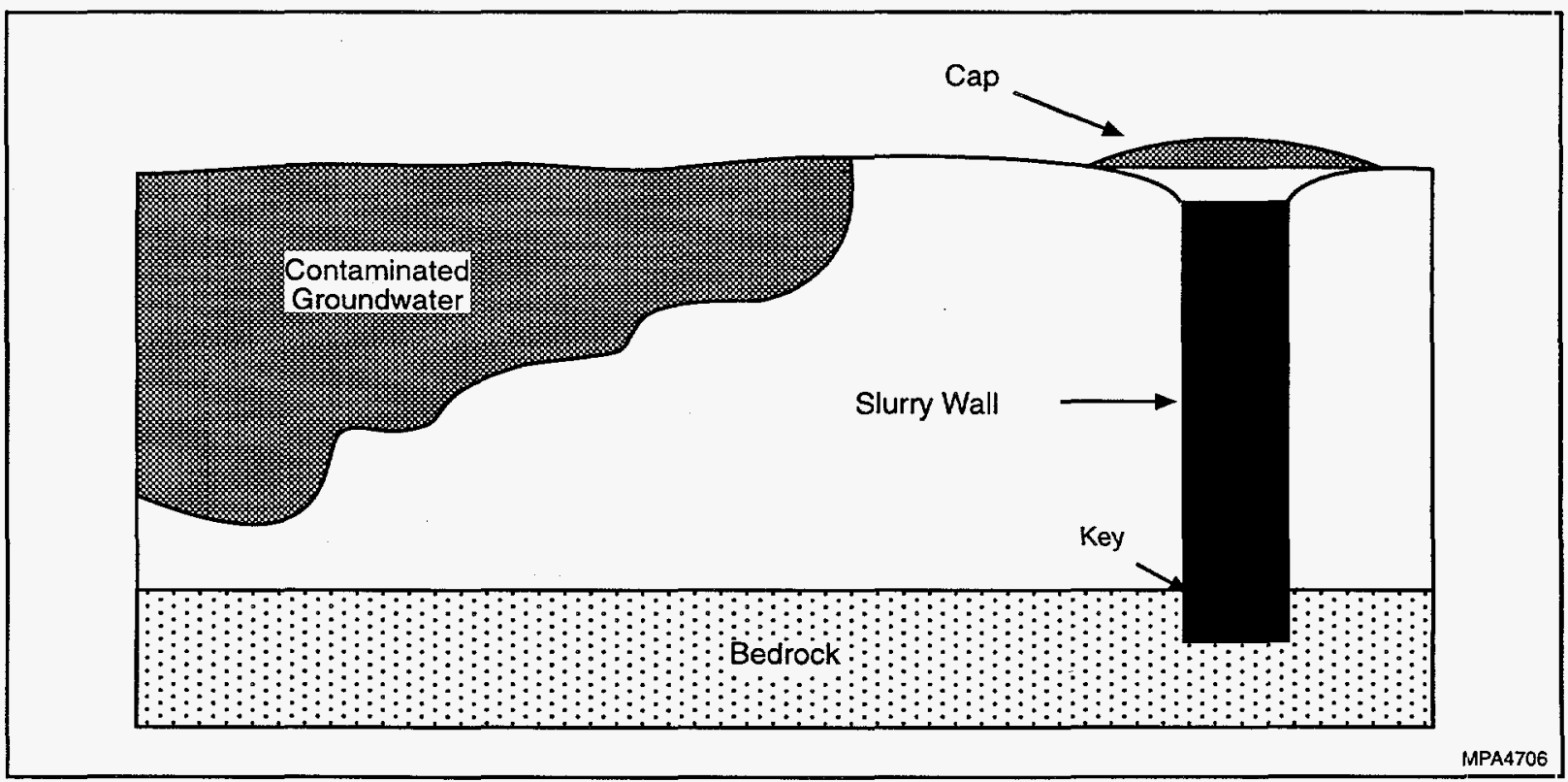

FIGURE 3.4 Schematic of Typical Keyed-In Slurry Wall System (Source: Modified from Marks et al. 1994) 
Only about $6,600 \mathrm{~m}^{3}\left(8,600 \mathrm{yd}^{3}\right)$ of solids would be excavated for Alternative 4 . The volume would be less than that for Alternative 3, because only a single trench would be required for Alternative 4. An approach similar to that identified for Alternative 3 would be used to manage the excavated materials.

Air monitoring would be in place to detect airborne contaminants generated during remedial activities so that appropriate mitigative measures could be taken, if needed. Long-term air monitoring would be implemented following completion of construction to ensure detection of any potential airborne releases of contaminants as a result of system failure.

Because of the low lateral velocity of the contaminated groundwater within the quarry area, it was assumed for this analysis that no subsurface drains would be needed to remove groundwater that might collect at the vertical slurry wall and cause its premature failure. It was also assumed that hydraulic forces would be insufficient to cause premature failure of the slurry wall. (The pressure drop across the vertical slurry wall was estimated to be about $3 \times 10^{-4}$ psi on the basis of a slurry wall thickness of about $1 \mathrm{~m}$ [ $3 \mathrm{ft}$ ] and applying Darcy's Law using the hydrologic values given in DOE [1998b].) Actual requirements for subsurface drains would be defined during the remedial design phase, when the detailed sequencing and implementation plans would be prepared.

Environmental monitoring would continue to the extent necessary to ensure long-term performance of the remedy. Groundwater would be routinely sampled and analyzed to monitor the long-term effectiveness of Alternative 4. Because contamination would remain in the groundwater at concentrations above levels that allow for unlimited use and unrestricted exposure, reviews would be conducted every five years to ensure that the remedy continued to provide adequate protection of human health and the environment. Contingency measures would be considered if it was determined that future further migration of residual contamination resulted in unacceptable concentrations at the St. Charles County well field.

About one to two years would be needed to implement Alternative 4. The design life of the vertical slurry wall would be about 100 years, during which time the concentrations of contaminants would decrease due to biodegradation, radioactive decay, infiltration of clean groundwater, and other natural processes.

\subsubsection{Alternative 5: In-Situ Treatment Using Permeable Barriers}

Alternative 5 would involve in-situ treatment of the quarry groundwater by using a permeable barrier to achieve a uranium concentration of $30 \mathrm{pCi} / \mathrm{L}$ in the groundwater immediately north of Femme Osage Slough. A permeable barrier (also called permeable treatment wall and passive treatment wall) is a passive groundwater remediation technique by which contaminants are removed from groundwater as it flows through an in-situ treatment bed. This technique involves the 
use of sorbents or reactive constituents to remove the contaminants or to convert them to nontoxic: constituents as the groundwater passes through the permeable barrier. The contaminants are retained. in a concentrated form by the barrier material, which is replaced after losing its reactive capacity. Permeable barriers have the potential to treat a wide range of contaminants because of the variety of treatment media available. Permeable barriers are best suited for shallow aquifers (less than $30 \mathrm{~m}$. $[100 \mathrm{ft}]$ ) that are bounded below by a layer of low hydraulic conductivity, such as clay or bedrock Because of lower O\&M costs, permeable barriers might offer cost savings for the QROU, as compared with active groundwater remediation techniques such as conventional pump-and-treat: methods. A permeable barrier does not require electricity to extract the groundwater and can be: capped upon completion of removal operations.

A number of sorbents (including clinoptilolite, peat moss, and fly ash) are effective in. removing metals such as uranium from groundwater (Morrison and Spangler 1992). Under Alternative 5, it was assumed that clinoptilolite - a hydrated sodium-potassium-calcium aluminosilicate natural mineral in the zeolite family - would be used because of its effectiveness as an in-situ permeable barrier material for uranium and other radionuclides (Cantrell et al. 1994). It was also assumed to be used because it has been successfully employed as an ion-exchange material to remove radionuclides such as strontium and cesium from wastes produced in the reprocessing of nuclear fuels. The specific choice of treatment media would be determined during the remedial design phase through literature reviews and possibly bench-scale or pilot-scale testing.

A suboption of this alternative considered the use of zero-valent iron as the in-situ treatment media. Recent studies have indicated that zero-valent iron has the capability of remediating both metals and nitroaromatic compounds in groundwater (Cantrell et al. 1995; Agrawal and Tratnyek 1996). Zero-valent iron would be placed in a trench in the flow path of contaminated groundwater. The barrier would permit groundwater to pass through while precipitating reducible metal such as uranium and selectively degrading nitroaromatic compounds. A rough order-of-magnitude cost estimate developed on a preliminary design using zero-valent iron indicated a relatively high capital cost on the order of $\$ 21$ million to $\$ 30$ million, primarily because of the high cost of zero-valent iron (currently around \$372/net ton, including the shipping container [Bryda and Morris 1997]). This suboption was not pursued further because it provides the same degree of protection as the clinoptilolite at an order of magnitude higher cost.

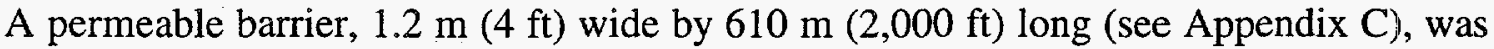
assumed to be located north and east of Femme Osage Slough to contain further spread of contaminants to the slough. (The proposed location of the in-situ treatment system is similar to that shown in Figure 3.2 for the interceptor trench concept.) On the basis of cross-sectional data showing the depth to bedrock as a function of distance from the slough (DOE 1998b), an average depth of $9 \mathrm{~m}$ (30 ft) was applied in this analysis. The actual location, size, capacity, and depth of the in-situ treatment system would be determined during the remedial design phase, at which time 
hydrogeologic characteristics (permeability, thickness of the aquifer, and depth of the affected groundwater) and delineation of the contaminant plume would be taken into account.

This analysis assumed a continuous treatment wall that would stand as a permeable barrier to the groundwater's natural flow and that would not redirect the groundwater. When a permeable barrier is combined with cutoff walls, such as sheet piling or slurry walls, the design is called a funnel-and-gate system. In this arrangement, a low-permeability cutoff wall diverts and funnels groundwater through the higher-permeability treatment wall in a $\mathrm{V}$ shape. A funnel-and-gate system might be more effective because of the increased velocity, which would reduce the amount of required sorbent. However, the redirection in groundwater flow would require a solid barrier at the bottom of the treatment wall for the funnel-and-gate system (Appleton 1996), which would be difficult to construct given that the bedrock in the area of the slough is fractured and has an uneven surface. Also, the duration of the in-situ treatment (more than 200 years [Appendix B]) would preclude the potential use of the lower-cost sheet piling (due to metal corrosion), which would reduce any potential cost savings associated with the funnel-and-gate system. The need to consider a funnel-and-gate system would be defined during the remedial design phase, when detailed sequencing and implementation plans would be prepared.

A permeable treatment barrier would be constructed by excavating a trench that would be shored up by sheet piling. The trench would be excavated to a greater width than the treatment bed to accommodate bracing and excavation equipment. It was assumed that a portion of the material excavated from the trench would be reused as backfill in the trench. Sealable joint sheet piling would be used to reduce groundwater infiltration into the trench during excavation. (A slurry wall was considered for containment purposes, but it would be more expensive than sheet piling and could not be removed after construction to allow natural groundwater flow through the permeable barrier.)

Once the piling was driven and reinforced, the trench would be excavated and the treatment

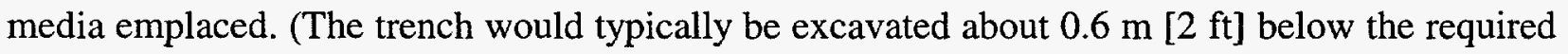
depth in order to key in the wall to the underlying bedrock.) A $0.3-\mathrm{m}$ (1-ft) layer of pea gravel would be placed around the treatment media to filter out particulates that would tend to foul and reduce the efficiency of the clinoptilolite media. The volume of treatment media would be selected such that it would span the height from the bottom of the fill to the height of the water table within the aquifer. Additional treatment media would generally be added to account for seasonal fluctuations in the water table.

A typical treatment bed would be about 1 to $2 \mathrm{~m} \mathrm{(3} \mathrm{to} 6 \mathrm{ft}$ ) thick - the exact thickness would depend on many factors, including the type of contaminants and their concentrations, the contaminants' half-lives through the media, groundwater velocity, and treatment duration. This analysis assumed a $1.2-\mathrm{m}(4-\mathrm{ft})$ thick permeable barrier consisting of $0.3 \mathrm{~m}(1 \mathrm{ft})$ of pea gravel for filtration purposes and a 1-m (3-ft) thick wall of the clinoptilolite media (Appendix $\mathrm{C}$ ). The thickness of the clinoptilolite was determined by assuming an average uranium contamination of $3,000 \mathrm{pCi} / \mathrm{L}$ 
in the inflowing groundwater, a required $99 \%$ capture within the permeable barrier (to achieve a uranium concentration of $30 \mathrm{pCi} / \mathrm{L}$ in the outflowing groundwater), a groundwater flow rate of $0.6 \mathrm{~L} / \mathrm{s}(10 \mathrm{gpm}$ ) (which is based on the approximate discharge from the upper portion of the bedrock: system given in DOE [1998b]), and an adsorptive capacity of $84 \mathrm{pCi}$ of uranium per gram of the clinoptilolite media (Morrison and Spangler 1992). The clinoptilolite would adsorb uranium for a period of approximately 14 years before replacement would be necessary (see Appendix C).

The treatment wall would be capped to reduce erosion and infiltration of precipitation and to provide a protective barrier layer. Clean backfill would be placed over the cap layer, and the: excavated areas would be regraded and revegetated. The sheet piling would be removed to allow natural flow of the groundwater through the permeable barrier. A typical keyed-in permeable barrier system is illustrated in Figure 3.5.

The effectiveness of a permeable barrier system is uncertain because of the potential loss of reactive capacity over time. This analysis assumed that monitoring wells would be installed within: the treatment media to track the sorption of uranium onto the clinoptilolite. Process monitoring wells: would be constructed by installing vertical pipes in the excavation before the media was emplaced. For this analysis, it was assumed that the process monitoring wells would span the depth of the: trench. The emplacement of media and packing (pea gravel) around the pipes would secure the pipes: in place. Groundwater would be monitored at three colinear points as it flowed through the permeable barrier: the first sample would be obtained at the front of the treatment bed, a second. sample would be obtained midway through the treatment bed, and a third sample would be obtained. at the back of the treatment bed. It was assumed that water from these wells would be sampled. quarterly.

Approximately $8,700 \mathrm{~m}^{3}\left(11,400 \mathrm{yd}^{3}\right)$ of solids would be excavated because only a single trench would be required for Alternative 5, as compared with the two trenches needed for Alternative 3. An approach similar to that identified for Alternative 3 would be used for management of the excavated materials.

The air would be monitored to detect airborne contaminants generated during remedial activities and to permit implementation of appropriate mitigative measures. Long-term air monitoring would be implemented following completion of construction to ensure detection of any potential airborne releases of contaminants due to failure of the monitoring wells.

The site would continue to perform environmental monitoring to the extent necessary to ensure long-term performance of the system. The time required for in-situ treatment for Alternative 5 is conservatively predicted to be at least 200 years (see Appendix B). 


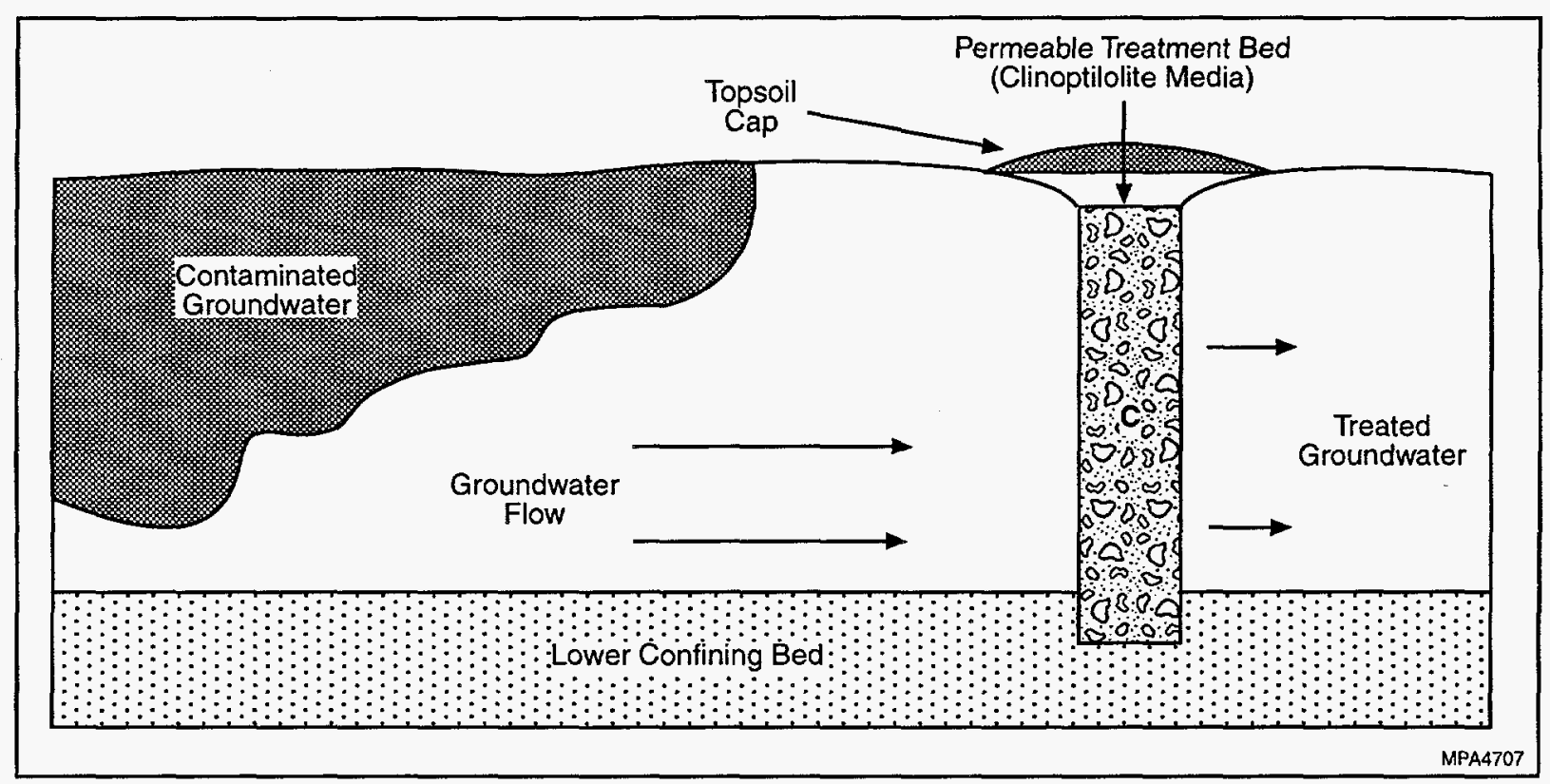

FIGURE 3.5 Schematic of Typical Keyed-In Permeable Barrier System (Source: Modified from Marks et al. 1994)

\subsubsection{Alternative 6: Groundwater Removal at Selected Areas, with On-Site Treatment}

Alternative 6 would involve extraction and treatment of the quarry groundwater from selected areas in the aquifer (areas of localized high contaminant levels) to reduce the amount of uranium that could potentially migrate toward south of the Femme Osage Slough into the St. Charles County well field. This alternative combines active remediation in areas of high concentration with the approach applied in Alternative 2 for management of other areas of the contaminated aquifer with lower concentration portions of the plume. In agreement with current EPA guidance (EPA 1996b; EPA 1997), Alternative 6 considers a phased response action; extraction and treatment would be performed to reduce the mass of uranium within the alluvial aquifer, followed by long-term monitoring to demonstrate that natural processes could result in further lowering the uranium concentrations in quarry groundwater. Monitoring via sampling and analysis of groundwater would be performed during the action period at specified locations in order to verify performance of the action and that uranium concentrations south of the well field (including the well field) are still protective of human health. The long-term monitoring activity is similar to that described for Alternative 2.

Figure 3.6 shows the estimated reduction in mass of uranium within the area of the contaminated alluvium achieved via this alternative, assuming a value of $5 \mathrm{~mL} / \mathrm{g}$ for the partitioning coefficient $\left(\mathrm{K}_{\mathrm{d}}\right)$ of uranium and an initial mass of $1,200 \mathrm{~kg}\left(8 \times 10^{11} \mathrm{pCi}\right)$ in the groundwater in the area of the contaminated alluvium (DOE 1998b). Assuming that the groundwater extraction design 
flow rate of $1.3 \mathrm{~L} / \mathrm{s}(20 \mathrm{gpm})$ can be achieved, approximately 8 to $10 \%$ of the initial uranium mass is predicted to be removed within the first two years of operation. The actual decrease in mass of uranium in the contaminated alluvial aquifer may differ from that shown in Figure 3.6, depending on how representative assumptions are of field conditions. For example, although the $\mathrm{K}_{\mathrm{d}}$ value of $5 \mathrm{~mL} / \mathrm{g}$ is an actual field measurement, it may be representative of only the location where it was measured. The use of this value for the whole area addressed, however, is expected to conservatively bound the shortest remediation time.

As noted in Presumptive Response Strategy and Ex-Situ Treatment Technologies for Contaminated Ground Water at CERCLA Sites (EPA 1996a), extraction and treatment may not be the best method for addressing large areas of a contaminated aquifer with heterogeneous (mostly low) contaminant levels. In these cases, the most appropriate approach for addressing the contaminated aquifer may be extraction and treatment to reduce those plume areas with relatively high concentrations of dissolved contamination. Further, for contamination that exists in a shallow portion of the aquifer, the use of interceptor trenches can be more cost effective than extraction wells. This is particularly true in strata with low or variable hydraulic conductivity. An interceptor trench system is usually designed to either intercept the downgradient flow of a contaminant, or it is placed throughout the plume as a collection system. For this alternative, contaminated groundwater from selected areas in the alluvial aquifer north of the Femme Osage Slough would be extracted using an interceptor trench. Remedial activities implemented under this alternative include groundwater removal using an interceptor trench located in a line between monitoring wells MW1016 and MW-1014, treatment of the extracted groundwater at either the QWTP or a portable groundwater treatment facility, and release of treated groundwater via a permitted discharge point.

The conceptual design of the groundwater removal system is similar to that considered in

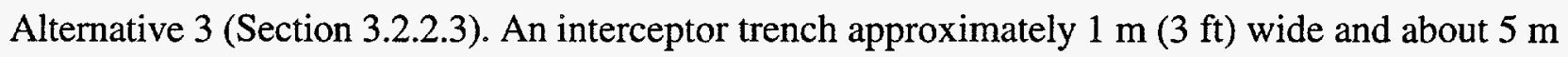
( $16 \mathrm{ft}$ ) deep composed of aggregate encased slotted HDPE pipe would be constructed north of the Femme Osage Slough in an area bounded by and encompassing wells MW-1014 and MW-1016, a distance of approximately $340 \mathrm{~m}(1,100 \mathrm{ft})$. (The hypothetical location of the groundwater removal system is shown in Figure 3.7.) The actual location, size, capacity, and depth of the interceptor trench would be determined during the remedial design phase and would take into account hydrogeologic characteristics (permeability, aquifer thickness, and depth of the affected groundwater) and the delineation of the groundwater contamination where the greatest concentrations of uranium are measured.

The maximum possible extraction rate for an interceptor trench with a length of $340 \mathrm{~m}$ $(1,100 \mathrm{ft})$ is estimated to range from approximately 0.6 to $1.3 \mathrm{~L} / \mathrm{s}$ (10 to $20 \mathrm{gpm})$. Alternative 6 was based on the assumption of an upper extraction rate of approximately $1.3 \mathrm{~L} / \mathrm{s}(20 \mathrm{gpm})$. This alternative assumes that the on-site treatment plant (QWTP) would be available to treat the extracted 

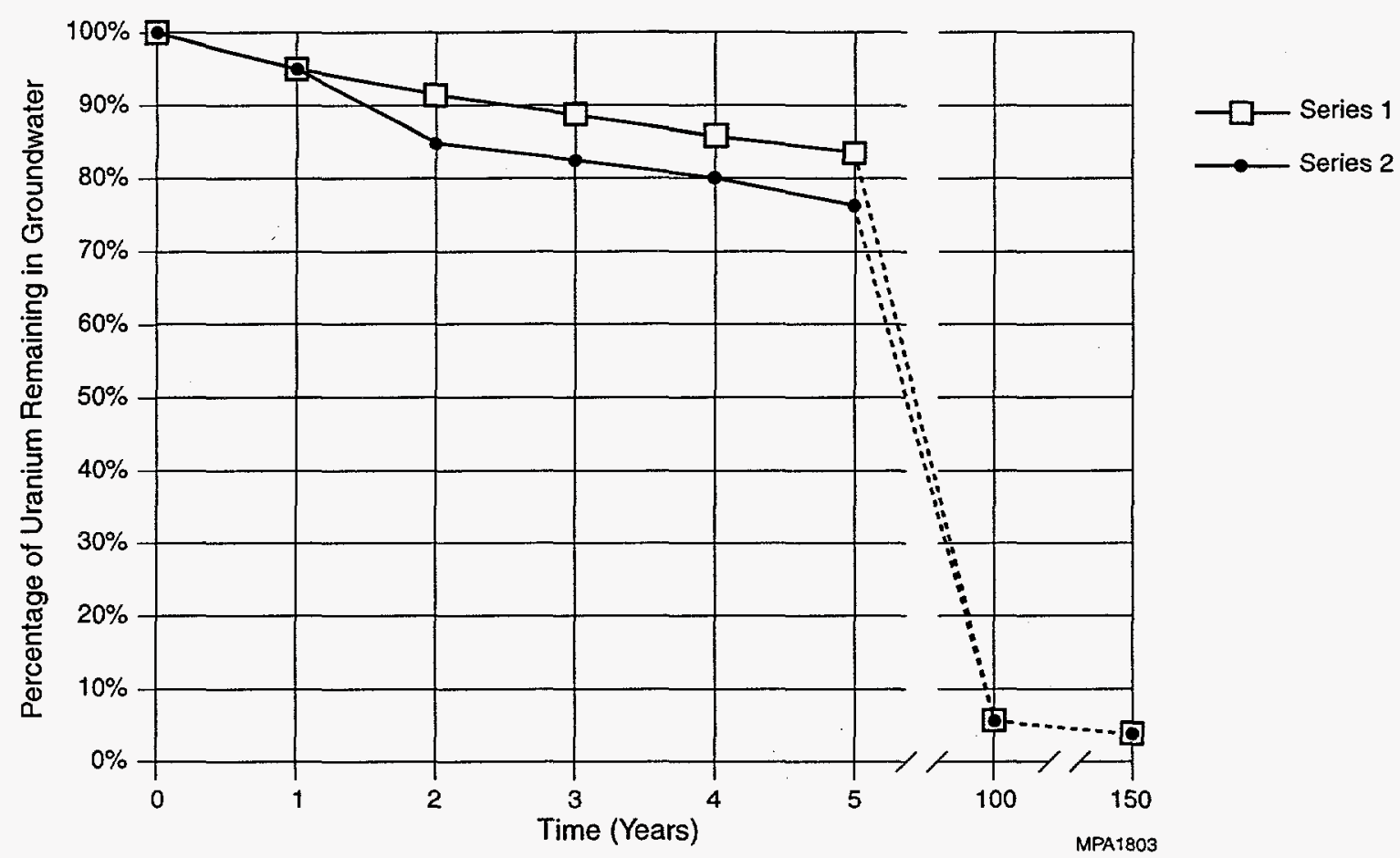

FIGURE 3.6 Predicted Percentage of the Mass of Uranium Remaining in the Groundwater in the Area of the Contaminated Alluvium North of the Femme Osage Slough during Remediation

groundwater. (A description of the treatment capabilities of the QWTP is provided in Section 3.2.2.3.) However, it may be possible that the QWTP is either unavailable (due to limited design life or dismantlement as a result of other site-related activities such as those involving quarry restoration), or that the low flow rate of extracted groundwater makes it uneconomical to operate and maintain the QWTP. In this case, the extracted quarry groundwater would be treated at a portable facility on-site. In both cases, the treated groundwater would be discharged to a permitted discharge point. Reinjection of the treated groundwater back into the aquifer was not considered feasible nor desirable because of the low permeability and porosity of the formation. Details on constructing an interceptor trench are provided in Section 3.2.2.3.

One major difference in design in Alternative 6, compared with Alternative 3, is the absence of a slurry wall because of the greater distance of the interceptor trench in Alternative 6 from the Femme Osage Slough. If necessary, a 13-cm (5-in.) thick HDPE liner on the outside wall of the interceptor trench was estimated to provide adequate strength to maintain structural integrity to ensure containment. The necessity for containment provided by the HDPE liner would be determined during the final design, at which time the proximity of the interceptor trench to the Femme Osage Slough would be taken into account. This analysis assumed that a total of six sumps would be placed along the length of the interceptor trench to collect and remove the groundwater, on the basis of the methodology provided in the French Drain System for Site Remediation (Naval Energy and Environmental Support Activity 1991). The actual number of sumps would be determined during 


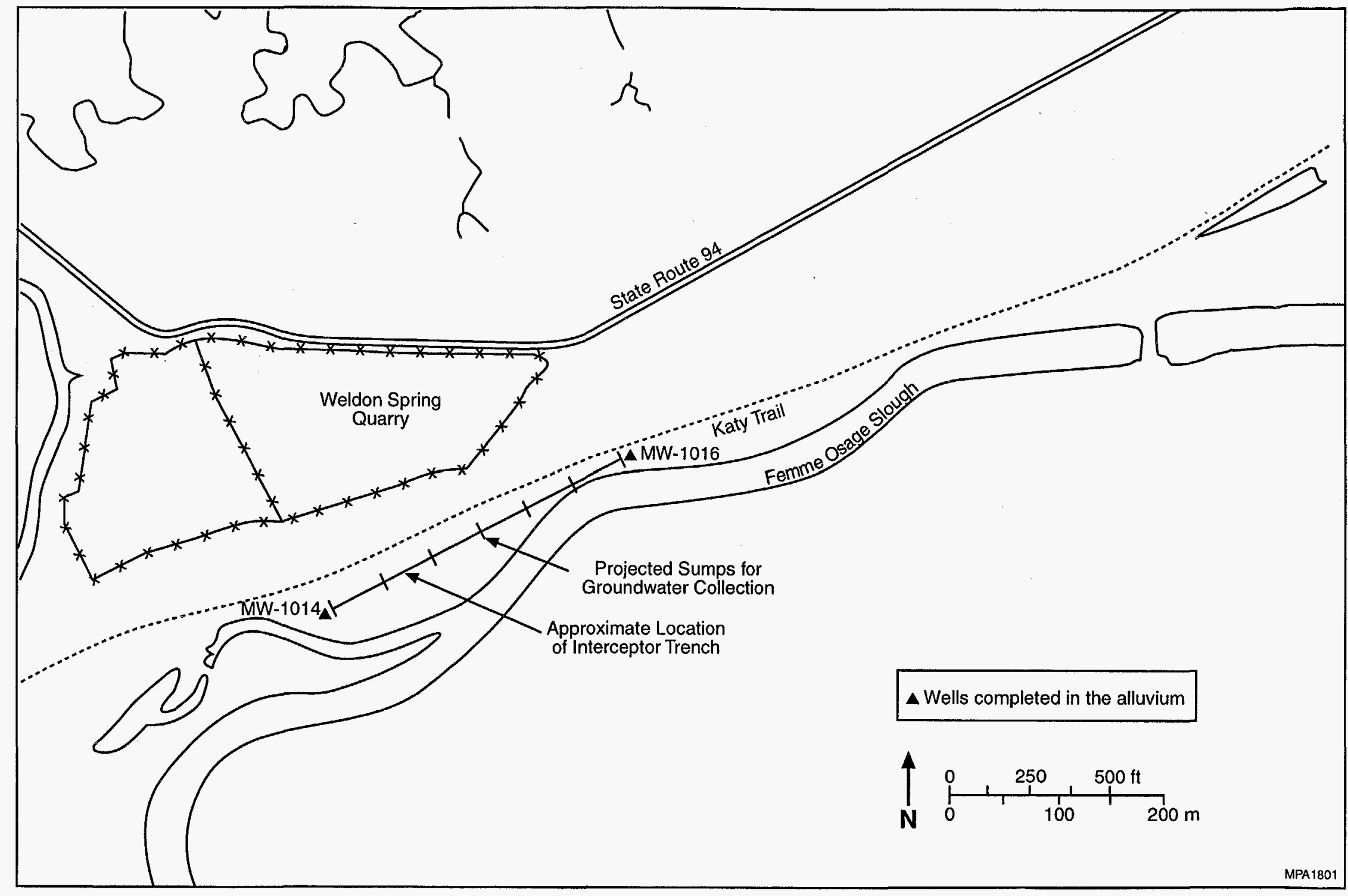

FIGURE 3.7 Location of the Proposed Groundwater Extraction System for Alternative 6 
the final design, at which time the variation in the elevation of the top of the bedrock would be considered. This analysis assumed a passive system (i.e., without groundwater gradient control), with groundwater pumps included for the purpose of evacuating the sumps.

An area of approximately 0.4 ha ( 1 acre) would initially be cleared of vegetation to contain the interceptor trench. About $2,100 \mathrm{~m}^{3}\left(2,800 \mathrm{yd}^{3}\right)$ of material would be excavated in the development of the trench. For costing purposes, this analysis was based on the assumption that the excavated solids would be brought to the chemical plant area at the Weldon Spring site for either direct placement in the on-site engineered disposal facility or temporary stockpiling until placement could take place. These soils could also be used for backfill in the quarry, depending on the contaminant level. Wastewater generated during construction activities, such as trench dewatering (on the order of $140,000 \mathrm{~L}$ [38,000 gal], on the basis of a total of about $1,600 \mathrm{~m}^{3}\left[56,000 \mathrm{ft}^{3}\right]$ excavated and a backhoe excavation rate of $100 \mathrm{~m}^{3} / \mathrm{h}\left[130 \mathrm{yd}^{3} / \mathrm{h}\right]$ ), would either be stored and then transported to the QWTP for treatment or be treated by the mobile treatment unit prior to release to the Missouri River via the 10-cm (4-in.) QWTP PVC pipeline.

Work area monitors would be used during remedial activities such as earthmoving to assure that contaminant levels in the air are maintained within established limits so that appropriate mitigative measures could be taken if any airborne contamination was detected. The continuously operating air monitoring network that has been in place since 1986 at the WSSRAP to measure levels of gamma radiation, radioactive dust particles, and radon gas at the quarry fence line would be used to compare measured levels to naturally occurring levels to determine whether additional controls would be needed. Environmental monitoring would be continued to the extent necessary to ensure long-term performance of the remedy.

The drain within the interceptor trench consists of a $0.15-\mathrm{m}(0.5-\mathrm{ft})$ perforated PVC collection pipe surrounded by a gravel pack. This system also assumes a geotextile liner in the collection trenches to prevent clogging and filling of the pipe with silts and sands. Replacing the geotextile liner with a filter sock placed on the pipe or gradation of the gravel to prevent clogging may be considered in the final design. Contaminated groundwater enters the drain and flows by gravity to the sumps. Groundwater pumps in the sumps deliver the contaminated groundwater to an aboveground tank before being pumped to a treatment facility. A double-wall PVC pipeline would be constructed to transfer the water from the interceptor trench storage tank for treatment.

In the case in which the extracted groundwater would be treated at the QWTP, a pipeline would be constructed connecting the discharge of the interceptor trench with the QWTP. The following text describes a typical scenario for the potential use of the QWTP. (Based upon the quarry restoration project, the QWTP could be modified, and the equalization basin may not be available, in which case a tank would be used for storage prior to batch treatment at the QWTP). Groundwater would be pumped from the interceptor trench to the existing equalization basin at the QWTP. The equalization basin serves as a reservoir to provide consistent flow and uniform contaminant 
concentration at the QWTP. The water then goes to the QWTP for a series of treatment processes to remove uranium, nitrates, and other chemical contaminants (see Section 3.2.2.3). The QWTP would be operated on a campaign mode, that is, whenever the equalization basin would contain sufficient groundwater for continuous operation of the water treatment process.

Portable treatment units would be used if the QWTP was unavailable. A number of nobile treatment options are available, including fixed, skid-mounted systems and trailer-enclosed systems. A trailer-mounted unit was assumed in this analysis to facilitate ease of transportation of the unit to the area north of the Femme Osage Slough and to allow removal of the trailer-mounted system in the event of flooding of the Missouri River in the region of the quarry.

The portable groundwater treatment facility would consist of one or more trailer-mounted. treatment modules (Shropshire et al. 1995). Each trailer would be standard roadway size: $2 \mathrm{~m}(8 \mathrm{ft}$ )

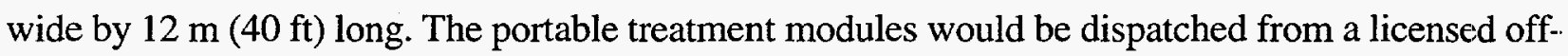
site contractor's home office to the Weldon Spring site by a licensed commercial shipping firm. Once on site, the portable treatment modules would be set on pads equipped with secondary containment. The portable treatment modules would be interconnected to form an integrated. treatment facility, and utilities such as service water and electric power would be attached. Preoperational checkout and safety checks would be performed prior to full-scale operations.

Figure 3.8 is a preconceptual process flow diagram for groundwater treatment using portable units. (The system described here is primarily for purposes of illustration [to help the reader understand what would be involved in treating groundwater using portable units]; it is not intended as a final or definitive treatment system. Other treatment processes or system configurations could be used, provided they are capable of cost effectively achieving the required effluent concentrations.) The treatment capabilities of the portable unit would include sedimentation, filtration, chemical treatment, and ion exchange. The nominal treatment capacity of the portable units would be $1.3 \mathrm{~L} / \mathrm{s}$ (20 gpm). Concentrated waste sludge generated by the groundwater treatment process would be dewatered, stabilized by cementation, packaged, and shipped off-site for disposal. Spent treatment media (e.g., exhausted ion-exchange resin and spent activated carbon) would be cement stabilized and managed, consistent with current site practice. On the basis of a maximum possible extraction rate of $1.3 \mathrm{~L} / \mathrm{s}$ (20 gpm), continuous removal (8,760 hours per year), and a density of $1.8 \mathrm{~g} / \mathrm{cm}^{3}$ $\left(112 \mathrm{lb} / \mathrm{ft}^{3}\right)$ for the solidified waste (Shropshire et al. 1995), the annual amount of stabilized spent resin and spent carbon generated during waste water treatment is estimated to be approximately $5 \mathrm{~m}^{3}$ $\left(200 \mathrm{ft}^{3}\right)$. Any spent resin and carbon generated following closure of the on-site disposal facility would be packaged for off-site shipment and disposal. Assuming packaging in a standard 55-gal drum and truck transport, less than one annual off-site shipment to a licensed disposal facility would be required. The maximum radioactivity of the groundwater treatment residuals for this alternative would be similar to that generated for Alternative 3 (on the order of about $200 \mathrm{pCi} / \mathrm{g}$ of uranium). 


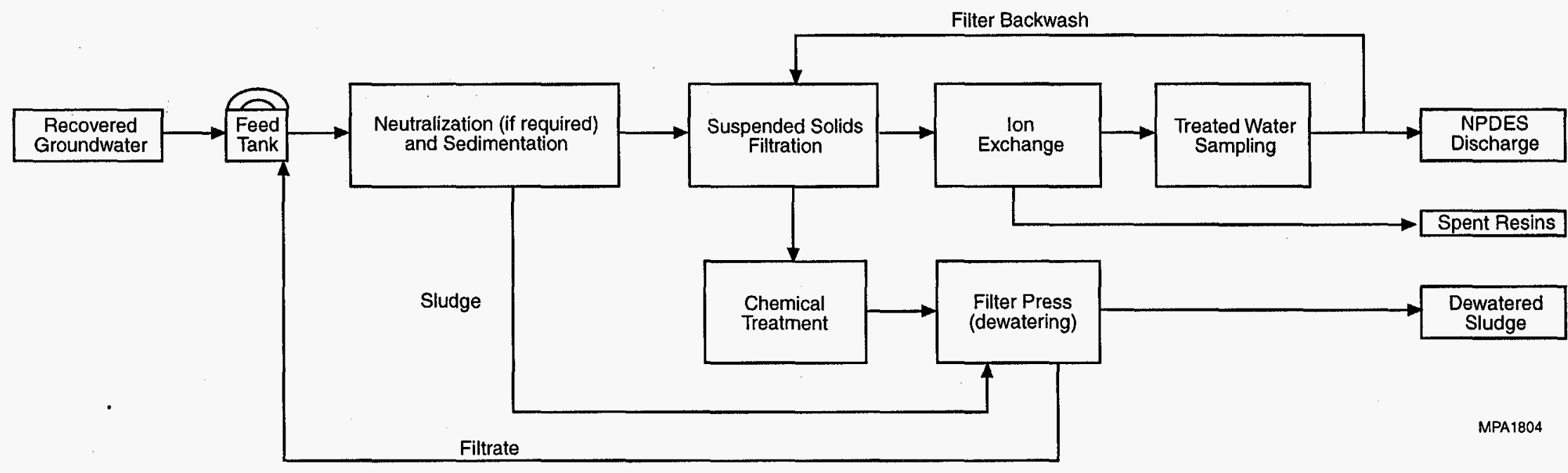

FIGURE 3.8 Preconceptual Process Flow Diagram for Groundwater Treatment Using Portable Units 
The treated water from the portable facility would be tested to verify that the treatments had reduced contaminant concentrations to permissible levels and to confirm compliance with discharge: requirements. Treated water meeting these requirements would be discharged into the Missouri River.

At the end of the treatment campaign, the modules would be decontaminated by treating; all waste through the portable facility and completely flushing and draining each piece of equipment: that has been in contact with the groundwater. Waste generated during decontamination would be treated and disposed of as required. After decontamination, the interior and exterior of the portable: units would be assayed and inspected before disassembly and removal from the site.

After construction of the interceptor trench and (if necessary) associated groundwater treatment system, the two systems would be carefully monitored on a regular basis and their performance evaluated. Operation and monitoring for a period of up to two years would be: conducted to collect sufficient information to determine performance of the remedial action. The performance of the proposed remedy would, therefore, be evaluated after two years to compare anticipated with actual results (actual performance in the field may vary from that assumed during design, given uncertainties about subsurface geology prior to construction and operation), to identify any potential deficiencies in the remedy's protectiveness, and to identify opportunities to optimize its performance. (The period of extraction and treatment for Alternative 6 is conservatively predicted to range from 50 to over 1,000 years to achieve a final uranium cleanup limit of $30 \mathrm{pCi} / \mathrm{L}$ within the quarry alluvial groundwater, on the basis of the observed range of 2.5 to $50 \mathrm{~mL} / \mathrm{g}$ for the partitioning coefficient $\left[\mathrm{K}_{\mathrm{d}}\right]$ in the alluvial aquifer north of the Femme Osage Slough and remediation of the contaminated groundwater contained between the interceptor trench and monitoring wells MW-1048 and MW-1005. This duration is governed by the natural groundwater flow within the alluvial aquifer and the contaminant concentrations. The predicted uranium concentrations collected by the interceptor trench as a function of time are provided in Table 3.1 and are based on a $\mathrm{K}_{\mathrm{d}}$ of $5 \mathrm{~mL} / \mathrm{g}$.)

\subsection{CRITERIA FOR SCREENING ALTERNATIVES}

As defined in the NCP, the development and screening of remedial alternatives should be guided by three criteria: effectiveness, implementability, and cost. Effectiveness focuses on (1) the degree to which an alternative reduces toxicity, mobility, or volume through treatment; minimizes residual risks; affords long-term protection; complies with ARARs; and minimizes short-term impacts; and (2) how quickly it achieves protection. Both short-term and long-term effectiveness are evaluated. Short-term effectiveness refers to the active remediation period when construction and implementation activities are performed, whereas long-term effectiveness refers to the period after the remediation activities have been performed. 
Implementability focuses on the technical feasibility and availability of the technologies needed for an alternative and the administrative feasibility of implementing that alternative. Timeliness of implementation, potential interference with site operations, and potential future maintenance needs are also considered.

The cost criterion considers construction costs and any long-term costs to operate and maintain an alternative. A general cost analysis is applied to identify alternatives that are significantly more costly than other alternatives that can achieve the same level of risk reduction (EPA 1988b). Costs considered in this screening process are only approximate; an alternative is screened out if it would be clearly an order of magnitude more expensive than other alternatives providing the same degree of protection.

\subsection{SCREENING OF PRELIMINARY ALTERNATIVES}

\subsubsection{Alternative 1: No Action}

Alternative 1, which would involve no passive or active response action, is described in Section 3.2.2.1. The No Action Alternative provides a baseline for comparison with the other alternatives.

\subsubsection{Effectiveness}

Alternative 1 would provide no reduction in the risk to human health posed by the contaminated groundwater, other than through natural processes, including reduction of the nitroaromatic compounds by biodegradation and attenuation of the uranium by sorption in alluvial sediments, precipitation, and dilution of the contaminated groundwater with uncontaminated groundwater from the Missouri River. Alternative 1 would allow for the possible continued migration of the 
contaminant plume and potential further degradation of the groundwater within the quarry and the land just south of the quarry and north of Femme Osage Slough. No reduction would occur in the toxicity, mobility, or volume of the contaminated groundwater through treatment. No short-term impacts would occur to the public, workers, or the environment during construction or: implementation because no remedial action would be conducted. Under current conditions, the; groundwater north of the slough poses no imminent risk to human health at the St. Charles County well field or the environment south of the slough. However, protection of human health and the environment in the extended future could not be ensured because all investigative and monitoring; activities would end.

\subsubsection{Implementability}

No implementability concerns would be posed by Alternative 1 because no action would be taken nor would any future activities be considered. No technologies or management strategies would be implemented, nor would any permits, licenses, or approvals associated with undertaking, a remedial action be needed.

\subsubsection{Cost}

No net present worth, capital, or annual O\&M costs are associated with the No Action Alternative because no activities would be undertaken.

\subsubsection{Alternative 2: Monitoring with No Active Remediation}

Alternative 2 would involve the implementation of routine sampling and analyses to monitor the possible continued migration of the contaminant plume and the imposition of institutional controls to prevent the potential use of the contaminated groundwater. This alternative is described in Section 3.2.2.2.

\subsubsection{Effectiveness}

Alternative 2 might be protective of human health and the environment over the long term, and unlike Alternative 1, monitoring activities by DOE under Alternative 2 would be used to provide data to identify any potential future plume migration. These data could also be used to determine any variations in local geochemical conditions (such as Eh and $\mathrm{pH}$ ) that could adversely affect removal of the contaminants from the groundwater by precipitation, biodegradation, and other natural means. Such activities would verify whether uranium concentrations are decreasing through 
natural processes and whether uranium concentrations at the St. Charles County well field are still protective of human health and the environment. Contingency measures would be considered if future further migration of residual contamination resulted in unacceptable exposure concentrations at the St. Charles County well field. On the basis of the results summarized in Section 1.3, unacceptable impacts to human health and the environment would not be expected to occur.

The potential short-term environmental impacts associated with Alternative 2 would be the lowest among any of the action alternatives. Short-term impacts would primarily be the physical hazards to workers during construction and operation of monitoring wells, minor criteria pollutant emissions during any construction activities, and disturbance of soil and resulting airborne dust emissions. Appropriate mitigative measures would be enacted during construction and operations to protect workers and members of the public. Air would be monitored to ensure that the controls were working. Protective equipment would be used, and dust suppression methods would be enacted to minimize short-term risks to workers.

For Alternative 2 to remain effective over the long term, careful consideration would have to be given to monitoring, maintenance, and control. A time frame of about 100 to 1,000 years would be expected for the uranium concentrations to decrease to $30 \mathrm{pCi} / \mathrm{L}$ and lower, primarily because of the natural processes that are expected to occur. Because this alternative would result in contamination remaining on-site at concentrations above levels that allow for unlimited use and unrestricted exposure, a review would have to be conducted at least every five years to ensure that the remedy continued to provide adequate protection of human health and the environment.

Alternative 2 would not satisfy the statutory preference for treatment as a principal element of remediation, and there would be no reduction in toxicity, mobility, or volume of the contaminated groundwater through treatment. Residual contamination would remain high in the short term; however, the concentrations of contaminants in the area of the quarry would be expected to decrease with time because of the removal of the original source of contamination (i.e., the bulk waste) from the quarry and because of reduction and dilution processes.

\subsubsection{Implementability}

Few implementability concerns would be posed by Alternative 2 because of the limited actions required. The proposed monitoring would provide warning of failure before significant exposure occurred. Therefore, taking additional actions prior to significant exposure would be relatively easy to implement.

Monitoring of plume migration would also be relatively easy to implement. No special equipment would be required, and analytical procedures exist to determine the presence of groundwater contaminants (such as uranium) in samples drawn from the monitoring wells. Construction 
of any proposed monitoring wells would require mobilization of a drilling rig for installation; eight: wells were recently installed to support the remedial investigation of the quarry area (DOE 1998b). Resources required for maintenance of the existing and any proposed groundwater monitoring systems should be readily available. New permits for installation of the proposed groundwater monitoring wells would be required to implement Alternative 2.

\subsubsection{Cost}

The estimated cost of Alternative 2 is relatively low; it would be the least expensive of all the action alternatives. In general, expenses associated with institutional control and monitoring would be low. Capital expenses would include the construction of any proposed monitoring wells and the routine replacement of existing equipment for groundwater monitoring. Given the low replacement costs compared with the capital cost for monitoring well installation, the cost of routine equipment replacement was not considered. On the basis of this preconceptual design and the application of cost factors specific to the Weldon Spring site for indirect activities (Hood 1997), the capital cost of Alternative 2 is estimated to be approximately $\$ 0.15$ million (Appendix E).

Annual expenses would be incurred for the groundwater monitoring program. The annual cost of operating the proposed monitoring wells was estimated on the basis of the current costs for the existing monitoring well network. The annual O\&M cost is estimated to be about $\$ 0.6$ million. Per EPA guidance, the annual costs were discounted to a current value using a discount rate of $7 \%$ (before taxes and after inflation) (EPA 1993b) and a time period of 30 years (EPA 1988a). The 30 -year present worth of Alternative 2 is estimated to be approximately $\$ 7$ million, which is the lowest of all the action alternatives.

The costs associated with potential future actions (e.g., in the event that migration of residual contamination resulted in unacceptable exposure concentrations) were not quantified, because the uncertainty associated with these future activities precludes accurate cost assessment.

\subsubsection{Alternative 3: Groundwater Removal with On-Site Treatment}

Alternative 3 would involve the extraction of contaminated groundwater with interception trenches and treatment of the water on-site at the existing QWTP or a similar facility (see Section 3.2.2.3). 


\subsubsection{Effectiveness}

Alternative 3 would protect human health and the environment by remediating the contaminated groundwater. Upon completion of the remediation, the uranium concentration in the groundwater within the quarry area and the land north of the slough would be below the metric of $30 \mathrm{pCi} / \mathrm{L}$. In addition, contaminant migration south of the slough would be largely halted upon implementation of this alternative, and any potential for future large-scale contamination of the St. Charles County well field would be effectively prevented. Alternative 3 would be expected to attain all contaminant-specific and action-specific ARARs when remediation was complete.

Alternative 3 would reduce the volume of contaminants through treatment and would afford long-term protection. After completion of remediation, no long-term action would be required.

The potential short-term impacts associated with Alternative 3 would include the physical hazards to workers during construction of the interceptor trench and slurry wall systems and during operation of the extraction and treatment systems. Other potential short-term impacts would be associated with criteria pollutant emissions (e.g., carbon monoxide [CO], nitrogen oxides $\left[\mathrm{NO}_{\mathrm{x}}\right]$, and sulfur oxides $\left[\mathrm{SO}_{\mathrm{x}}\right]$ ) resulting from construction activities and airborne dust emissions resulting from soil disturbance during site clearing, trench excavation, and regrading. Appropriate mitigative measures would be taken during construction and operations to protect workers and members of the general public. Engineering controls, such as spraying water for dust suppression, would be used to minimize short-term risks to the public, and air monitoring would be used to ensure that the controls were working. Protective equipment would be used for workers, and dust suppression methods would be enacted to minimize short-term risks. The short-term impacts of Alternative 3 would be the highest among all alternatives.

Under Alternative 3, it is estimated that at least 200 years or more of remediation would be required to achieve remediation goals (i.e., a uranium concentration of $30 \mathrm{pCi} / \mathrm{L}$ in groundwater) (see Appendix B). The uncertainty regarding the projected geochemical properties of the contaminants within the groundwater system might, however, preclude being able to adequately extract the contaminants to attain acceptably low concentrations.

\subsubsection{Implementability}

The proposed groundwater extraction technology for Alternative 3 has been widely used and found reliable if the system has been properly constructed and maintained. However, a number of implementability concerns would be posed for this application. For example, difficulties would exist regarding trench construction because the required trench depth would be greater than $1.5 \mathrm{~m}$ (5 ft). This would necessitate taking extra precaution pursuant to current Occupational Safety and Health Administration (OSHA) requirements for avoiding potential failure of trench walls. 
Reinforcement, anchoring, and dewatering during construction might be necessary. At the quarry area, the fine-grained alluvium consists of silty clay and clayey silt, whereas the coarse-grained subsurface materials consist of fine-grained to medium-grained sand with some silt; these materials grade with depth to coarse-grained sand with cobbles and boulders (DOE 1998b). As with all excavation techniques, the presence of large rocks (boulders) and cobbles in the underlying lithology would increase installation costs. In addition, such a condition might even prohibit installation of the interceptor trench and slurry wall systems because the presence of boulders upstream of the interceptor trench would result in local flow channeling.

No major difficulties would be anticipated for maintenance of the groundwater extraction system or use of the existing QWTP over the short term. However, the design life of the QWTP is only 10 years (1992-2002), after which time, extensive maintenance would be required to continue service beyond the design life (Valett 1997). Replacement of the slurry wall and/or interceptor trench system might be required because of the predicted extraction period of at least 200 years. Groundwater monitoring would be required to track the progress and effectiveness of the groundwater remediation program. Monitoring the treated groundwater prior to its release to the Missouri River would also be required to ensure compliance with discharge limits in the existing NPDES permit.

In general, no special equipment would be needed to implement Alternative 3. However, because of the underlying lithology at the site, detailed studies might have to be conducted to determine whether the interceptor trench and slurry wall systems could be constructed. The proximity of the slough would make it extremely difficult to construct the interceptor trench and slurry wall systems. Resources should be readily available for groundwater monitoring and for maintenance of product pumps and associated controls.

The interceptor trench technology can be considered to be a proven technology (Wagner et al. 1986). Determining the required location for an interceptor trench is more often based on the use of field data than on theoretical design. To function properly, an interceptor trench should be installed perpendicular to groundwater flow direction. Additional subsurface studies (borings) may be required to determine the proper orientation of the trench.

Treatability studies may be needed to accurately predict the site-specific effectiveness and total cost of filtration, ion exchange, precipitation, filter pressing, and other water treatment processes. Three tiers of testing may be undertaken (laboratory screening, bench-scale testing, and pilot-scale testing), depending upon whether the QWTP would be used for groundwater treatment. These studies may be needed during the remedial design phase to aid in the design or implementation of this alternative and would be helpful in selecting among the various groundwater treatment technologies and in improving remedy performance (EPA 1997). 
A major implementability concern for Alternative 3 is the active life of the QWTP, which is estimated to be about 10 years. Twenty equivalent plant lifetimes of treatment capacity or more would be required to meet the estimated treatment duration of at least 200 years. The technical feasibility of this aspect of Alternative 3 appears uncertain, given the potential number of replacement facilities that would be required.

Another major implementability concern is the possibility of flooding. The land between the quarry and the slough is subject to annual flooding; floods have occurred during the last three years. The design for any aboveground equipment would have to consider hardening the facility or possibly the entire quarry area against the effects of floods so that the chance of damage and interruption of operations would be acceptably low. Installation of temporary flood barriers, removal of equipment to protected areas, anchoring of vulnerable items, or installation of sumps or emergency pumps might be needed to mitigate the potential damage to mission-dependent components and systems.

New permits or licenses for on-site activities might be required to implement Alternative 3 . The NPDES permit reissued on June 22, 1994, which allows the discharge of treated water to the Missouri River, might have to be modified to include any potential additional contaminants (e.g., thallium) discharged from the treatment operations.

Another potential implementability concern is the proposed location for the interceptor trench. For this analysis, it was assumed to be situated north of Femme Osage Slough on land located in the Weldon Spring Conservation Area. The land near the slough is administered by the Missouri Department of Conservation and the Missouri Department of Natural Resources; permission from these two agencies would be required before Alternative 3 could be implemented.

Finally, the QWTP is currently located on an easement within the quarry area. Consideration is being given to dismantling and removing the QWTP from its current location to allow regrading and closure of the quarry. In this case, the QWTP (or similar facility) might be relocated near the interceptor trench to treat the extracted groundwater. Protection against flooding would have to be provided if the QWTP (or similar facility) was located near the interceptor trench. The relocation would require the approval of the Missouri Departments of Conservation and Natural Resources.

\subsubsection{Cost}

The estimated cost of Alternative 3 is greater than the costs of the other action alternatives. On the basis of the preconceptual design, application of cost factors specific to the Weldon Spring site for indirect activities (Hood 1997), and the capital cost of replacing the QWTP when its design life was exceeded, the capital cost of Alternative 3 is estimated to be between about $\$ 4$ million and 
$\$ 6$ million (Appendix E). The capital cost would be primarily for the installation of the interceptor trench and slurry wall.

Including the annual operating cost of the QWTP and continued groundwater monitoring, the annual O\&M costs are estimated to be between about $\$ 1$ million and $\$ 2$ million. The annual O\&M costs would be primarily for groundwater treatment. Assuming a discount rate of $7 \%$ per year and replacement of the QWTP every 10 years, the 30-year present worth of Alternative 3 is estimated to be between about $\$ 17$ million and $\$ 26$ million, the highest cost among all the action alternatives.

\subsubsection{Alternative 4: Containment}

Alternative 4 would consist of containment of contaminated groundwater with vertical barriers. This containment would be coupled with implementation of routine sampling and analysis to monitor the long-term effectiveness of the proposed action and with the imposition of institutional controls to prevent the use of the contaminated groundwater. Alternative 4 is described in Section 3.2.2.4.

\subsubsection{Effectiveness}

Alternative 4 would reduce the potential risk to human health posed by the contaminated groundwater by reducing the spread of contaminants to potential exposure points and by reducing the potential for any degradation of the groundwater used for public consumption. Contaminant migration south of the slough would be largely halted upon implementation of this alternative, and any potential future large-scale contamination of the St. Charles County well field would be effectively prevented. Installation has been estimated to take approximately one to two years (Appendix E).

The effectiveness of Alternative 4 would depend on achieving complete continuity of the vertical barrier with no high-permeability zones. Achieving this condition would require control of any sidewall sloughing (and potential trench collapse) during construction, which could result in high-permeability gaps in the slurry wall. Alternative 4 might be expected to become increasingly ineffective in providing hydraulic isolation as the containment performance degraded with time (Marks et al. 1994). Compatibility of the contaminant with the slurry wall is a major concern, especially when the wall must be in direct contact with the contaminant. Certain chemical contaminants (i.e., those with low dielectric constants, high electrolyte concentrations, or high cation valences [Gleason et al. 1997]) can actually increase the permeability of a slurry wall. The compatibility of the contaminant with the proposed backfill would have to be verified early in the design phase through permeability testing of the proposed backfill material with groundwater from 
the quarry area. If necessary, other slurry mixtures would have to be developed if a soil-bentonite mixture would not be able to withstand direct contact with groundwater contaminants at the QROU.

Because clay soils (including bentonite) have an ion-exchange capacity for absorbing metals such as uranium, a slurry wall might have some capacity for removal and/or retardation of radionuclides in groundwater passing through the wall. A treatability study would be necessary to determine the concentration of uranium exiting the slurry wall and the removal capacity of the wall (i.e., the amount of uranium removed per unit volume of wall).

The potential short-term impacts of Alternative 4 would include those associated with the physical hazards to workers during construction of the slurry wall. Other short-term impacts would be associated with criteria pollutant emissions resulting from construction activities and airborne dust emissions resulting from soil disturbance during site clearing, trench excavation, and regrading. Appropriate mitigative measures would be enacted during construction and operations to protect workers and members of the general public. Engineering controls, such as spraying water to suppress dust, would be used to minimize short-term risks to the public, and air monitoring would be used to ensure that the controls were working. Protective equipment would be used for workers, and dust suppression methods would be enacted to minimize short-term risks. Fewer short-term impacts would result from Alternative 4 than from Alternative 3.

For Alternative 4 to remain effective over the long term, careful consideration would have to be given to long-term monitoring, maintenance, and control. Groundwater monitoring would be required to track the condition and effectiveness of the containment barrier. Because Alternative 4 would result in hazardous substances remaining on-site at concentrations above health-based levels, a review would have to be conducted at least every five years to ensure that the remedy continued to provide adequate protection of human health and the environment.

Alternative 4 does not satisfy the statutory preference for treatment as a principal element of remediation, and there would be no reduction in toxicity, mobility, or volume of the contaminated groundwater through treatment. Residual contamination would remain high over many years, but, as for the other alternatives, contamination would not be expected to migrate substantially toward the production wells within 100 years.

\subsubsection{Implementability}

Slurry walls are widely used in remediation activities at other sites, but a number of implementability concerns would be posed by Alternative 4 at the QROU. Some difficulties associated with trench construction would be similar to those discussed for Alternative 3 (Section 3.4.3.2). 
One potential concern is the uncertainty of the long-term performance of physical barriers. For example, the slurry wall could potentially degrade or deteriorate with time. Another potential concern is the ability of containment structures to key in to the confining layers below the aquifer without creating leaks in the formation. To maintain the integrity of the barrier, the layer underlying the aquifer must be reasonably free of flow channels (National Research Council 1994). The top of the bedrock in the area of the slough is fractured, which would make keying in of the slurry wall difficult because of the uneven surface. The proximity of the slough would make construction of the slurry wall extremely difficult. The implementability of Alternative 4 would depend on the subsurface media conditions, and the final detailed design might have to be more conservative than that presented in Section 3.2.2.4 to compensate for the uncertainties associated with current knowledge concerning those conditions.

Groundwater monitoring would be required to track the progress and effectiveness of the containment walls. Active response measures (such as extraction with treatment at locations south of Femme Osage Slough) might be considered if future migration of residual contamination resulted in unacceptable exposure concentrations due to failure of the containment system.

Construction of a soil-bentonite slurry wall would be relatively straightforward; the type of equipment used would depend largely on the depth of the wall. No special equipment would be required for depths of up to $15 \mathrm{~m}(50 \mathrm{ft})$. Specialists might, however, be needed to implement this alternative. Although slurry walls have been used for decades, the process of designing the proper mix of wall materials to contain specific contaminants is less well developed. Excavation and backfilling of the trench would be critical and would require experienced contractors (Marks et al. 1994).

Resources required for maintenance and monitoring should be readily available. As a passive barrier, a slurry wall would require very little maintenance. The only requirement specific to the wall itself would be maintenance of the cap at the top of the wall.

Implementation of Alternative 4 might require obtaining new permits or licenses for on-site activities from the Missouri Department of Natural Resources or Conservation for use of their land. Transport of excavated solids from the site to the chemical plant area would require a short haul distance on Katy Trail. An access agreement between DOE and the Missouri Department of Natural Resources would be needed for use of this trail.

\subsubsection{Cost}

The estimated cost of Alternative 4 is between the costs for Alternatives 2 and 3. On the basis of the preconceptual design and application of cost factors specific to the Weldon Spring site 
for indirect activities (Hood 1997), the capital cost of Alternative 4 is estimated to be about $\$ 2$ million (Appendix E). The capital cost would be primarily for installation of the slurry wall.

The O\&M costs are estimated to be about $\$ 0.6$ million per year. The annual O\&M costs would be primarily for groundwater monitoring. However, higher O\&M costs would be incurred if it became necessary to provide hydraulic relief of groundwater buildup on the upgradient side of the barrier. Assuming a discount rate of $7 \%$ per year, the 30 -year present worth of Alternative 4 is estimated to be approximately $\$ 9$ million, which is considerably less than that for Alternatives 3 and 5.

\subsubsection{Alternative 5: In-Situ Treatment Using Permeable Barriers}

Alternative 5 would involve in-situ treatment of contaminated groundwater using a permeable barrier. Use of this barrier would be coupled with the installation of monitoring wells within the treatment media to track the sorption of uranium onto the clinoptilolite. Alternative 5 is described in Section 3.2.2.5.

\subsubsection{Effectiveness}

Alternative 5 would protect human health and the environment by remediating the contaminated groundwater so that when the remediation was complete, the uranium concentration in the groundwater within the quarry area and the land north of the slough would be below $30 \mathrm{pCi} / \mathrm{L}$. In addition, contaminant migration south of the slough would be largely halted, and any potential future large-scale contamination of the St. Charles County well field would be effectively prevented. Alternative 5 would be expected to attain all contaminant-specific and action-specific ARARs when remediation was complete.

Alternative 5 would reduce the volume of contaminants through treatment and would afford long-term protection. To maintain the effectiveness of this alternative, a long-term action involving excavation and removal of the spent treatment media would be required after the remediation was completed.

The short-term impacts of Alternative 5 would include those associated with the physical hazards to workers during construction of the permeable barrier system and operation of the monitoring system. Other short-term impacts would include criteria pollutant emissions resulting from construction activities and airborne dust emissions resulting from soil disturbance during site clearing, trench excavation, and regrading. Appropriate mitigative measures would be enacted during construction and operations to protect workers and members of the general public. Engineering controls, such as spraying water for dust suppression, would be used to minimize short-term risks 
to the public, and air monitoring would be used to ensure that the controls were working. Protective equipment would be used for workers, and dust suppression methods would be enacted to minimize short-term risks. The short-term impacts of Alternative 5 would be similar to those of Alternative 4 .

It is estimated that Alternative 5 would require up to 200 years or more of remediation to meet the metric of $30 \mathrm{pCi} / \mathrm{L}$ for uranium. Achieving acceptably low concentrations under this alternative might be precluded because of the uncertainty of the longevity and performance of the treatment media under actual operating conditions due to groundwater conditions that could cause plugging or fouling of the treatment media, thus rendering the media ineffective.

\subsubsection{Implementability}

Alternative 5 poses a number of implementability concerns, including a major issue associated with the lack of full-scale implementation for in-situ treatment of uranium using permeable barriers. Eight lab-scale and pilot-scale studies have been identified for in-situ treatment of uranium (Horstmann 1997) on the basis of data collected by the Groundwater Remediation Technologies Analysis Center. The technical immaturity of this technology raises questions regarding the implementability of Alternative 5.

Similar difficulties exist with trench construction under Alternative 5, as discussed for Alternative 3. Another potential concern is the ability of containment features to key in to the confining layers below the aquifer without creating leaks, because the bedrock in the area of the slough is fractured and has an uneven surface. Also of potential concern is the uncertainty of the long-term performance of permeable barriers, primarily because groundwater conditions such as biological activity at any given site could cause plugging or fouling of the media, thereby affecting the useful life of the treatment media.

The site hydrology and groundwater contaminants could lead to premature exhaustion of the treatment media before the contaminant plume was fully remediated. (Studies have demonstrated that the presence of common groundwater cations, such as calcium and magnesium, can reduce the absorption capacity of clinoptilolite [Freeman et al. 1986].) In such a case, the spent media would have to be excavated and replaced. The long-term effectiveness of Alternative 5 would depend in large part on subsurface media conditions. The final detailed design might have to be more conservative than that presented in Section 3.2.2.5 to compensate for the uncertainties associated with these conditions.

The adsorption reaction between uranium and clinoptilolite that takes place in the groundwater depends on several parameters, including $\mathrm{pH}$, oxidative/reduction potential, concentration of other contaminants that may prematurely degrade the clinoptilolite, and kinetics. 
Treatability studies using site-specific data would be necessary to determine the potential for successful application of this alternative.

Construction of a permeable barrier would be a relatively straightforward process; the type

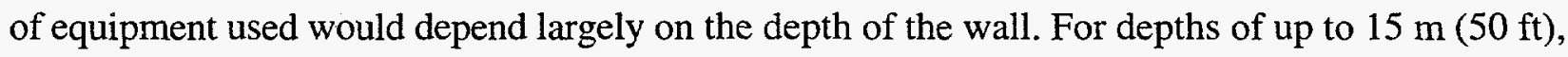
no special equipment would be required. However, specialists might be required to determine the proper mix of wall materials for containment of specific contaminants. Excavation and backfilling of the trench would be critical and would require experienced contractors (Marks et al. 1994).

Resources required for maintenance and monitoring should be readily available. As a passive treatment measure, a permeable barrier would require very little maintenance. The only specific requirement associated with the barrier would be maintenance of the groundwater monitoring wells.

Implementation of Alternative 5 might require obtaining new permits or licenses for on-site activities from the Missouri Department of Natural Resources or Conservation for use of their land. Transport of excavated solids from the site to the chemical plant area would require a short haul distance on Katy Trail. This activity would necessitate an access agreement between DOE and the Missouri Department of Natural Resources.

\subsubsection{Cost}

The estimated cost of Alternative 5 is comparable with that of Alternative 4 . Because of lower O\&M costs, in-situ treatment using permeable barriers has been reported to offer cost savings compared with active groundwater remediation techniques such as conventional pump-and-treat systems (DOE 1994a). On the basis of this preconceptual design and application of cost factors specific to the Weldon Spring site for indirect activities (Hood 1997), the capital cost of Alternative 5 is estimated to be about $\$ 8.5$ million (Appendix E). The capital cost would be primarily for installation of the permeable barrier.

The O\&M costs are estimated to be about $\$ 0.7$ million per year, primarily for groundwater monitoring. Assuming a discount rate of $7 \%$ per year, the 30-year present worth of Alternative 5 is estimated to be $\$ 21$ million, which is significantly more than the estimated cost for Alternative 4 and comparable to that for Alternative 3.

\subsubsection{Alternative 6: Groundwater Removal at Selected Areas, with On-Site Treatment}

Alternative 6 would involve extracting the quarry groundwater from selected areas in the aquifer (areas of localized high contaminant levels) using an interceptor trench and treating the 
extracted groundwater on-site at either the existing QWTP or a portable treatment facility (see: Section 3.2.2.6).

\subsubsection{Effectiveness}

Alternative 6 would result in a reduction of the mass of uranium that could potentially migrate to the downgradient St. Charles County well field. Alternative 6 would reduce the volume: of contaminants through treatment and be protective of human health and the environment over the: long term. Unlike Alternative 1, monitoring and investigative activities by DOE under Alternative 6 would enable the identification of any potential future plume migration and any variations in local geochemical conditions (such as Eh and $\mathrm{pH}$ ) that could adversely affect removal of the contaminants: from the groundwater by precipitation, biodegradation, and other natural means after the conclusion. of groundwater extraction and treatment. Such activities would ensure that the remediation goals of providing further protection of the St. Charles County well field were met and that the contaminant. distribution in the water-bearing zone was tracked. Contingency measures described in the Well' Field Contingency Plan (DOE 1998c) would be considered if data indicate that potential unacceptable exposure concentrations would appear at the St. Charles County well field. Unacceptable impacts to human health and the environment would not be expected to occur, on the basis of indications from monitoring data obtained for the last 10 years (see Section 1.4).

The potential short-term impacts associated with Alternative 6 would include the physical hazards to workers during construction of the interceptor trench and associated facilities (e.g., the pipeline connecting the interceptor trench with the QWTP) and during operation of the extraction and treatment systems. Other potential short-term impacts would be associated with criteria pollutant emissions (e.g., $\mathrm{CO}, \mathrm{NO}_{\mathrm{x}}$, and $\mathrm{SO}_{\mathrm{x}}$ ) resulting from construction activities and airborne dust emissions resulting from soil disturbance during site clearing, trench excavation, and regrading. Appropriate mitigative measures would be taken during construction and operations to protect workers and members of the general public. Engineering controls, such as spraying water for dust suppression, would be used to minimize short-term risks to the public, and air monitoring would be used to ensure that the controls were working. Protective equipment would be used for workers, and dust suppression methods would be enacted to minimize short-term risks. Fewer short-term impacts would result from Alternative 6 than from Alternative 3.

For Alternative 6 to remain effective over the long term, careful consideration would have to be given to monitoring, maintenance, and control. A time frame of about 100 to 1,000 years would be expected for the uranium concentrations to decrease to $30 \mathrm{pCi} / \mathrm{L}$ and lower, primarily because of the natural processes that are expected to occur. This alternative would result in contamination remaining in the groundwater at concentrations above levels that allow for unlimited use and unrestricted exposure. Consequently, a review would have to be conducted at least every five years 
to ensure that the remedy continued to provide adequate protection of human health and the environment.

Alternative 6 satisfies the statutory preference for treatment as a principal element of remediation, since there would be a reduction in the toxicity, mobility, or volume of the contaminated groundwater through treatment. Areas of high residual contamination would be remediated under Alternative 6 . The concentrations of contaminants in the area of the quarry would be expected to decrease with time because of the removal of the original source of contamination (i.e., the bulk waste) from the quarry, the planned quarry restoration activity (which is expected to prevent further infiltration of uranium present in the quarry fissures), and because of attenuation of uranium by sorption and redox mechanisms north of the slough and dilution with water infiltrating from the Missouri River within the coarse-grained materials south of the slough.

The uncertainty of the projected geochemical properties of the contaminants within the groundwater system might, however, preclude being able to adequately extract the contaminants and to attain lower concentrations. (The collection of water samples in certain areas of the quarry alluvial aquifer north of the Femme Osage Slough has required a period of several days to collect only as much as one liter of groundwater.) Performance data during the extraction and treatment phases would be used to assess the likelihood of restoring groundwater to established cleanup levels (i.e., the restoration potential).

\subsubsection{Implementability}

Similar difficulties exist with trench construction under Alternative 6 as discussed for Alternative 3. Another potential concern is the ability of containment features to key in to the confining layers below the aquifer without creating leaks, because the bedrock in the area of the slough is fractured and has an uneven surface.

No major difficulties would be anticipated for maintenance of the groundwater extraction system or use of the portable units for groundwater treatment. The groundwater treatment technologies identified in Section 3.2.2.6 are generally able to treat a wide range of contaminant concentrations, are available in off-the-shelf versions (i.e., require only a short lead time for procurement), have a short on-site startup time, are relatively simple to operate, and are available in easily transportable units (EPA 1996b). Portable units for groundwater treatment are generally available for flow rates between approximately $0.1 \mathrm{~L} / \mathrm{s}(1 \mathrm{gpm})$ and $160 \mathrm{~L} / \mathrm{s}(2,500 \mathrm{gpm})$, which encompass the proposed groundwater treatment rate of 0.6 to $1.3 \mathrm{~L} / \mathrm{s}(10$ to $20 \mathrm{gpm})$. A $4-$ to $5-\mathrm{L} / \mathrm{s}$ (60- to 75-gpm) mobile water treatment plant was operated by the DOE during the 1990s for wastewater treatment in the Uranium Mill Tailings Remedial Action (UMTRA) surface remediation program (DOE 1992). Similar units are available from commercial vendors. 
Groundwater monitoring would be required to track the progress and effectiveness of the groundwater remediation program. Monitoring the treated groundwater prior to its release to the Missouri River would also be required to ensure compliance with discharge limits in the existing NPDES permit.

In general, no special equipment would be needed to implement Alternative 6. Use of equipment for single-pass trench construction may, however, be considered because of the potential for cost and time savings. Resources should be readily available for groundwater monitoring and for maintenance of groundwater pumps and associated controls. The interceptor trench technology can be considered to be a proven technology (Wagner et al. 1986). However, because of the underlying; lithology at the site, detailed studies might have to be conducted to determine whether the interceptor trench system could be constructed as proposed in this alternative. Determining the required location. for an interceptor trench is more often based on the use of field data than on theoretical design. To function properly, an interceptor trench should be installed perpendicular to groundwater flow direction. Additional subsurface studies (borings) may be required to determine the proper orientation of the trench.

Treatability studies may be needed to accurately predict the site-specific effectiveness and total cost of filtration, ion exchange, precipitation, filter pressing, and other water treatment processes. Three tiers of testing may be undertaken (laboratory screening, bench-scale testing, and pilot-scale testing), depending on whether the QWTP would be used for groundwater treatment. If a portable unit becomes necessary, these studies may be needed during the remedial design phase to aid in the design or implementation of this alternative. Such studies would also be helpful in selecting among the various groundwater treatment technologies and improving remedy perforrnance (EPA 1997).

A major implementability concern for Alternative 6 is the active life of the QWTP and the portable treatment unit. The design life of the QWTP is 10 years (from FY 1992 to 2002). In FY 2002, extensive maintenance will be required in order to continue service beyond the design life (Valett 1997). The operating life of a typical portable wastewater treatment system can range from 5 (Shropshire et al. 1995) to 35 (DOE 1992) years, depending on the type of operation (batch versus continuous) and aggressiveness of treatment (service life is longer for less complex treatment technologies such as filtration). Groundwater treatment using the QWTP past FY 2002 may not be economical and may require replacement of the entire facility.

A second major implementability concern is the potential impact of the QWTP on the proposed Quarry Restoration Project. Current site plans call for the immediate decontamination and decommissioning (D\&D) of the QWTP to allow reconstruction of the quarry area. Operation of the QWTP to treat groundwater extracted from the quarry alluvial aquifer may negatively impact restoration of the quarry proper. 
Another major implementability concern is the possibility of flooding. The land between the quarry and the slough is subject to annual flooding; floods have occurred during the last three years. The design for any aboveground equipment would have to consider hardening the facility or possibly the entire quarry area against the effects of floods so that the chance of damage and interruption of operations would be acceptably low. Installation of temporary flood barriers, removal of equipment to protected areas, anchoring of vulnerable items, or installation of sumps or emergency pumps might be needed to mitigate the potential damage to mission-dependent components and systems.

New permits or licenses for on-site activities might be required to implement Alternative 6 . State and/or federal permits may be required for an off-site contractor to bring its portable treatment unit to the Weldon Spring site. License acquisition (for temporary possession of the uranium removed in the portable treatment unit) may be required by the off-site contractor to implement this alternative.

Another potential concern is the off-site transport of any contaminated wastes that could be generated after the closure of the on-site engineered disposal facility. The amount of waste generated by groundwater treatment that would require shipment to an off-site disposal facility is not very large and is equivalent to less than one truck shipment annually, on the basis of a net payload of $19,504 \mathrm{~kg}(43,000 \mathrm{lb})$. Shipping of low-level waste from the Weldon Spring site to an off-site disposal facility could involve numerous requirements under EPA and U.S. Department of Transportation (DOT) regulations and DOE Orders. Compliance activities would involve obtaining permits and/or notification of pertinent state agencies concerning hauling routes and transport schedules.

Another potential implementability concern is the proposed location for the interceptor trench. For this analysis, it was assumed to be situated north of Femme Osage Slough on land located in the Weldon Spring Conservation Area. The land near the slough is administered by the Missouri Departments of Conservation and Natural Resources; permission from these two agencies would be required before Alternative 6 could be implemented. Consideration of a portable groundwater treatment unit may require locating the units on land near the slough.

A final implementability concern is the final decontamination of the portable treatment unit after groundwater treatment is complete. If an acceptable level for off-site release is not achieved during decontamination, then the equipment may have to be purchased by DOE and then disposed of.

\subsubsection{Cost}

The estimated cost of Alternative 6 is between the costs for Alternatives 2 and 3. On the basis of the preconceptual design and application of cost factors specific to the Weldon Spring site 
for indirect activities (Hood 1997), the capital cost of Alternative 6 is estimated to be between $\$ 1$ and \$2 million (Appendix E), depending on whether the QWTP and the lower-cost single-pass trench construction are used. The capital cost would be primarily for the installation of the interceptor trench. The cost of the $1.3 \mathrm{~L} / \mathrm{s}(20 \mathrm{gpm})$ trailer-mounted water treatment unit was estimated to be approximately $\$ 0.6$ million, which is similar to the cost (\$0.6 million in $\$ 1990, \$ 0.8$ million in $\$ 1996)$ of the 4- to 5-L/s (60- to $75-\mathrm{gpm}$ ) mobile water treatment plant operated by DOE during the 1990s (DOE 1992).

The annual O\&M costs are estimated to be between $\$ 0.6$ million and $\$ 1$ million per year, depending upon the mode of treatment (QWTP versus portable units) and whether the costs of groundwater monitoring are included. The annual O\&M costs would be primarily for groundwater treatment (which ranges from $\$ 0.4$ to $\$ 0.5$ million per year). The unit cost of groundwater treatment was similar for both the QWTP and the portable units (at approximately $\$ 0.04$ per gallon), which is greater than the unit cost of $\$ 0.01$ to $\$ 0.02$ per gallon quoted in DOE (1992) for a $6.3-\mathrm{L} / \mathrm{s}$ (100-gpm) portable groundwater treatment unit. (The costing methodology applied in this analysis to estimate the annual operating cost for portable units predicted a unit cost of $\$ 0.015$ per gallon for a $6.3-\mathrm{L} / \mathrm{s}$ [100-gpm] portable system, similar to the unit cost provided in DOE [1992].)

Assuming a discount rate of $7 \%$ per year, five years of groundwater extraction and treatment, and neglecting the D\&D costs of the QWTP and the portable treatment units (which are highly speculative in the case of the portable unit), the 30-year present worth of Alternative 6 is estimated to range between $\$ 4$ million and $\$ 10$ million, which is less than that for Alternatives 3 and 5.

\subsection{SCREENING SUMMARY AND IDENTIFICATION OF FINAL ALTERNATIVES}

The results of the screening analysis for the preliminary alternatives are presented in Table 3.2. Each alternative was evaluated in accordance with the three criteria defined in the NCP: effectiveness, implementability, and cost. On the basis of the screening process, the following alternatives were excluded from further consideration:

- Alternative 3: Groundwater Removal with On-Site Treatment;

- Alternative 4: Containment; and

- Alternative 5: In-Situ Treatment Using Permeable Barriers.

Alternative 3 was not retained for further consideration because preliminary simulation results indicate that restoration time frames of at least 100 years would generally be necessary to restore the groundwater system using the interceptor trench technology (see Appendix B). This 
TABLE 3.2 Screening of Preliminary Alternatives

\begin{tabular}{|c|c|c|c|}
\hline Alternative & Effectiveness & Implementability & Cost \\
\hline $\begin{array}{l}\text { Alternative 1: } \\
\text { No Action }\end{array}$ & $\begin{array}{l}\text { Would provide no protection of human } \\
\text { health or the environment other than that } \\
\text { provided by natural attenuation of the } \\
\text { contaminants in the groundwater north of } \\
\text { the slough. Risk to the off-site public would } \\
\text { be low, even if the contaminants reached } \\
\text { the St. Charles County well field. No } \\
\text { reduction in toxicity, mobility, or volume of } \\
\text { the contaminated groundwater would occur } \\
\text { because the groundwater would not be } \\
\text { treated. }\end{array}$ & $\begin{array}{l}\text { No implementability concerns would } \\
\text { exist because no action would be taken. } \\
\text { No technologies or management } \\
\text { strategies would be implemented, nor } \\
\text { would any permits, licenses, or approvals } \\
\text { associated with undertaking a remedial } \\
\text { action be needed. }\end{array}$ & $\begin{array}{l}\text { No net present worth, capital, or } \\
\text { annual O\&M costs would be incurred } \\
\text { because no activities would be } \\
\text { undertaken. }\end{array}$ \\
\hline $\begin{array}{l}\text { Alternative } 2 \text { : } \\
\text { Monitoring with No } \\
\text { Active Remediation }\end{array}$ & $\begin{array}{l}\text { As for Alternative } 1 \text {; however, monitoring } \\
\text { would allow consideration of active } \\
\text { response measures in the future. Potential } \\
\text { minor short-term impacts could be incurred } \\
\text { by workers (mainly associated with } \\
\text { monitoring). Time to achieve the } \\
\text { remediation goal of } 30 \mathrm{pCi} / \mathrm{L} \text { in the } \\
\text { groundwater would be up to at least } \\
100 \text { years. }\end{array}$ & $\begin{array}{l}\text { Few implementability concerns would } \\
\text { exist because limited actions would be } \\
\text { required. Monitoring of plume migration } \\
\text { would be easy to implement. Proposed } \\
\text { monitoring would identify potential } \\
\text { problems before significant exposure } \\
\text { occurred; considering additional actions } \\
\text { prior to significant exposure would be } \\
\text { easy to implement. No special equipment } \\
\text { or specialists would be required. } \\
\text { Resources required for maintenance of } \\
\text { monitoring wells should be readily } \\
\text { available. }\end{array}$ & $\begin{array}{l}\text { Capital expenditures, annual costs } \\
\text { (associated with monitoring activities), } \\
\text { and present-worth costs would be low. }\end{array}$ \\
\hline
\end{tabular}


TABLE 3.2 (Cont.)

\begin{tabular}{|c|c|c|c|}
\hline Alternative & Effectiveness & Implementability & Cost \\
\hline $\begin{array}{l}\text { Alternative 3: } \\
\text { Groundwater Removal, } \\
\text { with On-Site Treatment }\end{array}$ & $\begin{array}{l}\text { Would protect human health and the } \\
\text { environment by remediating contaminated } \\
\text { groundwater. Might be expected to attain all } \\
\text { contaminant-specific and action-specific } \\
\text { ARARs when remediation was complete. } \\
\text { Would reduce volume of contaminants } \\
\text { through treatment and afford long-term } \\
\text { protection. No long-term action would be } \\
\text { required after remediation was complete. } \\
\text { Potential short-term impacts would be } \\
\text { associated with the transport of groundwater } \\
\text { treatment residuals for on-site storage and } \\
\text { disposal (prior to closure of the on-site } \\
\text { disposal cell), potential transport of } \\
\text { groundwater treatment residuals for off-site } \\
\text { disposal, physical hazards to workers during } \\
\text { construction and operation, criteria pollutant } \\
\text { emissions resulting from construction } \\
\text { activities, and airborne dust emissions } \\
\text { resulting from soil disturbance. Time to } \\
\text { achieve the remediation goal of } 30 \text { pCi/L in } \\
\text { the groundwater would be up to at least } \\
100 \text { years. }\end{array}$ & $\begin{array}{l}\text { Implementability concerns would be } \\
\text { associated with trench construction. No } \\
\text { major difficulties would be anticipated in } \\
\text { maintaining the groundwater extraction } \\
\text { system or the existing QWTP. No special } \\
\text { equipment or specialists would be } \\
\text { required to implement this alternative. } \\
\text { Resources required for maintenance and } \\
\text { monitoring should be readily available. } \\
\text { Implementability concerns would be } \\
\text { associated with the active life of the } \\
\text { QWTP and the disposal of contaminated } \\
\text { wastes. }\end{array}$ & $\begin{array}{l}\text { Moderate capital expenditures would } \\
\text { be associated with construction of the } \\
\text { groundwater extraction system and } \\
\text { slurry wall. High annual costs would } \\
\text { be associated with QWTP operations } \\
\text { and replacement after } 10 \text { years. The } \\
30 \text {-year present-worth costs would be } \\
\text { high. }\end{array}$ \\
\hline
\end{tabular}


TABLE 3.2 (Cont.)

\begin{tabular}{|c|c|c|c|}
\hline Alternative & Effectiveness & Implementability & Cost \\
\hline $\begin{array}{l}\text { Alternative 4: } \\
\text { Containment }\end{array}$ & $\begin{array}{l}\text { Would provide reduction in human health } \\
\text { risk because it would result in decreased } \\
\text { spread of contaminants to potential } \\
\text { exposure points. Potential short-term } \\
\text { impacts would be associated with physical } \\
\text { hazards to workers during construction and } \\
\text { operations, criteria pollutant emissions } \\
\text { resulting from construction activities, and } \\
\text { airborne dust emissions resulting from soil } \\
\text { disturbance. Short-term impacts would be } \\
\text { expected to be less than those for } \\
\text { Alternative } 3 . \text { Residual contamination } \\
\text { would remain high for many years. }\end{array}$ & $\begin{array}{l}\text { Implementability issues would be similar } \\
\text { to those for Alternative } 3 \text {. Implementa- } \\
\text { bility concerns would be associated with } \\
\text { trench construction, including the } \\
\text { uncertainty of long-term performance of } \\
\text { physical barriers. Another potential } \\
\text { concern would be the ability of contain- } \\
\text { ment structures to key in to the confining } \\
\text { layers below the aquifer without creating } \\
\text { leaks in the formation. }\end{array}$ & $\begin{array}{l}\text { Low-to-moderate capital expenditures } \\
\text { would be associated with construction } \\
\text { of the containment barrier: Moderate } \\
\text { annual costs would be associated with } \\
\text { monitoring and periodic replacement } \\
\text { of the slurry wall. The } 30 \text {-year present- } \\
\text { worth costs would be moderate. }\end{array}$ \\
\hline $\begin{array}{l}\text { Alternative 5: } \\
\text { In-Situ Treatment Using } \\
\text { Permeable Barriers }\end{array}$ & $\begin{array}{l}\text { Would protect human health and the } \\
\text { environment by remediating contaminated } \\
\text { groundwater. Might be expected to attain all } \\
\text { contaminant-specific and action-specific } \\
\text { ARARs when remediation was complete. } \\
\text { Would reduce the volume of contaminants } \\
\text { through treatment and afford long-term } \\
\text { protection. No long-term action would be } \\
\text { required after remediation was complete. } \\
\text { Potential short-term impacts would be } \\
\text { associated with physical hazards to workers } \\
\text { during construction and operations, criteria } \\
\text { pollutant emissions resulting from construc- } \\
\text { tion activities, and airborne dust emissions } \\
\text { resulting from soil disturbance. Fewer short- } \\
\text { term impacts would be expected than from } \\
\text { Alternative } 3 \text {. Time to achieve the metric of } \\
30 \text { pCi/L in the groundwater would be up to } \\
\text { at least } 100 \text { years. }\end{array}$ & $\begin{array}{l}\text { Implementability would be less certain } \\
\text { than for Alternative } 3 \text {. Implementability } \\
\text { concerns would be associated with trench } \\
\text { construction, including the uncertain } \\
\text { long-term performance of permeable } \\
\text { barriers. Another potential concern would } \\
\text { be the ability of the containment features } \\
\text { to key in to the confining layers below the } \\
\text { aquifer without creating leaks in the } \\
\text { formation. Implementability concerns } \\
\text { would also be associated with the limited } \\
\text { number of full-scale applications of the } \\
\text { permeable barrier technology. }\end{array}$ & $\begin{array}{l}\text { High capital expenditures would be } \\
\text { associated with construction of the } \\
\text { permeable barrier. Moderate annual } \\
\text { costs would be associated with moni- } \\
\text { toring and periodic replacement of the } \\
\text { permeable barrier material. The } \\
30 \text {-year present-worth costs would be } \\
\text { high. }\end{array}$ \\
\hline
\end{tabular}




\section{TABLE 3.2 (Cont.)}

\begin{tabular}{|c|c|c|c|}
\hline Alternative & Effectiveness & Implementability & Cost \\
\hline $\begin{array}{l}\text { Alternative 6: } \\
\text { Groundwater Removal } \\
\text { at Selected Areas, } \\
\text { On-Site Treatment }\end{array}$ & $\begin{array}{l}\text { Would protect human health and the } \\
\text { environment by remediating contaminated } \\
\text { groundwater. Would reduce the volume of } \\
\text { contaminants through treatment and afford } \\
\text { long-term protection. Potential short-term } \\
\text { impacts would be associated with the } \\
\text { transport of groundwater treatment residuals } \\
\text { for on-site storage and disposal (prior to } \\
\text { closure of the on-site disposal cell), } \\
\text { potential transport of groundwater treatment } \\
\text { residuals for off-site disposal, physical } \\
\text { hazards to workers during construction and } \\
\text { operation, criteria pollutant emissions } \\
\text { resulting from construction activities, and } \\
\text { airborne dust emissions resulting from soil } \\
\text { disturbance. Time to achieve the metric of } \\
30 \text { pCi/L in the groundwater would be up to } \\
\text { at least } 100 \text { years. }\end{array}$ & $\begin{array}{l}\text { Implementability concerns would be } \\
\text { associated with trench construction. No } \\
\text { major difficulties would be anticipated in } \\
\text { maintaining the groundwater extraction } \\
\text { system or the existing QWTP. No special } \\
\text { equipment or specialists would be } \\
\text { required to implement this alternative. } \\
\text { Resources required for maintenance and } \\
\text { monitoring should be readily available. } \\
\text { Implementability concerns would be } \\
\text { associated with the active life of the } \\
\text { QWTP and the disposal of contaminated } \\
\text { wastes. }\end{array}$ & $\begin{array}{l}\text { Low-to-moderate capital expenditures } \\
\text { would be associated with construction } \\
\text { of the groundwater extraction system } \\
\text { and potential purchase of portable } \\
\text { groundwater treatment unit. Moderate } \\
\text { annual costs would be associated with } \\
\text { trench and treatment operations. The } \\
\text { 30-year present-worth costs would be } \\
\text { moderate. }\end{array}$ \\
\hline
\end{tabular}


projected remediation time frame, which is controlled by the low permeability and porosity of the groundwater system, would require water treatment capacity to extend well beyond the 10-year design life of the QWTP. Replacement plants would be required for many years into the future to satisfy long-term removal and treatment needs.

Alternative 4 was not retained because the contamination would be contained within the quarry area without subsequent treatment, and there would be the potential for lack of long-term protection because of uncertainties regarding the long-term performance of physical barriers, including the possibility of continuous replacement of the slurry wall. Failure of the wall could allow contaminant migration toward the St. Charles County well field, because the electrical double layer of bentonite might increase the oxidation state of the aquifer near the slough, resulting in potential solubilizing of precipitated uranium (Gleason et al. 1997).

Alternative 5 was not retained for further consideration because the technology is not mature; it might also be rejected for technical reasons during the remedial design phase. In addition, the long-term performance of permeable barriers is uncertain (which might lead to multiple replacements of the in-situ treatment media), and the projected restoration time frame could be as long as 200 years.

On the basis of the screening process, the following alternatives were retained for detailed evaluation:

- Alternative 1: No Action;

- Alternative 2: Monitoring with No Active Remediation; and

- Alternative 6: Groundwater Removal at Selected Areas, with On-Site Treatment.

These alternatives are discussed further in Chapters 4 and 5. 


\section{DETAILED ANALYSIS OF FINAL ALTERNATIVES}

Three remedial action alternatives to address quarry groundwater contamination were retained through the screening process presented in Chapter 3:

Alternative 1: No Action;

Alternative 2: Monitoring with No Active Remediation; and

Alternative 6: Groundwater Removal at Selected Areas, with On-Site Treatment.

These alternatives are described further in Sections 4.1 through 4.3. Engineering information and identification of any required equipment that would be representative of a final remedial design are provided for the purpose of comparing the feasibility of the alternatives and assessing potential impacts on human health and the environment. Actual equipment requirements and engineering procedures would be defined in the ROD or subsequent remedial design/remedial action (RD/RA) reports, as appropriate.

A detailed analysis of these three final alternatives consisted of an assessment of each alternative relative to the following nine evaluation criteria as specified in the NCP:

1. Overall protection of human health and the environment: addresses whether each alternative provides adequate protection of human health and the environment. Evaluation focuses on a specific alternative's ability to achieve adequate protection and describes how site risks posed by each pathway are eliminated, reduced, or controlled through natural processes, treatment, engineering, or institutional controls. This evaluation also allows for consideration of any unacceptable short-term impacts associated with each alternative. Because of its broad scope, this criterion also reflects the focus of criteria 2 through 5 .

2. Compliance with ARARs: addresses whether all applicable or relevant and appropriate state and federal laws and regulations are met. Evaluation focuses on whether each alternative will meet federal and state ARARs and TBCs or whether there is justification for an ARAR waiver. Various ARARs and the waiver conditions are identified in Appendix A; key requirements for each alternative are discussed.

3. Long-term effectiveness and permanence: addresses the risk remaining at the operable unit after remediation goals have been met. Evaluation focuses on the 
ability of an alternative to maintain reliable protection of human health and the environment over time, once these goals have been met.

4. Reduction of toxicity, mobility, or volume: addresses the statutory preference for selecting alternatives that permanently and significantly reduce the toxicity, mobility, or volume of hazardous substances at a site. Evaluation focuses on the extent to which this is achieved by each alternative.

5. Short-term effectiveness: addresses the potential impacts to workers, the general public, and the environment during implementation of each alternative.

6. Implementability: addresses technical and administrative feasibility, including the availability and reliability of resources or materials required during implementation and the need to coordinate with other agencies.

7. Cost: addresses both capital costs and annual O\&M costs, as well as the combined net present worth, for each alternative.

8. State acceptance: addresses the statutory requirements for substantial and meaningful state involvement. Evaluation of this criterion will be addressed in the responsiveness summary and ROD that will be prepared following the public comment period.

9. Community acceptance: assesses the community's apparent preference for, or concerns about, the alternatives being considered. Evaluation of this criterion will be addressed in the responsiveness summary and ROD that will be prepared following the public comment period.

The effectiveness, implementability, and cost of the three alternatives retained for detailed analysis are summarized in Table 3.1. The three alternatives that were retained through the screening process were evaluated on the basis of criteria 1 through 7 relative to potential health and environmental impacts. The results of this comprehensive analysis are presented in Sections 4.1 through 4.3.

\subsection{ALTERNATIVE 1: NO ACTION}

The No Action Alternative provides a baseline for comparison with the other alternatives being evaluated. Under this alternative, the quarry groundwater would remain "as is." No containment, removal, treatment, or other mitigating actions would be implemented. This alternative does not include groundwater monitoring by DOE or any active or passive institutional controls that 
may serve to reduce any potential for human exposure (e.g., physical barriers, deed restrictions). Under this alternative, it is assumed that all existing activities, including monitoring by DOE, would be discontinued.

\subsubsection{Overall Protection of Human Health and the Environment}

The No Action Alternative would be adequately protective of human health and the environment over the long term. Under current conditions, the groundwater north of the slough poses no imminent risk to human health at the St. Charles County well field or the environment south of the slough. Future conditions are expected to be similar to current conditions, if not better, because the source of contamination (i.e., bulk waste) has been removed. Natural processes currently occurring will continue to slowly decrease the uranium concentrations that exist in quarry groundwater north of the slough.

\subsubsection{Compliance with Potential ARARs}

Potential regulatory requirements that might be applicable or relevant and appropriate to the final remedial action alternatives are identified and evaluated in Appendix A. With no action, the metric of $30 \mathrm{pCi} / \mathrm{L}$ for uranium would not be met for a long period of time (i.e., $>200$ years). The $30 \mathrm{pCi} / \mathrm{L}$ standard was established by the EPA for inactive uranium processing sites (40 CFR192) and has been determined to be relevant but not appropriate for the remediation activity being considered for the quarry groundwater. For nitroaromatic compounds, current quarry groundwater concentrations in three wells marginally exceed the standard for 2,4-DNT. However, concentrations of uranium and nitroaromatic compounds in quarry groundwater will continue to decrease with time as a result of source (bulk waste) removal from the quarry proper, degradation of the nitroaromatic compounds, reduction of uranium to form insoluble compounds that precipitate from the groundwater, and dilution from infiltration of rainwater and runoff and from sporadic local flooding.

\subsubsection{Long-Term Effectiveness and Permanence}

Under current conditions, the contaminated groundwater north of the slough poses no imminent risk to the St. Charles County well field or the environment south of the slough. Although contaminant concentrations would not be measured in the future, on the basis of current conditions, it is expected that unacceptable impacts to human health and the environment would not occur. 


\subsubsection{Protection of Workers}

No activities are associated with the No Action Alternative, thus workers would not be exposed to hazardous substances. Consequently, there would be no risks to workers associated with this alternative.

\subsubsection{Protection of the Public}

Potential impacts to members of the general public on the basis of current conditions are summarized in Chapter 1. Estimated current risks are assumed to be representative of future risks because land uses and risk scenarios can be assumed to be similar. On the basis of these risk results, unacceptable risks to a member of the general public are not likely to occur under the No Action Alternative.

\subsubsection{Environmental Protection (Water Quality and Hydrology)}

The concentration of contaminants in the area of the quarry has decreased with time because the source of the contamination was removed from the quarry. Reduction of uranium near the slough with subsequent precipitation and dilution from infiltration of rainwater and runoff and from sporadic local flooding would also decrease the contaminant concentrations in the groundwater. Residual contamination from the quarry proper is prevented from migrating to areas south of the slough due to reduction and precipitation, dilution, and sorption (DOE 1998b). In the unlikely event that the uranium contamination did migrate south of the slough, calculations indicate that a uranium concentration of $21 \mathrm{pCi} / \mathrm{L}$ might be measured at a single county well south of the slough, assuming that the average uranium groundwater concentration would be $2,800 \mathrm{pCi} / \mathrm{L}$ north of the slough and that all uranium contamination would migrate to a single production well (DOE 1998b). The estimated uranium concentration of $21 \mathrm{pCi} / \mathrm{L}$ is below the metric of $30 \mathrm{pCi} / \mathrm{L}$.

\subsubsection{Reduction of Toxicity, Mobility, and Volume through Treatment}

Reduction of toxicity, mobility, and volume through treatment is not applicable to Alternative 1 because the contaminated groundwater would not be treated under this alternative.

\subsubsection{Short-Term Effectiveness}

No short-term impacts would occur to human health or the environment because no remedial action would be conducted. 


\subsubsection{Implementability}

No concerns regarding implementability are associated with Alternative 1 because no action would be taken nor would any future activities be considered. No technologies or management strategies would be implemented, nor would any permits, licenses, or approvals associated with undertaking a remedial action be needed.

\subsubsection{Cost}

No net present worth, capital, or annual O\&M costs are associated with the No Action Alternative because no activities would be undertaken.

\subsection{ALTERNATIVE 2: MONITORING WITH NO ACTIVE REMEDIATION}

Under Alternative 2, long-term monitoring of the groundwater would be performed. The contaminant concentration in the groundwater north of the slough would slowly decrease with time. This decrease could result from (1) attenuation of the uranium by sorption in the fine-grained alluvium of near-surface soil (which contains much humic material and iron-manganese hydroxide), and (2) precipitation of uranium out of solution in the area of the slough where decaying organic matter maintains a reducing condition. This process converts uranium to the +4 state, forming uranium dioxide $\left(\mathrm{UO}_{2}\right)$, which is highly insoluble and would precipitate out of solution. Sampling data from the monitoring wells south of the slough and from the county production wells indicate that uranium in the groundwater has not migrated to the St. Charles County well field. This may be due to reduction of the uranium to insoluble compounds that rapidly precipitate from groundwater (DOE 1998b). If, although unlikely, the contaminated groundwater from the quarry area did migrate south of the slough, the contaminant concentrations would be significantly decreased by dispersion and dilution with uncontaminated groundwater drawn from the Missouri River underflow and by dilution from infiltration of rainwater and runoff and from sporadic local flooding.

Groundwater monitoring would be conducted using the existing well network, as appropriate. This network could be expanded or reduced, depending on the results of future efforts to optimize the network for long-term monitoring. For conservatism, the evaluation of Altemative 2 for this assessment assumed the construction and operation of additional monitoring wells equivalent to approximately $15 \%$ of the number of existing wells (i.e., about seven additional wells). The exact monitoring network and details regarding frequency of sampling and parameters analyzed will be identified in the ROD or subsequent RD/RA reports for this operable unit. The current groundwater monitoring program for the quarry area consists of 45 DOE monitoring wells, 4 monitoring wells owned by St. Charles County, and 8 municipal production wells. Of these wells, 19 monitor groundwater in the bedrock system (Kimmswick Limestone, Decorah Formation, or Plattin 
Limestone). The remaining wells and all county-owned monitoring and production wells are screened in the alluvium (information on well locations and depths is provided in DOE [1998a]).

The monitoring program would continue for a period of time specified in the ROD. Standard operating procedures used for current monitoring activities would be expected to be adopted for the long-term monitoring effort. Water levels would be measured during each sampling, event. Quality assurance/quality control samples would be collected during each sampling event.

The monitoring frequency for the wells is expected to be location-specific, depending on the level of contamination encountered. For example, wells with low concentrations of contaminants that are constant over time would be sampled less frequently than wells with uranium concentrations much greater than $30 \mathrm{pCi} / \mathrm{L}$. For this analysis, it was assumed that the frequency of sampling would be seasonal (quarterly), although a semiannual monitoring frequency might be possible because of the low groundwater velocities. Details of this monitoring will be presented in subsequent reports prepared for this operable unit, as appropriate.

Periodic maintenance of the groundwater monitoring wells and dedicated sampling equipment would be expected to extend the life of the equipment. Monitoring wells would be evaluated with regard to performance and condition and integrity of various well components such as concrete pads, posts, and protective casings. Periodic inspections to determine the need for maintenance would be guided by the collection and analysis of representative groundwater samples. After the completion of long-term monitoring activities, the monitoring wells would be managed in accordance with on-site procedures (e.g., plugged and abandoned).

Because contamination would remain on-site at concentrations above levels that allow for unlimited use and unrestricted exposure, reviews would be conducted at least every five years to ensure that the remedy continued to provide adequate protection of human health and the environment.

\subsubsection{Overall Protection of Human Health and the Environment}

Alternative 2 would be adequately protective of human health and the environment over the long term. Under current conditions, the groundwater north of the slough poses no imminent risk to human health at the St. Charles County well field or the environment south of the slough. Potential further migration of the contamination toward the production wells would be monitored. Investigative activities would enable identification of continued plume migration and any variations in local geochemical conditions (e.g., Eh, $\mathrm{pH}$ ). These variations could adversely affect removal of the contaminants from the groundwater by natural processes such as absorption, adsorption, precipitation, and biodegradation. This monitoring program would be used to measure the attainment of remediation goals, that is, a further reduction of uranium concentrations or mass in quarry 
groundwater to lower the amount that could potentially migrate to the well field. Contingency measures, as provided for in the Well Field Contingency Plan (DOE 1998c), would be implemented to prevent unacceptable exposure concentrations at the St. Charles County well field. Contaminant reduction north of the slough would be the result of natural processes, including dilution.

\subsubsection{Compliance with Potential ARARs}

Compliance with potential ARARs for this alternative would be the same as for Alternative 1 (Section 4.1.2).

\subsubsection{Long-Term Effectiveness and Permanence}

Under current conditions, the contaminated groundwater north of the slough poses no imminent risk to the St. Charles County well field or the environment south of the slough. Monitoring and maintenance activities would be carried out by DOE for a period of time specified in the ROD. Protection of human health and the environment in the extended future would be ensured, because investigative and monitoring activities by DOE would continue and allow consideration of active response measures if future migration of residual contamination resulted in unacceptable exposure concentrations at the well field. However, unacceptable impacts to human health and the environment are not expected to occur.

\subsubsection{Protection of Workers}

Long-term monitoring and maintenance activities would be carried out for a period of time specified in the ROD. Workers would be present on-site periodically to perform these activities. The potential impact on sampling personnel from exposure to contaminants would be low.

Monitoring activities over a 30-year period are estimated to result in approximately eight cases of occupational injury and no occupational fatalities (Appendix D); these estimates are based on industry-specific statistics from the U.S. Bureau of Labor Statistics, as reported by the National Safety Council (1995). Alternative 2 would, therefore, pose low long-term risks to workers.

\subsubsection{Protection of the Public}

Similar to the No Action Alternative, unacceptable risks to the general public would not be expected to occur under Alternative 2, even if conditions would remain as they are currently. 
However, with monitoring, information on future concentrations of contaminants in groundwater would be available to confirm this expectation.

\subsubsection{Environmental Protection (Water Quality and Hydrology)}

Water quality and hydrology would be the same for Alternative 2 as for Alternative 1.

\subsubsection{Reduction of Toxicity, Mobility, or Volume through Treatment}

Reduction of toxicity, mobility, or volume through treatment is not applicable to Alternative 2 because contaminated groundwater would not be treated under this alternative.

\subsubsection{Short-Term Effectiveness}

Construction activities are estimated to result in less than one case of occupational injury and no occupational fatalities (Appendix D). This estimate is based on industry-specific statistics from the U.S. Bureau of Labor Statistics, as reported by the National Safety Council (1995).

Some short-term impacts on recreational use of the surrounding wildlife areas might occur as a result of noise, exhaust fumes, and dust associated with any construction of new monitoring wells. Impacts to biological resources would be mitigated by avoiding unnecessary damage to vegetation, wildlife, and soil through controlling traffic and minimizing the areas of disturbance.

During construction of the additional monitoring wells, the amount of criteria pollutants emitted as a result of equipment operations and transportation (by car) of the construction personnel to the quarry area would be low (e.g., less than $380 \mathrm{~kg}$ [840 lb] of CO emitted during the entire construction period [Appendix D]), and as such, would not contribute to any off-site health impacts. Assuming a total of 52 DOE monitoring wells (45 existing, 7 assumed new), a quarterly sampling frequency, a mobilization distance of $8 \mathrm{~km}(5 \mathrm{mi})$, and (conservatively) only one well sampled pe: trip, the annual emission rate of criteria pollutants from worker vehicles would be low (e.g., less thar! $45 \mathrm{~kg}$ [100 lb] per year of carbon monoxide emitted [Appendix D]) and would not contribute to any' off-site health impacts. Emissions of total suspended particulates (TSP) were estimated to be: approximately $2,700 \mathrm{~kg}(5,900 \mathrm{lb})$, assuming that all vehicles traveled over unpaved roads withoul: any control measures. Vehicle traffic on unpaved surfaces would be the major source of TSP. TSF generation during actual construction activities would be suppressed by watering, revegetation of: bare areas, removal of dirt and debris from the road surface, and the use of containment methods whenever feasible. These temporary impacts would be limited to the immediate vicinity of the quarry area; mitigative measures would be applied to ensure minimal impacts to off-site areas. 


\subsubsection{Implementability}

Few implementability concerns would be posed by Alternative 2 because of the limited actions taken. Site operations would continue to use readily available resources for monitoring. Construction of any new monitoring wells would simply require mobilization of a drilling rig for installation. Minimal administrative complexities, including permit applications, would be associated with monitoring well installation.

Groundwater monitoring could be readily implemented. Numerous wells currently exist at the quarry area, and additional wells could be easily installed and monitored. Monitoring of plume migration would be relatively easy to implement. The results from sampling of the existing network of monitoring wells would be used to identify the potential for significant exposure before it occurred at the well field. Therefore, taking additional actions prior to significant exposure at the well field would be relatively easy.

The administrative feasibility of Alternative 2 would be relatively straightforward. Remedial activities at the Weldon Spring site are coordinated with the State of Missouri and EPA Region VII. That coordination would continue during the implementation of Alternative 2, and no additional coordination would be required with any other agencies beyond that already occurring. No permits or licenses would be required for on-site activities.

\subsubsection{Cost}

Costs for this alternative would be associated with continuing the existing environmental monitoring program, constructing and operating possible new monitoring wells, and conducting a performance review at least every five years. Feasibility-level cost estimates were prepared using standard cost-estimating sources. The proposed monitoring wells were assumed to be constructed of stainless steel for long-term effectiveness. It was conservatively assumed in this analysis that the new wells would be purged and sampled with dedicated pumps.

The costs for individual construction activities were taken from the latest version of the Unit Price Book developed by the U.S. Army Corps of Engineers (1989). A cost differential was included to account for the differences in material and labor costs for the Weldon Spring site compared with the generic Unit Price Book costs. The workforce estimates for various support activities (e.g., construction and health and safety plan) were derived by a parametric approach based upon similar levels of construction activities for related construction projects. Miscellaneous costs - such as those for small tools, indirect costs, and bond and insurance costs - were estimated on the basis of various percentages of other costs (Hood 1997). Present worth was calculated from procedures identified in EPA guidance and by using a $7 \%$ discount rate (before taxes and after 
inflation [EPA 1993b]). Long-term maintenance costs were based on a 30-year period, in accordance with EPA (1988a) guidance, and include annual sampling and analytical costs.

The estimated total and present-worth costs for Alternative 2 are given in Table 4.1; annual costs are estimated to be approximately $\$ 0.6$ million.

The costs associated with potential future actions, in the event that potential migration of residual contamination did result in unacceptable exposure concentrations, were not quantified because the uncertainty associated with these future activities precludes accurate assessment of these costs.

\subsection{ALTERNATIVE 6: GROUNDWATER REMOVAL AT SELECTED AREAS, WITH ON-SITE TREATMENT}

Under Alternative 6, an interceptor trench approximately 1-m (3-ft) wide and about 5-m (16-ft) deep would be installed north of the Femme Osage Slough in a selected area bounded by and

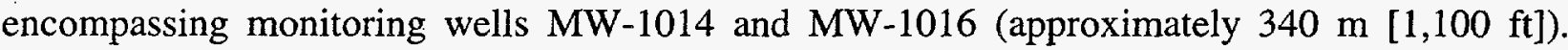
Interceptor trench systems are generally used in groundwater recovery systems if the water table is fairly shallow and the soil is of low permeability. The purpose of the trench is to create a highpermeability channel through the native soil to recover more groundwater than a vertical extraction

TABLE 4.1 Cost Estimate for Alternative 2

\begin{tabular}{lc}
\hline \multicolumn{1}{c}{ Activity } & $\begin{array}{c}\text { Estimated Cost } \\
(\$ \text { million })\end{array}$ \\
\hline Ground monitoring well construction $^{\mathrm{a}}$ & 0.15 \\
Groundwater monitoring $^{\mathrm{b}}$ & 15.3 \\
Total $^{\mathrm{b}}$ & 15.5 \\
Present worth $^{\mathrm{b}}$ & 6.5 \\
\hline
\end{tabular}

a Based on construction of seven new wells.

b Estimated upper-bound cost for a 30-year period, assuming current sampling frequency for the existing network of monitoring wells. Any reduction in duration of monitoring, sampling frequency, or number of wells sampled would result in a proportional reduction in cost. 
well could. The saturated zone of the trench would be backfilled with a high-permeability material such as gravel. A perforated pipe would be installed horizontally in the base of the trench to conduct water to a series of underground sumps.

The major activities associated with trench construction are site preparation; trench excavation and stabilization; and installation of the underground sumps (drains) and fabric filter, drain pipe, and gravel material. An area of approximately 0.5 ha ( 1 acre) would initially be cleared of vegetation such as trees, shrubs, and brush; the stumps, roots, and debris would be removed from the soil by using dozers or other heavy equipment. About $2,100 \mathrm{~m}^{3}\left(2,800 \mathrm{yd}^{3}\right)$ of material would be excavated in the development of the trench. This analysis assumes that haul trucks with tarp covers securing the loads would be used to transport the excavated solids a total of approximately $6 \mathrm{~km}$ (4 mi) from the quarry to the chemical plant area at the Weldon Spring site for either direct placement in the WSSRAP on-site disposal cell or temporary stockpiling until placement could take place (Valett 1997). (These soils could also be used for backfill in the quarry, depending on the contaminant level.) On the basis of a truck capacity of about $15 \mathrm{~m}^{3}\left(20 \mathrm{yd}^{3}\right)$ and $50 \%$ fill, a total of 280 shipments would be required.

Excavation of an interceptor trench is usually a relatively straightforward process. For depths of up to $7.6 \mathrm{~m}(25 \mathrm{ft})$, no special equipment is required. This analysis assumes that an excavator would be used primarily to dig the trench and to load trucks. Excavators are typically used for trenching or borrow excavation on dry, stable ground such as that seen at the quarry area. Excavators are also used more commonly where the bucket does not have to reach to depths greater than those at the quarry area.

For this analysis, it was assumed that underflow underneath the interceptor trench would be minimized by installation of a barrier wall composed of 13-cm (5-in.) thick HDPE downgradient of the interceptor trench. The necessity for containment provided by the HDPE liner would be determined during the final design, at which time the proximity of the interceptor trench to the Femme Osage Slough, among other factors, would be taken into consideration. The interceptor trench would be keyed in to the lower permeability layer underlying the alluvial soils, assuming fragmentation of the rock using a backhoe-mounted pneumatically-driven impact tool such as an Ingersoll-Rand "Hobgoblin" (Richardson Engineering Services 1993). The impact tool would break up and loosen the rock or hard soil to a state where a Caterpillar 235 backhoe could remove the loosened material. Generally, rock that can be removed by this approach is well weathered, fractured, or fragmented; including most caliches and soft sedimentary rock (i.e., chalk and sandstone), glacial tills, and hard clays. Other methods may be necessary if this or a similar approach cannot be utilized at the quarry area.

Side wall protection would be provided during excavation. Pursuant to current OSHA

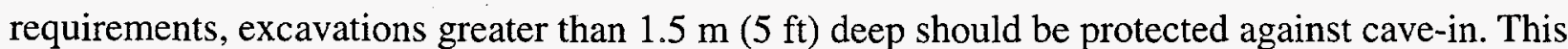
is normally accomplished either by installing sheeting, trench boxes, or by sloping the excavation 
walls. Trench boxes or sheeting are generally the best methods for interceptor trench installation; this analysis assumed side wall protection by trench boxes. (Side sloping for deeper trenches creates a larger area in which contaminated soil may spread and contaminate previously uncontaminated areas.)

Proper installation of the interceptor drain (i.e., maintenance of grade, placement, and alignment of pipes) would require dewatering to achieve a dry environment. (Although dewatering may not be necessary for extremely firm soils, or low yielding formations, this analysis conservatively assumed dewatering would be necessary. The requirement for dewatering would be examined during the final design, at which time the potential for precipitation during trench excavation would be taken into account.) Wellpoints would be used to lower the water table near the trench excavation and are one of the most widely used and most versatile dewatering technologies where total lift or Drayton will not exceed $6.7 \mathrm{~m}$ (22 ft) (Wagner et al. 1986). Wellpoint systems consist of a group of closely spaced wells connected to a header pipe and pumped by a suction pump. This analysis assumed that $69 \mathrm{~m}(225 \mathrm{ft})$ of header pipe with well points $1.5 \mathrm{~m}(5 \mathrm{ft})$ on center for each 500 linear meters (1,650 linear ft) of trench (Wong et al. 1997). The contaminated groundwater that is recovered during the dewatering process (on the order of 140,000 L [38,000 gal], based on a total of about $1,600 \mathrm{~m}^{3}\left[56,000 \mathrm{ft}^{3}\right]$ excavated and a backhoe excavation rate of $100 \mathrm{~m}^{3} / \mathrm{h}$ $\left[130 \mathrm{yd}^{3} / \mathrm{h}\right]$ ), would be either stored and then transported to the QWTP for treatment or treated by the mobile treatment unit prior to release to the Missouri River via the 10-cm (4-in.) QWTP pipeline.

Once trench excavation was completed, the components of the subsurface drain would be installed. This process includes installing the fabric filter, laying the pipes and gravel (envelope material), backfilling, and installation of auxiliary components. This analysis assumes that a fabric filter is first installed at the outer edges of the trench to prevent fines from clogging the gravel and drain pipe. Replacing the geotextile liner with a filter sock placed on the pipe or gradation of the gravel to prevent clogging may be considered in the final design. Well-graded gravel between 1.3 to $1.9 \mathrm{~cm}$ (1/2 to $3 / 4 \mathrm{in}$.) in size would be laid in an even layer to provide bedding for the drain pipes. Perforated PVC pipe with a nominal diameter of $0.15 \mathrm{~m}(0.5 \mathrm{ft})$ would be used to convey the groundwater to an underground wet well (sump). (The pipe diameter was estimated using the Manning equation [Wagner et al. 1986] to ensure that water that arrives at the drain pipe can be: conveyed without a buildup of pressure.) Additional gravel would be installed around the drain pipe; to increase flow into the interceptor trench and reduce the potential buildup of sediments in the drair. pipe. This analysis assumes that the gravel would be placed into the trench by a wheeled loader. The: fabric filter would then be wrapped around the top of the gravel prior to backfilling with soil.

This analysis assumes that the groundwater collected by the interceptor trench would discharge into a total of six underground sumps, on the basis of the methodology provided in the French Drain System for Site Remediation (Naval Energy and Environmental Support Activity 1991). The actual number of sumps would be determined during the final design, at which time the variation in the elevation of the top of the bedrock would be taken into account. Each sump is 
assumed to be $0.9 \mathrm{~m} \mathrm{(} 3 \mathrm{ft}$ ) in diameter and (conservatively) assumed to be constructed of reinforced concrete pipe. (The construction material for each sump would be determined in the final design; HDPE or other plastics may be used.) A single submersible pneumatically driven groundwater extraction pump would be installed inside each sump to deliver the extracted groundwater to a piping network that connects each sump to a manifold. From the manifold, a single pipeline would bring contaminated groundwater to a $30,000-\mathrm{L}(8,000$-gal) single-walled aboveground storage tank located on a $20-\mathrm{cm}$ (8-in.)-thick reinforced concrete pad with engineered berms for secondary containment. A double-wall PVC pipeline (diameters of about $10 \mathrm{~cm}$ and $15 \mathrm{~cm}$ [4 and $6 \mathrm{in}$.]) would be constructed to transfer the water from the interceptor trench storage tank for treatment (doublewalled construction is used to ensure leak protection).

The trench would be backfilled to the original grade. It is (conservatively) assumed that soil required from off-site to complete backfilling (approximately $90 \mathrm{~m}^{3}\left[120 \mathrm{yd}^{3}\right]$ ) would be normal construction quality soil borrowed less than $8 \mathrm{~km}(5 \mathrm{mi})$ from the site. To prevent settling of the backfill after trench construction, periodic compaction of the soil lifts using a vibrating plate compactor would be performed. Topsoil, subsoil, mulch, and seed would be added to restore ground cover.

Two options currently exist for treating the extracted groundwater: the existing QWTP or a portable unit. In the case in which the extracted groundwater would be treated at the existing QWTP, a double-wall pipeline would be constructed connecting the discharge of the interceptor trench with the QWTP. The following text describes a typical scenario for the potential use of the QWTP. (On the basis of the quarry restoration project, the QWTP could be modified and the equalization basin may not be available, in which case a tank would be used for storage prior to batch treatment at the QWTP). Groundwater would be pumped from the interceptor trench to the existing equalization basin at the QWTP. The existing water treatment system at the quarry consists of an equalization basin, a water treatment plant and two effluent ponds. The equalization basin serves as a reservoir to provide consistent flow and uniform contaminant concentration at the QWTP. The water then goes through six major steps - lime mix, clarification, multimedia filter, activated alumina, activated carbon, and ion exchange - aimed successively at the ever diminishing amount of chemicals and radioactive materials (see Section 3.2.2.3). The on-site QWTP would be operated on a campaign mode, that is, whenever the equalization basin would contain sufficient groundwater for continuous operation of the water treatment process. The extracted groundwater would be treated at the QWTP for a total of two years to establish the technical feasibility of this alternative. The proposed plan is to expand this duration if results are favorable. At the end of the two-year period, the QWTP would be decontaminated and dismantled; contaminated materials would be sent for permanent disposition at the WSSRAP on-site disposal cell.

Two effluent ponds, each with the capacity of 3.8 million liters (one million gallons), would collect the treated water from the QWTP until analysis would assure that the water is safe for discharge. Each batch of treated water would be chemically analyzed to confirm compliance with 
the requirements of the NPDES permit. While the first batch is tested, the second effluent pond would collect another batch of treated water. If the water does not meet NPDES standards, it would be treated again.

Portable treatment units would be used if the QWTP was unavailable. A trailer-mounted unit was assumed in this analysis to facilitate ease of transporting the unit to the area north of the Femme Osage Slough and to allow removal of the trailer-mounted system in the event of flooding of the Missouri River in the region of the quarry. Further information concerning the installation and O\&M activities of the portable treatment units is provided in Section 3.2.2.6.

The process flow diagram for the portable groundwater treatment system is shown in Figure 3.8. This system is described primarily for purposes of illustration to help the reader understand what would be involved in treating groundwater extracted from this operable unit using, a portable system); it is not intended as a final or definitive treatment system. Other treatment processes or system configurations could be used, provided they are capable of cost effectively achieving the required effluent concentrations.

Extracted groundwater would be sent to a feed tank. This tank would provide equalization of influent to dampen variations in flow and groundwater quality. The tank would also receive recycled water from dewatering (i.e, the filter press). A treatment system that does not have to deal with rapid and massive changes in feed is generally more efficient in its task, as well as considerably less expensive to design and build.

Sedimentation precipitation would be used to remove uranium and other metals. Several precipitation additives would be considered in a treatability study. Lime is the most common precipitant used, primarily because of its low cost. An additive (or combination of additives) would be selected on the basis of cost and the volume of sludge produced. Influent $\mathrm{pH}$ adjustment may not: be necessary, although it could easily be added to the system if necessary.

Clarifiers are generally sufficient for removing suspended solids. However, solids from precipitation sometimes coagulate and settle poorly, so that a clarifier might provide insufficient: removal. However, the clarifier overflow in this system passes through a series of multimedia filters. If the solids from precipitation coagulate and settle poorly, the filter columns would be sized to handle the additional solids loading.

Sludge from the clarifier, which contains the solids and precipitated uranium and othel metals, would be dewatered using a recessed plate (plate-and-frame) filter press. This type of filter press can usually achieve greater than $50 \%$ solids in the filter cake. The dewatered sludge would be: sent to the WSSRAP on-site disposal cell for ultimate disposition. Most of the solids in the sludge: would be normal (noncontaminant) dissolved solids, such as calcium carbonates and magnesium 
hydroxides (DOE 1998b). Radioactive contaminants would be present in relatively low concentrations.

Multimedia filtration would be used to remove suspended solids from the effluent of the neutralization process. Filtration would be needed to prevent fouling or plugging of the ion-exchange resin. Two columns in parallel would be used. One column would be on line, while the other column was being backflushed with treated groundwater.

The effluent from the multimedia filter would then pass through two ion-exchange columns in series. The system would include a third column, which would allow two-column operation while one column was being regenerated. The ion-exchange columns would be regenerated with acidic, basic, or salt solutions (depending on the resin used). For example, a solution of sodium chloride and soda ash is used for regeneration of ion-exchange systems used in mining uranium (DOE 1993a).

Series operation of the ion-exchange columns would allow maximum resin loading and provide a safety factor against off-specification effluent. Water quality would be monitored after the first column, as well as after the second. When breakthrough (rapidly rising contaminant concentrations) was observed in the first column, the third (fresh) column would be placed on line (third in series. This would allow the first column to be run to exhaustion without any danger of exceeding effluent specifications. When the first column was exhausted, it would be taken off line and regenerated. After regeneration, it would become the new third column. This operation would allow more efficient regeneration, which would lower costs. The third column would also provide a backup in the event that one column required maintenance.

The treated water would be collected in a surge tank to determine whether it is below the MCLs for the contaminants. If so, the treated water would be directed to the Missouri River via a buried gravity flow pipeline. It is assumed that the flow would be routed via the existing river outfall or a new outfall.

Treatability studies would be necessary to determine the site-specific effectiveness of filtration, ion exchange, precipitation, clarification, and filter pressing. This information would be used in the final design of the portable treatment unit.

Long-term monitoring of the groundwater would be conducted similar to that considered in Alternative 2 (see Section 4.2). The monitoring program would be carried out for a period of time specified in the ROD. Standard operating procedures used for the current monitoring and periodic maintenance activities would be expected to be adopted for the long-term effort. Work area monitors would be used during activities such as earthmoving to assure that radiation levels in the air are maintained within established limits. 
Because contaminants would remain on-site in the groundwater at concentrations above: levels that allow for unlimited use and unrestricted exposure, reviews would have to be conducted at least every five years to ensure that the remedy continued to provide adequate protection of human: health and the environment.

\subsubsection{Overall Protection of Human Health and the Environment}

Alternative 6 would be adequately protective of human health and the environment over the long term by removing groundwater from selected areas in the quarry alluvial aquifer (i.e., areas: of localized high contaminant levels) to reduce the potential for further migration of uranium south. of the Femme Osage Slough. Under current conditions, the groundwater north of the slough poses no imminent risk to human health at the St. Charles County well field or the environment south of the slough. Further degradation of the groundwater within the alluvial aquifer north of the Femme: Osage Slough would be reduced because of the reduction in the mass of uranium within the quarry aquifer. Similar to Alternative 2 (see Section 4.2.1), restoration of the water-bearing zone north of the slough would be provided by natural attenuation processes and dilution of the contaminated. groundwater with uncontaminated groundwater drawn from the Missouri River.

The extracted groundwater would be treated to remove uranium and other contaminants before being discharged to a permitted point. The uranium and other contaminants removed from. the groundwater would be stabilized as needed and placed in the WSSRAP on-site disposal cell (or a similar off-site facility), which is designed to prevent migration of contaminants from the cell to the environment.

Alternative 6 is not expected to result in any unacceptable impacts to human health or the environment during implementation; potential impacts are discussed in Sections 4.3.3 and 4.3.5.

\subsubsection{Compliance with Potential ARARs}

Compliance with potential ARARs for this alternative would be similar to Alternative 1 in that the metric of $30 \mathrm{pCi} / \mathrm{L}$ would not be met for a long period of time; however, action-specific ARARs primarily related to construction activities would be attained. Although it is estimated that under Alternative 6 up to $10 \%$ of the current mass of uranium in quarry groundwater could be extracted and treated in about a two-year period, it would still take more than 100 years for uranium concentrations in quarry groundwater to decrease to $30 \mathrm{pCi} / \mathrm{L}$ and below. Several existing conditions at the quarry area contribute to the slow reduction or removal of uranium from the system. These conditions are consistent with those considered to satisfy a technical impracticability waiver (Goffredi 1997) and are as follows: 
1. Contaminants Low in Volatility: The vapor pressures of the contaminants of concern at the QROU - which include nitroaromatic compounds (2,4-DNT $5.1 \times 10^{-3} \mathrm{~mm}$ mercury; 2,6-DNT: $1.8 \times 10^{-2} \mathrm{~mm}$ mercury) and uranium (vapor pressure effectively zero because uranium is a nonvolatile solid) - are all very low. Thus these contaminants are considered to have low volatility.

2. Large Volume of Contaminated Media: A large volume of aquifer could potentially be contaminated, about 0.5 million $\mathrm{m}^{3}\left(19\right.$ million $\left.\mathrm{ft}^{3}\right)$.

3. Complex Geology: The alluvial aquifer contains clay, silt, sand, and gravel intermixed and interbedded (DOE 1994b). The fine-grained alluvium itself consists of silty clay and clayey silt with alternating layers and lenses of fine sand, sandy silt, sandy clay, and stiff clay with gravel (DOE 1998a).

4. Heterogeneous Underlying Stratigraphy: The shallow groundwater system is composed of carbonate rocks near the quarry, tributary alluvium near Little Femme Osage Creek, and Missouri River alluvium between the quarry bluff and the Missouri River. Groundwater flow through the saturated carbonate rocks is governed by joints and fractures in the underlying limestone (DOE 1994b). The alluvial aquifer is composed of interbedded clay, silt, sand, and gravel.

5. Low Hydraulic Conductivity of the Contaminated Aquifer (less than $1 \times 10^{-4} \mathrm{~cm} / \mathrm{s}$ ): The conductivity of the alluvium north of the slough ranges from $1 \times 10^{-5}$ to $1 \times 10^{-3} \mathrm{~cm} / \mathrm{s}$. Pump tests conducted on six wells in the alluvium north of the slough indicate that yields greater than $1.9 \mathrm{~L} / \mathrm{min}$ $(0.5 \mathrm{gpm})$ could not be maintained in four of the wells (DOE 1998a).

6. High Temporal Variation in Groundwater Flow Regime: Groundwater flow in the vicinity of the quarry occurs in alluvium, fractured limestone, and sandstone. Different regimes of groundwater flow exist within the shallow groundwater system.

Further, EPA guidance (EPA 1988b) states that hydrogeologic constraints may limit the effectiveness of active remediation when plumes migrate into formations from which they cannot easily be removed. In these special situations, no active remediation coupled with monitoring and institutional controls has been identified by the EPA (1988b) as potentially being the only feasible remedy. These situations include sites at which contaminant migration occurs from fractured bedrock, as well as sites at which the transmissivity of the aquifer is less than $5.4 \times 10^{-5} \mathrm{~m}^{2} / \mathrm{s}$ $\left(50 \mathrm{ft}^{2} / \mathrm{d}\right)$. The conceptual fate and transport model for the quarry area provided in DOE (1998a) indicates that the migration of contaminants from the quarry proper occurs via fracture flow into the 
three bedrock aquifers (Kimmswick Limestone, Decorah Limestone, and Plattin Limestone): groundwater movement in limestone in the vicinity of the quarry occurs primarily within fractures: and long bedding planes. The average transmissivity of the fractured limestone in the quarry area has been estimated to be approximately $4.9 \times 10^{-5} \mathrm{~m}^{2} / \mathrm{s}\left(46 \mathrm{ft}^{2} / \mathrm{d}\right)$ (DOE 1994b). The transmissivity of the alluvial aquifer itself ranges from about $4.8 \times 10^{-5}$ to $1.2 \times 10^{-4} \mathrm{~m}^{2} / \mathrm{s}$ (45 to $107 \mathrm{ft} / \mathrm{d}$ ) (DOE 1998a), which indicates that these conditions might be applicable at the quarry area. In general, the hydraulic conductivities in the alluvium north of the slough (less than $10^{-4} \mathrm{~cm} / \mathrm{s}[0.3 \mathrm{ft} / \mathrm{d}]$ ) would. limit groundwater extraction using conventional means.

The EPA (1988b) also indicates that no active remediation coupled with monitoring and institutional controls may be the most practicable response when contaminants are expected to attenuate to health-based values in a relatively short distance. For the materials previously disposed of in the quarry (from 1957 to 1966), significant contaminant migration in groundwater to areas: south of the quarry and up to Femme Osage Slough (a distance of $0.2 \mathrm{~km}$ [0.13 mi]) has not been detected over the last 40 years. The contaminants in the quarry aquifer system are attenuated by sorption, biodegradation, and/or precipitation. Uranium precipitates from groundwater under: reducing conditions; reducing conditions also favor the initial degradation of nitroaromatic: compounds. Near the slough, oxidizing conditions abruptly give way to reducing conditions, defining; a reduction front along the low-lying, poorly drained area adjacent to the slough (DOE 1998a). Recent testing of soil and groundwater from the contaminated area has shown higher $\mathrm{K}_{\mathrm{d}}$ values thar. originally estimated. These results indicate that the migration is even slower than was previously calculated, which suggests that sorption is a major mechanism in retarding uranium migration. It is; within this relatively short distance that the contaminants are projected to attenuate to health-based values.

\subsubsection{Long-Term Effectiveness and Permanence}

Under current conditions, the contaminated groundwater north of the slough poses no imminent risk to the St. Charles County well field or the environment south of the slough. Contaminated groundwater would be removed and treated, which would reduce the potential for: further migration of uranium south of the Femme Osage Slough. The treatment system itself would be equipped with automated shutdown controls, secondary containment measures, and effluent concentration monitoring. These control measures would adequately protect human health and the environment should problems such as equipment failure, leaks, or spills arise.

Monitoring and maintenance activities would be carried out by DOE for a period of time specified in the ROD. Protection of human health and the environment in the extended future would be ensured, because investigative and monitoring activities by DOE would continue and allow consideration of active response measures if future migration of residual contamination resulted in unacceptable exposure concentrations at the well field. The potential for further migration off 
uranium south of the Femme Osage Slough would be reduced because of the reduction in the mass of uranium in the quarry alluvial aquifer. Unacceptable impacts to human health and the environment are, however, not expected to occur on the basis of indications from monitoring data obtained for the last 10 years and current and foreseeable future land use.

\subsubsection{Protection of Workers}

Long-term monitoring and maintenance activities would be carried out for a period of time specified in the ROD. Workers would be present on-site periodically to perform these activities. The potential impact on sampling personnel from exposure to contaminants would be low.

The risks to workers associated with groundwater extraction, handling treatment residuals, and $O \& M$ of treatment process equipment would be low.

Groundwater extraction and treatment and monitoring activities over a 30-year period are estimated to result in approximately 19 cases of occupational injury and no occupational fatalities (Appendix D); these estimates are based on industry-specific statistics from the U.S. Bureau of Labor Statistics, as reported by the National Safety Council (1995). Standard operating procedures would be established to define proper treatment system operating parameters and maintenance requirements to ensure the safety and health of the workforce. Alternative 6 would, therefore, pose low long-term risks to workers.

\subsubsection{Protection of the Public}

Following implementation of the two-year groundwater extraction and treatment phase of Alternative 6, routine groundwater monitoring and maintenance activities would ensure that uranium in the groundwater did not migrate to the St. Charles County well field. However, if future migration of residual contamination did occur in unacceptable exposure concentrations at the well field, investigative and monitoring activities by DOE would continue and allow consideration of contingency measures. Releases of site contaminants over the long term are expected to be low, Similar to Alternative 2, unacceptable risks to the general public would not be expected to occur under Alternative 6, even if conditions would remain as they are now. However, with monitoring, information on future concentrations of contaminants in groundwater would be available to confirm the expectation that unacceptable risks would not occur under Alternative 6. 


\subsubsection{Environmental Protection (Water Quality and Hydrology)}

Water quality and hydrology, on a relative scale, would be better under Alternative 6 compared to Alternative 1. Assuming that the groundwater extraction design flow rate of $1.3 \mathrm{~L} / \mathrm{s}$ (20 gpm) can be achieved, preliminary calculations (see Section 3.2.2.6) indicate that the two-year groundwater extraction and treatment activity proposed in Alternative 6 would result in an 8 to 10\% reduction in the mass of uranium in the alluvial aquifer, and thereby an 8 to $10 \%$ reduction in the uranium concentration at a single county well.

\subsubsection{Reduction of Toxicity, Mobility, and Volume through Treatment}

Alternative 6 would satisfy the statutory preference for treatment as a principal element of remediation and would provide a reduction in the toxicity, mobility, and volume of the contaminated groundwater through treatment. Alternative 6 would reduce mobility by hydraulically controlling: contaminated groundwater migration north of the Femme Osage Slough through extraction of contaminants. The mobility of uranium and other contaminants removed by ion exchange would be minimized by subsequent disposal at an approved facility. Other treatment residuals (such as settling tank sludge) may be solidified in cement prior to disposal. The reduction in volume of contaminated groundwater is equal to the volume treated (which is equivalent to the design flow rate of $1.3 \mathrm{~L} / \mathrm{s}$ [20 gpm] multiplied by the operation time), approximately 80 million liters ( 20 million gallons) by the end of the two-year period. Uranium removal from the quarry groundwater would reduce the threat posed by groundwater migration south of the slough. Groundwater modeling using analytical methods indicates that the effect of the extraction system can reduce the mass of uranium within the alluvial aquifer by 8 to $10 \%$ relative to the baseline (i.e., no action).

\subsubsection{Short-Term Effectiveness}

Risks to workers would be due primarily to physical hazards during construction activities. Construction activities are estimated to result in less than two cases of occupational injury and no occupational fatalities (Appendix D). This estimate is based on industry-specific statistics from the U.S. Bureau of Labor Statistics, as reported by the National Safety Council (1995). Physical hazards would be minimized by adherence to stringent health and safety protocols.

Minimal environmental impacts would result from interceptor trench construction. The: primary impact to the environment would be associated with installation of the interceptor trench and construction of a piping system to transport groundwater from the trench for treatment. These activities may result in physical disturbances of habitat, but would be of short duration. Some shortterm impacts on recreational use of the surrounding wildlife areas might occur as a result of noise, exhaust fumes, and dust associated with any construction activities. Impacts to biological resources 
would be mitigated by avoiding unnecessary damage to vegetation, wildlife, and soil through controlling traffic and minimizing the areas of disturbance.

During construction of the interceptor trench and the additional monitoring wells, the amount of criteria pollutants emitted as a result of equipment operations and transportation (by car) of the construction personnel to the quarry area would be low (e.g., less than 3,000 kg [6,600 lb] of $\mathrm{NO}_{\mathrm{x}}$ emitted during the entire construction period [Appendix D]), and as such, would not contribute to any off-site health impacts. Emissions of TSP were estimated to be approximately $22,000 \mathrm{~kg}$ $(48,000 \mathrm{lb})$, assuming that all vehicles traveled over unpaved roads without any control measures. Vehicle traffic on unpaved surfaces, earthmoving, excavating, and bulldozing would be the major sources of TSP. TSP generation during actual construction activities would be suppressed by watering, revegetation of bare areas, covering of open trucks carrying dusty material, removal of dirt and debris from the road surface, and the use of containment methods whenever feasible.

Accounting for transport of groundwater treatment residuals and worker commuter vehicles, the annual emission rate of criteria pollutants from worker vehicles would be low (e.g., less than $100 \mathrm{~kg}$ [450 lb] per year of CO emitted [Appendix D]) and would not contribute to any off-site health impacts. These temporary impacts would be limited to the immediate vicinity of the quarry area, and mitigative measures would be applied to ensure minimal impacts to off-site areas.

\subsubsection{Implementability}

Few implementability concerns would be posed by Alternative 6 . Because groundwater extraction and treatment are well-developed technologies, technical problems are not likely to cause significant delays. One possible problem considered is the potential for the groundwater extraction system to not achieve the design flow rate of $1.3 \mathrm{~L} / \mathrm{s}(20 \mathrm{gpm})$. This situation could result in schedule delays. Site operations would continue to use readily available resources for monitoring. Construction of any new monitoring wells would simply require mobilization of a drilling rig for installation. Minimal administrative complexities, including permit applications, would be associated with monitoring well installation. Discharge of treated groundwater into the Missouri River would likely require coordination with other agencies such as the EPA and the Missouri Department of Natural Resources.

Potential use of the QWTP and associated discharge points would reduce the inherent technical difficulties in licensing wastewater treatment facilities. In the event that the QWTP is unavailable, groundwater treatment services are commercially available, and equipment and specialists are available within DOE and private industry. The groundwater treatment technologies considered for the portable unit are well developed and proven effective from QWTP operations. Further development of these technologies would not be required before they could be applied at the site. Disposal services would be available within the WSSRAP on-site disposal cell. 
Groundwater monitoring could be readily implemented. Numerous wells currently exist at the quarry area, and additional wells could be easily installed and monitored. Monitoring of plume migration would be relatively easy to implement. The results from sampling of the existing network of monitoring wells would be used to identify the potential for significant exposure before it occurred at the well field. Therefore, taking additional actions prior to significant exposure at the well field would be relatively easy.

The administrative feasibility of Alternative 6 would be relatively straightforward. Remedial activities at the Weldon Spring site are coordinated with the State of Missouri and EPA Region VII. That coordination would continue during the implementation of Alternative 6 , and no additional coordination for monitoring activities would be required with any other agencies beyond that already occurring.

New permits or licenses for on-site activities might be required to implement Alternative 6 . State and/or federal permits may be required for an off-site contractor to bring its portable treatment unit to the Weldon Spring site. License acquisition (for temporary possession of the uranium removed in the portable treatment unit) may be required by the off-site contractor to implement this alternative.

\subsubsection{Cost}

Costs for this alternative would be associated with continuing the existing environmental monitoring program, constructing and operating groundwater extraction and treatment systems (if the QWTP is unavailable), constructing and operating possible new monitoring wells, and conducting a performance review at least every five years. Feasibility-level cost estimates were prepared using standard cost-estimating sources.

The costs for individual construction activities were taken from the latest version of the Unit Price Book developed by the U.S. Army Corps of Engineers (1989), except as noted below. A cost differential was included to account for the differences in material and labor costs for the Weldon Spring site, as compared with the generic Unit Price Book costs.

Cost estimates for major equipment used in the portable treatment units were obtained from vendors that supplied portable wastewater treatment modules (e.g., skid-mounted units) and by making engineering judgments. Trailer costs were obtained from suppliers and were adjusted to account for special process requirements. Costs for a parking pad with secondary containment were estimated with standard cost engineering references (R.S. Means 1994). It was assumed in the development of the costs of the portable treatment units that utilities would be available at the quarry site, that only tie-ins would be necessary, and that administrative support would be provided by DOE/WSSRAP. 
The estimated total and present-worth costs for Alternative 6 are given in Table 4.2; annual costs are estimated to be approximately $\$ 0.6$ million. The capital cost of Alternative 6 is estimated to be between $\$ 1$ and $\$ 2$ million (Appendix E), depending on whether the QWTP and the lower-cost single-pass trench construction are used. The capital cost would be primarily for the installation of the interceptor trench. The cost of the 1.3-L/s $(20-\mathrm{gpm})$ trailer-mounted water treatment unit was estimated to be approximately $\$ 0.6$ million.

Including the annual operating cost of the portable treatment unit and continued groundwater monitoring, the annual O\&M costs are estimated to be between $\$ 0.6$ million and $\$ 1$ million per year, depending upon the mode of treatment (QWTP versus portable units) and whether the costs of groundwater monitoring are included. The annual O\&M costs would be primarily for groundwater treatment (which ranges from $\$ 0.4$ to $\$ 0.5$ million per year).

TABLE 4.2 Cost Estimate for Alternative 6

\begin{tabular}{lc}
\hline \multicolumn{1}{c}{ Activity } & $\begin{array}{c}\text { Estimated Cost } \\
\text { (\$ million) }\end{array}$ \\
\hline Groundwater extraction construction & 1.4 \\
Groundwater treatment construction $^{\mathrm{a}}$ & 0 to 0.61 \\
Ground monitoring well construction $^{\mathrm{b}}$ & 0.15 \\
Groundwater extraction O\&M $^{\text {Groundwater treatment O\&M }}$ & 0.22 \\
Groundwater monitoring $^{\mathrm{c}}$ & 0.84 to 0.91 \\
Total $^{\mathrm{c}}$ & 0 to 11.4 \\
& \\
Present worth $^{\mathrm{c}}$ & 2.61 to 14.7 \\
\hline
\end{tabular}

a The higher end of the range will be incurred if a portable treatment unit is necessary.

b Based on construction of seven new wells.

c Estimated upper-bound cost for a 30-year period, assuming current sampling frequency for the existing network of monitoring wells. Any reduction in duration of monitoring, sampling frequency, or number of wells sampled would result in a proportional reduction in cost. 
Excluding the D\&D costs of the QWTP and the portable treatment units (which are highly speculative in the case of the portable unit), the 30-year present worth of Alternative 6 is estimated to range between $\$ 4$ million and $\$ 10$ million.

The costs associated with potential future actions, in the event that potential migration of residual contamination did result in unacceptable exposure concentrations, were not quantified because the uncertainty associated with these future activities precludes accurate assessment of these costs. 


\section{COMPARATIVE ANALYSIS OF ALTERNATIVES}

A comparison of the alternatives with regard to the nine evaluation criteria listed in Chapter 4 is presented in Sections 5.1 and 5.2. These criteria are categorized into the following three groups as stipulated in the NCP: threshold criteria, primary balancing criteria, and modifying criteria.

The threshold category contains the two criteria that each alternative must meet in order to be eligible for selection:

- Overall protection of human health and the environment; and

- Compliance with ARARs, unless a waiver condition applies.

These threshold criteria ensure that the remedial action selected will be protective of human health and the environment and that the action will either attain the ARARs identified at the time of the ROD or provide grounds for obtaining a waiver.

The primary balancing category contains the five criteria that are used to assess the relative advantages and disadvantages of each alternative to determine which alternative is most appropriate:

- Long-term effectiveness and permanence;

- Reduction of toxicity, mobility, or volume through treatment;

- Short-term effectiveness;

- Implementability; and

- Cost.

The first two criteria consider the preference for treatment as a principal element and the bias against off-site land disposal of untreated waste. Cost-effectiveness is determined by evaluating the following three of the five balancing criteria: long-term effectiveness and permanence; reduction of toxicity, mobility, or volume through treatment; and short-term effectiveness. Overall effectiveness is then compared with cost to ensure that the costs are proportional to the overall effectiveness of a remedial action. 
The modifying category consists of two criteria that are considered in remedy selection and. that will be addressed in the responsiveness summary and ROD to be prepared following the public comment period:

- State acceptance, and

- Community acceptance.

The two modifying criteria are not addressed in this comparative analysis.

The three final alternatives retained after screening are compared in Sections 5.1 and 5.2 for the threshold and primary balancing criteria, respectively. The results of this comparison are summarized in Table 5.1.

\subsection{THRESHOLD CRITERIA}

\subsubsection{Overall Protection of Human Health and the Environment}

Alternative 1 would be protective of human health and the environment over both the short: and the long term. Under current conditions, the groundwater north of the slough poses no imrninent: risk to human health at the St. Charles County well field or the environment south of the slough, on the basis of sampling data from the monitoring wells south of the slough and from the St. Charles County production wells. Although groundwater data would not be collected in the future by DOE, current data indicate that unacceptable exposure concentrations would not be expected to occur at: the well field. Estimation of the uranium concentration that would occur in the St. Charles County' water supply, assuming that there was breakthrough of the contamination past Femme Osage Sllough, indicates that the uranium concentration would not exceed $21 \mathrm{pCi} / \mathrm{L}$ in the well discharge, which would be below the metric of $30 \mathrm{pCi} / \mathrm{L}$.

Alternative 2 would also be protective of human health and the environment over the long; term. However, under this alternative, monitoring and investigative activities by DOE would identify any potential future plume migration and any variations in local geochemical conditions (e.g., Eh, $\mathrm{pH})$ that could adversely affect removal of contaminants from the groundwater by absorption, adsorption, precipitation, biodegradation, and other natural processes. The results from monitoring, activities would be used to assess the attainment of remediation goals and to track chemical distribution in the water-bearing zone. 


\section{TABLE 5.1 Comparative Analysis of Alternatives}

\begin{tabular}{ccc}
\hline & & Alternative 6: \\
Evaluation Criterion & $\begin{array}{c}\text { Alternative 1: } \\
\text { No Action }\end{array}$ & Alternative 2: \\
\hline
\end{tabular}

Overall protection of

human health and the

environment

Would be protective of human health and the environment in both the short and long term.

Uranium concentrations would not be below $30 \mathrm{pCi} / \mathrm{L}$ for a long period of time (i.e., $>1,000$ years). The concentrations of contaminants (uranium and nitroaromatic compounds) in quarry groundwater will continue to decrease with time because of the removal of the with time because of the removal of the
original source of the contamination and dilution from infiltration of rainwater and runoff and from sporadic local flooding. Therefore, all pertinent ARARs may be attained by the time the plume reaches the well field.

Long-term effectiveness and permanence

Future conditions are expected to be similar to current, if not better, because of the expected decrease (albeit slow) in contaminant concentrations as a result of source removal. In addition, contingency measures are provided in the Well Field Contingency Plan (DOE 1998c).
Would provide protection similar to Alternative 1. In addition, monitoring data would be collected to verify that conditions continue to be protective of human health and the environment.

Similar to Alternative 1.

Similar to Alternative 1. In addition, data would be available to verify that conditions at the quarry area continue to be protective of human health and the environment.
Would provide protection similar to Alternative 2 . In addition removal and treatment of a percentage of the contaminated volume of groundwater north of the slough would lead to a reduction in the amount of uranium that could potentially further migrate south of the slough toward the St. Charles County well field.

Similar to Alternative 2. In addition, for Alternative 6, pertinent ARARs associated with construction and relevant activities would be met.

Would be similar if not better than that of Alternative 2 because of the reduction in the amount of uranium that could potentially migrate toward south of the Femme Osage Slough into the St. Charles County well field. 
TABLE 5.1 (Cont.)

\begin{tabular}{|c|c|c|c|}
\hline Evaluation Criterion & $\begin{array}{l}\text { Alternative 1: } \\
\text { No Action }\end{array}$ & $\begin{array}{l}\text { Alternative 2: } \\
\text { Monitoring with No Active Remediation }\end{array}$ & $\begin{array}{c}\text { Alternative } 6 \text { : } \\
\text { Groundwater Removal at Selected Areas, } \\
\text { with On-Site Treatment } \\
\end{array}$ \\
\hline $\begin{array}{l}\text { Reduction of toxicity, } \\
\text { mobility, or volume } \\
\text { through treatment }\end{array}$ & $\begin{array}{l}\text { No immediate reduction of toxicity, } \\
\text { mobility, or volume because no } \\
\text { treatment would be performed. However, } \\
\text { the slow reduction of contaminant } \\
\text { concentrations is expected as a result of } \\
\text { natural processes occurring (i.e., sorption } \\
\text { and dilution). }\end{array}$ & Same as for Alternative $\mathrm{I}$. & $\begin{array}{l}\text { Would satisfy the statutory preference for treatment as a } \\
\text { principal element of remediation and would provide a } \\
\text { reduction in the toxicity, mobility, or volume of the } \\
\text { contaminated groundwater through treatment. The effects of } \\
\text { the extraction system may reduce the mass of uranium within } \\
\text { the alluvial aquifer by } 8 \text { to } 10 \% \text { relative to the baseline (i.e., } \\
\text { no action). }\end{array}$ \\
\hline Short-term effectiveness & $\begin{array}{l}\text { No potential impacts on workers or the } \\
\text { environment, because no activities would } \\
\text { be undertaken. }\end{array}$ & $\begin{array}{l}\text { Expected to be low, with less than one case of } \\
\text { occupational injury and no occupational fatalities during } \\
\text { proposed monitoring well construction. Any potential } \\
\text { short-term environmental impacts would be limited to the } \\
\text { immediate vicinity of the quarry area, and mitigative } \\
\text { measures would be applied to minimize potential } \\
\text { impacts. }\end{array}$ & $\begin{array}{l}\text { Similar to Alternative } 2 \text {. Expected to be low, with less than } \\
\text { two cases of occupational injury and no occupational fatalities } \\
\text { during proposed construction activities. }\end{array}$ \\
\hline Implementability & $\begin{array}{l}\text { No implementability concerns because } \\
\text { no action would be taken. }\end{array}$ & $\begin{array}{l}\text { Few implementability concerns because of the limited } \\
\text { actions taken. Current monitoring operations would } \\
\text { continue with the use of readily available resources. }\end{array}$ & $\begin{array}{l}\text { Few implementability concerns. Groundwater extraction and } \\
\text { treatment are well-developed technologies. Further } \\
\text { development of these technologies would not be required. } \\
\text { New permits or licenses for on-site activities might be } \\
\text { required for potential use of portable treatment units. }\end{array}$ \\
\hline Cost & $\begin{array}{l}\text { No cost is expected to be associated with } \\
\text { this alternative. }\end{array}$ & $\begin{array}{l}\text { Can be considered to be cost-effective, because it would } \\
\text { provide overall protection of human health and the } \\
\text { environment for a reasonable cost. Costs are associated } \\
\text { with continuing the existing environmental monitoring } \\
\text { program, potential construction and operation of } \\
\text { additional monitoring wells, and conducting a } \\
\text { performance review at least every five years. Could be } \\
\text { implemented with existing resources and maintained at a } \\
\text { relatively low cost. }\end{array}$ & $\begin{array}{l}\text { Can be considered to be more cost-effective compared with } \\
\text { Alternatives } 1 \text { and } 2 \text {, because some uranium would be } \\
\text { removed from the groundwater at a reasonable cost. } \\
\text { Minimizes capital and annual cost expenditures by making } \\
\text { use of existing structures. Given site experience with the } \\
\text { QWTP and the SWTP, Alternative } 6 \text { could be primarily } \\
\text { implemented with existing resources and maintained at a long- } \\
\text { term cost similar to Alternative } 2 \text {. }\end{array}$ \\
\hline
\end{tabular}


Alternative 6 would reduce the volume of contaminants through treatment and be protective of human health and the environment over the long term. Like Alternative 2, monitoring and investigative activities by DOE under Alternative 6 would ensure that the remediation goal of providing further protection of the St. Charles County well field would be met and that the contaminant distribution in the water-bearing zone would be tracked. Contingency measures described in the Well Field Contingency Plan (DOE 1998c) would be considered to prevent unacceptable exposure concentrations at the St. Charles County well field. On the basis of the results summarized in Section 1.3, which are based on indications from monitoring data obtained for the last 10 years, unacceptable impacts to human health and the environment would not be expected to occur. As with Alternative 1, unacceptable impacts to human health and the environment would not be expected to occur under Alternative 2.

Under Alternatives 1 and 2, the currently contaminated groundwater would not be removed or treated. The overall protection of the environment in the long term would be provided by the slow reduction of contaminants by natural processes, including dilution from infiltration of rainwater and runoff and from sporadic local flooding.

\subsubsection{Compliance with ARARs}

A comprehensive list of potential ARARs is presented in Appendix A. Alternatives 1 and 2 would not attain certain applicable requirements, such as the standard for 2,4-DNT in groundwater, for a period of time. Current concentrations of 2,4-DNT in quarry groundwater are marginally greater than the standard of $0.11 \mu \mathrm{g} / \mathrm{L}$. In addition, a period of up to 1,000 years would be required for uranium concentrations to decrease to $30 \mathrm{pCi} / \mathrm{L}$ and below. For Alternative 6, some reduction (i.e., up to $10 \%$ ) of the original contaminated volume would be attained. In addition, under this alternative, a shorter period of time than that estimated for Alternatives 1 and 2 may be expected for the uranium concentration to decrease to $30 \mathrm{pCi} / \mathrm{L}$. However, the uncertainties associated with the degree of groundwater extraction and subsequent uranium removal makes it difficult to provide a reasonable estimate of this time period.

The groundwater north of the slough currently poses no imminent risk to human health at the St. Charles County well field or to the environment south of the slough. In the future, the concentration of contaminants in the area of the quarry will continue to decrease with time because of the removal of the original source of the contamination from the quarry, reduction and precipitation of uranium in the groundwater adjacent to the slough, and dilution from infiltration of rainwater and runoff and from sporadic local flooding. In addition, contingency measures discussed in the Well Field Contingency Plan (DOE 1998c) will be considered to ensure long-term protection of human health and the environment. 
A review will be conducted at least every five years because contamination would remain on-site at concentrations above levels that allow for unlimited use and unrestricted exposure.

Alternative 6 would be similar to Alternative 2, except that some amount (about 10\%) of: uranium is expected to be removed from the current existing mass in quarry groundwater north of: the slough. In addition, conditions at the quarry area are similar to those described in EPA guidance as satisfying technical impracticability.

\subsection{PRIMARY BALANCING CRITERIA}

\subsubsection{Long-Term Effectiveness and Permanence}

Under current conditions, the contaminated groundwater north of the slough poses no imminent risk to the St. Charles County well field or the environment south of the slough. Although contaminant concentrations would not be determined by DOE and, therefore, not available in the future, it is expected that unacceptable impacts to human health and the environment would not occur.

Under Alternative 2, monitoring and maintenance activities would be carried out at the quarry area for an indefinite period, which would provide adequate and reliable controls to manage the groundwater north of the slough. Long-term effectiveness of Alternative 2 would be ensured because investigative and monitoring activities would continue and would allow consideration of active response measures (via the Well Field Contingency Plan [DOE 1998c]) to prevent unacceptable exposure concentrations from occurring at the well field.

The long-term effectiveness of Alternative 6 would be similar if not better than that of Alternative 2 because of the reduction in the amount of uranium that could potentially migrate toward south of the Femme Osage Slough into the St. Charles County well field. The treatment system itself would be equipped with automated shutdown controls, secondary containment measures, and effluent concentration monitoring. These control measures would adequately protect human health and the environment should problems such as equipment failure, leaks, or spills arise.

\subsubsection{Reduction of Toxicity, Mobility, or Volume through Treatment}

Reduction of toxicity, mobility, or volume through treatment is not applicable to either Alternative 1 or 2 , since the contaminated groundwater would not be treated under either of these alternatives. Reduction of contaminant concentrations north of the slough would be the result of 
natural processes and by dilution of the contaminated groundwater with uncontaminated groundwater from infiltration of rainwater and runoff and from sporadic local flooding.

Alternative 6 would satisfy the statutory preference for treatment as a principal element of remediation and would provide a reduction in the toxicity, mobility, or volume of the contaminated groundwater through treatment. Alternative 6 would reduce mobility by hydraulically controlling contaminated groundwater migration north of the Femme Osage Slough through extraction of contaminants. The reduction in volume of contaminated groundwater would be equal to the volume treated (which is equivalent to the design flow rate $1.3 \mathrm{~L} / \mathrm{s}[20 \mathrm{gpm}$ ] multiplied by the operation time), that is, approximately 80 million liters (20 million gallons). Groundwater modeling using analytical methods indicates that the effect of the extraction system may reduce the mass of uranium within the alluvial aquifer by 8 to $10 \%$ relative to the baseline (i.e., no action).

\subsubsection{Short-Term Effectiveness}

For Alternative 1, conditions would essentially remain the same in the short term, and no significant changes in potential exposures would be expected because no activities would be undertaken. No potential impacts would occur to workers or the environment under Alternative 1.

The short-term impacts for Alternative 2 would be expected to be low; less than one case of occupational injury and no occupational fatalities would occur during proposed monitoring well construction. Potential short-term environmental impacts resulting from implementation of Alternative 2 would be limited to the immediate vicinity of the quarry area, and mitigative measures would be taken to ensure minimal impacts to off-site areas.

Similar to Alternative 2, the short-term impacts for Alternative 6 would be expected to be low, with less than two cases of occupational injury and no occupational fatalities due to physical hazards during construction activities. Potential short-term environmental impacts would be limited to the immediate vicinity of the quarry area (excluding the excavated soils from trench excavation that would be managed at the chemical plant area at Weldon Spring), and mitigative measures would be taken to ensure minimal impacts to off-site areas.

It has been estimated that remediation goals would require at least 100 years, on the basis of comparison with active remediation efforts.

\subsubsection{Implementability}

No implementability concerns would be posed by Alternative 1 because no action would be taken nor would any future activities be considered. Alternative 2 would pose few implementability 
concerns because resources would be readily available for groundwater monitoring, and additional wells could be easily installed, if appropriate. Monitoring the effectiveness of Alternative 2 would be relatively easy to implement. The administrative feasibility of Alternative 2 would be relatively straightforward, and no permits or licenses would be required.

Few implementability concerns would be posed by Alternative 6. Groundwater extraction and treatment are well-developed technologies. Potential use of the QWTP and its associated discharge point would reduce the inherent technical difficulties in licensing wastewater treatment facilities. In the event that the QWTP is unavailable, groundwater treatment services are commercially available, and equipment and specialists are available within DOE and private industry. The groundwater treatment technologies considered for the portable unit are well developed and proven effective from QWTP operations. Further development of these technologies will not be required before they can be applied at the site. Disposal services would be available within the WSSRAP on-site disposal cell. Similar to Alternative 2, the administrative feasibility of Alternative 6 would be relatively straightforward. New permits or licenses for on-site activities might, however, be required for an off-site contractor to bring its portable treatment unit to the Weldon Spring site and for temporary possession of the uranium removed in the portable treatment unit.

\subsubsection{Cost}

Alternative 1 would be the least expensive alternative in the short term because no activities would be undertaken and, thus, no present-worth, capital, or annual O\&M costs would be incurred. However, total costs could be the highest in the long term if, although unlikely, contaminated groundwater from the quarry area traveled south of the slough in high concentrations. Because all monitoring and investigative activities by DOE would have been halted, if conditions worsened considerably over time, an expensive emergency and/or expanded response might be required in the future. Thus, the cost-effectiveness of the No Action Alternative could be considered to be low in the long term.

Preliminary costs were estimated for Alternatives 2 and 6 for comparative purposes. Final costs will be developed during the detailed design stage following remedy selection. The total cost, long-term monitoring costs, and present-worth costs for Alternatives 2 and 6 are summarized in Tables 4.1 and 4.2 , respectively.

Compared with Alternative 1, Alternative 2 is considered to be the more cost-effective alternative because it would provide overall protection of human health and the environment for a reasonable cost. Costs for Alternative 2 would be associated with continuing the existing environmental monitoring program, constructing and operating any proposed new monitoring wells, and 
conducting a performance review at least every five years. Alternative 2 could be implemented with existing resources and maintained at a relatively low cost.

Alternative 6 can be considered to be more cost-effective compared with Alternatives 1 and 2 , because uranium would be removed from the groundwater at a reasonable cost. It minimizes capital and annual cost expenditures by making use of existing structures such as the QWTP and its associated permitted discharge point. Costs for Alternative 6 would be associated with continuing the existing environmental monitoring program, constructing and operating groundwater extraction and treatment systems (if the QWTP is unavailable), constructing and operating possible new monitoring wells, and conducting a performance review at least every five years. Given site experience with the QWTP and the Site Water Treatment Plant (SWTP), Alternative 6 could be primarily implemented with existing resources and maintained at a long-term cost similar to Alternative 2.

\subsection{SUMMARY}

The three final alternatives satisfy the threshold criteria for protecting human health and the environment and would attain contaminant-specific ARARs after a period of time. The monitoring component of Alternatives 2 and 6 would provide data to verify long-term protection of human health and the environment in the extended future. All alternatives would allow consideration of contingency measures to prevent unacceptable exposure concentrations at the well field. Any shortterm impacts associated with Alternatives 2 and 6 would be temporary and limited to the immediate vicinity of the quarry area, and mitigative measures would be applied to ensure minimal impacts to off-site areas. Alternative 6 would satisfy the statutory preferences for treatment as a principal element of remediation and would provide a reduction in the toxicity, mobility, and volume of the contaminated groundwater through treatment. Implementation of Alternative 2 would be straightforward because it would involve the groundwater monitoring system established at the quarry area and would not require any permits or licenses for on-site activities. Implementation of Alternative 6 would not be as straightforward as Alternative 2, since new permits or licenses might be required if a portable treatment unit is required. Alternative 6 is considered to be the more costeffective alternative because uranium would be removed from the groundwater at a reasonable cost. 


\section{REFERENCES}

Acar, Y.B., et al., 1993, "Fundamentals of Extracting Species from Soils by Electrokinetics," Waste Management 13:141-151.

Agrawal, A., and P.G. Tratnyek, 1996, "Reduction of Nitro Aromatic Compounds by Zero-Valent Iron Metal,” Environmental Science \& Technology 30(1):153-160.

Appleton, E.L., 1996, “A Nickel-Iron Wall Against Contaminated Groundwater,” Environmental Science and Technology 30(12):536A-539A.

Barton, L.L, et al., 1996, "Bacterial Reduction of Soluble Uranium: The First Step of In Situ Immobilization of Uranium," Radioactive Waste Management and Environmental Restoration 20:141-151.

Berkeley Geosciences Associates, 1984, Characterization and Assessment for the Weldon Spring Quarry Low-Level Radioactive Waste Storage Site, prepared by Berkeley Geosciences Associates, Berkeley, Calif., for Oak Ridge National Laboratory, Oak Ridge, Tenn., Sept.

Bibler, J.P., et al., 1992, Electrokinetic Migration Studies on Removal of Chromium and Uranyl Ions From 904-A Trench Soil, WSRC-RP-92-1207, Westinghouse Savannah River Co., Savannah River Technology Center, Savannah, Ga.

Booher, W.F., et al., 1997, Electrokinetic Removal of Uranium from Contaminated, Unsaturated Soils, SAND97-0122, Sandia National Laboratories, Albuquerque, N.M.

Bryda, L.K., and P.E. Morris, 1997, "Emerging Technologies for In-Situ Groundwater Remediation," Remediation (Summer):109-125.

Cantrell, K.J., et al., 1994, "Clinoptilolite as an In-Situ Permeable Barrier to Strontium Migration in Ground Water," in In-Situ Remediation: Scientific Basis for Current and Future Technologies, Part 2, G.W. Gee and H.R. Wing (editors), Battelle Press, Columbus, Ohio, pp. 839-850.

Cantrell, K.J., et al., 1995, "Zero-Valent Iron for the In Situ Remediation of Selected Metals in Groundwater," Journal of Hazardous Materials (42):201-212.

Cohen, R.M., et al., 1994, Methods for Monitoring Pump-and-Treat Performance, EPA/600/R-94/123, R.S. Kerr Environmental Research Laboratory, Ada, Okla.

Cooney, C.M., 1996, "Sunflowers Remove Radionuclides from Water in Ongoing Phytoremediation Field Tests," Environmental Science and Technology 30(5):194A. 
Crigler, D., 1992, personal communication from D. Crigler (Wildlife Management Biologist, August A. Busch Wildlife Area, St. Charles, Mo.) to G. Valett (Project Management Contractor, Weldon Spring Site Remedial Action Project, St. Charles, Mo.), as documented in memorandum from G. Valett to R. Ferguson (Jacobs Engineering Group, Weldon Spring Site Remedial Action Project, St. Charles, Mo.), May 21.

Dickneite, D.F., 1995, letter from D.F. Dickneite (Environmental Administrator, Missouri Department of Conservation, Jefferson City, Mo.) to S. Mc Cracken (Project Manager, Weldon Spring Site) with enclosure, Oct. 19.

DOE: see U.S. Department of Energy.

EPA: see U.S. Environmental Protection Agency.

Frazer, G.D., 1995, letter from G.D. Frazer (Field Supervisor, U.S. Fish and Wildlife Service, Columbia Field Office, Columbia, Mo.) to S.H. McCracken (U.S. Department of Energy, Weldorı Spring Site Remedial Action Project, St. Charles, Mo.), May 12.

Freeman, H.D., et al., 1986, Engineered Sorbent Barrier for Low-Level Waste Disposal, PNL-6051. Pacific Northwest Laboratory, Richland, Wash.

Gleason, M.H., et al., 1997, "Calcium and Sodium Bentonite for Hydraulic Containmen: Applications," Journal of Geotechnical and Geoenvironmental Engineering 123(5):438-44.5.

Goffredi, P.E. (editor), 1997, “Technical Impracticability Waivers Provide Relief from Unattainable: Remediation Goals," The Hazardous Waste Consultant (Jan./Feb.):1.27-1.31.

Hood, F., 1997, personal communication from F. Hood (MK-Ferguson Company, Boise, Idaho) to S. Folga (Argonne National Laboratory, Argonne, Ill.), March 13.

Horstmann, P., 1997, personal communication from P. Horstmann (Argonne National Laboratory, Argonne, Ill.) to S. Folga (Argonne National Laboratory, Argonne, Ill.), May 27.

Ivanovich, M., and R.S. Harmon, eds., 1992, Uranium-Series Disequilibrium: Applications to Earth, Marine, and Environmental Sciences, 2nd ed., Clarendon Press, Oxford, United Kingdom.

Kleeschulte, M.J., and L.F. Emmett, 1986, Compilation and Preliminary Interpretation of Data for the Weldon Spring Radioactive Waste-Disposal Sites, St. Charles County, Missouri-A Progress Report, U.S. Geological Survey Water-Resources Investigation Report 85-4272. 
Marks, P.J., et al., 1994, Remediation Technologies Screening Matrix and Reference Guide, Second Edition, SFIM-AEC-ET-CR-94065, prepared by Roy F. Weston, Inc., for U.S. Army Environmental Center, Aberdeen Proving Ground, Md., Oct.

Miller, R.R., 1996a; Artificially-Induced or Blast-Enhanced Fracturing, Technology Overview Report TO-96-01, Ground-Water Remediation Technologies Analysis Center, Pittsburgh, Penn., June.

Miller, R.R., 1996b, Phytoremediation, Technology Overview Report TO-96-03, Ground-Water Remediation Technologies Analysis Center, Pittsburgh, Penn., Oct.

MK-Ferguson Company and Jacobs Engineering Group, 1995, Radiological and Chemical Uptake in Game Species at the Weldon Spring Site, DOE/OR/21548-426, prepared for U.S. Department of Energy, Oak Ridge Operations Office, Weldon Spring Site Remedial Action Project, Weldon Spring, Mo., July.

Morrison, S.J., and R.R. Spangler, 1992, "Extraction of Uranium and Molybdenum from Aqueous Solutions: A Survey of Industrial Materials for Use in Chemical Barriers for Uranium Mill Tailings Remediation," Environmental Science and Technology 26(10):1922-1931.

National Research Council, 1994, Alternatives for Groundwater Cleanup, National Academy Press, Washington, D.C.

National Safety Council, 1995, Accident Facts, Itasca, Ill.

Naval Energy and Environmental Support Activity, 1991, French Drain System for Site Remediation, Technology Transfer Package, May.

Negri, M.C., and R.R. Hinchman, 1996, "Plants that Remove Contaminants from the Environment," Laboratory Medicine 27:36-40.

Richardson Engineering Services, 1993, Process Plant Construction Estimating Standards, Volume 1: Sitework, Piping, Concrete, Richardson Engineering Services, Inc., Mesa, Ariz.

R.S. Means Company, Inc., 1994, Means Building Construction Cost Data: 53rd Annual Edition, Kingston, Mass.

Shropshire, D., et al., 1995, Waste Management Facilities Cost Information for Mixed Low-Level Waste, INEL-95/0014, Revision 1, prepared by Lockheed Idaho Technologies Company for Idaho National Engineering Laboratory, Idaho Falls, Idaho, June. 
Turney, W.R., et al., 1994, Heap Leach Studies on the Removal of Uranium from Soil, LA-UR-94-1361, Los Alamos National Laboratory, Los Alamos, N.M.

U.S. Army Corps of Engineers, 1989, Computer Aided Cost Engineering Support System: Description and Overview, Office of the Chief of Engineers, Arlington, Va., May 1.

U.S. Bureau of the Census, 1991, 1990 Census of Population and Housing, U.S. Department of Commerce, Washington, D.C.

U.S. Department of Defense, 1994, Remediation Technologies Screening Matrix and Reference Guide, EPA/542/B-94/013, 2nd ed., Environmental Technology Committee, National Center for Environmental Publications and Information, Cincinnati, Ohio.

U.S. Department of Energy, 1991, Selection of Water Treatment Processes Special Study, DOE/UMTRA-400675-0000, prepared by Uranium Mill Tailings Remedial Action Project Office, Albuquerque Operations Office, Albuquerque, N.M.

U.S. Department of Energy, 1992, Mobile Water Treatment Plant Special Study, DOE/UMTRA400681-0000, prepared by Uranium Mill Tailings Remedial Action Project Office, Albuquerque, N.M., Dec.

U.S. Department of Energy, 1993a, Phase I and II Feasibility Study Report for the 300-FF-.5 Operable Unit, DOE/RL-93-22, Rev. 0, Richland Operations Office, Richland, Wash.

U.S. Department of Energy, 1993b, Record of Decision for Remedial Action at the Chemical Plant Area of the Weldon Spring Site, DOE/OR/21548-376, Oak Ridge Field Office, Weldon Spring Site Remedial Action Project, Weldon Spring, Mo., Sept.

U.S. Department of Energy, 1994a, 100-HR-3 Operable Unit Focused Feasibility Study Report, DOE/RL-94-67, Draft A, Richland Operations Office, Richland, Wash., Sept.

U.S. Department of Energy, 1994b, Work Plan for the Remedial Investigation/Feasibility Study-Environmental Assessment for the Quarry Residuals Operable Unit at the Weldon Spring Site, DOE/OR/21548-243, Weldon Spring Site Remedial Action Project, St. Charles, Mo., Jan.

U.S. Department of Energy, 1995, "Technology and Systems Solutions: Supported Liquid Membranes," [URL http://em-50.em.doe.gov/BEST/techs/rd/tech0296.html], accessed Oct 16, 1997.

U.S. Department of Energy, 1996, Subsurface Contaminants Focus Area, Technology Summary, Office of Science and Technology, Aug. 
U.S. Department of Energy, 1998a, Baseline Risk Assessment for the Quarry Residuals Operable Unit of the Weldon Spring Site, Weldon Spring, Missouri, DOE/OR/21548-594, prepared by Argonne National Laboratory, Argonne, Ill., for Oak Ridge Operations Office, Weldon Spring Site Remedial Action Project, Weldon Spring, Mo., Feb.

U.S. Department of Energy, 1998b, Remedial Investigation for the Quarry Residuals Operable Unit of the Weldon Spring Site, Weldon Spring, Missouri, DOE/OR/21548-587, Rev. 0, prepared by MK-Ferguson Company and Jacobs Engineering Group, Weldon Spring, Mo., for U.S. Department of Energy, Oak Ridge Operations Office, Weldon Spring Site Remedial Action Project, Weldon Spring, Mo., Feb.

U.S. Department of Energy, 1998c, Well Field Contingency Plan, prepared by MK-Ferguson Company and Jacobs Engineering Group, Weldon Spring, Mo., for U.S. Department of Energy, Oak Ridge Operations Office, Weldon Spring Site Remedial Action Project, Weldon Spring, Mo.

U.S. Environmental Protection Agency, 1986, Handbook: Remedial Action at Waste Disposal Sites, EPA/625/6-85/006, Washington, D.C.

U.S. Environmental Protection Agency, 1987, "National Priorities List for Uncontrolled Hazardous Waste Sites; Final Rule (40 CFR Part 300)," Federal Register 52:27620, July 22.

U.S. Environmental Protection Agency, 1988a, Guidance for Conducting Remedial Investigations and Feasibility Studies under CERCLA, Interim Final, EPA/540/G-89/004 (OSWER Directive 9355.3-01), Office of Emergency and Remedial Response, Washington, D.C., Oct.

U.S. Environmental Protection Agency, 1988b, Guidance on Remedial Actions for Contaminated Groundwater at Superfund Sites, EPA/540/G-88/003, Interim Final, Office of Emergency and Remedial Response, Washington, D.C., Dec.

U.S. Environmental Protection Agency, 1989, Risk Assessment Guidance for Superfund, Volume I: Human Health Evaluation Manual (Part A), Interim Final, EPA/540/1-89/002, Office of Emergency and Remedial Response, Washington, D.C., Dec.

U.S. Environmental Protection Agency, 1990a, "National Oil and Hazardous Substances Pollution Contingency Plan; Final Rule (40 CFR Part 300)," Federal Register 55(46):8666-8865, March 8.

U.S. Environmental Protection Agency, 1991, "National Primary Drinking Water Regulations: Radionuclides; Notice of Proposed Rulemaking," Federal Register 56:33050-33051, July 18. 
U.S. Environmental Protection Agency, 1993a, Handbook, Approaches for the Remediation of Federal Facility Sites Contaminated with Explosive or Radioactive Wastes, EPA/625/R-93/013, Office of Research and Development, Washington, D.C., Sept.

U.S. Environmental Protection Agency, 1993b, Revision to OMB A-94, Average Discount Rate for Beneficial Cost Analysis, OSWER Directive 9355.3-20, Washington, D.C., June.

U.S. Environmental Protection Agency, 1995, In Situ Remediation Technology: Electrokinetics, EPA 542-K-94-007, Office of Solid Waste and Emergency Response, Washington, D.C., April.

U.S. Environmental Protection Agency, 1996a, Presumptive Response Strategy and Ex-Situ Treatment Technologies for Contaminated Ground Water at CERCLA Sites, Final Guidance, EPA 540/R-96/023, Office of Solid Waste and Emergency Response, Washington, D.C., Oct.

U.S. Environmental Protection Agency, 1996b, Pump-and-Treat Ground-Water Remediation, A Guide for Decision Makers and Practitioners, EPA/625/R-95/005, prepared by Eastern Research Group, Inc., for the U.S. Environmental Protection Agency, Office of Research and Development, National Risk Management Research Laboratory, Center for Environmental Research Information, Cincinnati, Ohio.

U.S. Environmental Protection Agency, 1997, Rules of Thumb for Superfund Remedy Selection, EPA 540/R-97/013, Office of Solid Waste and Emergency Response, Washington, D.C., Aug.

Valett, G., 1997, personal communication from G. Valett (MK-Ferguson Company, St. Charles, Mo.) to S. Folga (Argonne National Laboratory, Argonne, Ill.), March 25.

Vidic, R.D., and F.G. Pohland, 1996, Treatment Walls, Technology Evaluation Report TE-96-01, prepared by University of Pittsburgh for Ground-Water Remediation Technologies Analysis Center, Pittsburgh, Penn., Oct.

Wagner, K., et al., 1986, Remedial Action Technology for Waste Disposal Sites, 2nd ed., Noyes Data Corporation, Park Ridge, N.J.

Whitfield, J.W., et al., 1989, Geologic Map of the Weldon Spring 7.5 Quadrangle, St. Charles County, Mo., OFM-89-252-FI, Missouri Department of Natural Resources, Division of Geology and Land Survey, Rolla, Mo.

Wong, J.H.C., et al., 1997, Design of Remediation Systems, CRC Press, Inc., Boca Raton, Fla. 
APPENDIX A:

REGULATORY REQUIREMENTS POTENTIALLY APPLICABLE OR RELEVANT AND APPROPRIATE TO THE REMEDIAL ACTION 


\section{APPENDIX A:}

\section{REGULATORY REQUIREMENTS POTENTIALLY APPLICABLE OR RELEVANT AND APPROPRIATE TO THE REMEDIAL ACTION}

\section{A.1 INTRODUCTION}

The U.S. Environmental Protection Agency (EPA) has promulgated implementing regulations for the Comprehensive Environmental Response, Compensation, and Liability Act (CERCLA), as amended; these regulations are presented in the National Oil and Hazardous Substances Pollution Contingency Plan (NCP) (40 Code of Federal Regulations Part [CFR] 300). This feasibility study (FS) follows the feasibility study process for sites on the National Priorities List (NPL). Under this process, remediation alternatives for the quarry residuals operable unit (QROU) were developed on the basis of remediation goals and potentially suitable technologies. The short-term and long-term aspects of three criteria (effectiveness, implementability, and cost) guided, as appropriate, the development and screening of alternatives. Alternatives that remained after this initial screening were analyzed in detail by assessing the individual alternatives against each of the nine evaluation criteria, including compliance with "applicable or relevant and appropriate requirements" (ARARs).

The NCP specifies that the evaluation of alternatives for remedial action at an NPL site must include an assessment of whether the alternatives will attain ARARs under federal environmental laws and state environmental or facility siting laws or grounds for invoking one of the waivers (40 CFR 300.430(e)(9)(iii)(B)) must be provided. To be eligible for selection as the remedy for an NPL site, an alternative must attain ARARs unless a waiver is appropriate (40 CFR $300.430(f)(1)(i)(A))$. Other advisories, criteria, or guidance developed by the EPA, other federal agencies, or states, which might be useful for developing the remedy for an NPL site, can also be considered as part of the alternatives evaluation (40 CFR 300.400(g)(3)). These other measures are called "to-be-considered," or TBC, requirements.

The ARARs are standards properly promulgated under federal or state statutes that might be applicable or relevant and appropriate to all or part of the action. Only those state requirements that are (1) promulgated such that they are of general applicability and legally enforceable, (2) identified by the state in a timely manner, and (3) more stringent than federal requirements will be considered ARARs (40 CFR $300.400(\mathrm{~g})(4)$ ). The TBCs are standards or guidelines that have not been properly promulgated (i.e., a process including publication, comment, and formal adoption under applicable federal or state administrative regulations). The TBCs would include U.S. Department of Energy (DOE) Orders or proposed state or federal agency regulations that might be pertinent to the action being considered. In addressing a requirement that might affect a remedial action being considered for a site, a determination is made regarding its relationship to (1) the 
location of the action, (2) the contaminants involved, and (3) the specific components of the action, such as factors unique to a certain technology.

Any regulation, standard, requirement, criterion, or limitation under any federal or state: environmental law or state facility siting law may be either applicable or relevant and appropriate: to a remedial action, but not both. Applicable requirements are cleanup standards; standards of control; or other substantive environmental protection requirements, criteria, or limitations promulgated under federal or state laws that specifically address a hazardous substance, pollutant. contaminant, remedial action, location, or other circumstance at a CERCLA site (40 CFR 300.5). Relevant and appropriate requirements are cleanup standards, standards of control, or other substantive environmental protection requirements, criteria, or limitations promulgated under federal or state: laws that are not applicable but that address problems or situations sufficiently similar to those: encountered at the CERCLA site that their use is well suited to the particular site (40 CFR 300.5). If the requirement is not legally applicable to the remedial action, a determination must be made as: to whether the requirement is both relevant and appropriate. For this determination, the requirement: must be considered sufficiently similar to the circumstances of the action, and it must also be well. suited to the site. The requirement must be both relevant and appropriate, based on best professional. judgment, and in some circumstances, a requirement may be relevant but not appropriate for the sitespecific situation. Under the NCP, the following comparisons must be made to determine relevance: and appropriateness:

- The purpose of the requirement and the purpose of the CERCLA action;

- The medium regulated or affected by the requirement and the medium contaminated or affected at the CERCLA site;

- The substances regulated by the requirement and the substances found at the CERCLA site;

- The actions or activities regulated by the requirement and the remedial action contemplated at the CERCLA site;

- Any variance, waivers, or exemptions for the requirement and their availability for the circumstances at the CERCLA site;

- The type of place regulated and the type of place affected by the release or CERCLA action;

- The type and size of structure or facility regulated and the type and size of structure or facility affected by the release or contemplated by the CERCLA site; and 
- Any consideration of use or potential use of affected resources in the requirement and the use or potential use of the affected resource at the CERCLA site.

On-site actions must comply with all substantive provisions of an ARAR, but not with related administrative and procedural requirements (e.g., filing reports or obtaining a permit). Only applicable requirements are evaluated for off-site actions, whereas both applicable and relevant and appropriate requirements are evaluated for on-site actions. On-site includes the areal extent of contamination and all suitable areas in very close proximity to the contamination necessary for implementation of the response action. This would include any activity within the quarry area and other areas contaminated by the migration of a hazardous substance, pollutant, or contaminant from any of the areas under the custody and accountability of DOE. No permit application would be necessary for any on-site activities, even if the response action could result in discharges or releases that subsequently migrate beyond site boundaries (Browner 1995).

Potential TBC requirements are typically considered only if no promulgated requirements exist that are either applicable or relevant and appropriate. TBCs are to be used on an "as appropriate" basis, such as when ARARs do not exist for a contaminant or circumstance (55 Federal Register [FR] 8745; March 8, 1990). Because the Weldon Spring site is a DOE facility, applicable DOE Orders, standards, and guidance will be followed, irrespective of their TBC designations under the ARAR process.

For groundwater remedial actions, CERCLA Section 121(d) states that a remedial action will attain a level or standard of control established under the Safe Drinking Water Act (SDWA), where such level or standard of control is applicable or relevant and appropriate to any hazardous substance, pollutant, or contaminant that will remain on-site. The enforceable standards under the SDWA are maximum contaminant levels (MCLs), which represent the maximum permissible level of a contaminant that is delivered to any user of a public water system. Because MCLs are usually only legally applicable under the SDWA to the quality of drinking water at the tap, there will be few instances in which MCLs are applicable to cleanup of groundwater at a site. For this reason, MCLs are generally considered "relevant and appropriate" to groundwater that is or may be used for drinking.

Section 121(d) also states that remedial actions shall attain maximum contaminant level goals (MCLGs) where such goals are relevant and appropriate to the circumstances of the release. It is the EPA's opinion that where an MCLG establishes a contaminant level above zero, it is appropriate and consistent with CERCLA language to consider the MCLG as a potential relevant and appropriate requirement, with determinations to be made on a site-specific basis as to the relevance and appropriateness of meeting that level under the circumstances of the release. When an MCLG is determined not to be relevant and appropriate to the circumstances of the release, the corresponding MCL will be considered a potential relevant and appropriate requirement and will be 
evaluated under the circumstances of the release. However, where an MCLG is equal to zero level of contaminants (as is the case for carcinogens), the MCLG is not "appropriate" for the cleanup of groundwater at CERCLA sites. In such cases, the corresponding MCL will be considered as a potential relevant and appropriate requirement.

Under the NCP, an alternate concentration limit (ACL) may be established in accordance with CERCLA Section 121(d)(2)(B)(ii). The EPA maintains that ACLs should be used only when active restoration of the groundwater to MCLs or nonzero MCLGs is not practicable. The availability of institutional controls in itself is not sufficient reason to extend the allowance for levels above drinking water standards or nonzero goals; rather, institutional controls are considered as the sole remedy only where active remediation is not practicable. The EPA's policy for groundwater that is or may be used for drinking is as follows: if relevant and appropriate requirements exist (i.e., MCLs and MCLGs), a waiver is generally needed for cases in which they cannot be attained. However, if a situation fulfills the criteria for ACLs, including a finding that active restoration of the groundwater to MCLs or nonzero MCLGs is deemed not to be practicable, documentation of these conditions for the ACL is sufficient, and additional documentation of a waiver of the MCL or MCLG is not necessary.

The ACLs may be established where remediation of the groundwater is not practicable. The EPA Directive 9283.1-2FS, "A Guide on Remedial Actions for Contaminated Ground Water," sets out factors that may cause active restoration to be impracticable or not cost-effective, including the following:

- Widespread plumes such as industrial areas, mining sites, and pesticide sites;

- Hydrogeological constraints such as fractured bedrock or a transmissivity of less than $4.6 \mathrm{~m}^{2} / \mathrm{d}\left(50 \mathrm{ft}^{2} / \mathrm{d}\right)$;

- Contaminant-related factors such as the presence of dense, nonaqueous-phase liquids; and

- Physical/chemical factors such as partitioning to soil or organic matter.

However, CERCLA 121(d)(20)(B)(ii) restricts the use of ACLs to groundwater that discharges to nearby surface water and causes no statistically significant increase in contaminants in the surface water. In addition, provision must be made for enforceable institutional controls that prevent access to the contaminant plume.

Another provision of the preamble of the NCP states that the EPA agrees that meeting the: conditions and requirements associated with a variance or exemption provision can be a means of: compliance with an ARAR. Subpart B of 40 CFR 192 on Standards for Cleanup of Land and. 
Buildings Contaminated with Residual Radioactive Materials from Inactive Uranium Processing Sites provides for ACLs if DOE has determined that the constituent will not pose a substantial present or potential hazard to human health and the environment as long as the ACL is not exceeded and the U.S. Nuclear Regulatory Commission has concurred (40 CFR 192.12). In considering the present or potential hazard to human health and the environment of ACLs, the following factors shall be considered:

1. Potential adverse effects on groundwater quality, considering:

(i) The physical and chemical characteristics of constituents in the residual radioactive material at the site, including their potential for migration;

(ii) The hydrogeological characteristics of the site and surrounding land;

(iii) The quantity of groundwater and the direction of groundwater flow;

(iv) The proximity and withdrawal rates of groundwater users;

(v) The current and future uses of groundwater in the region surrounding the site;

(vi) The existing quality of groundwater, including other sources of contamination and their cumulative impact on the groundwater quality;

(vii) The potential for health risks caused by human exposure to constituents;

(viii) The potential damage to wildlife, crops, vegetation, and physical structures caused by exposure to constituents;

(ix) The persistence and permanence of the potential adverse effects; and

(x) The presence of underground sources of drinking water and exempted aquifers identified under 40 CFR 144.7 .

2. Potential adverse effects on hydraulically connected surface water quality, considering:

(i) The volume and physical and chemical characteristics of the residual radioactive material at the site;

(ii) The hydrogeological characteristics of the site and surrounding land; 
(iii) The quantity and quality of groundwater, and the direction of groundwater flow;

(iv) The patterns of rainfall in the region;

(v) The proximity of the site to surface waters;

(vi) The current and future uses of surface waters in the region surrounding the site and any water quality standards established for those surface waters;

(vii) The existing quality of surface water, including other sources of contamination and their cumulative impact on surface water quality;

(viii) The potential for health risks caused by human exposure to constituents;

(ix) The potential damage to wildlife, crops, vegetation, and physical structures caused by exposure to constituents; and

(x) The persistence and permanence of the potential adverse effects.

Therefore, if after consideration of these factors, it appears that the criteria for establishing an ACL. are met, the ACL is established as the ARAR.

In addition, these regulations for addressing contaminated groundwater at inactive uranium processing sites also provide for supplemental standards when one or more of the following criteria apply (40 CFR 192.21):

1. Remedial actions would pose a clear and present risk of injury to workers or to members of the public;

2. Remedial actions would, notwithstanding reasonable measures to limit damage, directly produce health and environmental harm that is clearly excessive compared to the health and environmental benefits, now or in the future:

3. The estimated cost at a "vicinity" site is unreasonably high relative to the long-term benefits, and the residual radioactive materials do not pose a clear present or future hazard;

4. There is no known remedial action; 
5. The restoration of groundwater quality is technically impracticable from an engineering perspective; or

6. The groundwater is not a current or potential source of drinking water (based on concentrations of total dissolved solids, widespread, ambient contamination or the quantity of water reasonably available (40 CFR 192.11(e)).

If these criteria are met, a supplemental standard established in accordance with the regulation (40 CFR 192.22) would become the ARAR.

The point of compliance for groundwater cleanup standards is at appropriate locations in the groundwater (40 CFR 300.430(f)(5)(iii)(A)). The EPA believes that remediation levels should generally be attained either throughout the contaminated plume or at and beyond the edge of the waste management area when the waste is left in place. However, the EPA acknowledges that an alternative point of compliance may also be protective of human health and the environment under site-specific circumstances. In determining where to draw the point of compliance in such situations, the lead agency will consider factors such as proximity of the sources, technical practicability of groundwater remediation at that specific site, vulnerability of the groundwater and its possible uses, exposure and likelihood of exposure, and similar considerations.

Under the NCP, ARARs must be met during the course of the remedial action (40 CFR 300.435(b)(2)). However, in the preamble to the NCP, the EPA clarified that it recognized that ARARs used to determine final remediation levels (e.g., MCLs for groundwater remediation) apply only at the completion of the action (55 FR 8755; March 8, 1990). In addition, CERCLA provides a waiver from ARARs for interim actions, provided that the final action will attain the waived standard. If there is doubt about whether an ARAR represents a final remediation goal or an interim standard, and the ARAR cannot be met during the activity, this waiver could be invoked. Groundwater contaminant-specific ARARs for the alternatives analyzed in detail in this FS are final remediation levels and should have to be met only at the completion of the remediation period.

An alternative that does not meet an ARAR under federal environmental or state environmental or facility siting laws may be selected under five waiver circumstances (40 CFR 300.430(f)(1)(ii)(C)). (A sixth waiver is available to Superfund-financed sites, which would not be applicable to the Weldon Spring site.) These five relevant waiver circumstances are as follows:

1. The alternative is an interim measure and will become part of a total remedial action that will attain the ARAR; 
2. Compliance with the requirement will result in greater risk to human health and the environment than other alternatives;

3. Compliance with the requirement is technically impracticable from an engineering perspective;

4. The alternative will attain a standard of performance that is equivalent to that required under the otherwise applicable standard, requirement, or limitation through use of another method or approach; or

5. With respect to a state requirement, the state has not consistently applied, or demonstrated the intention to consistently apply, the promulgated requirement in similar circumstances at other remedial actions within the state.

The interim measure waiver requires that the (1) interim measure should be followed within a reasonable time by complete measures that will attain ARARs and (2) the interim measure should not exacerbate site problems nor interfere with the final remedy. In the preamble to the NCP, the EPA, in response to comments, declined setting a specific time limit as a precondition for invoking this waiver because it is difficult to predict exactly when complete measures can be undertaken, given changes in funding, priorities, and other factors. The EPA believes that careful risk assessments may be used to show that greater risks will result from compliance with ARARs and that a waiver may be appropriate. However, the alternative to which compliance with an ARAR is compared is not limited to a "no action" alternative, but may be a less active measure (e.g., excavation compared with capping).

To obtain a waiver for technical impracticability, the EPA believes that criteria may include engineering feasibility and reliability, and that cost is generally not a major factor unless compliance would be inordinately costly. The EPA believes that cost should generally play a subordinate role in determining practicability from an engineering perspective, and states that "engineering practice is in reality ultimately limited by costs, hence cost may legitimately be considered in determining, what is ultimately practicable" ( 55 FR 8748; March 8, 1990). The proposed criteria waiving an ARAR in lieu of an equivalent standard of performance include degree of protection, level of: performance, reliability into the future, and time required for results. In the preamble to the final $\mathrm{NCP}$, the EPA states its belief that the first three criteria should be at least equal for an alternative to be considered equivalent. In addition, the time required to achieve results using the alternative: remedy should not be significantly more than that required under the waived ARAR. The EPA stated that the fourth criterion proposed "was not specific precisely in order to allow cases in which alternative methods may provide great benefits even though requiring longer time for implementation, as with, for example, the use of bioremediation instead of incineration" (55 FR 8749; March 8, 1990). The last waiver is intended simply to prevent application of state: requirements to Superfund sites that have not been consistently applied elsewhere in the state. 


\section{A.2 PRELIMINARY EVALUATION OF REQUIREMENTS}

Requirements of federal and state laws that might be considered applicable or relevant and appropriate to the proposed remedial alternatives considered for detailed analysis in this FS are listed in Table A.1. Potential TBC requirements are also included in the table. In addition, the table includes certain requirements that are part of employee protection laws or other nonenvironmental laws with which the CERCLA actions may have to comply and which are, therefore, not subject to the ARAR evaluation process for attainment or waiver. These requirements have simply been included as TBCs.

The preliminary ARAR and TBC determinations for these requirements are indicated in Table A.1. Because this appendix presents a comprehensive list of requirements, all determinations have been identified as "potentially" applicable, relevant and appropriate, or to-be-considered. These determinations will be finalized in consultation with the State of Missouri and EPA Region VII before the selected remedial action is implemented. During the finalization process, the requirements identified as potentially applicable will be reviewed to confirm direct applicability; only one requirement will be finalized from among those that regulate the same conditions or media. For those requirements identified as potentially relevant and appropriate and TBC requirements, the specific portions of the requirement that have bearing on the action, and the manner in which compliance would be achieved, will be finalized.

\section{A.3 REFERENCE FOR APPENDIX A}

Browner, C.M., 1995, letter from C.M. Browner (Administrator, U.S. Environmental Protection Agency) to D.A. Shorr (Director, Missouri Department of Natural Resources) re: In the matter of the Former Weldon Spring Ordnance Works, Nov. 1, 1995. 
TABLE A.1 Quarry Residuals Operable Unit ARARs

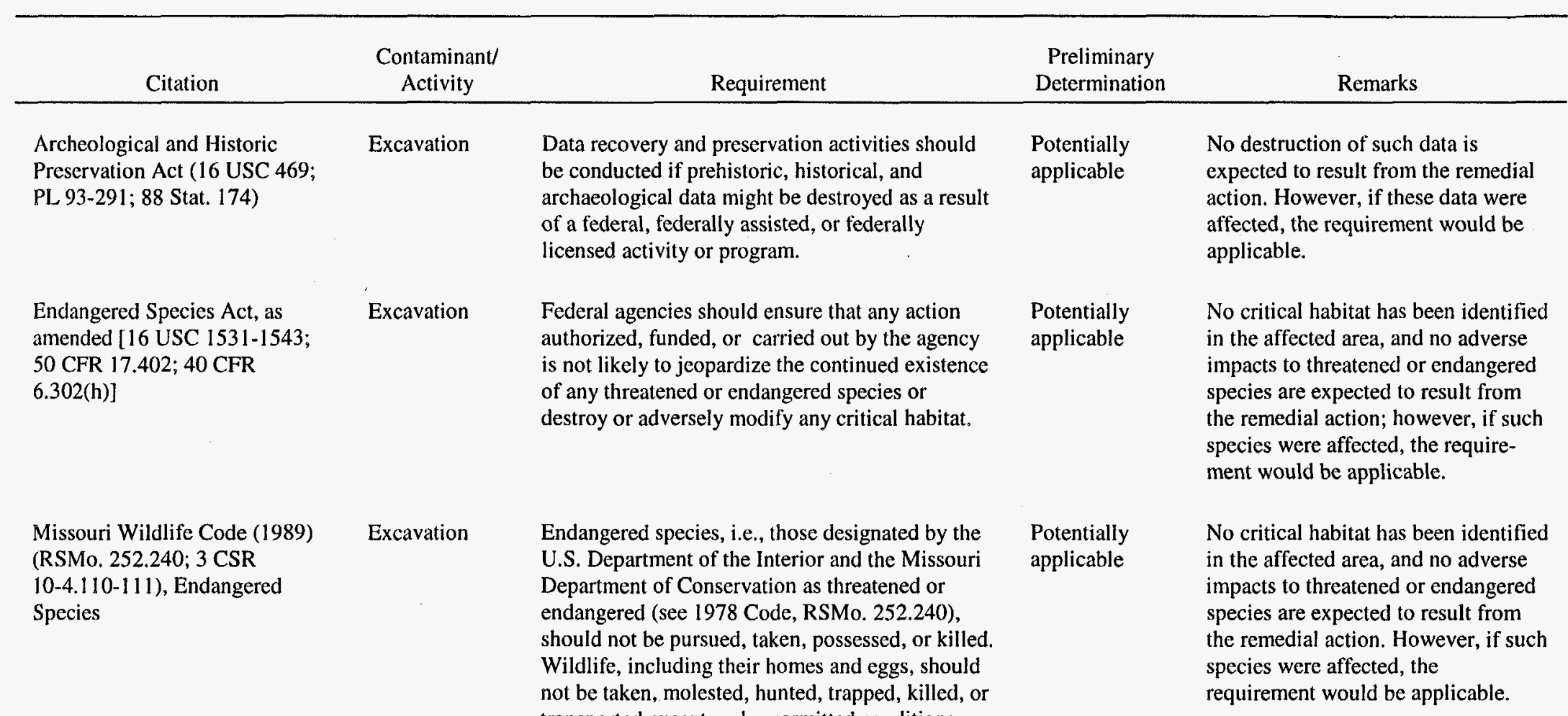
transported except under permitted conditions. 
TABLE A.1 (Cont.)

\begin{tabular}{|c|c|c|c|c|}
\hline Citation & $\begin{array}{c}\text { Contaminant/ } \\
\text { Activity }\end{array}$ & Requirement & $\begin{array}{l}\text { Preliminary } \\
\text { Determination }\end{array}$ & Remarks \\
\hline $\begin{array}{l}\text { Groundwater Standards for } \\
\text { Remedial Actions at Inactive } \\
\text { Uranium Processing Sites } \\
\text { (40 CFR 192.02) }\end{array}$ & Uranium & $\begin{array}{l}\text { Concentration limits in groundwater must not } \\
\text { exceed the background level of that constituent in } \\
\text { the groundwater or } 30 \mathrm{pCi} / \mathrm{L} \text { for uranium- } 234 \text { and } \\
\text { uranium- } 238 \text { combined (where there is secular } \\
\text { equilibrium, this criterion is satisfied by a } \\
\text { concentration of } 0.044 \mathrm{mg} / \mathrm{L} \text {; for conditions other } \\
\text { than secular equilibrium, a corresponding value } \\
\text { may be derived, on the basis of the measured site- } \\
\text { specific ratio of the two isotopes of uranium); or } \\
\text { an alternative concentration limit set by the } \\
\text { U.S. Nuclear Regulatory Commission, which has } \\
\text { determined that the constituent will not pose a } \\
\text { substantial present or potential future hazard to } \\
\text { human health and the environment, on the basis } \\
\text { of potential adverse effects on groundwater } \\
\text { quality and potential adverse effects on } \\
\text { hydraulically connected surface water quality. }\end{array}$ & $\begin{array}{l}\text { Potentially } \\
\text { relevant but } \\
\text { not appropriate }\end{array}$ & $\begin{array}{l}\text { This regulation is not applicable } \\
\text { because the Weldon Spring site is } \\
\text { not an inactive uranium processing } \\
\text { site regulated under } 40 \text { CFR } \\
\text { Part } 192 \text {. However, because no MCL } \\
\text { or MCLG exists for uranium under } \\
\text { the SDWA, this regulation is } \\
\text { potentially relevant to the cleanup } \\
\text { levels proposed for groundwater. } \\
\text { However, this standard was } \\
\text { developed for sites generally located } \\
\text { in arid regions of the western United } \\
\text { States where water is a scarce } \\
\text { resource. As such, this standard is } \\
\text { not considered to be well suited to } \\
\text { conditions at the quarry area. }\end{array}$ \\
\hline
\end{tabular}

Safe Drinking Water Act; National Primary Drinking

Water Regulations; Maximum Contaminant Levels (40 CFR 141.11 and 141.62); Missouri Drinking Water Regulations,

Maximum Inorganic Chemical

Contaminant Levels

(10 CSR 60-4.030)

\section{Organic and \\ inorganic}

contaminants
Potentially relevant and appropriate
These regulations are not applicable because MCLs are applicable only to drinking water at the tap, not in ground water. However, under the NCP, MCLs are relevant and appropriate to groundwater that is a potential drinking water source. 
TABLE A.1 (Cont.)

\begin{tabular}{|c|c|c|c|c|}
\hline Citation & $\begin{array}{l}\text { Contaminant/ } \\
\text { Activity }\end{array}$ & Requirement & $\begin{array}{c}\text { Preliminary } \\
\text { Determination }\end{array}$ & Remarks \\
\hline \multirow[t]{3}{*}{$\begin{array}{l}\text { Missouri Water Quality } \\
\text { Standards [10 CSR 20-7.031(5) } \\
\text { and Table A] }\end{array}$} & \multirow[t]{3}{*}{$\begin{array}{l}\text { Groundwater } \\
\text { contaminants }\end{array}$} & $\begin{array}{l}\text { Water contaminants shall not cause or contribute } \\
\text { to exceedance of the following levels in aquifers. } \\
\text { These criteria apply in any part of the aquifer, } \\
\text { including the point at which the pollutant enters } \\
\text { the aquifer. Where potential uses are not } \\
\text { impaired, alternative site-specific criteria may be } \\
\text { allowed. Those values listed as health advisory } \\
\text { levels (as indicated below by an asterisk [*]) shall } \\
\text { be used in establishing groundwater cleanup } \\
\text { criteria until additional data become available to } \\
\text { support alternative criteria or other standards are } \\
\text { established. }\end{array}$ & \multirow[t]{3}{*}{$\begin{array}{l}\text { Potentially } \\
\text { applicable }\end{array}$} & \multirow[t]{3}{*}{$\begin{array}{l}\text { These water quality standards apply } \\
\text { to groundwater of the state, including } \\
\text { establishing groundwater cleanup } \\
\text { criteria. }\end{array}$} \\
\hline & & Contaminant & & \\
\hline & & $\begin{array}{ll}\text { Nitrobenzene } & 17 \mu \mathrm{g} / \mathrm{L} \\
\text { 2,4-Dinitrotoluene } & 0.11 \mu \mathrm{g} / \mathrm{L} \\
\text { 1,3-Dinitrobenzene } & 1.0 \mu \mathrm{g} / \mathrm{L}^{*} \\
\end{array}$ & & \\
\hline $\begin{array}{l}\text { Safe Drinking Water Act, } \\
\text { Proposed National Primary } \\
\text { Drinking Water Regulations } \\
\text { (40 CFR 141; 56 FR } 33050 \\
\text { [July 18, 1991]) }\end{array}$ & Radionuclides & $\begin{array}{l}\text { The MCL for uranium in drinking water is } \\
20 \mu \mathrm{g} / \mathrm{L}(20 \mu \mathrm{g} / \mathrm{L} \text { is approximately equal to } \\
14 \mathrm{pC} / \mathrm{L}) \text {, for conditions of secular equilibrium } \\
\text { between uranium- } 238 \text { and uranium- } 234 \text {, which is } \\
\text { applicable to groundwater conditions in the } \\
\text { quarry area. }\end{array}$ & Potential TBC & $\begin{array}{l}\text { Because this is a proposed } \\
\text { regulation, it cannot be applicable or } \\
\text { relevant and appropriate; however, it } \\
\text { may be considered in developing a } \\
\text { remediation level for uranium. }\end{array}$ \\
\hline
\end{tabular}


TABLE A.1 (Cont.)

Preliminary

Determination

Remarks

\begin{tabular}{|c|c|c|c|c|c|c|c|}
\hline Citation & $\begin{array}{l}\text { Contaminant/ } \\
\text { Activity }\end{array}$ & \multicolumn{6}{|c|}{ Requirement } \\
\hline \multirow{5}{*}{$\begin{array}{l}\text { Drinking Water Regulations } \\
\text { and Health Advisories } \\
\text { (EPA 822-R-93-001, } \\
\text { Office of Water, May 1995) }\end{array}$} & \multirow[t]{5}{*}{$\begin{array}{l}\text { Nitroaromatics } \\
\text { and uranium }\end{array}$} & \multicolumn{6}{|c|}{$\begin{array}{l}\text { Health advisory (reference dose [RfD]) and } \\
\text { drinking water equivalent levels (DWEL) for a } \\
70-\mathrm{kg} \text { adult have been set as follows: }\end{array}$} \\
\hline & & & Term & $\begin{array}{l}\mathrm{RfD} \\
(\mathrm{mg} / \\
\mathrm{kg} / \mathrm{d})\end{array}$ & $\begin{array}{l}\text { DWEL } \\
(\mathrm{mg} / \mathrm{L})\end{array}$ & $\begin{array}{c}\text { Lifetime } \\
(\mathrm{mg} / \mathrm{L})\end{array}$ & $\begin{array}{c}\mathrm{mg} / \mathrm{L} \\
\text { at } 10^{-4} \\
\text { Cancer Risk } \\
\end{array}$ \\
\hline & & 2,4-DNT & 1 & 0.002 & 0.1 & - & 0.005 \\
\hline & & 2,6-DNT & 1 & 0.001 & 0.04 & - & 0.005 \\
\hline & & Uranium & - & 0.003 & - & - & - \\
\hline \multirow[t]{4}{*}{$\begin{array}{l}\text { Radiation Protection of the } \\
\text { Public and the Environment } \\
\text { (DOE Order 5400.5) }\end{array}$} & Radionuclides & \multicolumn{6}{|c|}{$\begin{array}{l}\text { DOE Order } 5400.5 \text { establishes a maximum limit } \\
\text { for the annual dose to members of the public of } \\
100 \text { mrem ( } 1 \mathrm{mSv} \text { ) total effective dose equivalent } \\
\text { per year. All radiation exposures should be } \\
\text { reduced to levels as low as reasonably achievable } \\
\text { (ALARA). The derived concentration guide } \\
\text { (DCG) values that would result in } 100 \mathrm{mrem} / \mathrm{yr} \\
\text { for ingested water contaminated with uranium are } \\
\text { as follows: }\end{array}$} \\
\hline & & \multicolumn{3}{|c|}{ Radionuclide $^{\mathrm{a}}$} & \multicolumn{3}{|c|}{ DCG } \\
\hline & & \multicolumn{3}{|c|}{$\begin{array}{l}\text { Uranium }-234 \\
f_{1} \text { value }=0.05 \\
f_{1} \text { value }=0.002\end{array}$} & & $\begin{array}{l}5 \times 10^{-7} \\
5 \times 10^{-6}\end{array}$ & \\
\hline & & \multicolumn{3}{|c|}{$\begin{array}{l}\text { Uranium }-238 \\
f_{1} \text { value }=0.05 \\
f_{1} \text { value }=0.002\end{array}$} & & $\begin{array}{l}6 \times 10^{-7} \\
6 \times 10^{-6}\end{array}$ & \\
\hline
\end{tabular}

rinking Water Regulations EPA 822-R-93-001,

Office of Water, May 1995)

Public and the Environment

a $\mathrm{f}_{1}$ represents the fractional uptake from the small intestine to blood.

Potential TBC

These values are not regulations but may be used in the absence of regulatory limits for developing groundwater remediation levels.

Potential TBC

Orders are internal standards and requirements for the operation of DOE facilities, they are not ARARs; however, they may be

considered in developing

remediation level for uranium 
TABLE A.1 (Cont.)

\begin{tabular}{|c|c|c|c|c|}
\hline Citation & $\begin{array}{l}\text { Contaminant/ } \\
\text { Activity }\end{array}$ & Requirement & $\begin{array}{c}\text { Preliminary } \\
\text { Determination }\end{array}$ & Remarks \\
\hline $\begin{array}{l}\text { Missouri Radiation Regulations; } \\
\text { Protection Against lonizing } \\
\text { Radiation (19 CSR 20-10.040), } \\
\text { Maximum Permissible Exposure } \\
\text { Limits }\end{array}$ & Radiation & $\begin{array}{l}\text { For persons outside a controlled area, the } \\
\text { maximum permissible whole-body doses due to } \\
\text { sources in or migrating from the controlled area } \\
\text { are limited to } 2 \text { mrem in any } 1 \text { hour, } 0.1 \text { rem in } \\
\text { any } 7 \text { consecutive days, and } 0.5 \text { rem in any } \\
1 \text { year. (Note: a controlled area is an area that } \\
\text { requires control of access, occupancy, and }\end{array}$ & Potential TBC & $\begin{array}{l}\text { These requirements are part of an } \\
\text { employee protection law (rather than } \\
\text { an environmental law) and, therefore, } \\
\text { cannot be ARARs. However, they } \\
\text { may provide guidance in determining } \\
\text { a remediation level for uncontrolled } \\
\text { areas. }\end{array}$ \\
\hline
\end{tabular}

Health and Environmental Protection Standards for Uranium and Thorium Mill Tailings (40 CFR 192), Subpart D, Standards for Management of Uranium

Byproduct Materials Pursuant to Section 84 of the Atomic Energy Act of 1954, as amended; Subpart E, Standards for Management of Thorium Byproduct Materials Pursuant to Section 84 of the Atomic Energy Act of 1954 , as amended.

Radiation Protection of the Public and the Environment (DOE Order 5400.5)
Radiation working conditions for radiation protection purposes; $0.5 \mathrm{rem}=500 \mathrm{mrem}$.)

Processing operations during and prior to the end of the closure period at a facility managing uranium and thorium by-product materials should be conducted in a manner that provides reasonable assurance that the annual dose equivalent does not exceed 25 mrem to the whole body, 75 mrem to the thyroid, and $25 \mathrm{mrem}$ to any other organ of any member of the public as a result of exposures to the planned discharge of radioactive material to the general environment (excluding radon-222, radon-220, and their decay products).

The concentration of radionuclides in liquid wastes discharged to natural waterways should be reduced to levels ensuring that the absorbed dose to native aquatic animal organisms does not exceed $1 \mathrm{rad} / \mathrm{d}$.
Potentially relevant and appropriate

To be considered
These requirements would not be applicable because the remedial action does not constitute a processing operation, nor does it include a planned discharge of radioactive material to the environment. Nevertheless, the requirements could be considered relevant and appropriate to protection of the public during implementation of the action because the waste type and the potential release issue could be considered sufficiently similar.

Although not a promulgated standard, this requirement provides protection for aquatic organisms from liquid discharges with which the remedial action would comply. 
TABLE A.1 (Cont.)

\begin{tabular}{ccc}
\hline & Contaminant/ & Preliminary \\
Activity & Requirement & Determination \\
\hline
\end{tabular}

Missouri Construction and Wastewater A wastewater treatment plant must be constructed

Operating Permit Regulations discharge and operated in accordance with a state-approved (10 CSR 20-6.010)

engineering report and detailed plans and specifications so as to meet the state-specified

contaminant release concentrations and/or

weights in compliance with the Missouri Clean

Water Law.

Potentially

applicable

Pursuant to CERCLA $\$ 121$ (e), no

permit is required for on-site

activities; however, substantive

permit conditions such as

construction, engineering, and operating requirements for the treatment facility would be applicable to any wastewater treatment facility constructed on-site, or in very close proximity to the contamination, as part of a remedial action. If the wastewater is to be treated in the existing on-site treatment plant, and the discharge would violate existing effluent limitations in place for the plant, modification of the existing operation or discharge conditions may be necessary.

Well

construction

Groundwater Quality and

Resources (10 CSR 23-4.050)

Missouri Stormwater Discharge

Regulations [10 CSR

20-6.010(13)
Stormwater discharges
All monitoring wells must be constructed in accordance with the rules (10 CSR 23-4.060), and an annular space must be sealed. When no longer in service, monitoring wells must be properly plugged. New off-site monitoring wells must be constructed by licensed monitoring well diggers, pursuant to a well permit, and the construction must be reported to the Division, for review via a certification report form.

Missouri has issued stormwater general permits for discharges associated with land disturbance activities. The general permits contain general conditions, effluent limitations, and a requirement for the development of Stormwater Pollution Prevention Plans to prevent construction site runoff from polluting surface waters of the state.
Potentially applicable

Potentially applicable

the remedial action involves land disturbance activities, the substantive portions of the Missouri stormwater general permit would be applicable, unless the activities are exempted under the permit (i.e., insufficient acreage).

Pursuant to CERCLA $\$ 121(\mathrm{e})$, no permit is required for on-site well construction; however, substantive permit conditions for the construction of the wells would be applicable. 
TABLE A.1 (Cont.)

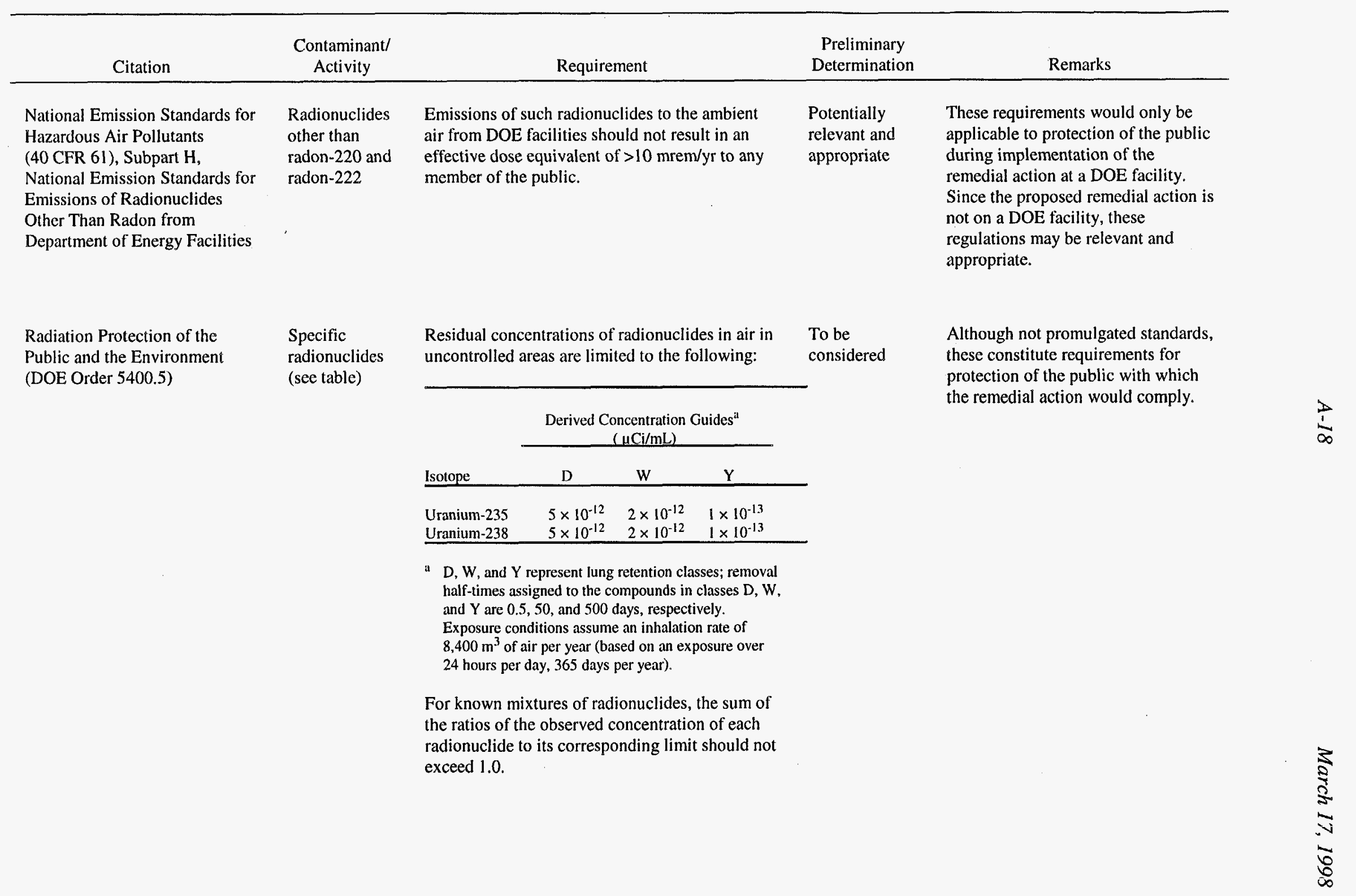


TABLE A.1 (Cont.)

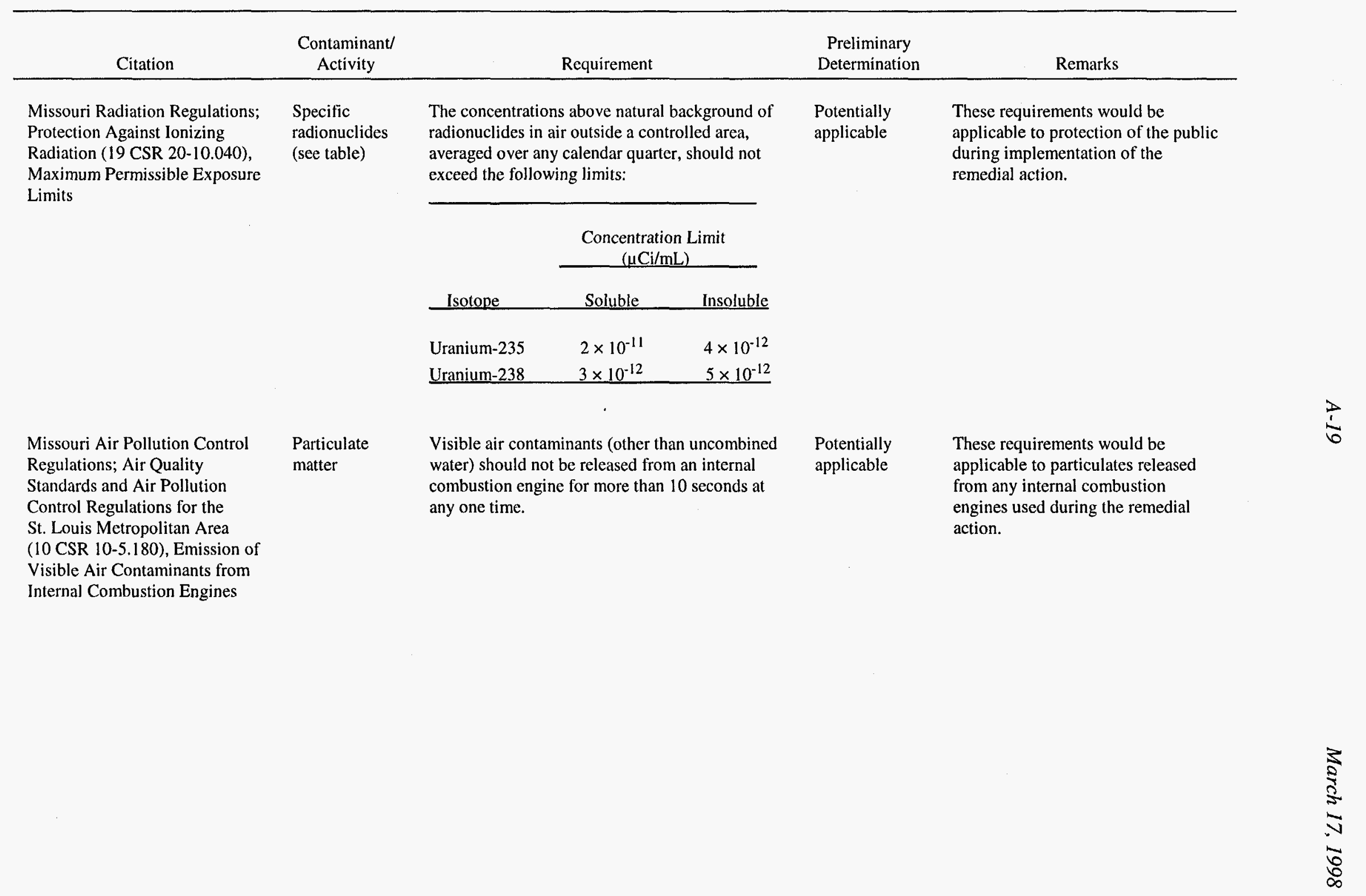


TABLE A.1 (Cont.)

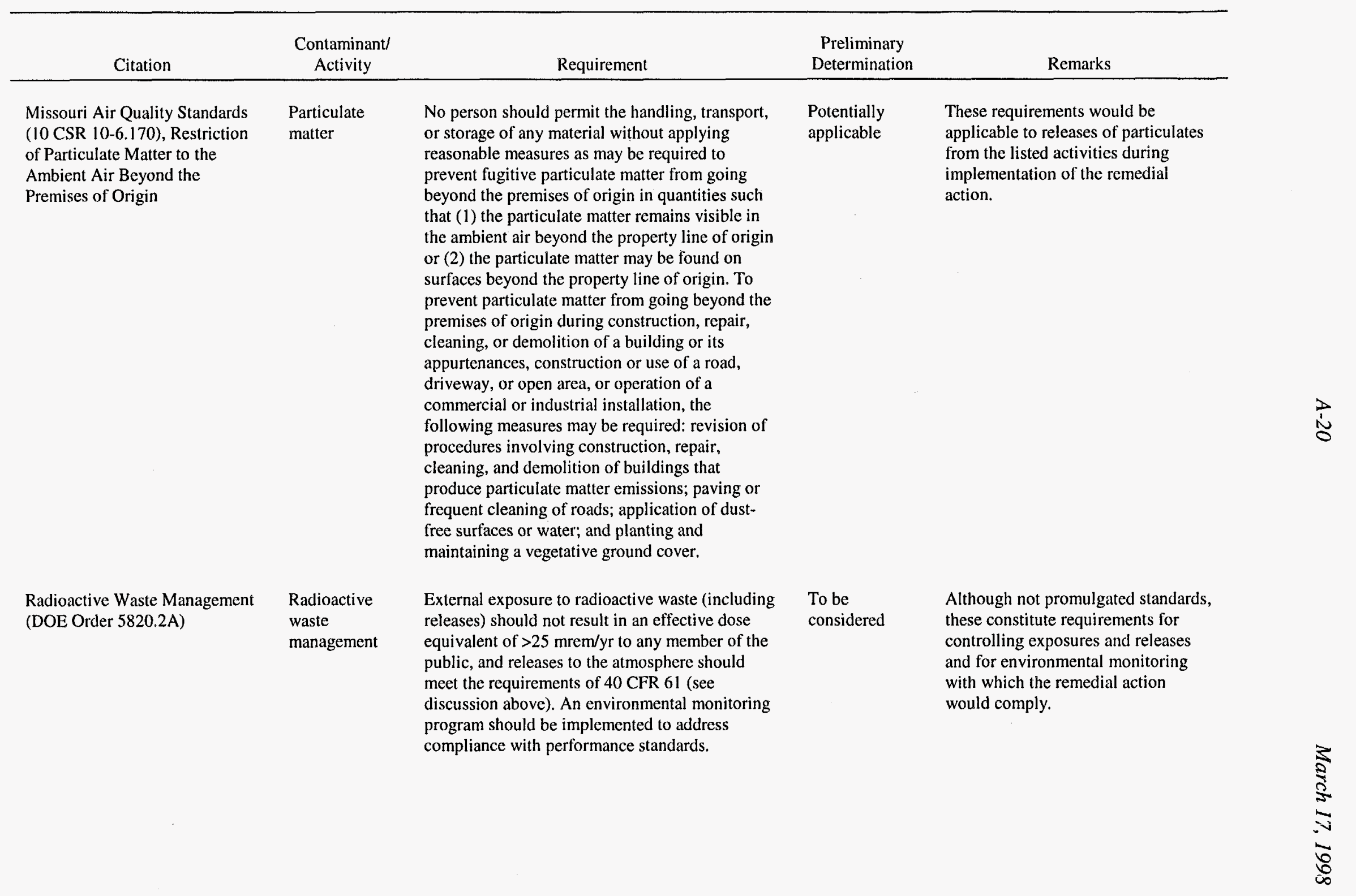


TABLE A.1 (Cont.)

\begin{tabular}{|c|c|c|c|c|}
\hline Citation & $\begin{array}{c}\text { Contaminant/ } \\
\text { Activity }\end{array}$ & Requirement & $\begin{array}{c}\text { Preliminary } \\
\text { Determination }\end{array}$ & Remarks \\
\hline $\begin{array}{l}\text { Missouri Radiation Regulations; } \\
\text { Protection Against lonizing } \\
\text { Radiation (19 CSR 20-10.070), } \\
\text { Storage of Radioactive Materials }\end{array}$ & $\begin{array}{l}\text { Radioactive } \\
\text { waste storage }\end{array}$ & $\begin{array}{l}\text { Radioactive materials should be stored in a } \\
\text { manner that will not result in the exposure of any } \\
\text { person during routine access to a controlled area, } \\
\text { in excess of the limits identified in } 19 \text { CSR } \\
20-10.040 \text { (see related discussion for } \\
\text { contaminant-specific requirements). A facility } \\
\text { used to store materials that may emit radioactive } \\
\text { gases or airborne particulate matter should be } \\
\text { vented to ensure that the concentration of such } \\
\text { substances in air does not constitute a radiation } \\
\text { hazard; and provisions should be made to } \\
\text { minimize the hazard to emergency workers in the } \\
\text { event of a fire, earthquake, flood, or windstorm. }\end{array}$ & $\begin{array}{l}\text { Potentially } \\
\text { applicable }\end{array}$ & $\begin{array}{l}\text { These requirements would be } \\
\text { applicable to the temporary storage } \\
\text { of certain material that would be } \\
\text { generated during the remedial action, } \\
\text { pending the availability of a disposal } \\
\text { facility. }\end{array}$ \\
\hline $\begin{array}{l}\text { Missouri Radiation Regulations; } \\
\text { Protection Against Ionizing } \\
\text { Radiation (19 CSR 20-10.080), } \\
\text { Control of Radioactive } \\
\text { Contamination }\end{array}$ & $\begin{array}{l}\text { Radioactive } \\
\text { waste manage- } \\
\text { ment }\end{array}$ & $\begin{array}{l}\text { All work should be carried out under conditions } \\
\text { that minimize the potential spread of radioactive } \\
\text { material that could result in the exposure of any } \\
\text { person above any limit specified in } 19 \text { CSR } \\
20-10.040 \text { (see related discussion for } \\
\text { contaminant-specific requirements). Clothing and } \\
\text { other personal contamination should be } \\
\text { monitored and removed according to procedures } \\
\text { established by a qualified expert; any material } \\
\text { contaminated to the degree that a person could be } \\
\text { exposed to radiation above any limit specified in } \\
19 \text { CSR } 20-10.040 \text { should be retained on-site } \\
\text { until it can be decontaminated or disposed of } \\
\text { according to procedures established by a qualified } \\
\text { expert. }\end{array}$ & Not an ARAR & $\begin{array}{l}\text { These requirements are part of an } \\
\text { employee protection law (rather than } \\
\text { an environmental law) with which } \\
\text { CERCLA response actions should } \\
\text { comply; hence, they are not subject } \\
\text { to the ARAR process. However, they } \\
\text { constitute requirements for worker } \\
\text { protection with which the proposed } \\
\text { action would comply. }\end{array}$ \\
\hline
\end{tabular}


TABLE A.1 (Cont.)

\begin{tabular}{|c|c|c|c|c|}
\hline Citation & $\begin{array}{l}\text { Contaminant/ } \\
\text { Activity }\end{array}$ & Requirement & $\begin{array}{c}\text { Preliminary } \\
\text { Determination }\end{array}$ & Remarks \\
\hline $\begin{array}{l}\text { Atomic Energy Act, as amended } \\
\text { (42 USC 2112) }\end{array}$ & $\begin{array}{l}\text { Radioactive } \\
\text { waste disposal }\end{array}$ & $\begin{array}{l}\text { The DOE can distribute by-product material only } \\
\text { to individuals or organizations who are licensed } \\
\text { by the NRC to receive such material. }\end{array}$ & $\begin{array}{l}\text { Potentially } \\
\text { applicable }\end{array}$ & $\begin{array}{l}\text { These requirements would be } \\
\text { applicable if the disposal of } \\
\text { radioactively contaminated (by- } \\
\text { product) material from the Weldon } \\
\text { Spring site would take place at a } \\
\text { commercial facility (e.g., the } \\
\text { Envirocare site near Clive, Utah). }\end{array}$ \\
\hline $\begin{array}{l}\text { Missouri Radiation Regulations; } \\
\text { Protection Against Ionizing } \\
\text { Radiation (19 CSR 20-10.090), } \\
\text { Disposal of Radioactive Wastes }\end{array}$ & $\begin{array}{l}\text { Radioactive } \\
\text { waste disposal }\end{array}$ & $\begin{array}{l}\text { Radioactive waste material should not be } \\
\text { disposed of by dumping or burial in soil, except } \\
\text { at sites approved by and registered with the } \\
\text { Missouri Department of Health; a permit should } \\
\text { be obtained for holding and preparation of such } \\
\text { material prior to disposal; and no releases to air or }\end{array}$ & $\begin{array}{l}\text { Potentially } \\
\text { applicable }\end{array}$ & $\begin{array}{l}\text { Radioactive waste from excavation } \\
\text { or water treatment activities would } \\
\text { be disposed of to the on-site, } \\
\text { approved cell or to a properly } \\
\text { licensed off-site commercial disposal } \\
\text { facility. }\end{array}$ \\
\hline
\end{tabular}
water should cause exposure to any person above the limits specified in 19 CSR 20-10.041 (see related discussion for contaminant-specific requirements). 
TABLE A.1 (Cont.)

\begin{tabular}{|c|c|c|c|c|c|c|}
\hline Citation & $\begin{array}{c}\text { Contaminant/ } \\
\text { Activity }\end{array}$ & & Requirement & & $\begin{array}{c}\text { Preliminary } \\
\text { Determination }\end{array}$ & Remarks \\
\hline \multirow{5}{*}{$\begin{array}{l}\text { Missouri Radiation Regulations; } \\
\text { Protection Against Ionizing } \\
\text { Radiation (19 CSR 20-10.040), } \\
\text { Maximum Permissible Exposure } \\
\text { Limits }\end{array}$} & \multirow[t]{5}{*}{ Radiation } & $\begin{array}{l}\text { Limits for occup } \\
\text { radiation in a co }\end{array}$ & $\begin{array}{l}\text { tional doses fron } \\
\text { rolled area are a }\end{array}$ & $\begin{array}{l}m \text { ionizing } \\
\text { as follows: }\end{array}$ & \multirow[t]{4}{*}{ Not an ARAR } & \multirow{5}{*}{$\begin{array}{l}\text { These requirements are part of an } \\
\text { employee protection law (rather than } \\
\text { an environmental law) with which } \\
\text { CERCLA response actions should } \\
\text { comply; hence, they are not subject } \\
\text { to the ARAR process. They are } \\
\text { indicated in this table to identify } \\
\text { requirements for worker protection } \\
\text { with which the remedial action } \\
\text { would comply. }\end{array}$} \\
\hline & & Part of Body & $\begin{array}{l}\text { Maximum Dose } \\
\text { in Any } \\
\text { Calendar Year } \\
\text { (rem) } \\
\end{array}$ & $\begin{array}{l}\text { Maximum Dose } \\
\text { in Any } \\
\text { Calendar Quarter } \\
\text { (rem) }\end{array}$ & & \\
\hline & & $\begin{array}{l}\text { Whole body, head } \\
\text { and trunk, major } \\
\text { portion of bone } \\
\text { marrow, gonads, } \\
\text { or lens of eye }\end{array}$ & 5 & 3 & & \\
\hline & & $\begin{array}{l}\text { Hands and fore- } \\
\text { arms, feet and } \\
\text { ankles }\end{array}$ & 75 & 25 & & \\
\hline & & $\begin{array}{l}\text { Skin of large } \\
\text { body area }\end{array}$ & 30 & 10 & & \\
\hline
\end{tabular}

Also, the whole-body dose added to the

cumulative occupational dose should not exceed $5(\mathrm{~N}-18)$ rem, where $\mathrm{N}$ is the age of the exposed individual.

Occupational exposure to airborne radioactive material, averaged over any calendar quarter, should not exceed the following limits:

\begin{tabular}{llr}
\hline & \multicolumn{2}{c}{$\begin{array}{c}\text { Concentration Limit } \\
(\mu \mathrm{Ci} / \mathrm{mL})\end{array}$} \\
\cline { 2 - 3 } Isotope & Soluble & Insoluble \\
\hline Uranium-235 & $5 \times 10^{-10}$ & $1 \times 10^{-10}$ \\
Uranium-238 & $7 \times 10^{-11}$ & $1 \times 10^{-10}$ \\
\hline
\end{tabular}


TABLE A.1 (Cont.)

\begin{tabular}{|c|c|c|c|c|}
\hline Citation & $\begin{array}{l}\text { Contaminant/ } \\
\text { Activity }\end{array}$ & Requirement & $\begin{array}{c}\text { Preliminary } \\
\text { Determination }\end{array}$ & Remarks \\
\hline $\begin{array}{l}\text { Missouri Radiation Regulations; } \\
\text { Protection Against Ionizing } \\
\text { Radiation (19 CSR 20-10.050), } \\
\text { Personnel Monitoring and } \\
\text { Radiation Surveys }\end{array}$ & Radiation & $\begin{array}{l}\text { Personal monitoring and radiation surveys are } \\
\text { required for each worker for whom there is any } \\
\text { reasonable possibility of receiving a weekly dose } \\
\text { from all radiation exceeding } 50 \text { mrem, taking into } \\
\text { consideration the use of protective gloves and } \\
\text { radiation-limiting devices. An exemption from } \\
\text { routine monitoring may be granted under certain } \\
\text { conditions. }\end{array}$ & Not an ARAR & $\begin{array}{l}\text { These requirements are part of an } \\
\text { employee protection law (rather than } \\
\text { an environmental law) with which } \\
\text { CERCLA response actions should } \\
\text { comply; hence, they are not subject } \\
\text { to the ARAR process. They are } \\
\text { indicated in this table to identify } \\
\text { requirements for worker protection } \\
\text { with which the remedial action } \\
\text { would comply. }\end{array}$ \\
\hline
\end{tabular}

Occupational Safety and Health Radiation Administration Standards;

Occupational Health and

Environmental Control (29 CFR

1910; 1910.96), Subpart G,

Ionizing Radiation
The dose per calendar quarter resulting from exposure to radiation in a restricted area from sources in that area is limited to the following:

\begin{tabular}{cc}
\hline & Dose \\
Part of Body & (rem) \\
\hline
\end{tabular}

Whole body, head and trunk, active blood-forming organs, lens of eye, or gonads

Hands and forearms, feet and ankles

Skin of whole body 7.5

The occupational exposure of an individual younger than 18 is restricted to $10 \%$ of these limits; the whole-body dose to a worker may not exceed 3 rem in a calendar quarter and, when added to the cumulative occupational dose, should not exceed $5(\mathrm{~N}-18)$ rem, where $N$ is the age of the exposed individual.
Not an ARAR

These requirements are part of an employee protection law (rather than an environmental law) with which CERCLA response actions should comply. Therefore, these

requirements are not subject to the ARAR evaluation process for attainment or waiver. They are indicated in this table to identify requirements for worker protection with which the remedial action would comply. 


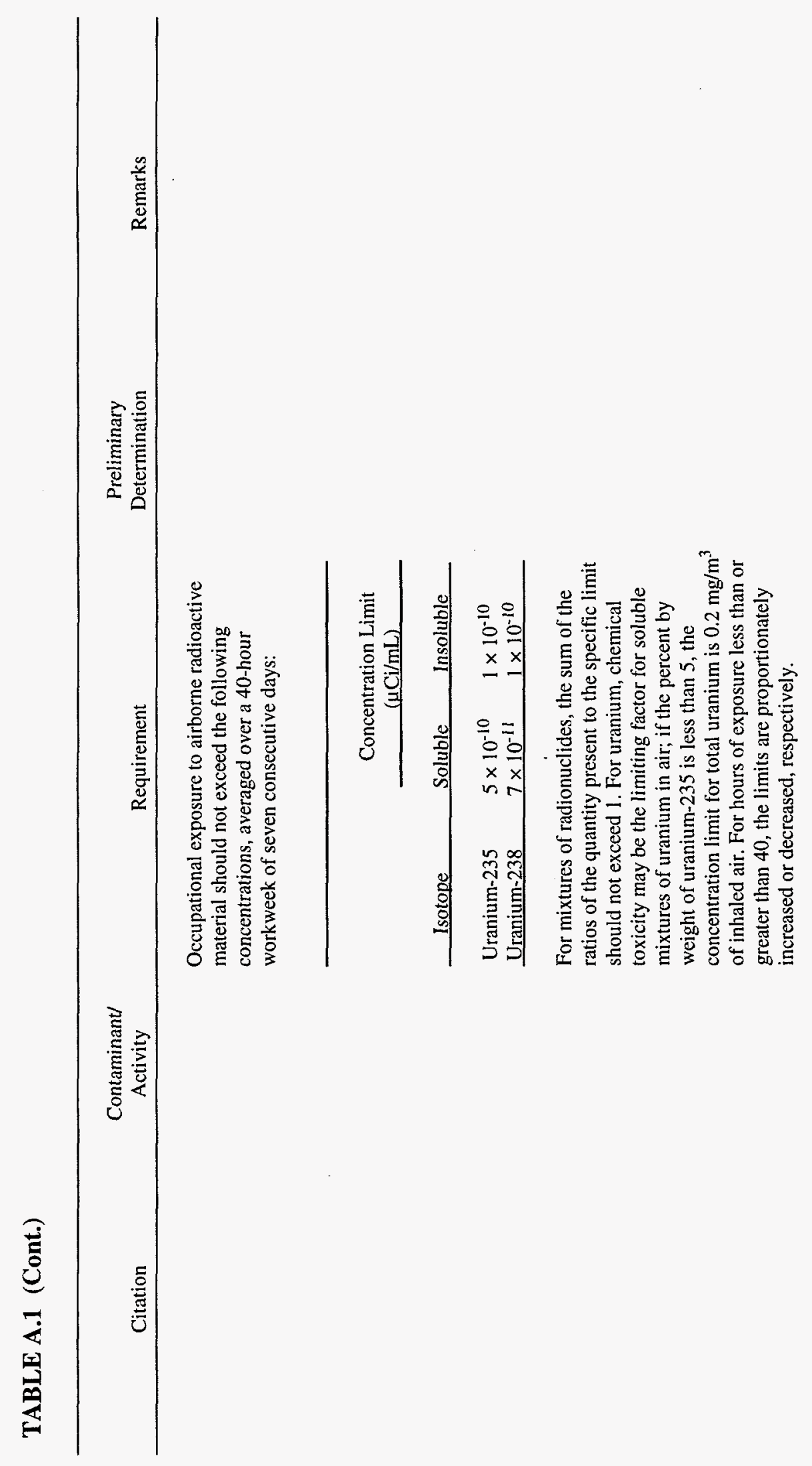


TABLE A.1 (Cont.)

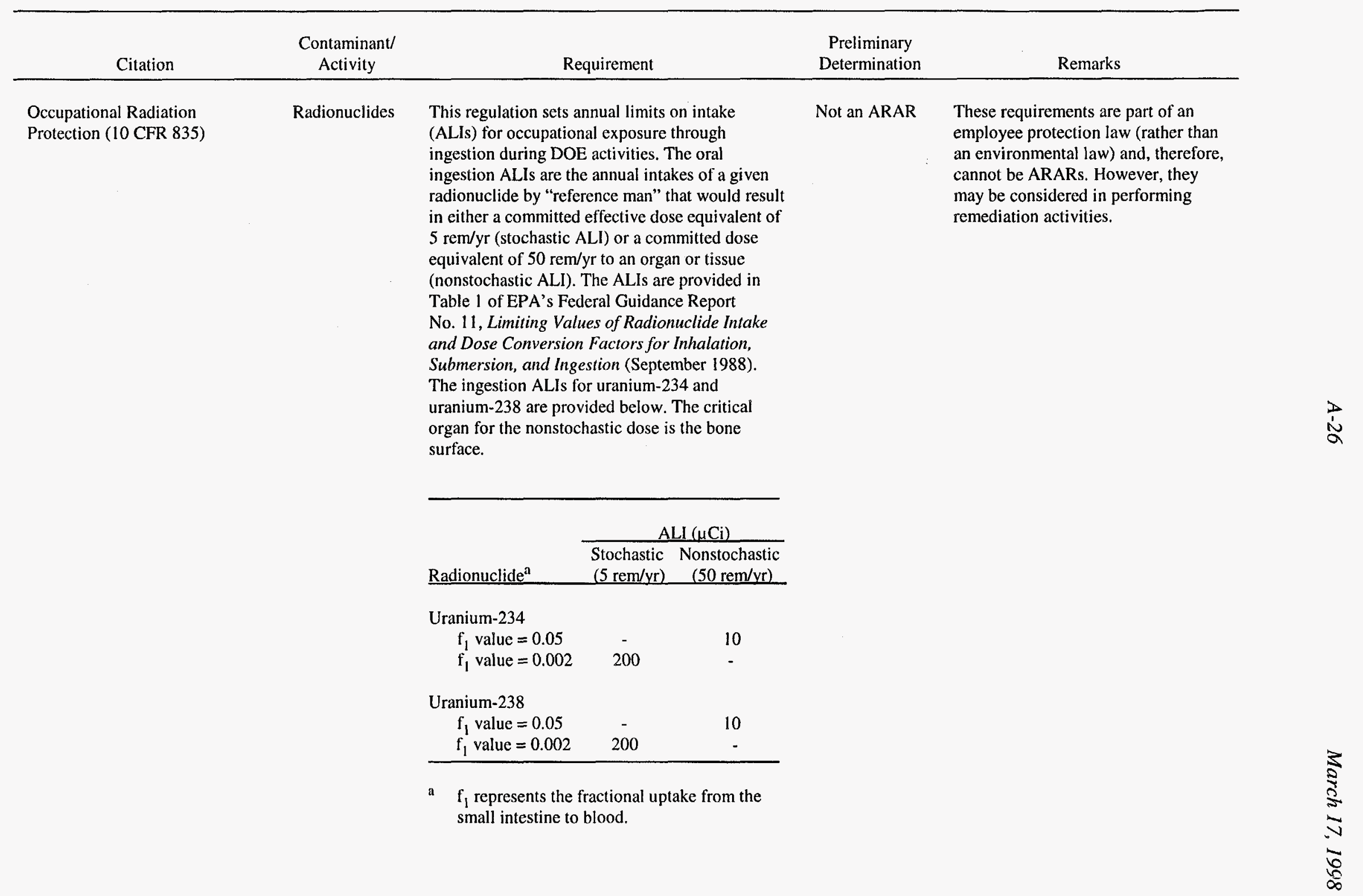


TABLE A.1 (Cont.)

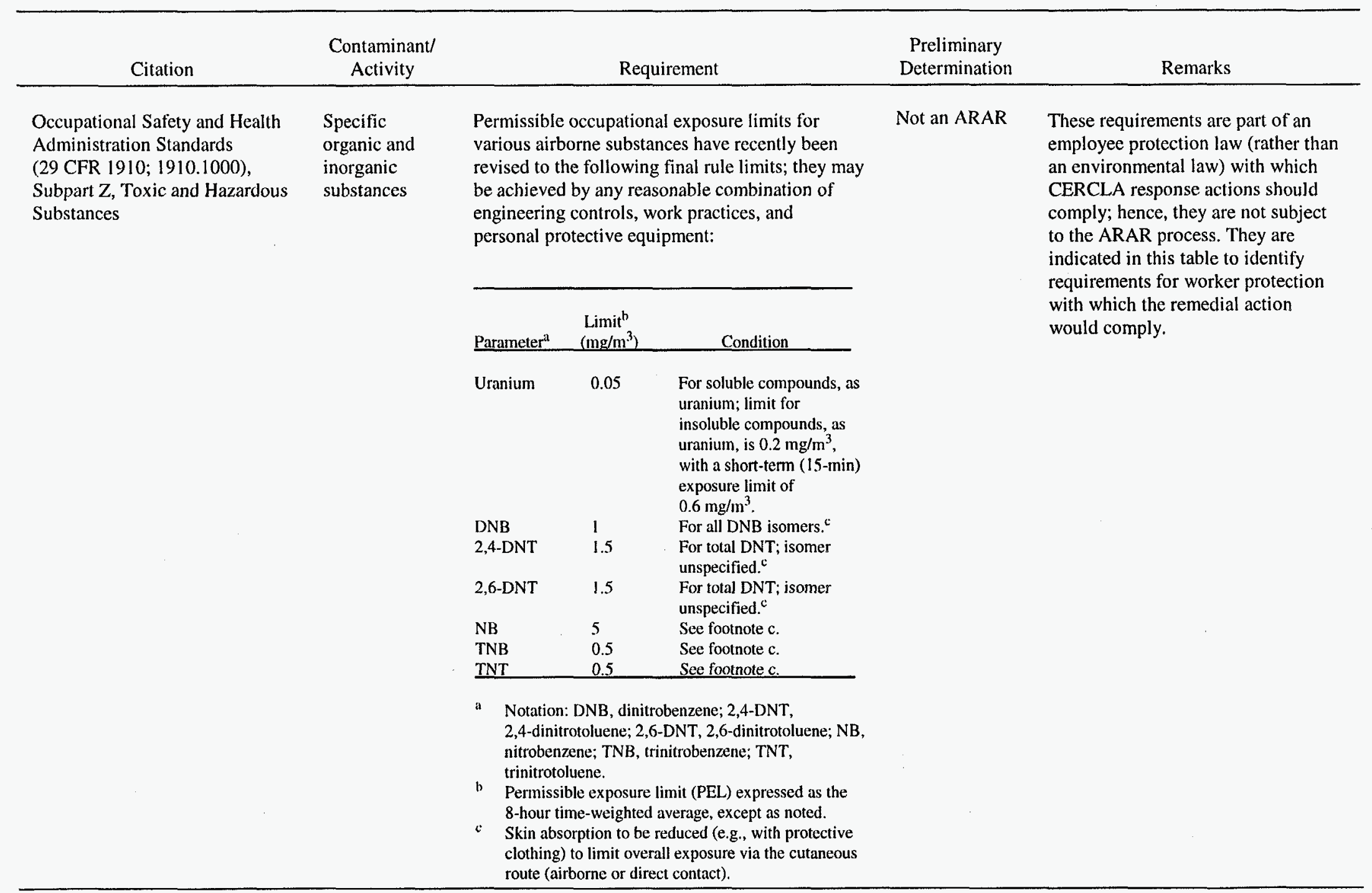


APPENDIX B:

REQUIRED OPERATIONAL PERIOD AND ESTIMATED EXTRACTION FLOW RATES FOR THE INTERCEPTOR TRENCH 


\section{APPENDIX B \\ REQUIRED OPERATIONAL PERIOD AND ESTIMATED EXTRACTION FLOW RATES FOR THE INTERCEPTOR TRENCH}

\section{B.1 INTRODUCTION}

In this analysis, an interceptor trench is defined as a trench used for the purpose of groundwater extraction at a rate equal to the natural groundwater flow rate in the alluvial aquifer. The interceptor trench would be located downgradient of the uranium plume exceeding the metric of $30 \mathrm{pCi} / \mathrm{L}$ and normal to the direction of groundwater flow, and located north of the slough. The interceptor trench would be operated from the time of the completion of trench construction to the time at which the activity of the contaminant of interest (i.e., uranium) would attenuate to $30 \mathrm{pCi} / \mathrm{L}$.

This analysis considers an interceptor trench located at a distance $L$ along a natural flow line from the centroid of the trench (Figure B.1). The analysis consists of determining the required operational period of the trench on the basis of the history of the effluent concentration of the contaminant of interest at the trench. (The following analysis also applies for determining the period of in-situ treatment required for the permeable barrier concept in Alternative 5.) It is conservatively assumed that lateral hydrodynamic dispersion is absent, so that the analysis can be carried out onedimensionally along the flow direction, and that the velocity upstream of the trench is constant in time and space.

With the following initial conditions,

$$
\begin{gathered}
c=c_{0} \text { for }-\frac{W_{P}}{2} \leq x \leq \frac{W_{P}}{2}, \\
\text { elsewhere, } \quad c=0,
\end{gathered}
$$

and the one-dimensional transport equation (Bear 1972),

$$
\left(\theta+\rho_{b} K_{d}\right) \frac{\partial c}{\partial t}+\theta v \frac{\partial c}{\partial x}=\frac{\partial}{\partial x} \theta D_{L} \frac{\partial c}{\partial x}-\lambda\left(\theta+\rho_{b} K_{d}\right) c
$$




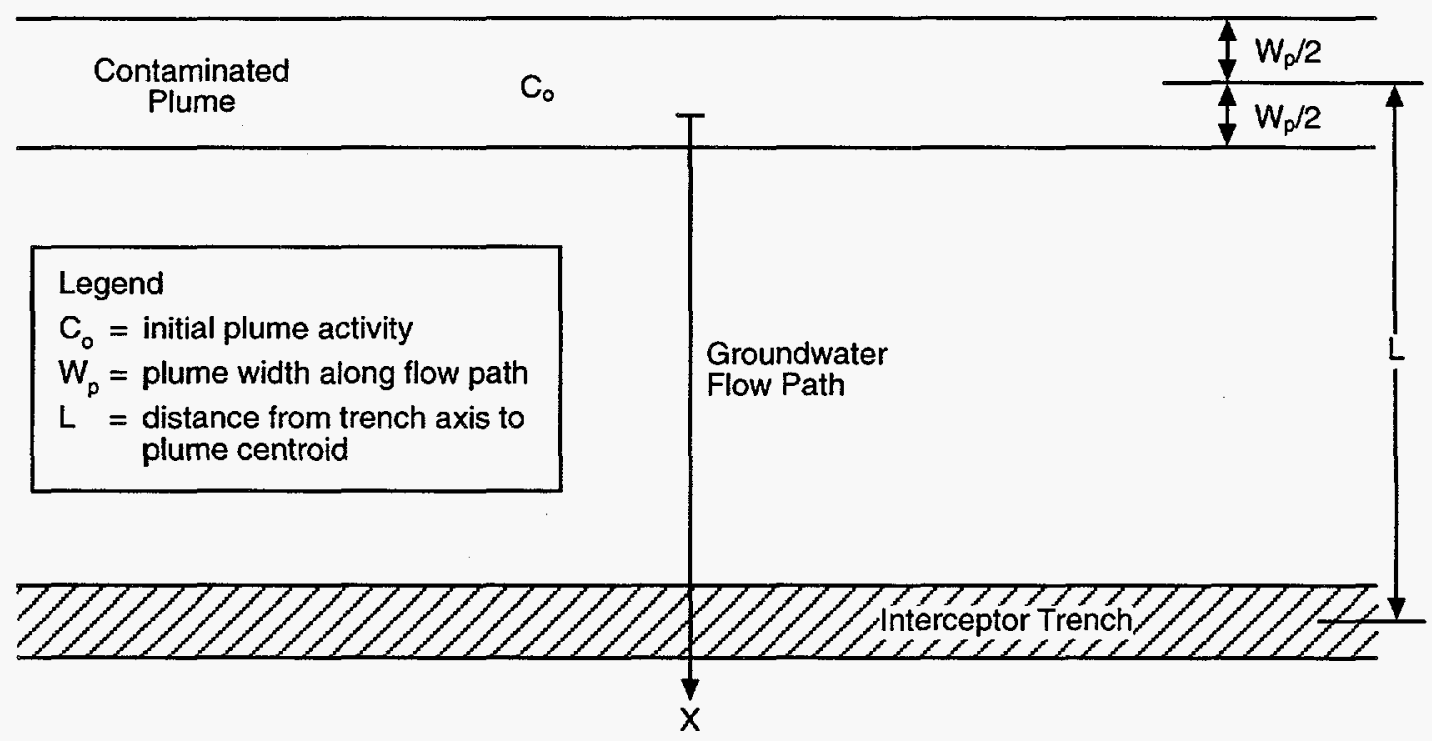

MPA6701

FIGURE B.1 Idealized Interceptor Trench Located Downgradient from an Idealized Contaminant Plume

the concentration at the interceptor trench at time $t$ is given by Carslaw and Jaeger (1978) as

$$
c(L, t)=0.5 c_{0} \exp (-\lambda t)\left[\operatorname{erfc}\left[\frac{L-\frac{v}{R_{d}} t-0.5 W_{p}}{2 \sqrt{\frac{D_{L}}{R_{d}} t}}\right]-\operatorname{erfc}\left[\frac{L-\frac{v}{R_{d}} t+0.5 W_{p}}{2 \sqrt{\frac{D_{L}}{R_{d}} t}}\right],\right.
$$

where

$$
\begin{aligned}
& c=\text { contaminant activity }(\mathrm{pCi} / \mathrm{L}), \\
& c_{0}=\text { initial activity of the plume }(\mathrm{pCi} / \mathrm{L}), \\
& W_{P}=\text { plume width along the considered flowline }(\mathrm{ft}), \\
& x=\text { distance along the considered flowline from the centroid of the plume }(\mathrm{ft}), \\
& L=\text { distance along the considered flowline from the centroid of the plume to the }
\end{aligned}
$$




$$
\begin{aligned}
& R_{d}=\left[1+\frac{\rho_{b}}{\theta} K_{d}\right]=\text { retardation factor (dimensionless) } \\
& \lambda=\text { decay constant }(1 / \mathrm{d}) \text {, } \\
& \rho_{b}=\text { bulk density of soil matrix }(\mathrm{g} / \mathrm{mL}) \text {, } \\
& K_{d}=\text { partition coefficient }(\mathrm{mL} / \mathrm{g}) \text {, } \\
& b=\text { thickness of the alluvial aquifer ( } \mathrm{ft} \text { ), } \\
& t=\text { time interval of interest, } \\
& v=\text { groundwater velocity }=-\frac{K}{\theta} \frac{\partial H}{\partial x}(\mathrm{ft} / \mathrm{d}), \\
& K=\text { hydraulic conductivity }(\mathrm{ft} / \mathrm{d}) \text {, } \\
& D_{L}=\left(\alpha_{L} V\right)+\left(D_{d} T\right)=\text { dispersion coefficient }\left(\mathrm{ft}^{2} / \mathrm{d}\right) \text {, } \\
& \alpha_{L}=\text { longitudinal dispersivity }=(3.28)^{2} \times 0.83 \times\left[\log _{10}\left(\frac{W_{p}}{3.28}\right)\right]^{2.414} \\
& \text { (Xu and Eckstein 1995), } \\
& T=\text { tortuosity of the alluvial aquifer, } \\
& D_{d}=\text { molecular diffusion coefficient }\left(\mathrm{ft}^{2} / \mathrm{d}\right) \text {, } \\
& \theta=\text { effective porosity (dimensionless), and } \\
& H=\text { hydraulic head in the perched zone }(\mathrm{ft}) \text {. }
\end{aligned}
$$

\section{B.2 DETERMINATION OF THE REQUIRED OPERATIONAL PERIOD OF THE INTERCEPTOR TRENCH AND PERMEABLE BARRIER CONCEPTS}

The procedure is to define a contaminated area in which the concentration is approximately uniform. This analysis utilizes the uranium isopleths provided in DOE (1997), which are based on an average uranium concentration of $3,000 \mathrm{pCi} / \mathrm{L}$. 
The operational period was determined using the following parameters:

$\lambda=4.25 \times 10^{-13} \mathrm{~d}^{-1}$ (based on a half-life of $4.468 \times 10^{9}$ year for uranium),

$\rho_{b}=1.2 \mathrm{~g} / \mathrm{mL}$ (average value in density range of 50 to $100 \mathrm{lb} / \mathrm{ft}^{3}$ ),

$K_{d}=5 \mathrm{~L} / \mathrm{kg}$

$\theta=0.27$ (average value in porosity range of 0.21 to 0.32 [Freeze and Cherry 1979]; page G-6 of DOE [1997] indicates an effective porosity range of 0.25 to 0.28 ),

$T=0.29$ (based on Freeze and Cherry [1979]),

$D_{d}=1.86 \times 10^{-3} \mathrm{ft}^{2} / \mathrm{d}$,

$K=1.1 \mathrm{ft} / \mathrm{d}$,

$\frac{\partial H}{\partial X}=0.05 \mathrm{ft} / \mathrm{ft}$, and

$R_{d}=1+\frac{1.2 \times 5}{0.27}=23.2$

On the basis of the above, the following values were estimated:

$$
\begin{gathered}
V=-\frac{K}{\theta} \frac{\partial H}{\partial X}=\frac{1.1 \times 0.05}{0.27}=0.21 \mathrm{ft} / d \\
\left.\alpha_{L}=(3.28)^{2} \times 0.83 \times\left[\log _{10}\left(\frac{W_{p}}{3.28}\right)\right]\right]^{2.414} \\
=\left(3.28^{2} \times 0.83 \times\left[\log _{10}\left(\frac{260}{3.28}\right)\right]^{2.414}=40 \mathrm{ft}\right. \\
D_{\mathrm{L}}=\left(a_{L} \times V\right)+\left(D_{d} \times T\right)=(40 \times 0.21)+\left(1.86 \times 10^{-3} \times 0.29\right)=8.5 \mathrm{ft}^{2} / \mathrm{d}
\end{gathered}
$$


Examination of Figure 9-12A of DOE (1997) provided the following:

$$
\begin{aligned}
& c_{0}=3,000 \mathrm{pCi} / \mathrm{L}, \\
& W_{p}=180 \text { to } 260 \mathrm{ft}, \text { and } \\
& L=120 \text { to } 330 \mathrm{ft} .
\end{aligned}
$$

Using Equation B. 4 and the range of the above parameters, the uranium activity at time $t$ at the interceptor trench can be estimated as shown below:

$c(120 \mathrm{ft}, t)=0.5 \times 3,000 \times \exp \left(-4.25 \times 10^{-13} t\right)\left[\operatorname{erfc}\left[\frac{120-\frac{0.21 t}{23.2}-0.5 \times 180}{2 \sqrt{\frac{8.5}{23.2} t}}\right]\right]$

$$
-\left[\operatorname{erfc}\left[\frac{120-\frac{0.21 t}{23.2}-0.5 \times 180}{2 \sqrt{\frac{8.5}{23.2} t}}\right]\right], \text { and }
$$

$c(330 \mathrm{ft}, t)=0.5 \times 3,000 \times \exp \left(-4.25 \times 10^{-13} t\right)\left[\operatorname{erfc}\left[\frac{330-\frac{0.21 t}{23.2}-0.5 \times 260}{2 \sqrt{\frac{8.5}{23.2} t}}\right]\right]$

$$
-\left[\operatorname{erfc}\left[\frac{330-\frac{0.21 t}{23.2}-0.5 \times 260}{2 \sqrt{\frac{8.5}{23.2} t}}\right]\right]
$$


The time at which the activity would decrease to the metric of $30 \mathrm{pCi} / \mathrm{L}$ was determined by trial and error using a Microsoft Excel ${ }^{\mathrm{TM}}$ spreadsheet (see Figure B.2). Using the above values, the operational duration of the interceptor trench was estimated to range between 240 and 350 years. These operational periods are considerably longer than the 30-year design life of most groundwater treatment facilities.

The time of contaminant transport is sensitive to variation in the value of $K_{d}$. This analysis applies a lower bound value of $5 \mathrm{~mL} / \mathrm{g}$, on the basis of experimental data measured for this FS. A high degree of uncertainty currently exists in the actual values of $K_{d}$ for the alluvial aquifer: However, increasing $K_{d}$ values for uranium will produce more total mass in the alluvial aquifer to be depleted, because the dissolved uranium activity is fixed in this analysis at $3,000 \mathrm{pCi} / \mathrm{L}$ and the adsorbed mass increases with a higher $K_{d}$. Thus, the operational time for higher values of $K_{d}$ would be longer than for the case of $K_{d}=5 \mathrm{~mL} / \mathrm{g}$.

\section{B.3 ESTIMATED EXTRACTION FLOW RATE FOR THE INTERCEPTOR TRENCH CONCEPT}

The extraction flow rate from the interceptor trench concept in Alternative 3 was estimated on the basis of the groundwater velocity, estimated length of the interceptor trench, and aquifer thickness:

$$
Q_{I T}=V \times L_{I T} \times b \times(\text { day } / 1,440 \mathrm{~min}) \times\left(7.48052 \mathrm{gal} / \mathrm{ft}^{3}\right),
$$

where

$$
\begin{aligned}
Q_{I T} & =\text { extraction flow rate from the interceptor trench }(\mathrm{gpm}), \\
V & =\text { groundwater velocity (ft/d; defined in Section B.2), } \\
L_{I T} & =\text { length of interceptor trench (ft), and } \\
b & =\text { thickness of the alluvial aquifer }(\mathrm{ft}) .
\end{aligned}
$$

The extraction flow rate was determined using the following parameters:

$V=0.21 \mathrm{ft} / \mathrm{d}$ (estimated in Section B.2), 


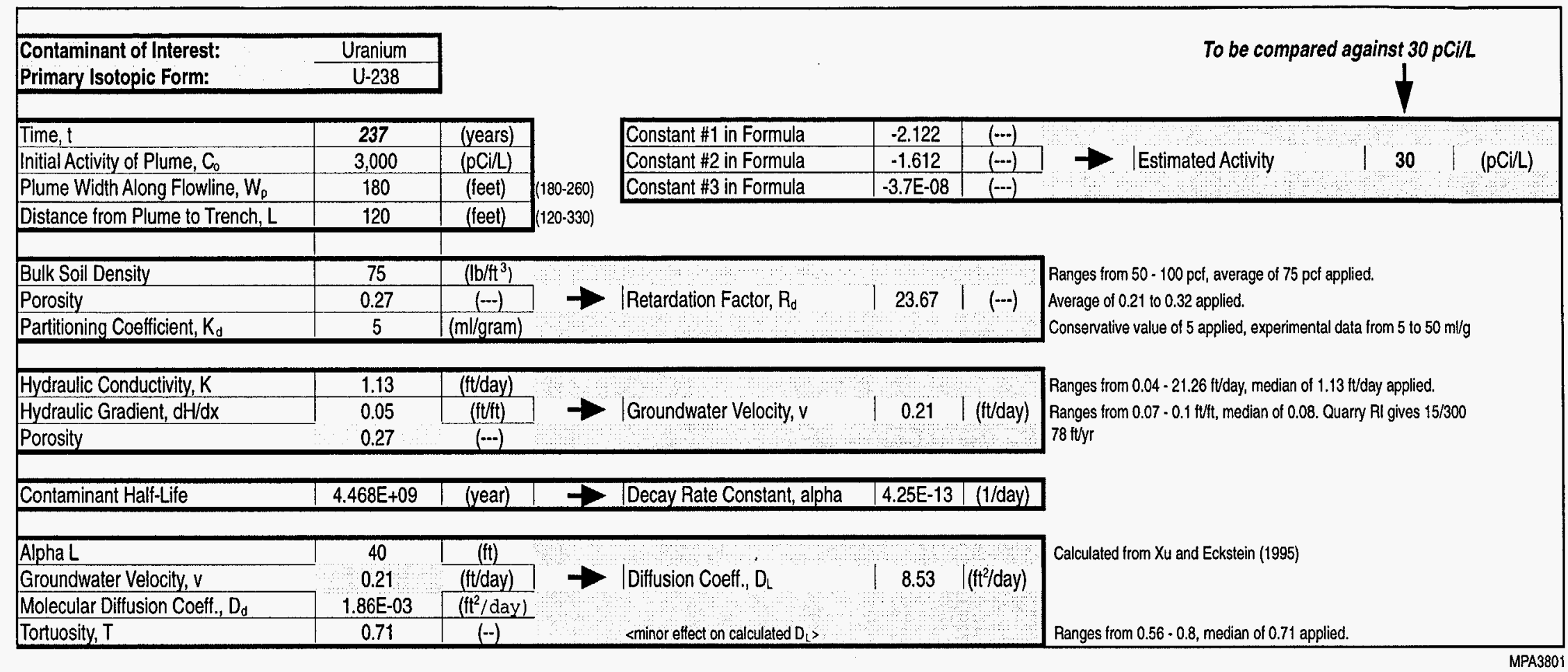

FIGURE B.2 Estimation of the Operational Duration of the Interceptor Trench and Permeable Barrier Concepts 


$$
\begin{aligned}
L_{I T} & =2,000 \mathrm{ft} \text { (based upon examination of the uranium isopleths in DOE [1997]), and } \\
b & =25 \mathrm{ft}
\end{aligned}
$$

which results in a maximum extraction flow rate of approximately $50 \mathrm{gpm}$ (i.e., $Q_{I T}=50 \mathrm{gpm}$ ).

In general, the actual flow rate from an interceptor trench will be less than the maximun due to backflow, bypassing, etc. Assuming a capture efficiency of $67 \%$, the extraction flow rate would be on the order of $30 \mathrm{gpm}(50 \mathrm{gpm} \times 67 \%)$.

For conservatism (in terms of the required operational duration), an interceptor trench flow rate of approximately $50 \mathrm{gpm}$ was applied in this analysis for Alternative 3 .

A similar procedure was performed for Alternative 6, from which an interceptor trench flow rate between 10 and $20 \mathrm{gpm}$ was estimated.

\section{B.4 REFERENCES FOR APPENDIX B}

Bear, J., 1972, Dynamics of Fluids in Porous Media, American Elsevier Publishing Company, Inc., New York, N.Y.

Carslaw, H.S., and J.C. Jaeger, 1978, Conduction of Heat in Solids, 2nd ed., Oxford University Press, Oxford, England.

Freeze, R.A., and J.A. Cherry, 1979, Groundwater, Prentice-Hall, Englewood Cliffs, N.J.

U.S. Department of Energy, 1997, Remedial Investigation for the Groundwater Operable Units at the Chemical Plant Area and the Ordnance Works Area, Weldon Spring, Missouri, DOE/OR/21548-571, prepared by MK-Ferguson Company and Jacobs Engineering Group, Inc., Weldon Spring, Mo., and Argonne National Laboratory, Argonne, Ill., for U.S. Department of Energy, Oak Ridge Operations, Weldon Spring Site Remedial Action Project, Weldon Spring, Mo., and the U.S. Department of the Army, Kansas City District, Feb.

Xu, M., and Y. Eckstein, 1995, "Use of Weighted Least-Squares Method in Evaluation of the Relationship Between Dispersivity and Scale," Journal of Ground Water 3(6):905-908. 


\section{APPENDIX C:}

BED THICKNESS AND OPERATIONAL DURATION OF THE IN-SITU PERMEABLE BARRIER FOR ALTERNATIVE 5 


\section{APPENDIX C:}

\section{BED THICKNESS AND OPERATIONAL DURATION OF THE IN-SITU PERMEABLE BARRIER FOR ALTERNATIVE 5}

A permeable barrier is a structure installed underground to treat contaminated groundwater. In this feasibility study (FS), the proposed permeable barrier would be located downgradient of the uranium contaminated zone exceeding the metric of $30 \mathrm{pCi} / \mathrm{L}$ and normal to the direction of groundwater flow, and located north of the Femme Osage Slough. The bed thickness is dependent on a number of factors, including the contaminant concentration, contaminant half-life through the treatment media, and groundwater velocity. The operational duration of the permeable barrier would be the time period following completion of permeable barrier construction to the time at which the treatment media must be replaced or "regenerated," that is, returned to its original condition by some treatment.

This analysis considers removal of a contaminant (uranium) from an aqueous solution by passage through an adsorbent bed (permeable barrier). The solid permeable barrier is held fixed in location, and the groundwater percolates through it (Figure C.1). In this analysis, a solution containing a single contaminant $A$ at mole fraction $x_{A 1}$ in a solvent $B$ (water) is passed at a constant volumetric flow rate $Q$ through an adsorbent bed. At the start of operations, the interstices of the adsorbent bed are completely filled with pure liquid $B$, and the solid is free of $A$. In this analysis, it is assumed that the resistance of the solid to the mass transfer is negligible.

\section{C.1 THEORY}

The continuity relationships for component $A$ in the solid and liquid phases as a function of distance $z$ within the permeable barrier (Bird, Stewart, and Lightfoot 1960) are as follows:

$$
\begin{gathered}
(1-\epsilon) \frac{\partial c_{A s}}{\partial t}=\left(k_{x} a\right)\left(x_{A}-x_{A 0}\right), \text { and } \\
\epsilon S c \frac{\partial x_{A}}{\partial t}=-W_{B} \frac{\partial x_{A}}{\partial z}-S\left(k_{x} a\right)\left(x_{A}-x_{A 0}\right),
\end{gathered}
$$




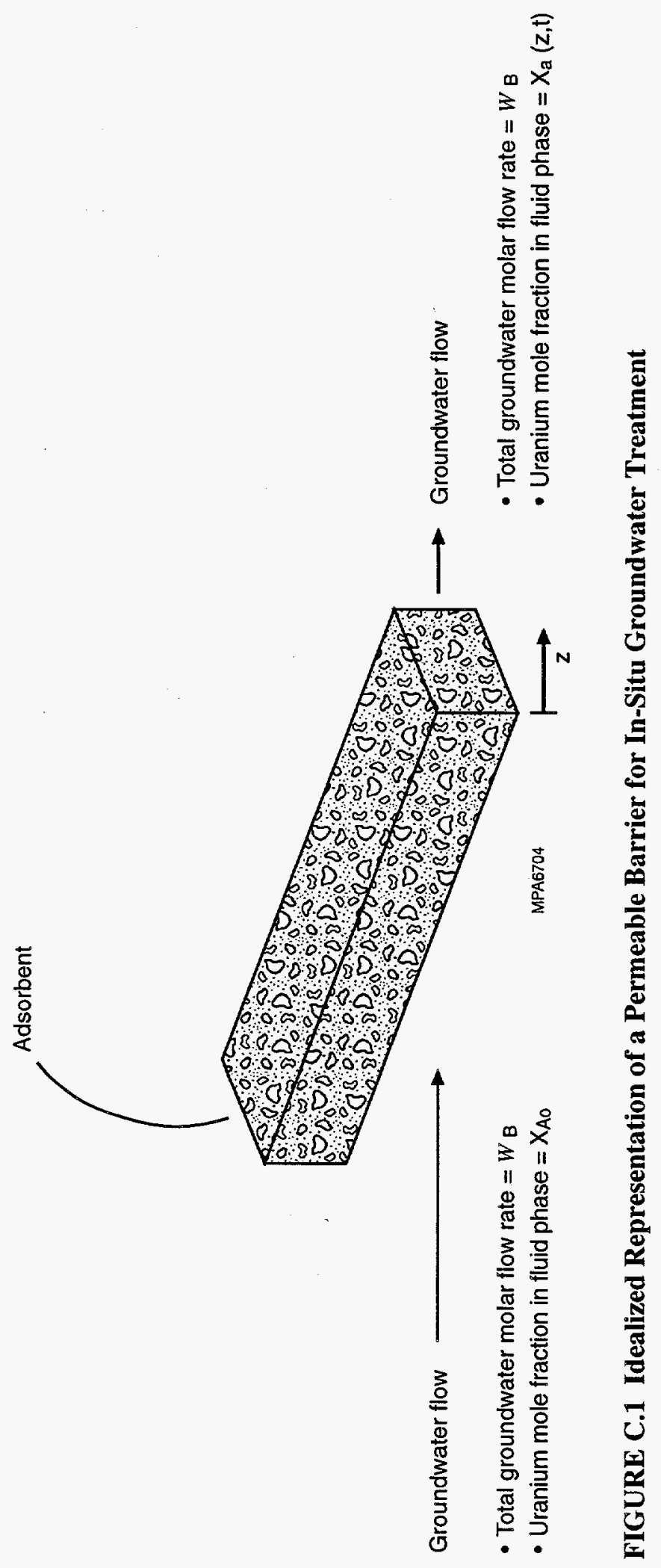


where

$$
\begin{aligned}
\epsilon= & \text { volume fraction of permeable barrier occupied by liquid; } \\
S= & \text { cross-sectional area of permeable barrier; } \\
c= & \text { total molar concentration of the liquid; } \\
c_{A s}= & \text { moles of adsorbed } A \text { (uranium) per unit volume of solid phase; } \\
x_{A}= & \text { bulk mole fraction of } A \text { (uranium) in fluid phase; } \\
x_{A 0}= & \text { interfacial mole fraction of } A \text { in fluid phase, assumed to be in equilibrium with } \\
& c_{A s} ; \\
x_{A 1}= & \text { bulk mole fraction of } A \text { (uranium) entering the permeable barrier; } \\
k_{x}= & \text { fluid-phase mass transfer coefficient; } \\
W_{B}= & \text { time; } \\
m^{\prime}= & \text { constant, defined as the ratio of the interfacial mole fraction of } A \text { in fluid phase } \\
& \left(x_{A 0}\right) \text { to the moles of adsorbed } A \text { per unit volume of solid permeable barrier }\left(c_{A s}\right) ; \\
t^{\prime}= & \text { modified time variable }=t-z\left(\frac{\epsilon S}{W_{b}}\right) ;
\end{aligned}
$$

with the following initial conditions:

$$
\begin{aligned}
& \text { B.C. 1: At } t=0, \quad c_{A s}=0 \quad \text { for all } z>0 \\
& \text { B.C. 2: } \quad \text { At } z=0, \quad x_{A}=x_{A 1} \quad \text { for all } t>0 \text {. }
\end{aligned}
$$

Before solving these equations, it is convenient to rewrite them in terms of the following dimensionless variables:

$$
X=\frac{x_{A}}{x_{A 1}},
$$




$$
\begin{gathered}
Y=\frac{m c_{A s}}{x_{A 1}}, \\
\zeta=\frac{z S\left(k_{x} a\right)}{W_{B}}, \text { and } \\
\tau=\frac{m t^{\circ}\left(k_{x} a\right)}{1-\epsilon} .
\end{gathered}
$$

In terms of these variables, the differential equations and boundary conditions may be written as

$$
\begin{aligned}
& \frac{\partial X}{\partial \zeta}=-(X-Y) \\
& \frac{\partial Y}{\partial \tau}=+(X-Y)
\end{aligned}
$$

B.C. 1: at $\tau=0, \quad Y=0 \quad$ for all $\zeta$

B.C. 2: at $\zeta=0, \quad X=1 \quad$ for all $\tau$

The solution to the above equations is

$$
X=1-\int_{0}^{\zeta} e^{-(\tau+\zeta)} J_{0}(i \sqrt{4 \tau \zeta}) d \zeta
$$

in which $J_{0}(i x)$ is a zero-order Bessel function of the first kind.

The solution presented graphically in Hougen and Watson (1947) is shown in Figure C.2. (In Figure C.2, $y / y_{0}$ corresponds to $X, b \tau$ corresponds to $\tau$, and $a Z$ corresponds to $\zeta$.) 


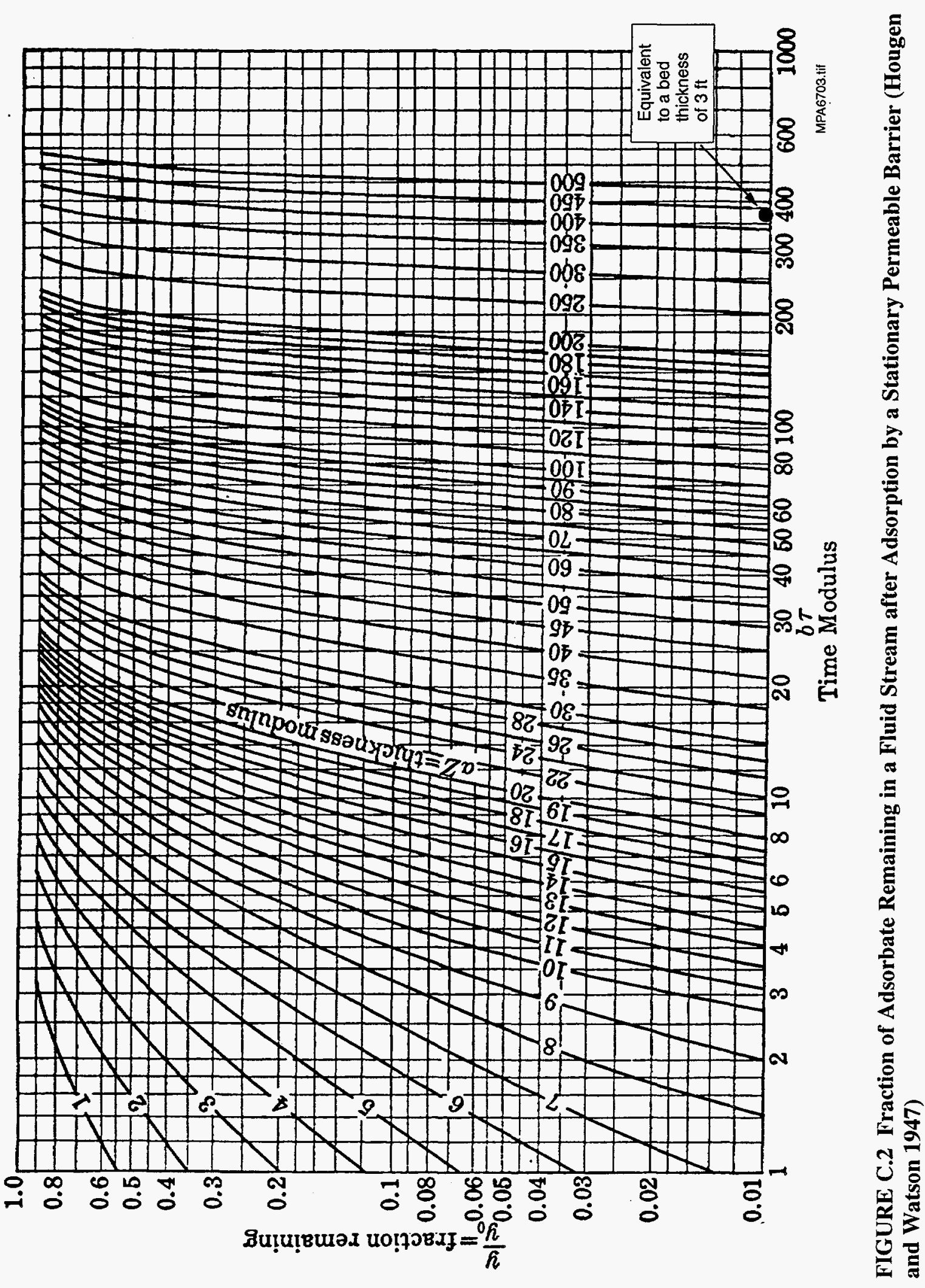




\section{C.2 REQUIRED PERMEABLE BARRIER THICKNESS}

The procedure to estimate the required bed thickness is to determine the thickness modulus $(a Z)$ from Figure C.2, which corresponds to the fraction remaining after adsorption by the permeable barrier $\left(y / y_{0}\right)$ and the time modulus $(b \tau)$. The following parameters were used in this analysis:

$$
\begin{aligned}
& x_{A}=3.3 \times 10^{-9} \mathrm{lb} \text {-mole } \mathrm{U} / \mathrm{lb} \text {-mole total (based on } 30 \mathrm{pCi} / \mathrm{L} \text { ), } \\
& x_{A 0}=1.8 \times 10^{-6} \mathrm{lb} \text {-mole U/lb-mole total (Morrison and Spangler 1992), } \\
& x_{A 1}=3.3 \times 10^{-7} \mathrm{lb} \text {-mole } \mathrm{U} / \mathrm{lb} \text {-mole total (based on } 3,000 \mathrm{pCi} / \mathrm{L} \text { ), } \\
& c_{A s}=6.8 \times 10^{-5} \mathrm{lb}-\text { mole } \mathrm{U} / \mathrm{ft}^{3} \text { clinoptilolite (based upon Morrison and Spangler } \\
& \text { [1992]), } \\
& m=0.027 \mathrm{ft}^{3} \text { clinoptilolite } / \mathrm{lb} \text {-mole total (based upon values of } 1.8 \times 10^{-6} \mathrm{lb} \text {-mole } \\
& \mathrm{U} / \mathrm{lb} \text {-mole total and } 6.8 \times 10^{-5} \mathrm{lb} \text {-mole } \mathrm{U} / \mathrm{ft}^{3} \text { clinoptilolite for } x_{A 0} \text { and } c_{A,} \text {, } \\
& \text { respectively), } \\
& k_{x} a=8.5 \times 10^{-1} \mathrm{lb} \text {-mole } \mathrm{U} / \mathrm{ft}^{3}-\mathrm{h} \text { (Morrison and Spangler 1992), } \\
& a=8.8 \times 10^{6} \mathrm{~m}^{2} / \mathrm{m}^{3} \text { (based upon a surface area of } 4.1 \mathrm{~m}^{2} / \mathrm{g} \text { given in Morrison and } \\
& \text { Spangler [1992] and an average specific gravity of } 2.15 \text { for clinoptilolite), } \\
& \epsilon=0.75 \text {, } \\
& S=60,000 \mathrm{ft}^{2} \text { (based on a permeable barrier length and height of } 2,000 \mathrm{ft} \text { and } 30 \mathrm{ft} \text {, } \\
& \text { respectively), } \\
& W_{B}=311 \mathrm{lb}-\mathrm{mole} \mathrm{H}_{2} \mathrm{O} / \mathrm{h} \text { (based upon a groundwater flow rate of } 15,000 \mathrm{gal} / \mathrm{d} \text { [DOIE } \\
& \text { 1997] and a permeable barrier length of 2,000 ft), and } \\
& c=3.5 \mathrm{lb}-\mathrm{mole} / \mathrm{ft}^{3} \text { (assuming that the contribution of the uranium contamination to } \\
& \text { the total number of moles is negligible); }
\end{aligned}
$$

which corresponds to the following dimensionless variables in Figure C.2:

$$
\begin{aligned}
y / y_{0} & =3.3 \times 10^{-9} / 3.3 \times 10^{-7}=0.01, \\
b \tau & =t-z(0.75 \times 60,000 \times 3.5 / 311) \sim t-510 \times z, \text { and } \\
a Z & =z\left(60,000 \times 8.5 \times 10^{-1} / 311\right) \sim 160 \times z
\end{aligned}
$$


And, since time $(t)$ is related to permeable barrier thickness $(z)$ by the groundwater velocity (approximately $1.5 \times 10^{-3} \mathrm{ft} / \mathrm{h}$, based on a groundwater flow rate of 15,000 gal/d [DOE 1997] over a length of $1,860 \mathrm{ft}$ and a permeable barrier height of $30 \mathrm{ft}$ ),

$$
\begin{aligned}
y / y_{0} & =0.01 \\
b \tau & \sim t-510 \times z=\left(z / 1.5 \times 10^{-3}\right)-(510 \times z) \sim 120 \times z \\
a Z & \sim 160 \times z .
\end{aligned}
$$

Figure C. 2 was used to implement a trial-and-error procedure to determine the value of $z$ that satisfies the above three constraints. A value of $3 \mathrm{ft}$ for the permeable barrier thickness appears to satisfy the specified constraints, as shown by the confluence of the three constraints in Figure C.2.

A permeable barrier thickness of $1 \mathrm{~m}$ ( $3 \mathrm{ft}$ ) was thus applied in the permeable barrier design proposed for Alternative 5.

\section{C.3 OPERATIONAL DURATION FOR THE PERMEABLE BARRIER}

The operational duration of the permeable barrier was estimated on the basis of the total mass of adsorbent (clinoptilolite), the assumed concentration of uranium contamination in the groundwater passing through the permeable barrier, the groundwater flow rate, and the specific capacity of the adsorbent to uranium:

$$
T=M_{c} S C / Q / C_{U}
$$

where

$T=$ operational duration of the permeable barrier before replacement or regeneration is required (years),

$M_{c}=$ total mass of adsorbent (clinoptilolite) in the permeable barrier (grams),

$S C=$ specific capacity of adsorbent for uranium (pCi/gram clinoptilolite),

$Q=$ groundwater flow rate through the permeable barrier $(\mathrm{L} / \mathrm{yr})$, and

$C_{U}=$ uranium concentration in groundwater $(\mathrm{pCi} / \mathrm{L})$. 
The following parameters were used in this analysis:

$$
\begin{aligned}
& M_{c}=1.1 \times 10^{10} \mathrm{~g} \text { (based upon a permeable barrier that is } 2,000 \mathrm{ft} \text { long, } 30 \mathrm{ft} \text { high, and } \\
& 3 \mathrm{ft} \text { thick, and a specific gravity of } 2.15 \mathrm{~g} / \mathrm{cm}^{3} \text { ), } \\
& S C=84 \mathrm{pCi} \mathrm{U/g} \text { clinoptilolite (Morrison and Spangler 1992), } \\
& Q=22 \times 10^{6} \mathrm{~L} / \mathrm{yr} \text { (based on a groundwater flow rate of } 15,000 \mathrm{gal} / \mathrm{d} \text { [DOE 1997] } \\
& \text { over a length of } 1,860 \mathrm{ft} \text { and a permeable barrier length of } 2,000 \mathrm{ft} \text { ), and } \\
& C_{U}=3,000 \mathrm{pCi} / \mathrm{L}
\end{aligned}
$$

which results in the following:

$$
\begin{aligned}
T & =\left(1.1 \times 10^{10} \mathrm{~g}\right)(84 \mathrm{pCi} \mathrm{U} / \mathrm{g} \text { clinoptilolite }) /\left(22 \times 10^{6} \mathrm{~L} / \mathrm{yr}\right) /(3,000 \mathrm{pCi} / \mathrm{L}) \\
& \sim 14 \text { years. }
\end{aligned}
$$

The operational duration of the permeable barrier before replacement or regeneration is required is estimated to be on the order of 14 years.

\section{C.4 REFERENCES FOR APPENDIX C:}

Bird, R.B., et al., 1960, Transport Phenomena, John Wiley \& Sons, Inc., New York, N.Y, pp. 702-705.

Hougen, O.A., and K.M. Watson, 1947, Chemical Process Principles, First Edition, Part III, John Wiley \& Sons, New York, N.Y., p. 1086.

Morrison, S.J., and R.R. Spangler, 1992, "Extraction of Uranium and Molybdenum from Aqueous Solutions: A Survey of Industrial Materials for Use in Chemical Barriers for Uranium Mill Tailings Remediation," Environmental Science and Technology 26(10):1922-1931.

U.S. Department of Energy (DOE), 1997, Remedial Investigation for the Quarry Residuals Operable Unit of the Weldon Spring Site, Weldon Spring, Missouri, DOE/OR/21548-587, Rev. 0, prepared by MK-Ferguson Company and Jacobs Engineering Group, Weldon Spring, Mo., for U.S. Department of Energy Oak Ridge Operations Office, Weldon Spring Site Remedial Action Project, Weldon Spring, Mo. 
APPENDIX D:

ANALYTICAL METHODOLOGIES USED TO ADDRESS ENVIRONMENTAL IMPACTS FOR ALTERNATIVES IN THIS FEASIBILITY STUDY 


\title{
APPENDIX D:
}

\section{ANALYTICAL METHODOLOGIES USED TO ADDRESS ENVIRONMENTAL IMPACTS FOR ALTERNATIVES IN THIS FEASIBILITY STUDY}

\begin{abstract}
This appendix presents the analytical methodologies used to address environmental impacts for the various alternatives. The general methodology for estimating physical hazards and airborne emissions during the construction and operations phases of Alternative 2 is explained. A similar methodology was used to determine the potential impacts of Alternative 6 (Groundwater Removal at Selected Areas, with On-Site Treatment).
\end{abstract}

\section{D.1 PHYSICAL HAZARDS}

The estimated number of worker fatalities and injuries associated with construction and operations were calculated on the basis of statistics available from the U.S. Bureau of Labor Statistics, as reported by the National Safety Council (1995), and on the basis of estimates of total worker hours and full-time equivalents (FTEs) required for construction and operations activities determined from the cost estimates (Appendix E) determined for this feasibility study (FS).

The specific rates used in the calculations were as follows: fatalities during construction, 15 per 100,000 workers; fatalities during operations, 4 per 100,000 workers; injuries during construction, 5.5 per 100 full-time workers; and injuries during operations, 5.3 per 100 full-time workers.

Fatality and injury risks were calculated as the product of the appropriate incidence rate (provided above) and the work hours expended during construction and operations (including both direct and indirect activities), which was then normalized by the number of work hours per day. The fatality and injury incidence during construction of additional monitoring wells equivalent to approximately $15 \%$ of the number of existing wells (i.e., about seven additional wells) was estimated as follows:

$$
\begin{aligned}
\text { (Fatality/Injury Incidence })_{\text {construction }}= & \text { (Construction Work Hours }) /\{(9 \mathrm{mo} / \mathrm{yr}) /(12 \mathrm{mo} / \mathrm{yr}) \\
& \times(52 \mathrm{wk} / \mathrm{yr}) \times[(6.5 \mathrm{~h} / \mathrm{d}) /(8 \mathrm{~h} / \mathrm{d}) \\
& \times(40 \text { work hours per week })]\} \\
& \times(\text { Fatality/Injury Rate })_{\text {construction }}
\end{aligned}
$$

conservatively assuming that construction occurs only 9 months per year (due to winter or flooding) and may require the use of personal protective equipment (resulting in 6.5 hours of actual work per 8 -hour workday). Construction activities are estimated to result in less than one case of occupational 
injury and no occupational fatalities, on the basis of a total of approximately 1,400 construction work hours.

The fatality and injury incidence during annual operations of additional monitoring wells was estimated as follows:

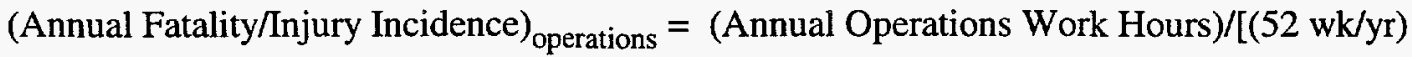

$$
\begin{aligned}
& \times(6.5 \mathrm{~h} / \mathrm{d}) /(8 \mathrm{hr} / \mathrm{d}) \times(40 \text { work hours per week })] \\
& \times(\text { Fatality/Injury Rate })_{\text {operations }} \text {, }
\end{aligned}
$$

assuming that operations may require the use of personal protective equipment (resulting in 6.5 hours of actual work per 8-hour workday). Operations activities associated with the proposed monitoring wells are estimated to result in less than one annual case of occupational injury and no annual occupational fatalities, based upon a total of approximately 1,300 construction work hours.

The fatality and injury incidence during annual operations of the existing monitoring wellis was estimated as follows:

$$
\begin{aligned}
(\text { Annual Fatality/Injury Incidence })_{\text {operations }}= & {[\text { Annual Sampling Labor Costs }(\$ / y r)] / } \\
& (\$ 100,000 \text { per FTE }) \\
& \times(\text { Fatality/Injury Rate })_{\text {operations }},
\end{aligned}
$$

assuming an annual fully loaded labor cost of $\$ 100,000$. (An approach different from that applied for the proposed monitoring wells was used to estimate the fatality and injury incidence for the existing monitoring wells due to the availability of Weldon Spring-specific cost data.) Operations activities associated with the existing monitoring wells were estimated to result in less than one case of annual occupational injury and no annual occupational fatalities, on the basis of an annual labor cost of approximately $\$ 370,000$.

The calculation of fatalities and injuries from industrial accidents was based solely on historical industrywide statistics. The U.S. Department of Energy (DOE) would implement best management practices during any proposed construction and operations activities, and, therefore, fatality and injury incidence rates would be lower than the industrywide rates applied in this analysis.

\section{D.2 AIRBORNE EMISSIONS OF CRITERIA POLLUTANTS}

The emission rate factors used in calculating airborne emissions are presented in Table D.1. The criteria pollutants considered in this analysis include carbon monoxide (CO), hydrocarbons $(\mathrm{HC})$, nitrogen oxides $\left(\mathrm{NO}_{\mathrm{x}}\right)$, sulfur oxides $\left(\mathrm{SO}_{\mathrm{x}}\right)$, and total suspended particulates (TSP). 
TABLE D.1 Criteria Pollutant Emission Rate Factors

\begin{tabular}{lccc}
\hline & \multicolumn{2}{c}{ Construction Equipment ${ }^{\mathrm{a}}(\mathrm{lb} / \mathrm{h})$} & \\
\cline { 2 - 3 } \multicolumn{1}{c}{ Pollutant } & Flatbed Truck & Post Driver & $\begin{array}{c}\text { Worker Vehicle } \\
(\mathrm{g} / \mathrm{km})\end{array}$ \\
\hline Carbon Monoxide & 1.8 & 17 & 7.9 \\
Hydrocarbons & 0.19 & 0.56 & 1.4 \\
Nitrogen Oxides & 4.2 & 0.41 & 1.3 \\
Sulfur Oxides & 0.45 & 0.023 & 0.12 \\
Total Suspended & 0.26 & 0.026 & 0.25 \\
Particulates & & & \\
\hline & & & \\
a Source: EPA (1985). & & & \\
b Source: NRC (1994). &
\end{tabular}

\section{D.2.1 Criteria Pollutant Emissions during Construction}

During the construction phase, the criteria pollutant emissions will consist mainly of construction equipment and worker vehicle emissions. In this analysis, it was assumed that fugitive dust emissions during land clearing would be negligible (because of the limited land area that would be affected by monitoring well construction) and would be suppressed by watering and other containment methods whenever feasible.

Construction equipment emits $\mathrm{CO}, \mathrm{HC}, \mathrm{NO}_{\mathrm{x}}, \mathrm{SO}_{\mathrm{x}}$, and particulates from the combustion of diesel fuel and gasoline. To estimate the quantities of these pollutants, it is necessary to know (1) the type and quantity of equipment that will be used, (2) the number of hours of operations, and (3) the rate at which the pollutants are emitted.

An estimate of the type and quantity of equipment used during monitoring well construction was made by associating the individual activities within the construction cost estimate for Alternative 2 (Appendix E) with the equipment required for that activity. (E.g., a flatbed truck with auger would be required during development of the 20-cm [8-in.] borehole for a 5-cm [2-in.] monitoring well.) This information was provided by the Remedial Action Cost Estimating and Requirements System (RACER) computer model (Delta Research Corporation 1995) used in the calculation of construction costs for this FS. 
The operations time for construction activity $i$ was determined by dividing the direct manpower (in man-hours) by the appropriate crew size:

$(\text { Operations Time }(\mathrm{h}))_{i}=[\text { Manpower (man-hours) }]_{i} /[\text { Crew Size }(\text { workers })]_{i}$

For example, emplacement of a 2-m (5-ft) guard post made of cast iron and filled with concrete requires the services of two laborers (i.e., the crew size in this case equals two).

Emission factors (lb/h) were obtained from EPA (1985) for the construction equipment identified within the construction cost estimate. The emission of pollutant $i$ from construction equipment operations was estimated by the following:

$$
\begin{aligned}
(\text { Emission of Pollutant } i(\mathrm{lb}))_{\text {construction equipment }}= & \left.\sum_{\mathrm{j}} \sum_{\mathrm{k}} \text { [Operation Time }(\mathrm{h})\right]_{\mathrm{j}, \mathrm{k}} \\
& \times[\text { Emission Rate }(\mathrm{lb} / \mathrm{h})]_{\mathrm{i}, \mathrm{k}},
\end{aligned}
$$

by summing over all construction activities $j$ and required construction equipment $k$. Table D.2 shows the predicted emissions from equipment required for monitoring well construction.

Criteria pollutant emissions from construction worker vehicles were estimated assuming an eight-hour workday and that each construction worker travels to and from the construction site in a single vehicle. The number of one-way trips was calculated on the basis of total work hours (both direct and indirect activities) determined within the construction cost estimate for Alternative 2:

$$
(\text { Number of One-Way Trips })=(\text { Total Work Hours }) /(8 \text { Hours per Workday }) \text {. }
$$

\begin{tabular}{|c|c|c|c|c|c|}
\hline \multirow{2}{*}{$\begin{array}{l}\text { Potential } \\
\text { Pollutant }\end{array}$} & \multicolumn{2}{|c|}{$\begin{array}{l}\text { Workday Average Emission } \\
\text { Rate }(\mathrm{lb} / \mathrm{h})\end{array}$} & \multirow{2}{*}{$\begin{array}{l}\text { Flatbed Truck } \\
\text { (h) }\end{array}$} & \multirow[b]{2}{*}{$\begin{array}{l}\text { Post Driver } \\
\text { (h) }\end{array}$} & \multirow[b]{2}{*}{$\begin{array}{l}\text { Emissions } \\
\quad(\mathrm{lb})\end{array}$} \\
\hline & Flatbed Truck & Post Driver & & & \\
\hline $\mathrm{CO}$ & 1.8 & 1.7 & 156 & 17 & 570 \\
\hline $\mathrm{HCs}$ & 0.19 & 0.56 & 156 & 17 & 39 \\
\hline $\mathrm{NO}_{\mathrm{x}}$ & 4.2 & 0.41 & 156 & 17 & 657 \\
\hline $\mathrm{SO}_{\mathrm{x}}$ & 0.45 & 0.023 & 156 & 17 & 71 \\
\hline TSP & 0.26 & 0.026 & 156 & 17 & 40 \\
\hline Aldehydes & 0.11 & 0.020 & 156 & 17 & 18 \\
\hline
\end{tabular}

\section{TABLE D.2 Predicted Emissions from Equipment Required for Monitoring Well} Construction 
For local impacts, it was assumed that the worker vehicles traveled $32 \mathrm{~km}(20 \mathrm{mi})$ to and from work or $64 \mathrm{~km}$ (40 mi) round trip each day. The vehicular emissions of criteria pollutants were calculated by the following:

$$
\begin{aligned}
(\text { Emission of Pollutant } i(\mathrm{lb}))_{\text {worker vehicles }}= & (\text { Number of One-Way Trips }) \\
& \times\{2 \times[\text { One-Way Trip Distance }(\mathrm{mi})]\} \\
& \times(\mathrm{lb} / 453.59 \mathrm{~g}) \times(1.609 \mathrm{~km} / \mathrm{mi}) \\
& \times[\text { Emission Factor }(\mathrm{g} / \mathrm{km})]_{\mathrm{i}},
\end{aligned}
$$

with the predicted values provided in Table D.3.

A significant amount of dust is generated when vehicles travel on unpaved roads. The quantity of dust emissions from a given segment of unpaved road can be determined from the following equation:

$[$ Emission of TSP per Vehicle Mile Traveled $(\mathrm{lb} / \mathrm{VMT})]=5.9(s / 12)(S / 30)\left[(W / 3)^{0.7}\right]\left[(w / 4)^{0.5}\right](365-p) / 365$,

\begin{tabular}{|c|c|c|c|c|}
\hline $\begin{array}{l}\text { Potential } \\
\text { Pollutant } \\
\end{array}$ & $\begin{array}{c}\text { No. of Auto } \\
\text { One-Way Trips }\end{array}$ & $\begin{array}{c}\text { Emission } \\
\text { Factor }(\mathrm{g} / \mathrm{km}) \\
\end{array}$ & $\begin{array}{l}\text { One-Way Trip } \\
\text { Distance (mi) }\end{array}$ & Emission (lb) \\
\hline $\mathrm{CO}$ & 173 & 7.93 & 20 & 194 \\
\hline $\mathrm{HCs}$ & 173 & 1.35 & 20 & 33 \\
\hline $\mathrm{NO}_{\mathrm{x}}$ & 173 & 1.32 & 20 & 32 \\
\hline $\mathrm{SO}_{\mathrm{x}}$ & 173 & 0.12 & 20 & 3 \\
\hline TSP & 173 & 0.25 & 20 & 6 \\
\hline
\end{tabular}
where

$$
\begin{aligned}
s= & \text { silt content of road surface material (assumed to be } 7 \%) \\
S= & \text { mean vehicle speed (mph), } \\
W= & \text { mean vehicle weight (ton), } \\
w= & \text { mean number of wheels, and } \\
p= & \text { number of days with at least } 0.01 \text { in. of precipitation per year } \\
& \text { (approximately } 110 \text { days for Weldon Spring). }
\end{aligned}
$$

TABLE D.3 Predicted Emissions from Construction Worker Vehicles 
It was conservatively assumed in this analysis that all vehicles traveled over unpaved roads without any control measures. On the basis of the vehicles identified in the construction phase for this alternative, the total amount of TSP generated would be on the order of $2,631 \mathrm{~km}(5,800 \mathrm{lb})$.

In general, the total amount of criteria pollutant emissions is estimated to be relatively low (see Table D.4) because of the limited actions associated with monitoring well construction. Vehicle traffic on unpaved surfaces, earthmoving, excavating, and bulldozing would be the major sources of TSP. TSP generation during actual construction activities would be suppressed by watering, revegetation of bare areas, covering open trucks carrying dusty material, removing dirt and debris from the road surface, and using containment methods whenever feasible.

\section{D.2.2 Criteria Pollutant Emissions during Operations}

Airborne emissions of a given criteria pollutant " $\mathrm{i}$ " resulting from operations activities were calculated on the basis of the product of the number of auto one-way trips to the quarry site (for monitoring purposes), with a one-way trip distance (assumed to be $8 \mathrm{~km}$ [5 mi]) and the appropriate vehicular criteria pollutant emission rate factor from Table D.1:

$$
\begin{aligned}
\text { (Number of One-Way Trips })= & \text { (Total Number of Monitoring Wells) } \\
& \times[\text { Sampling Frequency (times per year) }] / \\
& \text { (Number of Wells Sampled per Trip) } .
\end{aligned}
$$

The total number of monitoring wells was assumed to be 52 (45 existing plus 7 proposed), with a quarterly sampling frequency (i.e., sampled every three months) and only one well sampled during each trip (examination of recent groundwater sampling data for the Quarry Residuals Operable Unit [QROU] indicates a median of three wells sampled per trip).

TABLE D.4 Total Predicted Construction Emissions for Alternative 2 (No Active Remediation)

\begin{tabular}{lcccc}
\hline $\begin{array}{c}\text { Potential } \\
\text { Pollutant }\end{array}$ & $\begin{array}{c}\text { Construction } \\
\text { Equipment }\end{array}$ & $\begin{array}{c}\text { Worker } \\
\text { Vehicles }\end{array}$ & $\begin{array}{c}\text { Unpaved } \\
\text { Roads }\end{array}$ & Total (lbs) \\
\hline $\mathrm{CO}$ & 570 & 194 & 0 & 760 \\
$\mathrm{HCs}$ & 39 & 33 & 0 & 70 \\
$\mathrm{NO}_{\mathrm{x}}$ & 657 & 32 & 0 & 690 \\
$\mathrm{SO}_{\mathrm{x}}$ & 71 & 3 & 0 & 70 \\
$\mathrm{TSP}$ & 40 & 6 & 5,800 & 5,850 \\
\hline
\end{tabular}




$$
\begin{aligned}
\text { [Annual Emission }(\mathrm{lb} / \mathrm{yr})]_{\mathrm{i}}= & (\text { Number of One-Way Trips }) \\
& \times\{2 \times[\text { One-Way Trip Distance }(\mathrm{mi})]\} \\
& \times(\mathrm{lb} / 453.59 \mathrm{~g}) \times(1.609 \mathrm{~km} / \mathrm{mi}) \\
& \times[\text { Emission Factor }(\mathrm{g} / \mathrm{km})]_{\mathrm{i}}
\end{aligned}
$$

It was also assumed that each operations worker travels to and from the QROU in a single vehicle (no car pooling) and that the worker vehicles traveled $8 \mathrm{~km}(5 \mathrm{mi})$ to and from the QROU or a 16-km (10-mi) round trip. Emission factors ( $\mathrm{g} / \mathrm{km}$ traveled) were obtained from NRC (1994). (The difference in emission factors between those obtained from NRC (1994) and those obtained by running the EPA-approved vehicle emission models MOBILE 5a [EPA 1994a] and PART5 [EPA 1994b] was determined to be less than 10\%.) The predicted annual emissions from vehicles used by monitoring workers is shown in Table D.5.

\section{D.3 REFERENCES FOR APPENDIX D}

Delta Research Corporation, 1995, Remedial Action Cost Estimating and Requirements System (RACER) User Manual, Niceville, Fla.

National Safety Council, 1995, Accidents Facts, 1995 Edition, Itasca, Ill.

U.S. Environmental Protection Agency, 1985, Compilation of Air Pollutant Emission Factors, Volume 1: Stationary Point and Area Sources, AP-42, 4th ed., Washington, D.C.

U.S. Environmental Protection Agency, 1994a, Users Guide to MOBILE 5a, EPA-AA-AQAB-94-01, Office of Air and Radiation, Washington, D.C., May.

U.S. Environmental Protection Agency, 1994b, Draft User's Guide to PART5: A Program for Calculating Particle Emissions from Motor Vehicles, National Motor Vehicle and Fuels Emission Laboratory, Office of Mobile Sources, Ann Arbor, Mich., July.

U.S. Nuclear Regulatory Commission, 1994, Final Environmental Impact Statement for the Construction and Operation of Claiborne Enrichment Center, Homer, Louisiana, NUREG-1484, Vol. 1, Office of Nuclear Material Safety and Safeguards, Washington, D.C., Aug. 


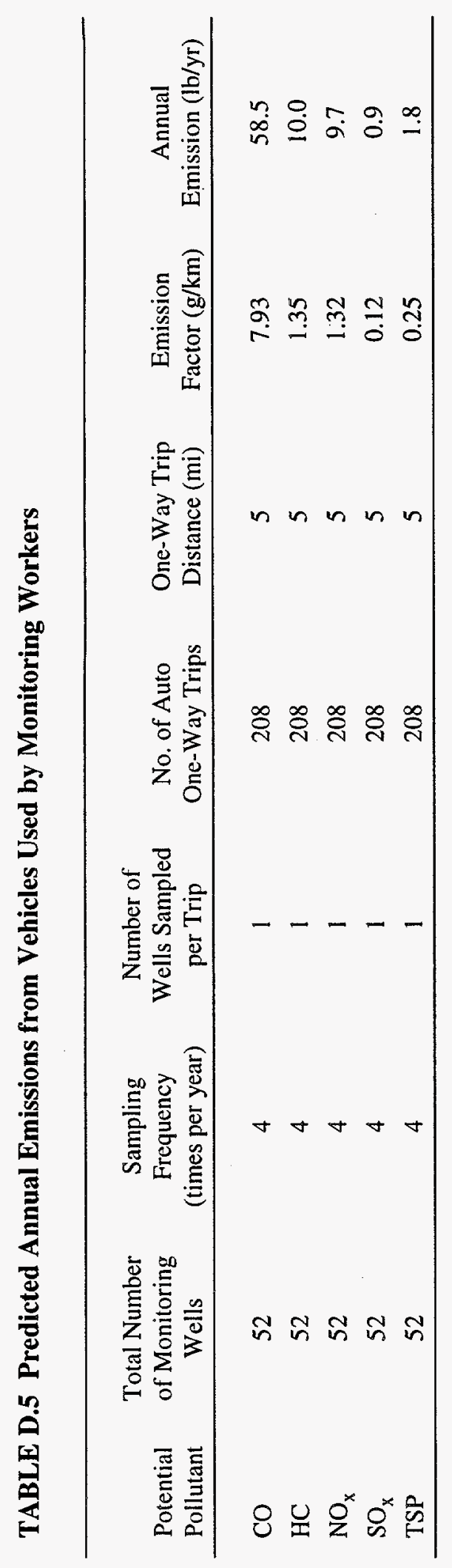




\section{APPENDIX E:}

METHODOLOGY AND ASSUMPTIONS USED TO DETERMINE THE COSTS OF THE VARIOUS ALTERNATIVES IN THIS FEASIBILITY STUDY 


\title{
APPENDIX E:
}

\section{METHODOLOGY AND ASSUMPTIONS USED TO DETERMINE THE COSTS OF THE VARIOUS ALTERNATIVES IN THIS FEASIBILITY STUDY}

\begin{abstract}
This appendix discusses the methodology and assumptions used to determine the costs of the various alternatives considered in this feasibility study (FS). Unless noted otherwise, the direct costs for both construction and operations phases were developed using the Version 3.20 of the Remedial Action Cost Estimating and Requirements System (RACER) computer model (Delta Research Corporation 1995).
\end{abstract}

\section{E.1 REMEDIAL ACTION COST ESTIMATING AND REQUIREMENTS SYSTEM (RACER) SYSTEM}

The RACER system was developed by the U.S. Air Force to estimate the total cost (both direct and indirect) of remedial actions. RACER is a PC-based environmental cost estimating system that can be used to provide programming, budgeting, and cost engineering support during various phases of remediation: Preliminary Assessment/Site Investigation [PA/SI] Studies, Petroleum Underground Storage Tank Site Assessment, Remedial Investigation [RI]/FS, and Remedial Facility Investigation [RFI/Corrective Measures Study [CMS], Remedial Design, Remedial Action (including Operations and Maintenance $[O \& M]$ ), and Site Work and Utilities.

The RACER estimating process involves a series of basic steps, including calculation of site (direct) costs and project costs. A project may consist of a single site or it may contain several sites. For each site included in the project, the user can select and run the technologies and/or processes (cost models) that will be used to remediate the site. The costs calculated for these models are direct costs only (i.e., the cost does not include contractor overhead and profit, cost for contingencies, project management, or escalation). Once direct costs have been calculated for all cost models included in each site of the project, the user completes the estimate by calculating the project costs. Project costs include costs for contractor overhead and profit, contingencies, project management, and escalation. RACER was used in this analysis to determine only the direct costs (costs that can be directly attributed to a particular item of work or activity). Weldon Spring-specific indirect cost relationships (Hood 1997) were applied in this analysis rather than the generic indirect cost relationships provided by the RACER model.

RACER uses a parametric modeling technique similar to the U.S. Air Force's Construction Cost Management Analysis System (CCMAS). The basic concept of RACER is that predefined engineering relationships link primary parameters to detailed quantities. These quantities are then priced using established cost databases. RACER cost models are based on generic engineering 
solutions for environmental projects, technologies, and processes. The engineering solutions were derived from research, government laboratories, construction management agencies, vendors, contractors, engineering analyses, and historic project information. Design parameters within the cost models were tailored by the cost estimator to reflect specific project conditions and requirements. The design was then tailored by RACER into specific quantities of work, which were priced using current price data. The assembly cost database within RACER was developed from the U.S. Army Corps of Engineers' Unit Price Book (COE 1989) and supplemented by vendor and contractor quotes. A cost differential was included in this analysis to account for the differences in material and labor costs in the Weldon Spring area compared with the generic Unit Price Book costs.

Professional labor includes activities that provide interpretation of the performance of the remedial action during both the construction/startup and O\&M phases of the environmental restoration process. Typical professional labor activities associated with remedial action construction include oversight of construction activities, permit acquisition, and "as built" drawings. Professional labor activities associated with O\&M include evaluation of sampling and analysis data, comparison of results with project goals, coordination of field activities, and documentation and reporting of all efforts. Estimates of professional labor were derived by RACER using a parametric approach based on similar levels of activities for related projects.

\section{E.2 ESTIMATION OF INDIRECT COSTS}

Indirect costs are defined as those costs that cannot be identified specifically with a particular activity, cannot be charged to a specific element of work, or do not become a permanent part of any facility constructed. Indirect costs - small tools and supplies, fringes, insurance, and contingency - were estimated on the basis of various percentages of other costs specific to the Weldon Spring site (Hood 1997). The various indirect cost relationships applied in this analysis are provided in Table E.1 and were implemented using a Microsoft Excel ${ }^{\text {TM }}$ spreadsheet for each alternative.

Contingency costs are added to a project to cover costs that may result from incomplete design, unforeseen and unpredictable conditions, or uncertainties within the defined scope. In general, the contingency cost is derived from the difference between the $5 \%$ and $50 \%$ chance of overrun of the base estimate. A contingency percentage of $25 \%$ was applied in this analysis, based upon Hood (1997), which is within the range recommended by the U.S. Department of Energy (DOE) Office of Environmental Management for projects in the preliminary stage of the remediation process (DOE 1990). 
TABLE E.1 Weldon Spring-Specific Indirect Cost Relationships Applied in This FS

\begin{tabular}{|c|c|c|}
\hline Indirect Cost Component & Relationship & Applied Under \\
\hline Small tools and supplies & $5 \%$ of total direct labor cost & Cost of Supplies \\
\hline Level D personnel protection & $0.179 \times$ direct manpower & Cost of Supplies \\
\hline State sales and use tax & $\begin{array}{l}7.23 \% \text { of cost of permanent } \\
\text { materials and supplies }\end{array}$ & $\begin{array}{l}\text { Cost of Permanent Materials } \\
\text { and Supplies }\end{array}$ \\
\hline Indirect labor & $25 \%$ of total direct labor cost & Cost of OH/Fee/Con ${ }^{a}$ \\
\hline Plant operations & $8.8 \%$ of total direct labor cost & Cost of $\mathrm{OH} / \mathrm{Fee} / \mathrm{Con}$ \\
\hline Fringes & $29 \%$ of indirect labor & Cost of OH/Fee/Con \\
\hline Margin & $\begin{array}{l}10 \% \text { of sum of direct cost and all } \\
\text { indirect costs above }\end{array}$ & Cost of OH/Fee/Con \\
\hline Bond & $\begin{array}{l}2 \% \text { of sum of direct cost and all } \\
\text { indirect costs above }\end{array}$ & Cost of OH/Fee/Con \\
\hline Insurance & $\begin{array}{l}10 \% \text { of sum of direct cost and all } \\
\text { indirect costs above }\end{array}$ & Cost of $\mathrm{OH} / \mathrm{Fee} / \mathrm{Con}$ \\
\hline Contingency & $\begin{array}{l}25 \% \text { of sum of direct cost and all } \\
\text { indirect costs above }\end{array}$ & Cost of $\mathrm{OH} / \mathrm{Fee} / \mathrm{Con}$ \\
\hline
\end{tabular}

\section{E.3 PRESENT-WORTH ANALYSIS}

Present worth is defined as the investment-evaluation procedure that involves discounting the sums of capital investment, $O \& M$, and repairs at a specified interest rate (representing cost of capital or minimum acceptable rate of return). The following analysis complies with the requirements described by the Office of Management and Budget (OMB) Circular No. A-94, the National Bureau of Standards Handbook 135 prepared for DOE, and the U.S. Environmental Protection Agency (EPA) Office of Solid Waste and Emergency Response (OSWER) Directive 9355.3-01 (EPA 1988) for adjusting for converting cash flows at different times to correspond at a common time during the preparation of a cost estimate. 
The costs calculated in this analysis are given in 1995 constant dollars. The constant dollar cash flows occurring at different times are converted by the present-worth analysis into a timeequivalent lump sum amount evaluated at the beginning of the base year. This is performed by using, an interest rate or "real discount rate" that reflects the opportunity cost apart from any change in the: purchasing power of the dollar. A Uniform Series Present Worth Factor (P/A) is calculated using the real discount rate $i$ :

$$
(P / A)=\left[(1+i)^{\mathrm{n}}-1\right] / i /(1+i)^{n},
$$

where $n$ is the project duration.

A discount rate of $7 \%$ (before taxes and after inflation) was applied in this analysis; (OSWER Directive 9355.3-20, EPA 1993). Long-term operations costs were based on a 30-yea: period per instructions in EPA (1988) and include annual sampling and analytical costs.

\section{E.4 EXAMPLE CONSTRUCTION COST CALCULATION FOR ALTERNATIVE 2:}

The construction of approximately $15 \%$ of the number of existing wells (i.e., seven additional wells) was conservatively assumed in Alternative 2 (Monitoring with No Active: Remediation) to evaluate the protectiveness of this alternative. The following assumptions were made during the development of the construction costs for this alternative:

- Installation in an unconsolidated formation;

- Safety level D conditions during construction (Level D provides minimal protection against respiratory hazards. Coveralls, hard hat, leather or chemical-resistant boots/shoes, and safety glasses or chemical splash goggles are required. Personal dosimeters are included for level D radioactive sites.);

- Material of construction is stainless steel (for long-term effectiveness purposes);

- Well diameter of $5 \mathrm{~cm}$ (2 in.); and

- Dedicated pumps provided for each well for purge and sampling purposes.

Additional characteristics of the proposed wells are provided in Table E.2. 
TABLE E.2 Characteristics of Proposed Additional Monitoring Wells for Alternative 2 (Monitoring with No Active Remediation)

\begin{tabular}{ccc}
\hline Number of Wells & $\begin{array}{c}\text { Depth to } \\
\text { Top of Screen } \\
(\mathrm{ft})\end{array}$ & $\begin{array}{c}\text { Screen Length } \\
(\mathrm{ft})\end{array}$ \\
\hline 3 & 21 & 8 \\
3 & 20 & 15 \\
1 & 25 & 25 \\
\hline
\end{tabular}

This information was used with the RACER model to determine the direct construction costs. The indirect cost relationships provided in Table E.1 were then applied to determine the total construction cost (direct and indirect). The detailed construction cost estimate is given in Table E. 3 .

\section{E.5 EXAMPLE OF A PRESENT-WORTH COST CALCULATION FOR ALTERNATIVE 2}

Costs for Alternative 2 would be associated with continuing the existing environmental monitoring program, constructing and operating the proposed additional monitoring wells, and conducting a performance review every five years. The methodology outlined in Section E. 3 was implemented within a Microsoft Excel ${ }^{\mathrm{TM}}$ spreadsheet, as shown in Table E.4. The spreadsheet methodology was developed to allow a variable discount rate and operations duration, to allow for consideration of different "what-if" scenarios. 
TABLE E.3 Construction Cost Estimate for Alternative 2 (Monitoring with No Active Remediation)

\begin{tabular}{|c|c|c|c|c|c|c|c|c|c|c|c|}
\hline $\begin{array}{l}\text { WBS } \\
\text { Element }\end{array}$ & Description & Quantity & Unit & $\begin{array}{l}\text { Manpower } \\
\text { (man hours) }\end{array}$ & $\begin{array}{l}\text { Labor } \\
(\$)\end{array}$ & $\begin{array}{l}\text { Equip } \\
\text { (\$) }\end{array}$ & $\begin{array}{l}\text { Perm Matl } \\
\text { (\$) }\end{array}$ & $\begin{array}{l}\text { Supplies } \\
\text { (\$) }\end{array}$ & $\begin{array}{c}\text { Sub-Contracts } \\
(\$)\end{array}$ & $\begin{array}{l}\mathrm{OH} / \mathrm{Fee} / \mathrm{Con} \\
(\$)\end{array}$ & $\begin{array}{l}\text { Total Cost } \\
(\$)\end{array}$ \\
\hline \multirow[t]{18}{*}{33.02 .04 .01} & $\begin{array}{l}\text { Three Groundwater Monitoring } \\
\text { Wells in Alluvium, North of Slough }\end{array}$ & & & & & & & & & & \\
\hline & $\begin{array}{l}\text { Furnish 55-Gal Drum for Drilling } \\
\text { Cuttings \& Devel Water }\end{array}$ & 4 & each & 0 & 0.00 & 0.00 & 169.69 & 0.00 & 0.00 & 0.00 & 169.69 \\
\hline & Well Development Equipment Rental & 1 & week & 3 & 38.63 & 0.37 & 376.76 & 0.00 & 0.00 & 0.00 & 415.76 \\
\hline & $\begin{array}{l}\text { Split Spoon Sample, 2" × 24", } \\
\text { During Drilling }\end{array}$ & 18 & each & 0 & 0.00 & 0.00 & 445.50 & 0.00 & 0.00 & 0.00 & 445.50 \\
\hline & OVA Rental, Per Day & 2 & day & 0 & 0.00 & 0.00 & 198.00 & 0.00 & 0.00 & 0.00 & 198.00 \\
\hline & $\begin{array}{l}\text { Decontaminate Rig, Augers, Screen } \\
\text { (Rental Equipment) }\end{array}$ & 2 & day & 0 & 0.00 & 0.00 & 269.28 & 0.00 & 0.00 & 0.00 & 269.28 \\
\hline & Surface Pad, Concrete, $2^{\prime} \times 2^{*} \times 4^{\prime \prime}$ & 3 & each & 1 & 3.00 & 0.12 & 7.92 & 0.00 & 0.00 & 0.00 & 11.04 \\
\hline & $\begin{array}{l}5^{\prime} \text { Guard Posts, Cast Iron, Concrete } \\
\text { Fill }\end{array}$ & 12 & each & 25 & 340.02 & 4.48 & 292.29 & 0.00 & 0.00 & 0.00 & 636.79 \\
\hline & H Stem, 8" OD Borehole for 2" Well & 90 & LNFT & 66 & 907.11 & $1,164.08$ & 0.00 & 0.00 & 0.00 & 0.00 & $2,071.19$ \\
\hline & 2" Well, Bentonite Seal & 3 & each & 2 & 18.71 & 24.01 & 43.04 & 0.00 & 0.00 & 0.00 & 85.76 \\
\hline & 2" Well, Portland Cement Grout & 51 & LNFT & 0 & 0.00 & 0.00 & 45.44 & 0.00 & 0.00 & 0.00 & 45.44 \\
\hline & 2" Screen, Filter Pack & 33 & LNFT & 4 & 51.83 & 66.51 & 191.59 & 0.00 & 0.00 & 0.00 & 309.93 \\
\hline & 2" Stainless Steel, Well Casing & 71 & LNFT & 12 & 1.54 .81 & 198.67 & $1,102.01$ & 0.00 & 0.00 & 0.00 & $1,455.49$ \\
\hline & 2" Stainless Stecl, Well Screen & 24 & LNFT & 4 & 44.35 & $56.9 !$ & 964.27 & 0.00 & 0.00 & 0.00 & $1,065.53$ \\
\hline & 2" Stainless Steel, Well Plug & 3 & each & 2 & 16.63 & 21.34 & 75.33 & 0.00 & 0.00 & 0.00 & 113.30 \\
\hline & GW Pump, 1/3 HP, Controls & 3 & each & 51 & 692.93 & 7.56 & $13,768.92$ & 0.00 & 0.00 & 0.00 & $14,469.41$ \\
\hline & Mob/Demob Drilling Rig \& Crew & 1 & LS & 41 & 554.28 & 711.36 & 0.00 & 0.00 & 0.00 & 0.00 & $1,265,64$ \\
\hline & Move Rig/Equipment Around Site & 2 & each & 3 & 34.64 & 44.46 & 0.00 & 0.00 & 0.00 & 0.00 & 79.10 \\
\hline
\end{tabular}


TABLE E.3 (Cont.)

\begin{tabular}{|c|c|c|c|c|c|c|c|c|c|c|c|}
\hline $\begin{array}{l}\text { WBS } \\
\text { Element }\end{array}$ & Description & Quantity & Unit & $\begin{array}{l}\text { Manpower } \\
\text { (man hours) }\end{array}$ & $\begin{array}{c}\text { Labor } \\
(\$)\end{array}$ & $\begin{array}{c}\text { Equip } \\
(\$)\end{array}$ & $\begin{array}{l}\text { Perm Matl } \\
\text { (\$) }\end{array}$ & $\begin{array}{c}\text { Supplies } \\
(\$)\end{array}$ & $\begin{array}{l}\text { Sub-Contracts } \\
(\$)\end{array}$ & $\begin{array}{l}\mathrm{OH} / \mathrm{Fee} / \mathrm{Con} \\
(\$)\end{array}$ & $\begin{array}{l}\text { Total Cost } \\
\text { (\$) }\end{array}$ \\
\hline \multirow[t]{18}{*}{33.02 .04 .02} & $\begin{array}{l}\text { Three Groundwater Monitoring } \\
\text { Wells in Decorah, North of Slough }\end{array}$ & & & & & & & & & & \\
\hline & $\begin{array}{l}\text { Furnish 55-Gal Drum for Drilling } \\
\text { Cuttings \& Devel Water }\end{array}$ & 6 & each & 0 & 0.00 & 0.00 & 254.53 & 0.00 & 0.00 & 0.00 & 254.53 \\
\hline & Well Development Equipment Rental & 1 & week & 3 & 38.63 & 0.37 & 376.76 & 0.00 & 0.00 & 0.00 & 415.76 \\
\hline & $\begin{array}{l}\text { Split Spoon Sample, } 2 " \times 24 " \text {, } \\
\text { During Drilling }\end{array}$ & 21 & each & 0 & 0.00 & 0.00 & 519.75 & 0.00 & 0.00 & 0.00 & 519.75 \\
\hline & OVA Rental, Per Day & 2 & day & 0 & 0.00 & 0.00 & 198.00 & 0.00 & 0.00 & 0.00 & 198.00 \\
\hline & $\begin{array}{l}\text { Decontaminate Rig, Augers, Screen } \\
\text { (Rental Equipment) }\end{array}$ & 2 & day & 0 & 0.00 & 0.00 & 269.28 & 0.00 & 0.00 & 0.00 & 269.28 \\
\hline & Surface Pad, Concrete, $2^{\prime} \times 2^{\prime} \times 4^{\prime \prime}$ & 3 & each & 1 & 3.00 & 0.12 & 7.92 & 0.00 & 0.00 & 0.00 & 11.04 \\
\hline & $\begin{array}{l}\text { 5' Guard Posts, Cast Iron, Concrete } \\
\text { Fill }\end{array}$ & 12 & each & 25 & 340.02 & 4.48 & 292.29 & 0.00 & 0.00 & 0.00 & 636.79 \\
\hline & H Stem, 8" OD Borehole for 2" Well & 108 & LNFT & 79 & $1,088,53$ & $1,396.90$ & 0.00 & 0.00 & 0.00 & 0.00 & $2,485.43$ \\
\hline & 2" Well, Bentonite Seal & 3 & each & 2 & 18.71 & 24.01 & 43.04 & 0.00 & 0.00 & 0.00 & 85.76 \\
\hline & 2" Well, Portland Cement Grout & 48 & LNFT & 0 & 0.00 & 0.00 & 42.77 & 0.00 & 0.00 & 0.00 & 42.77 \\
\hline & 2" Screen, Filter Pack & 54 & LNFT & 7 & 84.82 & 108.84 & 313.51 & 0.00 & 0.00 & 0.00 & 507.17 \\
\hline & 2" Stainless Steel, Well Casing & 68 & LNFT & 11 & 148.27 & 190.27 & $1,055.44$ & 0.00 & 0.00 & 0.00 & $1,393.98$ \\
\hline & 2" Stainless Steel, Well Screen & 45 & LNFT & 7 & 8.7 .15 & 106.71 & $1,808.01$ & 0.00 & 0.00 & 0.00 & $1,997.87$ \\
\hline & $2^{n}$ Stainless Steel, Well Plug & 3 & each & 2 & 16.63 & 21.34 & 75.33 & 0.00 & 0.00 & 0.00 & 113.30 \\
\hline & GW Pump, $3 / 4$ HP, Controls & 3 & each & 51 & 692.95 & 7.54 & $13,204.62$ & 0.00 & 0.00 & 0.00 & $13,905.11$ \\
\hline & Mob/Demob Drilling Rig \& Crew & 1 & LS & 41 & 554.28 & 711.36 & 0.00 & 0.00 & 0.00 & 0.00 & $1,265.64$ \\
\hline & Move Rig/Equipment Around Site & 2 & each & 3 & 34.64 & 44.46 & 0.00 & 0.00 & 0.00 & 0.00 & 79.10 \\
\hline \multirow[t]{6}{*}{33.02 .04 .03} & $\begin{array}{l}\text { One Groundwater Monitoring Well } \\
\text { in Alluvium, South of Slough }\end{array}$ & & & & & & & & & & \\
\hline & $\begin{array}{l}\text { Furnish 55-Gal Drum for Drilling } \\
\text { Cuttings \& Devel Water }\end{array}$ & 2 & each & 0 & 0.00 & 0.00 & 84.84 & 0.00 & 0.00 & 0.00 & 84.84 \\
\hline & Well Development Equipment Rental & 1 & week & 3 & 38.63 & 0.37 & 376.76 & 0.00 & 0.00 & 0.00 & 415.76 \\
\hline & $\begin{array}{l}\text { Split Spoon Sample, 2" } \times 24 " \text {, } \\
\text { During Drilling }\end{array}$ & 10 & each & 0 & 0.00 & 0.00 & 247.50 & 0.00 & 0.00 & 0.00 & 247.50 \\
\hline & OVA Rental, Per Day & 1 & day & 0 & 0.00 & 0.00 & 99.00 & 0.00 & 0.00 & 0.00 & 99.00 \\
\hline & $\begin{array}{l}\text { Decontaminate Rig, Augers, Screen } \\
\text { (Rental Equipment) }\end{array}$ & 1 & day & 0 & 0.00 & 0.00 & 134.64 & 0.00 & 0.00 & 0.00 & 134.64 \\
\hline
\end{tabular}


TABLE E.3 (Cont.)

\begin{tabular}{|c|c|c|c|c|c|c|c|c|c|c|c|}
\hline $\begin{array}{l}\text { WBS } \\
\text { Elenent }\end{array}$ & Description & Quantity & Unir & $\begin{array}{l}\text { Manpower } \\
\text { (man hours) }\end{array}$ & $\begin{array}{l}\text { Labor } \\
(\$)\end{array}$ & $\begin{array}{l}\text { Equip } \\
\text { (\$) }\end{array}$ & $\begin{array}{l}\text { Perm Matl } \\
\quad(\$)\end{array}$ & $\underset{(\$)}{\text { Supplies }}$ & $\begin{array}{l}\text { Sub-Contracts } \\
\text { (\$) }\end{array}$ & $\begin{array}{l}\mathrm{OH} / \mathrm{Fee} / \mathrm{Con} \\
(\$)\end{array}$ & $\begin{array}{c}\text { Total Cost } \\
\text { (\$) }\end{array}$ \\
\hline \multirow[t]{12}{*}{33.02 .04 .03} & $\begin{array}{l}\text { One Groundwater Monitoring Well } \\
\text { in Alluvium, South of Slough } \\
\text { (Cont.) }\end{array}$ & & & & & & & & & & \\
\hline & Surface Pad, Concrete, $2^{\prime} \times 2^{\prime} \times 4^{\prime \prime}$ & 1 & each & 1 & 1.00 & 0.04 & 2.64 & 0.00 & 0.00 & 0.00 & 3.68 \\
\hline & $\begin{array}{l}5{ }^{\prime} \text { Guard Posts, Cast Iron, Concrete } \\
\text { Fill }\end{array}$ & 4 & each & 9 & 113.34 & 1.49 & 97.43 & 0.00 & 0.00 & 0.00 & 212.26 \\
\hline & H Stem, 8 " OD Borehole for 2" Well & 51 & LNFT & 38 & 514,03 & 659.65 & 0.00 & 0.00 & 0.00 & 0.00 & $1,173.68$ \\
\hline & 2" Well, Bentonite Seal & 1 & each & 1 & 6.24 & 8.00 & 14.35 & 0.00 & 0.00 & 0.00 & 28.59 \\
\hline & 2" Well, Portland Cement Grout & 21 & LNFT & 0 & 0.00 & 0.00 & 18.71 & 0.00 & 0.00 & 0.00 & 18.71 \\
\hline & 2" Screen, Filter Pack & 28 & LNFT & 4 & 43.98 & 56.44 & 162.56 & 0.00 & 0.00 & 0.00 & 262.98 \\
\hline & 2" Stainless Steel, Well Casing & 28 & LNFT & 5 & 61.05 & 78.35 & 434.59 & 0.00 & 0.00 & 0.00 & 573.99 \\
\hline & 2" Stainless Steel, Well Screen & 25 & LNFT & 4 & 46.20 & 59.28 & $1,004.45$ & 0.00 & 0.00 & 0.00 & $1,109.93$ \\
\hline & 2" Stainless Steel, Well Plug & 1 & each & 1 & 5.54 & 7.11 & 25.11 & 0.00 & 0.00 & 0.00 & 37.76 \\
\hline & GW Pump, 1/3 HP, Controls & 1 & each & 17 & 230.98 & 2.52 & $4,589.64$ & 0.00 & 0.00 & 0.00 & $4,823,14$ \\
\hline & Mob/Demob Drilling Rig \& Crew & 1 & LS & 41 & 554.28 & 711.36 & 0.00 & 0.00 & 0.00 & 0.00 & $1,265.64$ \\
\hline \multirow[t]{2}{*}{33.23 .11 .01} & Drilling \& Installation & & & & & & & & & & \\
\hline & $\begin{array}{l}\text { Monitoring Well Slug Testing } \\
\text { Equipment Rental }\end{array}$ & 7 & week & 0 & 0.00 & 0.00 & $4,989.60$ & 0.00 & 0.00 & 0.00 & $4,989,60$ \\
\hline \multirow[t]{8}{*}{33.80 .01 .01} & Construction Support & & & & & & & & & & \\
\hline & Project Engineer & 18 & hour & 18 & 616.50 & 0.00 & 0.00 & 0.00 & 0.00 & 0.00 & 616.50 \\
\hline & Staff Engineer & 180 & hour & 180 & $4,685.40$ & 0.00 & 0.00 & 0.00 & 0.00 & 0.00 & $4,685,40$ \\
\hline & Staff Hydrogeologist & 14 & hour & 14 & 364.42 & 0.00 & 0.00 & 0.00 & 0.00 & 0.00 & 364.42 \\
\hline & Field Technician & 174 & hour & 174 & $2,860.56$ & 0.00 & 0.00 & 0.00 & 0.00 & 0.00 & $2,860.56$ \\
\hline & Certified Industrial Hygienist & 9 & hour & 9 & 308.25 & 0.00 & 0.00 & 0.00 & 0.00 & 0.00 & 308.25 \\
\hline & Junior Geologist & 84 & hour & 84 & $1,265.88$ & 0.00 & 0.00 & 0.00 & 0.00 & 0.00 & $1,265.88$ \\
\hline & Other Direct Costs & 1 & LS & 0 & 0.00 & 0.00 & 145.53 & 0.00 & 0.00 & 0.00 & 145.53 \\
\hline
\end{tabular}


TABLE E.3 (Cont.)

\begin{tabular}{|c|c|c|c|c|c|c|c|c|c|c|c|}
\hline $\begin{array}{c}\text { WBS } \\
\text { Element }\end{array}$ & Description & Quantity & Unit & $\begin{array}{c}\text { Manpower } \\
\text { (man hours) }\end{array}$ & $\begin{array}{l}\text { Labor } \\
(\$)\end{array}$ & $\begin{array}{l}\text { Equip } \\
\text { (\$) }\end{array}$ & $\begin{array}{l}\text { Perm Matl } \\
\text { (\$) }\end{array}$ & $\begin{array}{c}\text { Supplies } \\
(\$)\end{array}$ & $\begin{array}{l}\text { Sub-Contracts } \\
\text { (\$) }\end{array}$ & $\begin{array}{c}\mathrm{OH} / \mathrm{Fee} / \mathrm{Con} \\
(\$)\end{array}$ & $\begin{array}{c}\text { Total Cost } \\
(\$)\end{array}$ \\
\hline \multirow[t]{7}{*}{33.80 .01 .04} & "As Buill" Drawings & & & & & & & & & & \\
\hline & Staff Engineer & 3 & hour & 3 & 78.09 & 0.00 & 0.00 & 0.00 & 0.00 & 0.00 & 78.09 \\
\hline & Surveyor & 6 & hour & 6 & 123.30 & 0.00 & 0.00 & 0.00 & 0.00 & 0.00 & 123.30 \\
\hline & Field Technician & 6 & hour & 6 & 98.64 & 0.00 & 0.00 & 0.00 & 0.00 & 0.00 & 98.64 \\
\hline & Draftsman/CADD Operator & 18 & hour & 18 & 295.92 & 0.00 & 0.00 & 0.00 & 0.00 & 0.00 & 295.92 \\
\hline & Word Processing/Clerical & 6 & hour & 6 & 82.20 & 0.00 & 0.00 & 0.00 & 0.00 & 0.00 & 82.20 \\
\hline & Other Direct Costs & 1 & LS & 0 & 0.00 & 0.00 & 8.91 & 0.00 & 0.00 & 0.00 & 8.91 \\
\hline \multirow[t]{8}{*}{33.80 .01 .06} & Monitoring Reports & & & & & & & & & & \\
\hline & Project Engineer & 8 & hour & 8 & 274.00 & 0.00 & 0.00 & 0.00 & 0.00 & 0.00 & 274.00 \\
\hline & Staff Engineer & 18 & hour & 18 & 468.54 & 0.00 & 0.00 & 0.00 & 0.00 & 0.00 & 468.54 \\
\hline & Staff Hydrogeologist & 8 & hour & 8 & 208.24 & 0.00 & 0.00 & 0.00 & 0.00 & 0.00 & 208.24 \\
\hline & Field Technician & 20 & hour & 20 & 328.80 & 0.00 & 0.00 & 0.00 & 0.00 & 0.00 & 328.80 \\
\hline & Draftsman/CADD Operator & 36 & hour & 36 & 591.84 & 0.00 & 0.00 & 0.00 & 0.00 & 0.00 & 591.84 \\
\hline & Word Processing/Clerical & 20 & hour & 20 & 274.00 & 0.00 & 0.00 & 0.00 & 0.00 & 0.00 & 274.00 \\
\hline & Other Direct Costs & 1 & LS & 0 & 0.00 & 0.00 & 30.69 & 0.00 & 0.00 & 0.00 & 30.69 \\
\hline \multirow[t]{6}{*}{33.80 .01 .24} & Sampling and Analysis Plan & & & & & & & & & & \\
\hline & Project Engineer & 3 & hour & 3 & 102.75 & 0.00 & 0.00 & 0.00 & 0.00 & 0.00 & 102.75 \\
\hline & Staff Engineer & 12 & hour & 12 & 312.36 & 0.00 & 0.00 & 0.00 & 0.00 & 0.00 & 312.36 \\
\hline & Word Processing/Clerical & 12 & hour & 12 & 164.40 & 0.00 & 0.00 & 0.00 & 0.00 & 0.00 & 164.40 \\
\hline & Certified Industrial Hygienist & 3 & hour & 3 & 102.75 & 0.00 & 0.00 & 0.00 & 0.00 & 0.00 & 102.75 \\
\hline & Other Direct Costs & 1 & LS & 0 & 0.00 & 0.00 & 8.91 & 0.00 & 0.00 & 0.00 & 8.91 \\
\hline \multirow[t]{4}{*}{33.80 .01 .32} & Health and Safety Plan & & & & & & & & & & \\
\hline & Project Engineer & 5 & hour & 5 & 171.25 & 0.00 & 0.00 & 0.00 & 0.00 & 0.00 & 171.25 \\
\hline & Certified Industrial Hygienist & 50 & hour & 50 & $1,712.50$ & 0.00 & 0.00 & 0.00 & 0.00 & 0.00 & $1,712.50$ \\
\hline & Other Direct Costs & 1 & LS & 0 & 0.00 & 0.00 & 26.73 & 0.00 & 0.00 & 0.00 & 26.73 \\
\hline
\end{tabular}


TABLE E.3 (Cont.)

\begin{tabular}{|c|c|c|c|c|c|c|c|c|c|c|c|}
\hline $\begin{array}{c}\text { WBS } \\
\text { Element }\end{array}$ & Description & Quantity & Unit & $\begin{array}{l}\text { Manpower } \\
\text { (man hours) }\end{array}$ & $\begin{array}{c}\text { Labor } \\
\text { (\$) }\end{array}$ & $\begin{array}{l}\text { Equip } \\
\text { (\$) }\end{array}$ & $\begin{array}{c}\text { Perm Matl } \\
(\$)\end{array}$ & $\begin{array}{c}\text { Supplies } \\
\text { (\$) }\end{array}$ & $\begin{array}{l}\text { Sub-Contracts } \\
(\$)\end{array}$ & $\begin{array}{c}\mathrm{OH} / \mathrm{Fee} / \mathrm{Con} \\
\text { (\$) }\end{array}$ & $\begin{array}{c}\text { Total Cost } \\
\text { (\$) }\end{array}$ \\
\hline \multirow[t]{7}{*}{33.80 .01 .46} & Work Plan Amendments & & & & & & & & & & \\
\hline & Project Engineer & 15 & hour & 15 & 513.75 & 0.00 & 0.00 & 0.00 & 0.00 & 0.00 & 513.75 \\
\hline & Staff Engineer & 34 & hour & 34 & 88.02 & 0.00 & 0.00 & 0.00 & 0.00 & 0.00 & 885.02 \\
\hline & Word Processing/Clerical & 40 & hour & 40 & 548.00 & 0.00 & 0.00 & 0.00 & 0.00 & 0.00 & 548.00 \\
\hline & Certified Industrial Hygienist & 15 & hour & 15 & 513.75 & 0.00 & 0.00 & 0.00 & 0.00 & 0.00 & 513.75 \\
\hline & Other Direct Cosis & 1 & LS & 0 & 0.00 & 0.00 & 34.65 & 0.00 & 0.00 & 0.00 & 34.65 \\
\hline & TOTAL DIRECT COST: & & & 1,387 & $25,526.95$ & $6,500.88$ & $48,948.53$ & 0.00 & 0.00 & 0.00 & $80,976.36$ \\
\hline 40.00 .00 .00 & Small Tools \& Supplies & $5 \%$ & Labor \$ & 0 & 0.00 & 0.00 & 0.00 & $1,276.35$ & 0.00 & 0.00 & $1,276.35$ \\
\hline 50.00 .00 .00 & Level D Personnel Protection & 0.179 & Manpower & 0 & 0.00 & 0.00 & 0.00 & 248.27 & 0.00 & 0.00 & 248.27 \\
\hline 60.00 .00 .00 & Subtotal 1 & & & 1,387 & $25,526.95$ & $6,500.88$ & $48,948.53$ & $1,524,62$ & 0.00 & 0.00 & $82,500.98$ \\
\hline 70.00 .00 .00 & State Sales \& Use Tax & $7.23 \%$ & $\begin{array}{l}\text { Perm Matl, } \\
\text { Supplies }\end{array}$ & 0 & 0.00 & 0.00 & $3,538.98$ & 110.23 & 0.00 & 0.00 & $3,649.21$ \\
\hline 80.00 .00 .00 & Subtotal 2 & & & 1,387 & $25,526,95$ & $6,500,88$ & $52,487.51$ & $1,634.85$ & 0.00 & 0.00 & $86,150.19$ \\
\hline 90.00 .00 .00 & Indirect Labor & $25 \%$ & Direct Labor & 3.36 & 0.00 & 0.00 & 0.00 & 0.00 & 0.00 & $6,381.74$ & $6,381.74$ \\
\hline 100.00 .00 .00 & PInt Op Cost & $8.8 \%$ & Direct Labor & 118 & 0.00 & 0.00 & 0.00 & 0.00 & 0.00 & $2,246,37$ & $2,246.37$ \\
\hline 110.00 .00 .00 & Subtotal Indirects & & & 454 & 0.00 & 0.00 & 0.00 & 0.00 & 0.00 & $8,628.11$ & $8,628.11$ \\
\hline $120,00,00.00$ & Fringes & $29 \%$ & Indirect Labor & 0 & 0.00 & 0.00 & 0.00 & 0.00 & 0.00 & $2,502.15$ & $2,502.15$ \\
\hline 130.00 .00 .00 & Subtotal 3 & & & 1,841 & $25,526.95$ & $6,500.88$ & $52,487.51$ & $1,634,85$ & 0.00 & $11,130.26$ & $97,280.45$ \\
\hline $140,00,00,00$ & Margin & $10 \%$ & Above Cost & 0 & 0.00 & 0.00 & 0.00 & 0.00 & 0.00 & $9,728.05$ & $9,728,05$ \\
\hline 150.00 .00 .00 & Subtotal 4 & & & 1,841 & $25,526.95$ & $6,500.88$ & $52,487.51$ & $1,634.85$ & 0.00 & $20,858.31$ & $107,008.50$ \\
\hline 160.00 .00 .00 & Bond & $2 \%$ & Above Cost & 0 & 0.00 & 0.00 & 0.00 & 0.00 & 0.00 & $2,140.17$ & $2,140.17$ \\
\hline 170.00 .00 .00 & Subtotal 5 & & & 1,841 & $25,526.95$ & $6,500.88$ & $52,487.51$ & $1,634.85$ & 0.00 & $22,998.48$ & $109,148.66$ \\
\hline 180.00 .00 .00 & Insurance & $10 \%$ & Above Cost & 0 & 0.00 & 0.00 & 0.00 & 0.00 & 0.00 & $10,914.87$ & $10,914.87$ \\
\hline 190.00 .00 .00 & Subtotal 6 & & & 1,841 & $25,526.95$ & $6,500.88$ & $52,487.51$ & $1,634.85$ & 0.00 & $33,913.34$ & $120,063,53$ \\
\hline \multirow[t]{3}{*}{200.00 .00 .00} & Contingency & $25 \%$ & Above Cost & 0 & 0.00 & 0.00 & 0.00 & 0.00 & 0.00 & $30,015.88$ & $30,015.88$ \\
\hline & TOTAL INDIRECT COST: & & & 454 & o & 0 & 3,539 & 1,635 & 0 & 63,929 & 69,103 \\
\hline & OVERALL TOTAL: & & & 1,841 & 25,527 & 6,501 & 52,488 & 1,635 & $\mathbf{0}$ & 63,929 & 150,079 \\
\hline
\end{tabular}


TABLE E.4 Present-Worth Cost Calculation for Alternative 2 (Monitoring with No Active Remediation)

\begin{tabular}{|c|c|c|c|c|c|c|c|}
\hline Discount Rate (\%): & $7 \%$ & & & & & & \\
\hline Operations Duration (years): & 30 & & & & & & \\
\hline Item Description & Quantity & Units & $\begin{array}{c}\text { Duration } \\
\text { (year) }\end{array}$ & $\begin{array}{l}\text { Unit Cost } \\
\text { (\$/unit) }\end{array}$ & $\begin{array}{l}\text { Cost in } \\
\text { Current Dollars } \\
(\$)\end{array}$ & $\begin{array}{l}\text { Present-Worth } \\
\text { Cost } \\
\text { (\$) }\end{array}$ & Reference \\
\hline \multicolumn{8}{|l|}{ CAPITAL COSTS: } \\
\hline Direct Cost, Groundwater Monitoring Wells & 7 & wells & & 11,571 & 81,000 & 81,000 & ANL Cost Estimate \\
\hline Indirect Cost, Groundwater Monitoring Wells & & , & & & 69,100 & 69,100 & ANL Cost Estimate \\
\hline Well Restrictions & 0 & LS & & 20,000 & 0 & 0 & FS for OW, 1993 \\
\hline TOTAL CAPITAL COSTS & & & & & 150,000 & 150,000 & \\
\hline \multicolumn{8}{|l|}{ ANNUAL COSTS: } \\
\hline Groundwater Monitoring, Sampling Labor & 29 & wells & 30 & 370,671 & $11,120,000$ & $4,600,000$ & MK-Ferguson \\
\hline $\begin{array}{l}\text { Groundwater Monitoring, Analytical Costs } \\
\text { (based upon } 37 \text { samples per round, annual } \\
\text { sampling; } \$ 210 \text { analysis cost per sample) }\end{array}$ & 29 & wells & 30 & 7,770 & 233,000 & 96,000 & MK-Ferguson \\
\hline Groundwater Monitoring, Proposed Wells & 7 & wells & 30 & 110,600 & $3,318,000$ & $1,372,000$ & ANL Cost Estimate \\
\hline Performance Review (every 5 years) & 1 & per 5 yrs & 30 & 100,000 & 600,000 & 239,000 & Based upon EA cost \\
\hline TOTAL POST-CLOSURE COSTS & & & & & $15,271,000$ & $6,307,000$ & \\
\hline \multicolumn{8}{|l|}{ PRESENT WORTH COSTS: } \\
\hline Capital costs: & & & & & 150,000 & 150,000 & \\
\hline Annual costs: & & & & & $15,271,000$ & $6,307,000$ & \\
\hline \multirow[t]{3}{*}{ TOTAL COST } & & & & & $15,421,000$ & $6,457,000$ & \\
\hline & & & & Time Frame & 30-year & 100-year & 1,000-year \\
\hline & & & & Present Worth & $6,457,000$ & $7,413,000$ & $7,422,000$ \\
\hline
\end{tabular}




\section{E.6 REFERENCES FOR APPENDIX E}

Delta Research Corporation, 1995, Remedial Action Cost Estimating and Requirements System (RACER) User Manual, Niceville, Fla.

Hood, F., 1997, personal communication from F. Hood (MK-Ferguson, Boise, Idaho) to S. Folga (Argonne National Laboratory, Argonne, Ill.), March 13.

U.S. Army Corps of Engineers, 1989, Computer Aided Cost Engineering Support System: Description and Overview, Office of the Chief of Engineers, May 1.

U.S. Department of Energy, 1990, Cost Estimating Handbook for Environmental Restoration, Environmental Restoration and Waste Management Cost Assessment Team, Rev. 0, Sept.

U.S. Environmental Agency, 1988, Guidance for Conducting Remedial Investigations and Feasibility Studies Under CERCLA, EPA/540/G-89/004, Office of Emergency and Remedial Response, Washington, D.C.

U.S. Environmental Protection Agency, 1993, Revision to OMB A-94, Average Discount Rate for Beneficial Cost Analysis, OSWER Directive 9355.3-20, June. 
APPENDIX F:

DISTRIBUTION COEFFICIENT MEASUREMENTS

IN THE QUARRY RESIDUALS OPERABLE UNIT AREA 


\section{APPENDIX F:}

\section{DISTRIBUTION COEFFICIENT MEASUREMENTS IN THE QUARRY RESIDUALS OPERABLE UNIT AREA}

Uranium migration in the groundwater south of the quarry will be limited to some extent by sorption. Sorption occurs as adsorption, molecular species attached to surface sites, or absorption, molecular species attached to internal sites (e.g., in clays). An overall measure of sorption in realworld situations is the distribution coefficient $\left(K_{d}\right)$. Site-specific $K_{d}$ values were necessary for estimating the remediation times for groundwater cleanup in Chapter 4 . This appendix describes the determination of these site-specific $\mathrm{K}_{\mathbf{d}}$ values for the Quarry Residuals Operable Unit (QROU).

The $\mathrm{K}_{\mathrm{d}}$ is the ratio of the amount of a particular species in soil to the amount of that species dissolved in the groundwater. For the purposes of this feasibility study (FS), the $\mathrm{K}_{\mathrm{d}}$ is the ratio of the uranium concentration in the soil to the concentration of uranium dissolved in the groundwater. The fine-grained alluvium has a higher surface area than the coarse-grained alluvium or the bedrock in the QROU area. Therefore, the fine-grained alluvium is expected to have the highest $\mathrm{K}_{d}$ values since more uranium might be expected to be sorbed, thereby increasing the soil to water ratio.

Soil and water samples were obtained from five locations, as shown in Figure F.1, and reported in the Sampling Plan (DOE 1997). Three sample locations (QRSB-001, -002, and -003) spanned the contaminated area south of the quarry and north of the Femme Osage Slough. Two sample locations (QRSB-004 and -005) were located south of the slough. Samples were obtained at two depths at each location as listed in Table F.1.

$\mathrm{K}_{\mathrm{d}}$ values were estimated using three different approaches. First, with the exception of one sample, all water samples contained suspended solids. The solids were removed from solution and the uranium-238 concentrations in both the solids and the clarified liquid phase were measured, since any uranium species was expected to be in equilibrium between the solid and aqueous phases. Second, separate equilibrations between the soil and water samples were performed, and the resulting uranium-238 concentrations in the solid and liquid phases were measured. Third, the water samples were spiked with uranium-232 as a tracer and allowed to reach equilibrium with the soil samples. The resulting uranium-232 concentrations in the solid and liquid phases were measured. 


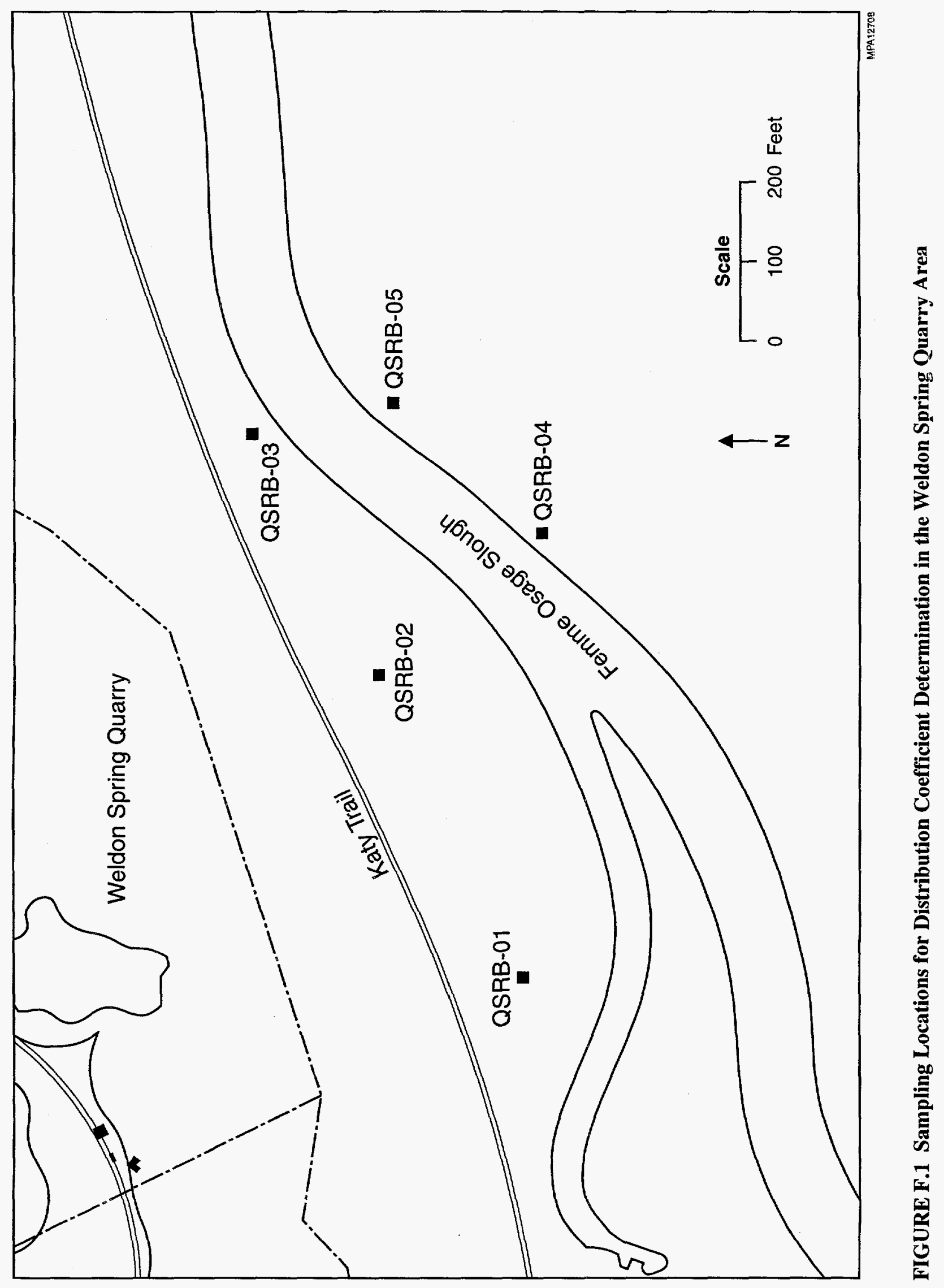


TABLE F.1 Water and Soil Sample Locations for $K_{d}$ Measurements

\begin{tabular}{|c|c|c|c|}
\hline Location & $\begin{array}{c}\text { Sample Interval } \\
\text { No. } 1 \text { (ft bgs) }\end{array}$ & Soil Sample ID & Water Sample ID \\
\hline QRSB-001 & $8-10$ & $\begin{array}{c}\text { SO-197001-01 } \\
\text { SO-197001-01-DU }\end{array}$ & Groundwater not available \\
\hline QRSB-002 & $8-10$ & SO-197002-01 & IS-197002-01 \\
\hline QRSB-003 & $3-5$ & SO-197003-01 & IS-197003-01 \\
\hline QRSB-004 & $14-16$ & SO-197004-01 & Groundwater not available \\
\hline QRSB-005 & $14-16$ & SO-197005-01 & IS-1970059-01 \\
\hline Location & $\begin{array}{l}\text { Sample Interval } \\
\text { No. } 2 \text { (ft bgs) }\end{array}$ & Soil Sample ID & Water Sample ID \\
\hline QRSB-001 & $18-20$ & SO-197001-02 & IS-197001-02 \\
\hline QRSB-002 & $13-15$ & SO-197002-02 & IS-197002-02 \\
\hline QRSB-003 & $10-12$ & SO-197003-02 & $\begin{array}{c}\text { IS-197003-02 } \\
\text { IS-197003-02-DU }\end{array}$ \\
\hline QRSB-004 & $48-50$ & SO-197004-02 & IS-197004-02 \\
\hline QRSB-005 & $48-50$ & SO-197005-02 & IS-1970059-02 \\
\hline
\end{tabular}

\section{F.1 EQUILIBRIUM BETWEEN WATER SAMPLES AND SUSPENDED SOLIDS}

\section{F.1.1 Determination of Uranium Groundwater Concentrations}

The water samples were centrifuged to remove the bulk of the suspended solids. The supernatant solution from each water sample was then filtered through $0.45-\mu \mathrm{m}$ membranes to remove any particulates still suspended in solution. The uranium- 238 concentrations were then determined by using standard radiometric techniques. The measured uranium-238 groundwater concentrations are given in Table F.2. These clarified water samples were also the starting solutions for approaches 2 and 3, as discussed in Sections F.2 and F.3, respectively. 
TABLE F.2 Measured Uranium-238 Concentrations for Water Samples and Suspended Solids

\begin{tabular}{|c|c|c|c|c|c|c|c|c|c|}
\hline \multirow[b]{2}{*}{ Water Sample ID } & \multirow[b]{2}{*}{ Depth $(\mathrm{ft})$} & \multicolumn{2}{|c|}{ Sorbed to Soil } & \multirow[b]{2}{*}{$\begin{array}{c}\text { Water } \\
(\mathrm{pCi} / \mathrm{L})\end{array}$} & \multirow[b]{2}{*}{$\begin{array}{c}+/- \\
(\mathrm{pCi} / \mathrm{L})\end{array}$} & \multicolumn{2}{|c|}{ Residual Soil } & \multirow[b]{2}{*}{$\mathrm{K}_{\mathrm{d}}$} & \multirow[b]{2}{*}{+1} \\
\hline & & $\begin{array}{l}\text { Conc. } \\
(\mathrm{pCi} / \mathrm{g})\end{array}$ & $\begin{array}{c}+/- \\
(\mathrm{pCi} / \mathrm{g}) \\
\end{array}$ & & & $\begin{array}{c}\text { Conc. } \\
\text { (pCi/g) }\end{array}$ & $\begin{array}{c}+/- \\
(\mathrm{pCi} / \mathrm{g}) \\
\end{array}$ & & \\
\hline IS-197001-02 & $18-20$ & 17.5 & 0.4 & 360 & 5 & 0.36 & 0.01 & 49 & 1 \\
\hline IS-197002-01 & $8-10$ & 14.5 & 0.3 & 819 & 11 & 0.41 & 0.01 & 18 & 1 \\
\hline IS-197002-02 & $13-15$ & 9.0 & 0.3 & 523 & 10 & 0.44 & 0.01 & 17 & 1 \\
\hline IS-197003-01 & $3-5$ & 2.5 & 0.1 & 195 & 4 & 0.51 & 0.01 & 13 & 1 \\
\hline IS-197003-02 & $10-12$ & 2.4 & 0.1 & 138 & 4 & 0.45 & 0.01 & 17 & 1 \\
\hline IS-197003-02-DU & $10-12$ & 3.7 & 0.2 & 333 & 8 & 0.40 & 0.01 & 11 & 1 \\
\hline IS-197004-02 & $48-50$ & 0.63 & 0.02 & 0.98 & 0.02 & 0.28 & 0.01 & 643 & 24 \\
\hline IS-1970059-01 & $14-16$ & 0.42 & 0.01 & 2.3 & 0.08 & 0.30 & 0.01 & 183 & 8 \\
\hline IS-1970059-02 & $48-50$ & 0.54 & 0.02 & 0.44 & 0.01 & 0.24 & 0.01 & 1227 & 53 \\
\hline
\end{tabular}




\section{F.1.2 Determination of Uranium Soil Concentrations}

The suspended solids separated from the groundwater samples discussed in Section F.1.1 were dried at $60^{\circ} \mathrm{C}\left(100^{\circ} \mathrm{F}\right)$. A portion of each solid sample was then ashed to eliminate any organic material at $520^{\circ} \mathrm{C}\left(968^{\circ} \mathrm{F}\right)$ for 24 hours. The ashed material was leached three separate times with strong hydrochloric acid $(50 \% \mathrm{HCl})$. The uranium-238 concentration of the composited leach solutions was determined by using standard radiometric techniques. The measured uranium-238 soil concentrations are given in Table F.2. These soil concentrations were assumed to represent the sorbed uranium in equilibrium with the dissolved uranium in the groundwater in the aquifer. The residual $\mathrm{HCl}$-leached solids were then dissolved in a hydrofluoric/nitric acid mixture and the remaining uranium- 238 concentration measured. This final measurement determines the amount of uranium in the soil that is considered to be part of mineral phases that are unavailable for sorption/desorption. These final uranium-238 concentrations are given in Table F.2.

\section{F.2 EQUILIBRIUM BETWEEN FILTERED WATER SAMPLES AND SOIL SAMPLES}

Selected soil samples were allowed to equilibrate with the filtered water samples. Preparation of the filtered water samples is described in Section F.1.1. For each $\mathrm{K}_{\mathrm{d}}$ measurement, approximately $25 \mathrm{~g}$ of soil was mixed with $20 \mathrm{~mL}$ of the water sample. The equilibration was allowed to occur for one month, after which the water and soil concentrations were measured. The results are presented in Table F.3.

\section{F.3 EQUILIBRIUM BETWEEN URANIUM-232 WATER SAMPLES AND SOIL SAMPLES}

Before each equilibration described in Section F.2 was initiated, an aliquot of uranium-232 was added to each water sample. The uranium-232 isotope of uranium, not present in the Weldon Spring area, was used as a tracer to monitor uptake of uranium by the soil samples and provide additional measurements for determining $K_{d}$ values. The results are presented in Table F.4 and provide a direct comparison with the uranium-238 results shown in Table F.3.

\section{F.4 DISCUSSION}

\section{F.4.1 Diffusion Coefficients North of the Femme Osage Slough}

Data from sample locations north of the slough, locations QRSB-001, -002, and -003, suggest an approximate $\mathrm{K}_{\mathrm{d}}$ value from 5 to 50 for use in estimating remediation times for various action alternatives. Of the $16 \mathrm{~K}_{\mathrm{d}}$ values estimated from these locations, only two were higher than 
TABLE F.3 Measured Uranium-238 Concentrations for Water and Soil Samples in Equilibrium

\begin{tabular}{|c|c|c|c|c|c|c|c|c|}
\hline \multirow[b]{2}{*}{ Water Sample ID } & \multirow[b]{2}{*}{ Soil Sample ID } & \multirow[b]{2}{*}{ Depth $(\mathrm{ft})$} & \multicolumn{2}{|c|}{ Sorbed to Soil } & \multirow[b]{2}{*}{$\begin{array}{c}\text { Water } \\
(\mathrm{pCi} / \mathrm{L})\end{array}$} & \multirow[b]{2}{*}{$\begin{array}{c}+/- \\
(\mathrm{pCi} / \mathrm{L}) \\
\end{array}$} & \multirow[b]{2}{*}{$\begin{array}{c}\mathrm{K}_{\mathrm{d}} \\
(\mathrm{mL} / \mathrm{g}) \\
\end{array}$} & \multirow[b]{2}{*}{$\begin{array}{c}+/- \\
(\mathrm{mL} / \mathrm{g}) \\
\end{array}$} \\
\hline & & & $\begin{array}{l}\text { Conc. } \\
\text { (pCi/g) }\end{array}$ & $\begin{array}{c}+/- \\
(\mathrm{pCi} / \mathrm{g})\end{array}$ & & & & \\
\hline IS-197002-01 & SO-197001-01 & $8-10$ & 4.8 & 0.1 & 468 & 23 & 10.2 & 0.5 \\
\hline IS-197001-02 & SO-197001-02 & $18-20$ & 9.9 & 0.2 & 2457 & 116 & 4 & 0.2 \\
\hline IS-197002-02 & SO-197002-02 & $13-15$ & 0.75 & 0.05 & 8.52 & 0.33 & 88 & 5 \\
\hline IS-197003-01 & SO-197003-01 & $3-5$ & 8.1 & 0.2 & 249 & 12 & 33 & 2 \\
\hline IS-197003-02-DU & SO-197003-02 & $10-12$ & 16.2 & 0.4 & 2849 & 134 & 5.7 & 0.4 \\
\hline IS-1970059-01 & SO-197004-01 & $14-16$ & 0.56 & 0.04 & 3.1 & 0.2 & 180 & 13 \\
\hline IS-197004-02 & SO-197004-02 & $48-50$ & 0.12 & 0.02 & 3.16 & 0.2 & 39 & 7 \\
\hline IS-197003-02 & SO-197005-01 & $14-16$ & 0.65 & 0.04 & 17.1 & 1.3 & 38 & 3 \\
\hline
\end{tabular}


50 , as can be seen in Tables F.2 to F.4. These two values, 88 and 224, were both from the same equilibrium experiment (uranium-238 and uranium-232 equilibriums, respectively) involving soil sample SO-197002-02 and water sample SI-197002-02. This deviation may be due to an iron precipitate that was observed to form during the course of this experiment and not in the other equilibrium experiments.

The freshly deposited hydrous iron oxide observed is expected to be more sorbent of uranium than the clay material composing the soil sample. Therefore, the soil concentration increases. Also, to determine the final uranium soil concentration (the amount in/on the soil available for equilibrium with the liquid phase), an $\mathrm{HCl}$ solution is used to leach the uranium from the soil, as discussed in Section F.1.2. Such a method is necessary to remove the available uranium; it is possible, however, that some uranium not available for equilibrium is also removed.

Because leaching of the soil with $\mathrm{HCl}$ can lead to higher nonrepresentative $\mathrm{K}_{\mathrm{d}}$ values, the estimates presented in Tables F.2 and F.3 could be slightly higher than is actually present north of the slough. However, natural uranium mineral phases are generally not dissolved by $\mathrm{HCl}$, unlike sorbed uranium. The use of the uranium-232 tracer introduced into the aqueous phase in the equilibrium experiments helps to serve as a check on the results. Since there was no pre-existing uranium-232 phase present in the soil, any uranium-232 present in the soil at the end of the equilibration period is likely to be in equilibrium with the solution and removable by leaching with an $\mathrm{HCl}$ solution. At the conclusion of the equilibrium experiments, any uranium-232 found as part of the soil phase can be assumed to be participating in the solid/liquid phase equilibrium as represented by the $\mathrm{K}_{\mathrm{d}}$ value. This assumption is expected to be reasonable, since no chemical reactions that would result in precipitation of insoluble species are expected, because the soil and water samples were taken from the same areas and were essentially in equilibrium previously. The only exception is that noted in the preceding paragraph where a precipitate was observed (even though the soil and water samples were from the same location and depth), and a $\mathrm{K}_{\mathrm{d}}$ value of 224 was estimated using the uranium-232 uptake results.

For the region north of the slough, a $\mathrm{K}_{\mathrm{d}}$ value of 5 provides a reasonable approximation for the general area. The two lowest uranium-232 uptake results are both a value of 5 , and the lower value uranium-238 results support this estimate. For samples from locations north of the slough, acid leaching $(\mathrm{HCl})$ during the measurement of uranium soil concentrations is, therefore, expected to be primarily releasing sorbed uranium that is in equilibrium with the aqueous phase. Either uranium not available for sorption/desorption is being released in insignificant quantities compared to the sorbed phase release, or there is no release of this type. 
TABLE F.4 Measured Uranium-232 Concentrations for Water and Soil Samples in Equilibrium

\begin{tabular}{|c|c|c|c|c|c|c|c|c|}
\hline \multirow[b]{2}{*}{ Water Sample ID } & \multirow[b]{2}{*}{ Soil Sample ID } & \multirow[b]{2}{*}{ Depth $(\mathrm{ft})$} & \multicolumn{2}{|c|}{ Sorbed to Soil } & \multirow[b]{2}{*}{$\begin{array}{c}\text { Water } \\
(\mathrm{dpm} / \mathrm{mL})\end{array}$} & \multirow[b]{2}{*}{$\begin{array}{c}+/- \\
(\mathrm{dpm} / \mathrm{mL})\end{array}$} & \multirow[b]{2}{*}{$\begin{array}{c}\mathrm{K}_{\mathrm{d}} \\
(\mathrm{mL} / \mathrm{g})\end{array}$} & \multirow[b]{2}{*}{$\begin{array}{c}+/- \\
(\mathrm{mL} / \mathrm{g})\end{array}$} \\
\hline & & & $\begin{array}{c}\text { Conc. } \\
(\mathrm{dpm} / \mathrm{g})\end{array}$ & $\begin{array}{c}+/- \\
(\mathrm{dpm} / \mathrm{g})\end{array}$ & & & & \\
\hline IS-197002-01 & SO-197001-01 & $8-10$ & 2.44 & 0.14 & 0.29 & 0.01 & 8.6 & 0.5 \\
\hline IS-197001-02 & SO-197001-02 & $18-20$ & 1.3 & 0.09 & 0.24 & 0.01 & 5.4 & 0.3 \\
\hline IS-197002-02 & SO-197002-02 & $13-15$ & 1.64 & 0.1 & 0.0073 & $4 \mathrm{E}-04$ & 224 & 14 \\
\hline IS-197003-01 & SO-197003-01 & $3-5$ & 2.94 & 0.14 & 0.10 & 0.005 & 28 & 1.4 \\
\hline IS-197003-02-DU & SO-197003-02 & $10-12$ & 2.0 & 0.1 & 0.38 & 0.02 & 5.3 & 0.4 \\
\hline IS-1970059-01 & SO-197004-01 & $14-16$ & 2.5 & 0.13 & 0.16 & 0.008 & 16 & 1 \\
\hline IS-197004-02 & SO-197004-02 & $48-50$ & 1.0 & 0.08 & 0.80 & 0.01 & 1.2 & 0.2 \\
\hline IS-197003-02 & SO-197005-01 & $14-16$ & 2.0 & 0.1 & 0.20 & 0.01 & 10 & 0.6 \\
\hline
\end{tabular}




\section{F.4.2 Diffusion Coefficients South of the Femme Osage Slough}

For uranium-238 soil concentration measurements from the samples south of the slough (from locations QRSB-004 and QRSB-005), it appears that the $\mathrm{HCl}$ leaching may be partially removing uranium from the soil that does not participate in natural sorption/desorption reactions. The $\mathrm{K}_{\mathrm{d}}$ values derived from these uranium-238 data (Table F.2) are high (183, 643, and 1,227), compared to those determined for the values north of the slough (approximately 5 to 50 ) and compared to the $K_{d}$ values obtained from the uranium-232 data $(1.2,10$, and 16). The uranium soil and groundwater concentrations at these locations are at background levels. Any small change in either the soil or groundwater concentration is a much greater relative change than in the contaminated areas north of the slough and will have a much greater effect on the $\mathrm{K}_{\mathrm{d}}$ value. Also, the uranium-232-derived $\mathrm{K}_{\mathrm{d}}$ value of 1.2 (in direct contrast to the uranium-238-derived value of 1,227 for the same experiment) corresponds to the sample from the $15-\mathrm{m}$ ( 48 to $50 \mathrm{ft}$ ) level in the coarse-grained alluvium. This value indicates fewer soil sorption sites, which is consistent with the nature of the coarser grains relative to the upper lying fine-grained alluvium.

\section{F.5 REFERENCE}

U.S. Department of Energy, 1997, Sampling Plan for the Feasibility Study for the Quarry Residuals Operable Unit at the Weldon Spring Site, Weldon Spring, Missouri, DOE/OR/21548-699, prepared by MK-Ferguson Company and Jacobs Engineering Group, St. Charles, Mo., for U.S. Department of Energy, Oak Ridge Operations Office, Weldon Spring Site Remedial Action Project, Weldon Spring, Mo., June. 